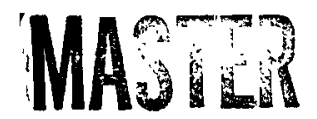

\title{
STANDARD TECHNICAL SPECIFICATIONS FOR COMBUSTION ENGINEERING PRESSURIZED WATER REACTORS
}

Revision of August 1979

Office of Nuclear Reactor Regulation U. S. Nuclear Regulatory Commission 
Available from

National Technical Information Service Springfield, Virginia 22161

Price: Printed Copy $\$ 13.25$; Microfiche $\$ 3.00$ 


\section{DISCLAIMER}

This report was prepared as an account of work sponsored by an agency of the United States Government. Neither the United States Government nor any agency Thereof, nor any of their employees, makes any warranty, express or implied, or assumes any legal liability or responsibility for the accuracy, completeness, or usefulness of any information, apparatus, product, or process disclosed, or represents that its use would not infringe privately owned rights. Reference herein to any specific commercial product, process, or service by trade name, trademark, manufacturer, or otherwise does not necessarily constitute or imply its endorsement, recommendation, or favoring by the United States Government or any agency thereof. The views and opinions of authors expressed herein do not necessarily state or reflect those of the United States Government or any agency thereof. 


\section{DISCLAIMER}

Portions of this document may be illegible in electronic image products. Images are produced from the best available original document. 
NUREG-0212

REVISION 1

\title{
STANDARD TECHNICAL SPECIFICATIONS FOR COMBUSTION ENGINEERING PRESSURIZED WATER REACTORS
}

\author{
Revision of August 1979 \\ Supercedes NUREG-0212, Revision 0
}

Date Published: August 1979

Division of Operating Reactors

Office of Nuclear Reactor Regulation

U. S. Nuclear Regulatory Commission

Washington, D. C. 20555 
FOPEWAPE

The following paragraphs briefly describe the applicability, format and implementation of the Combustion Engineerina Standard Technical Specification package.

\section{APPLICARILITY}

This Standard Technical Specification (STS) has been structured for the broadest possible use on Combustion Engineering plants currently heina reviewed for an Operating License. Two separate and discrete containment specification sections are provided for each of the following containment types: Atmospheric and rual. Cptional specifications are provided for those features and systems which may be included in individual plant designs hut are not aeneric in their scope of application. Alternate specifications are provided in a limited number of cases to cover situations where alternate specification requirements are necessary on a generic hasis because of desian differences. This revision of STS does not typically include requirements which may he added or revised as a result of the NRC staff's further review of the Three Mile Island incident.

\section{FORMAT}

The format of the STS addresses the categories required hy 10 CFR 50 and consists of six sections covering the areas of: Definitions, Safety Limits and Limiting Safety System Settinas, Limiting Conditions for Operation, Surveillance Requirements, Design Features, and Administrative Controls. The Limiting Conditions for Operation and Surveillance Pequirements (Sections $3 \&_{1}$ 4) are presented in a combined format with each LCO appearing at the top of the paqe followed immediately by the applicable surveillance Requirements. The combined Section $3 / 4$ is further subdivided into ten subsections coverina the areas of:

1. Reactivity Control,

2. Power Distribution,

3. Instrumentation,

4. Reactor Coolant System,

5. Emeraency Core Coolinạ System,

6. Containment Systems,

7. Plant System,

8. Electrical Power Systems, 
a. Refueling nperations, and

10. Special Test Exceptions.

The values of those parameters and variables which may vary hecause of plant design anpear as either blanks or parenthesized numbers throughout the STS. The actual value for each parameter will he nrovided hv individual applicants as appropriate for their plants. The values in parentheses are for illustration only.

IMPLEMENTATION

The implementation of the STS on an individual license anplication will nroceed in three phases. The major steps within each phase are indicated below.

Phase I

The applicant should:

1. Obtain conies of the STS from the NFC.

2. Select the appropriate containment specification section and set aside the non-applicable containment sections and related hases.

3. Identify and mark those specifications not required hecause of plant design or other factors. Specifications within this catecory should be retained in position within the document packane for later review and discussion.

4. Identify those areas where specifications are required hut are not provided in the STS.

5. Provide the applicahle values of the parameters and variahles identified by hlanks or parentheses in the STS. This information must be consistent with the SAR and other sunportina documents.

6. Provide the fiaures, araphs and other information reauired to complete the sTS document packane.

Phase I I

1. The Commission staff will review the information provided in the marked up STS document package resulting from the Phase I preparation.

2. An applicant/staff meeting will he held to resolve noted differences of position and other related comments from the applicant, vendor and A.E. 


\section{Phase III}

1. The Commission will nrovide a Proof and Peview edition of the technical specification for final review hy all parties hased upon the resolution of comments and nositions in Phase II.

2. Final comments and corrections will be incorporated into the document as receiver.

3. The Technical Specifications will he issued by the rommission as Appendix "A" of the Operating License. 
1.0 DEFINITINNS

DEFINED TERMS....................................... 1-1

THERMAL POWER.................................. 1

RATED THERMAL POWER............................ 1-1

OPERATIONAL MODE-MODE........................... $1-1$

ACTION.......................................... 1

OPERABLE - OPERARILITY.......................... $1-1$

REPORTABLE OCCURENCE............................ 1-1

CONTAINMENT INTEGRITY........................... 1-2

CHANNEL CALIRRATION............................. $1-2$

CHANNEL CHECK.................................... 1-2

CHANMEL FUNCTIONAL TEST.......................... 1-3

CORE ALTERATION................................. 1-3

SHUTDOWN MARGIN................................ 1-3

IDENT IFIED LEAKAGE............................ 1-3

UNIDENTIFIED LEAKAGE............................ 1-4

PRESSURE BOUNDARY LEAKAGE........................ 1-4

CONTROLLED LEAKAGE.............................. 1-4

AXIMUTHAL POWER TILT............................. 1-4

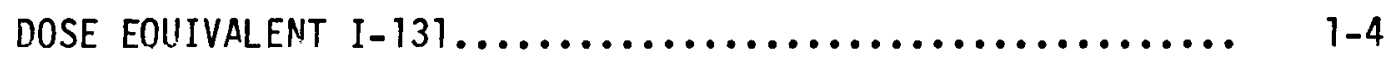

STAGGERED TEST BASIS............................ $1-4$

FREOUENCY NOTATION............................... $1-5$

REACTOR PROTECTION SYSTEM RESPONSE TIME............... $1-5$

ENGINEERED SAFETY FEATURE PESPDNSE TIME................ 1-5

AXIAL SHAPE INDEX.............................. 1-5

PHYSICS TESTS................................. 1-5

$\bar{E}$-AVFRAGE DISINTEGRATION ENERGY...................... 1-5

SHIELD RUILDING INTEGRITY........................ 1-6

SOFTVIARE...................................... I-6

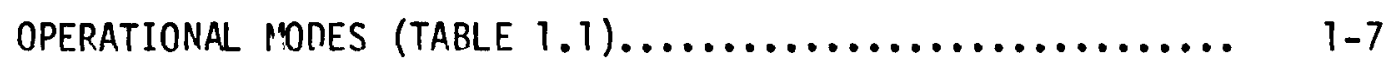

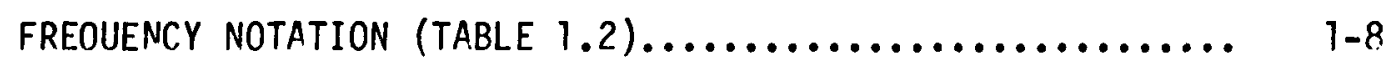


SECTION

PAGE

2.1 SAFETY LIMITS

2.1 .1 .1 DNBR............. $2-1$

2.1.1.2 PEAK LINEAR HEAT RATE.................. 2-1

2.1.2 REACTOR COOLANT SYSTEM PRESSURE............... 2-1

2.2 LIMITING SAFETY SYSTEM SETTINGS

2.2. I REACTOR TRIP SETPOINTS..................... 2-4

SECTION

PAGE

2.1 SAFETY LIMITS

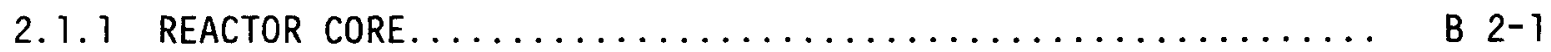

2.1.2 REACTOR COOLANT SYSTEM PRESSURE................. B $2-2$

2.2 LIMITING SAFETY SYSTEM SETTINGS

2.2.1 REACTOR TRIP SETPOINTS...................... B 2-2 
INDEX

LIMITING CONDITIONS FOR OPERATION AND SURVEILLANCE REQUIREMENTS

SECTION

PAGE

3/4.0 APPLICABILITY.

$3 / 40-1$

3/4. 1 REACTIVITY CONTROL SYSTEMS

3/4.1.1 BORATION CONTROL

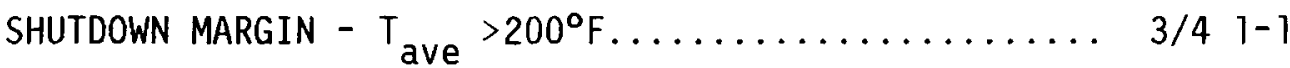

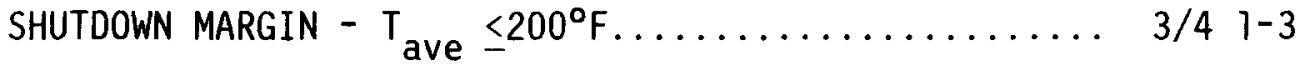

MODERATOR TEMPERATURE COEFFICIENT............... $3 / 4$ 1-4

MINIMUM TEMPERATURE FOR CRITICALITY............. $3 / 4$ 1-5

3/4.1.2 BORATION SYSTEMS

FLOW PATHS - SHUTDOWN........................ $3 / 4$ 1-6

FLOW PATHS - OPERATING.................... 3/4 1-7

CHARGING PUMP - SHUTDOWN.................... $3 / 41-8$

CHARGING PUMPS - OPERATING.................. $3 / 41-9$

BORIC ACID MAKEUP PUMPS - SHUTDOWN.............. 3/4 1-10

BORIC ACID MAKEUP PUMPS - OPERATING.............. 3/4 1-11

BORATED WATER SOURCE - SHUTDOWN................ $3 / 41-12$

BORATED WATER SOURCES - OPERATING.............. 3/4 1-14

3/4.1.3 MOVABLE CONTROL ASSEMBLIES

CEA POSITION............................. $3 / 4 \quad 1-15$

POSITION INDICATOR CHANNELS-OPERATING............. 3/4 1-18

POSITION INDICATOR CHANNELS-SHUTDOWN............. $3 / 4 \quad 1-19$

CEA DROP TIME............................... 3/4 1-20

SHUTDOWN CEA INSERTION LIMIT................. $3 / 4$ 1-21

REGULATING CEA INSERTION LIMITS $\ldots \ldots \ldots \ldots \ldots \ldots \ldots .3 / 41-22$

PART LENGTH CEA INSERTION LIMITS............... $3 / 4$ 1-25

PART LENGTH CEA INSERTION LIMITS (ALTERNATE)....... $3 / 4 \quad 1-26$ 
SECTION

PAGE

$3 / 4.2$ POWER DISTRIBUTION LIMITS

3/4.2. 1 LINEAR HEAT RATE.................. 3/4 2-1

3/4.2.2 RADIAL PEAKING FACTORS.................... 3/4 2-3

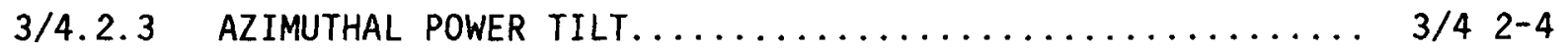

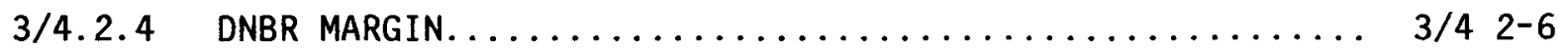

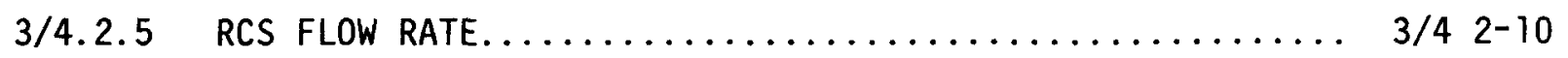

3/4.2.6 CORE AVERAge COOLANT TEMPERATURE.............. $3 / 42-11$

3/4.3 INSTRUMENTATION

3/4.3.1 REACTOR PROTECTIVE INSTRUMENTATION............. 3/4 3-1

3/4.3.2 ENGINEERED SAFETY FEATURE ACTUATION SYSTEM
INSTRUMENTATION. $\ldots \ldots \ldots \ldots \ldots \ldots \ldots \ldots \ldots \ldots \ldots \ldots \ldots \ldots \ldots \ldots \ldots \ldots$
$3 / 4 \quad 3-12$

3/4.3.3 MONITORING INSTRUMENTATION

RADIATION MONITORING INSTRUMENTATION. . . . . . . . . 3/4 3-27

INCORE DETECTORS........................ 3/4 3-31

SEISMIC INSTRUMENTATION................... 3/4 3-32

METEOROLOGICAL INSTRUMENTATION. ............ 3/4 3-35

REMOTE SHUTDOWN INSTRUMENTATION............. 3/4 3-38

POST-ACCIDENT INSTRUMENTATION.............. 3/4 3-41

CHLORINE DETECTION SYSTEMS.................. 3/4 3-44

FIRE DETECTION INSTRUMENTATION.............. 3/4 3-45

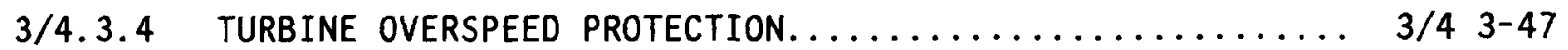

$3 / 4.4$ REACTOR COOLANT SYSTEM

3/4.4.1 REACTOR COOLANT LOOPS................... 3/4 4-1

3/4.4.2 SAFETY VALVES - SHUTDOWN................. 3/4 4-3

3/4.4.3 SAFETY VALVES - OPERATING................. 3/4 4-4 
SECTION

PAGE

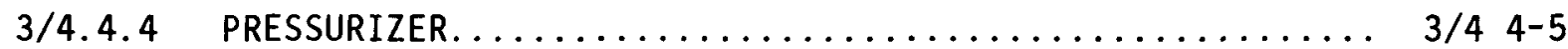

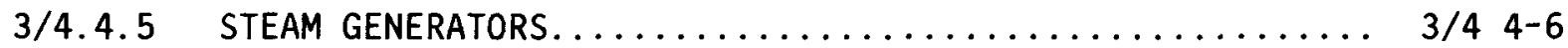

3/4.4.6 REACTOR COOLANT SYSTEM LEAKAGE

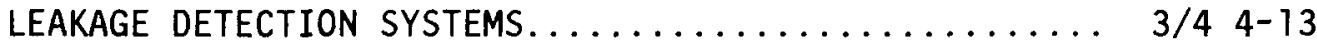

OPERATIONAL LEAKAGE.................... 3/4 4-14

3/4.4.7 CHEMISTRY........................... 3/4 4-16

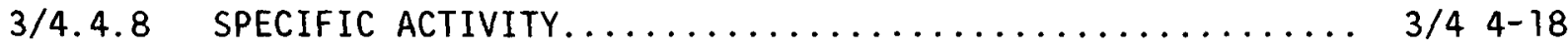

3/4.4.9 PRESSURE/TEMPERATURE LIMITS

REACTOR COOLANT SYSTEM.................. 3/4 4-23

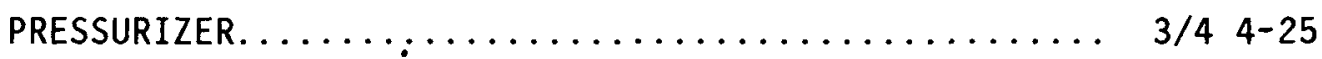

OVERPRESSURE PROTECTION SYSTEMS............. 3/4 4-26

3/4.4.10 STRUCTURAL INTEGRITY

ASME CODE CLASS 1,2 AND 3 COMPONENTS........... 3/4 4-28

$3 / 4.5$ EMERGENCY CORE COOLING SYSTEMS (ECCS)

3/4.5.1 SAFETY INJECTION TANKS .................... 3/4 5-1

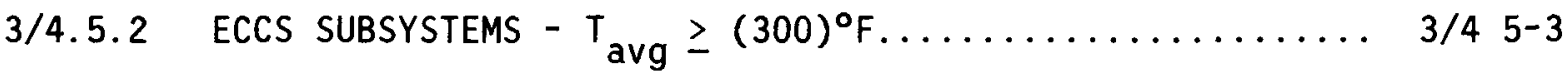

$3 / 4.5 .3$ ECCS SUBSYSTEMS - $\mathrm{T}_{\text {avg }}<(300)^{\circ} \mathrm{F} \ldots \ldots \ldots \ldots \ldots \ldots \ldots \ldots \ldots$ 3/4 5-7

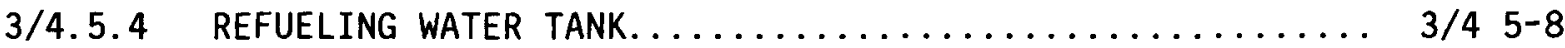



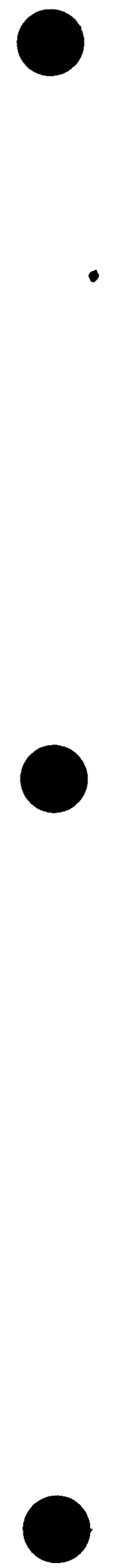
SECTION

PAGE

\section{CE - ATMOSPHERIC TYPE CONTAINMENT}

3/4.6 CONTAINMENT SYSTEMS

3/4.6.1 PRIMARY CONTAINMENT

CONTAINMENT INTEGRITY...................... $3 / 46-1 \mathrm{~F}$

CONTAINMENT LEAKAGE........................ $3 / 46-2 \mathrm{~F}$

CONTAINMENT AIR LOCKS....................... 3/4 6-5F

CONTAINMENT ISOLATION VALVE AND CHANNEL WELD

PRESSURIZATION SYSTEMS...................... $3 / 4 \quad 6-7 \mathrm{~F}$

INTERNAL PRESSURE............................ $3 / 46-8 \mathrm{~F}$

AIR TEMPERATURE............................ $3 / 46-9 \mathrm{~F}$

CONTAINMENT STRUCTURAL INTEGRITY............. $3 / 46-10 \mathrm{~F}$

CONTAINMENT VENTILATION SYSTEM................ $3 / 46-17 \mathrm{~F}$

3/4.6.2 DEPRESSURIZATION AND COOLING SYSTEMS

CONTAINMENT SPRAY SYSTEM.................... $3 / 4$ 6-18F

SPRAY ADDITIVE SYSTEM..................... $3 / 46-22 \mathrm{~F}$

CONTAINMENT COOLING SYSTEM.................. $3 / 46-24 \mathrm{~F}$

3/4.6.3 IODINE CLEANUP SYSTEM........................ $3 / 46-26 \mathrm{~F}$

3/4.6.4 CONTAINMENT ISOLATION VALVES.................... $3 / 46-28 \mathrm{~F}$

3/4.6.5 COMBUSTIBLE GAS CONTROL

HYDROGEN ANALYZERS........................... 3/4 6-31F

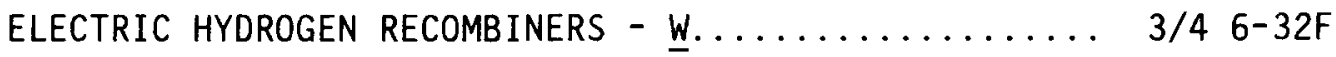

HYDROGEN PURGE CLEANUP SYSTEM................ $3 / 46-33 \mathrm{~F}$

HYDROGEN MIXING SYSTEM.................... $3 / 46-35 \mathrm{~F}$

3/4.6.6 PENETRATION ROOM EXHAUST AIR CLEANUP SYSTEM.......... $3 / 46$ 6-36F

$3 / 4.6 .7$ VACUUM RELIEF VALVES......................... $3 / 46-38 \mathrm{~F}$

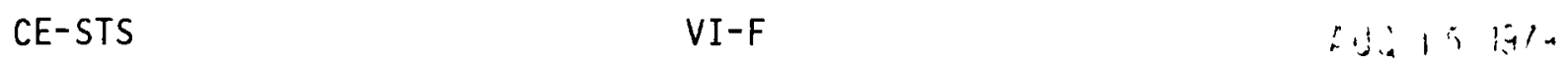


INDEX

LIMITING CONDITIONS FOR OPERATION AND SURVEILLANCE REQUIREMENTS

SECTION

PAGE

\section{CE - DUAL TYPE CONTAINMENT}

$3 / 4.6$ CONTAINMENT SYSTEMS

3/4.6.1 PRIMARY CONTAINMENT

CONTAINMENT INTEGRITY................... 3/4 6-1H

CONTAINMENT LEAKAGE...................... 3/4 6-2H

CONTAINMENT AIR LOCKS.................. 3/4 6-6H

CONTAINMENT ISOLATION VALVE AND CHANNEL WELD

PRESSURIZATION SYSTEMS................. $3 / 46-8 \mathrm{H}$

INTERNAL PRESSURE.................. $3 / 46-9 \mathrm{H}$

AIR TEMPERATURE......................... 3/4 6-10H

CONTAINMENT VESSEL STRUCTURAL INTEGRITY.......... $3 / 46-11 \mathrm{H}$

CONTAINMENT VENTILATION SYSTEM............... 3/4 6-12H

3/4.6.2 DEPRESSURIZATION AND COOLING SYSTEMS

CONTAINMENT SPRAY SYSTEM................ 3/4 6-13H

SPRAY ADDITIVE SYSTEM.................. 3/4 6-17H

CONTAINMENT COOLING SYSTEM................ 3/4 6-19H

3/4.6.3 IODINE CLEANUP SYSTEM..................... 3/4 6-23H

$3 / 4.6 .4$ CONTAINMENT ISOLATION VALVES................ $3 / 46-25 \mathrm{H}$

3/4.6.5 COMBUSTIBLE GAS CONTROL

HYDROGEN ANALYZERS................... $3 / 4$ 6-28H

ELECTRIC HYDROGEN RECOMBINERS - $\underline{W} \ldots \ldots \ldots \ldots \ldots \ldots \ldots . \ldots 3 / 46-29 \mathrm{H}$

HYDROGEN PURGE CLEANUP SYSTEM.............. 3/4 6-30H

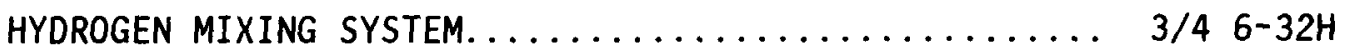

3/4.6.6 PENETRATION ROOM EXHAUST AIR CLEANUP SYSTEM......... $3 / 46-33 \mathrm{H}$

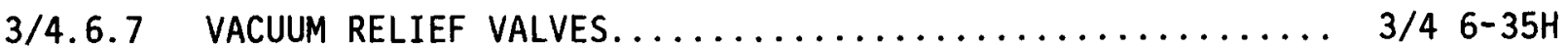

3/4.6.8 SECONDARY CONTAINMENT

SHIELD BUILDING AIR CLEANUP SYSTEM............ $3 / 46-36 \mathrm{H}$

SHIELD BUILDING INTEGRITY................ $3 / 46-39 H$

SHIELD BUILDING STRUCTURAL INTEGRITY.......... $3 / 46-40 \mathrm{H}$ 
SECTION"

$3 / 4.7$ PLANT SYSTEMS

3/4.7.1 TURBINE CVCLE

SAFETY VALVES........................... 3/4 7-1

AUXILIARY FEERWATER SYSTEM.................. 3/4 7-5

COMNENSATE STRRAGE TANK..................... 3/4 7-7

ACTIVITY.................................. 3/4 7-8

MAIN STEAM LINE ISNLATION VALVES............... $3 / 4$ 7-10

3/4.7.2 STEAM GFNFPATOP PR.ESSURE/TEMPFPATIIPF LIMITATION....... 3/4 7-11

$3 / 4.7 .3$ COMPONENT CONLING WATER SYSTEM.................. 3/4 7-12

3/4.7.4 SERVICE WATER SYSTEM........................ 3/4 7-13

$3 / 4.7 .5$ IILTIMATE HEAT SINK.......................... 3/4 7-14

$3 / 4.7 .6$ FLOOD PPOTECTION............................. 3/4 7-15

3/4.7.7 CONTROL RCOM EMEPGENCY AIR CLEANUP SYSTEM........... 3/4 7-16

$3 / 4.7 .8$ ECCS PIMP ROOM EXHAUST AIR CLFANIP SYSTFM........... 3/4 7-19

$3 / 4.7 .9$ HYDRAUL IC SNURBERS....................... 3/4 7-2?

$3 / 4.7 .10$ SEALED SOUR.CE CONTAMINATION.................... 3/4 7-26

3/4.7.11 FIPE SIIPPRESSION SYSTEMS

FIRE SIIPPRESSION WATER SYSTEM................ 3/4 7-28

SPRAY AND/RR SPRINKLER SYSTEMS............... 3/4 7-32

LOW PRESSURE CO, SYSTEMS.................... 3/4 7-34

HIGH PRESSIJRE $\mathrm{CO}_{2}$ SYSTEMS................... 3/4 7-35

HALON SYSTEMS.............................. 3/4 7-36

FIRE HOSE STATIONS......................... 3/4 7-37

YARD FIRE HYMRANTS ANC HYMRANT HOSE HOUSES........ 3/4 7-39

3/4.7.12 FIRE RAPRIER PENETRATIONS...................... 3/4 7-41

$3 / 47.13$ AREA TEMPERATURE MONITORING.................. 3/4 7-42

$3 / 4.8$ ELECTRICAL POWER SYSTEMS

$3 / 4.8 .1$ A.C. SOURCES

OPERATING.............................. $3 / 4$ 8-1

SHUTDOWN................................. $3 / 48-8$ 
3/4.8.2 ONSITE POWER DISTRIBUTION SYSTEMS

A.C. DistRIBUTION - OPERATING.............. 3/4 8-9

A.C. DISTRIBUTION - SHUTDOWN................ 3/4 8-10

D.C. DISTRIBUTION - OPERATING............... 3/4 8-11

D.C. DISTRIBUTION - SHUTDOWN.............. 3/4 8-13

3/4.8.3 ELECTRICAL EQUIPMENT PROTECTION DEVICES

CONTAINMENT PENETRATION CONDUCTOR OVERCURRENT PROTECTIVE DEVICES...................... $3 / 48-14$

MOTOR-OPERATED VALVES THERMAL OVERLOAD PROTECTION AND $/ O R$ BYPASS DEVICES.................. 3/4 8-17

$3 / 4.9$ REFUELING OPERATIONS

3/4.9.1 BORON CONCENTRATION...................... 3/4 9-1

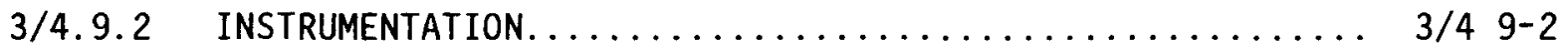

3/4.9.3 DECAY TIME........................... 3/4 9-3

3/4.9.4 CONTAINMENT BUILDING PENETRATIONS................ 3/4 9-4

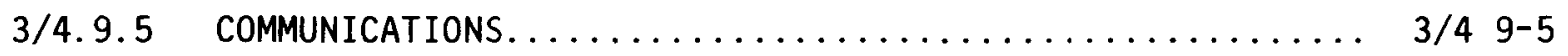

3/4.9.6 MANIPULATOR CRANE OPERABILITY................. 3/4 9-6

3/4.9.7 CRANE TRAVEL - SPENT FUEL STORAGE POOL BUILDING........ 3/4 9-7

3/4.9.8 COOLANT CIRCULATION........................ 3/4 9-8

3/4.9.9 CONTAINMENT PURGE VALVE ISOLATION SYSTEM........... 3/4 9-9

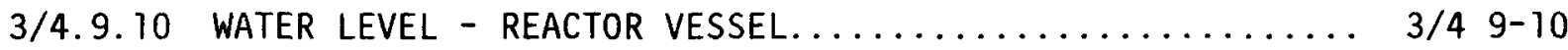

3/4.9.11 WATER LEVEL - STORAGE POOL.................. 3/4 9-11

3/4.9.12 STORAGE POOL AIR CLEANUP SYSTEM................ 3/4 9-12

\section{3/4.10 SPECIAL TEST EXCEPTIONS}

$3 / 4.10 .1$ SHUTDOWN MARGIN.......................... 3/4 10-1

GROUP HEIGHT, INSERTION AND
POWER DISTRIBUTION LIMITS $\ldots \ldots \ldots \ldots \ldots \ldots \ldots \ldots \ldots \ldots \ldots .3 / 410-2$

$3 / 4.10 .3$ REACTOR COOLANT LOOPS..................... 3/4 10-3

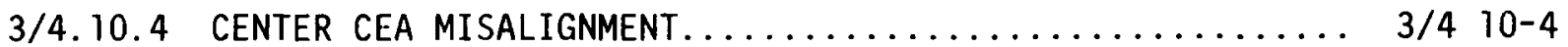


SECTION

PAGE

3/4.0 APPLICABILITY.

B $3 / 40-1$

3/4.1 REACTIVITY CONTROL SYSTEMS

3/4.1.1 BORATION CONTROL.......................... B $3 / 41^{1-1}$

3/4.1.2 BORATION SYSTEMS........................... B $3 / 4$ 1-2

$3 / 4.1 .3$ MOVABLE CONTROL ASSEMBLIES.................. B $3 / 4$ 1-3

$3 / 4.2$ POWER DISTRIBUTION LIMITS

3/4.2.1 LINEAR HEAT RATE.............................. B $3 / 4$ 2-1

3/4.2.2 RADIAL PEAKING FACTORS....................... B $3 / 42-2$

3/4.2.3 AZIMUTHAL POWER TILT....................... B $3 / 42-2$

3/4.2.4 DNBR MARGIN................................. B $3 / 42-4$

3/4.2.5 RCS FLOW RATE.............................. B $3 / 4$ 2-4

3/4.2.6 CORE AVERAGE COOLANT TEMPERATURE................ B $3 / 4$ 2-4

3/4.3 INSTRUMENTATION

3/4.3.1 and 3/4.3.2 REACTOR PROTECTIVE and ENGINEERED SAFETY FEATURES INSTRUMENTATION............................ B $3 / 4$ 3-1

3/4.3.3 MONITORING INSTRUMENTATION..................... B

3/4.3.4 TURBINE OVERSPEED PROTECTION................... B $3 / 4$ 3-3 


\section{INDEX}

BASES

SECTION

PAGE

$3 / 4.4$ REACTOR COOLANT SYSTEM

3/4.4.1 REACTOR COOLANT LOOPS.................. B 3/4 4-1

$3 / 4.4 .2$ and $3 / 4.4 .3$ SAFETY VALVES................ B 3/4 4-1

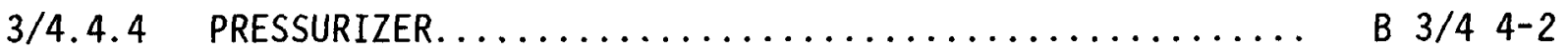

3/4.4.5 STEAM GENERATORS...................... B $3 / 44-2$

3/4.4.6 REACTOR COOLANT SYSTEM LEAKAGE............... B 3/4 4-3

3/4.4.7 CHEMISTRY.......................... B 3/4 4-4

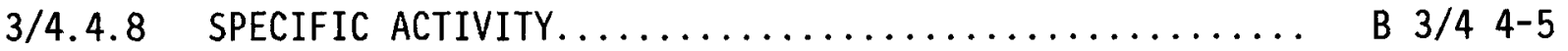

3/4.4.9 PRESSURE/TEMPERATURE LIMITS................ B 3/4 4-6

3/4.4.10 STRUCTURAL INTEGRITY.................... B 3/4 4-10

3/4.5 EMERGENCY CORE COOLING SYSTEMS (ECCS)

3/4.5.1 SAFETY INJECTION TANKS................... B 3/4 5-1

$3 / 4.5 .2$ and $3 / 4.5 .3$ ECCS SUBSYSTEMS................ B 3/4 5-1

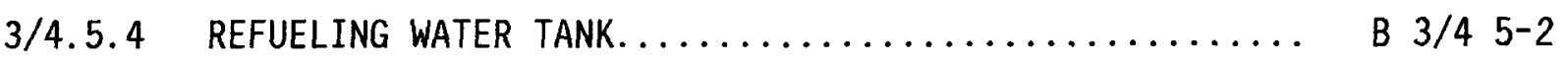




\section{INDEX}

BASES

\section{CE-ATPASPHERIC TYPF CONTAINMENT}

SECTION

PAGF

3/4.6 CONTAINMENT SYSTEMS

3/4.6.1 PRIMARY CONTAINMENT.

R $3 / 4 \quad 6-1 F$

3/4.6.2 DEPRESSURIZATION AND COOLING SYSTEMS.

B $3 / 4 \quad 6-3 F$

3/4.6.3 IODINE CLEANUP SYSTEM.

R $3 / 4$ 6-4F

3/4.6.4 CONTAINMENT ISOLATION VALVES.

R $3 / 4 \quad 6-5 F$

$3 / 4.6 .5$

COMBIISTIRLE. GAS CONTROL

B $3 / 4 \quad 6-5 F$

3/4.6.6 PENETRATION ROOM EXHAUST AIR CLEANUP SYSTEM.

R $3 / 4 \quad 6-5 \mathrm{~F}$

3/4.6.7 VACIUM RELIEF VALVF.S.

R $3 / 4 \quad 6-5 F$ 


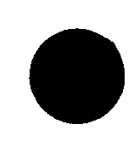

$\bullet$

0

0 


\section{CE - IUAL TYPE CONTAIMMENT}

SECTION!

PAGE

$3 / 4.6$ CONTAINMENT SYSTEMS

3/4.6.1 PRIMARY CONTAINMENT...................... R 3/4 6-1H

$3 / 4.6 .2$ DEPRESSURIZATION AND CNOLING SYSTEMS.............. B 3/4 6-2H

3/4.6.3 IODINE CLEANIIP SYSTEMS..................... R 3/4 6-4H

$3 / 4.6 .4$ CONTAINMENT ISOLATION VALVFS................. B $3 / 46-4 H$

3/4.6.5 COMRIISTIRLE RAS CONTROL................... R $3 / 46-5 \mathrm{H}$

3/4.6.6 PENETRATION POOM EXHAIIST AIR CLEANIIP SYSTEM......... R $3 / 4$ 6-5H

$3 / 4.5 .7$ VACIIIM RELIEF VALVFs..................... R $3 / 46-5 H$

$3 / 4.6 .8$ SECONMARY CONTAINMENT..................... R 3/4 6-6H 


\section{$3 / 4.7$ PLANT SYSTEMS}

3/4.7.1 TURBINE CYCLE................... B 3/4 7-1

3/4.7.2 STEAM GENERATOR PRESSURE/TEMPERATURE LIMITATION...... B $3 / 4$ 7-3

3/4.7.3 COMPONENT COOLING WATER SYSTEM.............. B 3/4 $7-3$

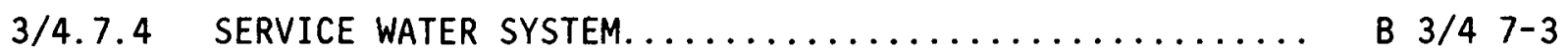

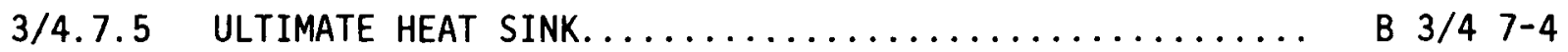

3/4.7.6 FLOOD PROTECTION...................... B 3/4 7-4

3/4.7.7 CONTROL ROOM EMERGENCY AIR CLEANUP SYSTEM......... B 3/4 7-4

3/4.7.8 ECCS PUMP ROOM EXHAUST AIR CLEANUP SYSTEM......... B 3/4 7-4

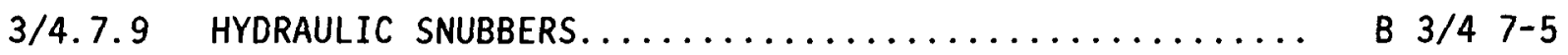

3/4.7.10 SEALED SOURCE CONTAMINATION................ B 3/4 7-5

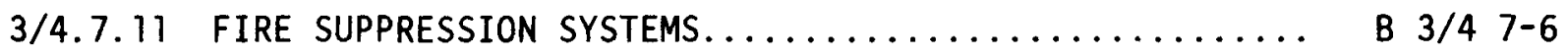

3/4.7.12 FIRE BARRIER PENETRATIONS................. B 3/4 7-6

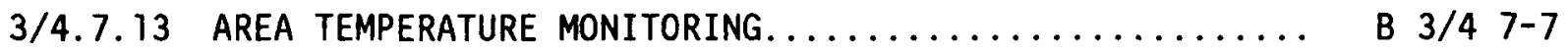

3/4.8 ELECTRICAL POWER SYSTEMS

3/4.8.1 and 3/4.8.2 A.C. SOURCES and

ONSITE POWER DISTRIBUTION SYSTEMS.......... B $3 / 4$ 8- 1

3/4.8.3 ELECTRICAL EQUIPMENT PROTECTIVE DEVICES.......... B $3 / 4$ 8-1

3/4.9 REFUELING OPERATIONS

3/4.9.1 BORON CONCENTRATION

B $3 / 4$ 9-1

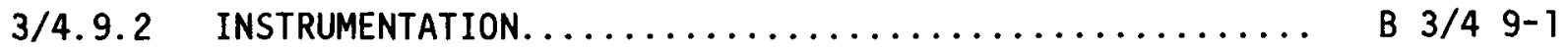

3/4.9.3 DECAY TIME......................... B 3/4 9-1

3/4.9.4 CONTAinment PEnetrations................... B 3/4 9-1

3/4.9.5 COMMUNICATIONS....................... B $3 / 4$ 9-1 
SECTION

PAGE

3/4.9.6 MANIPULATOR CRANE OPERABILITY.

B $3 / 49-2$

3/4.9.7 CRANE TRAVEL - SPENT FUEL STORAGE BUILDING.........

B $3 / 49-2$

3/4.9.8 COOLANT CIRCULATION.

B $3 / 49-2$

3/4.9.9 CONTAINMENT PURGE VALVE ISOLATION SYSTEM.

B $3 / 49-2$

3/4.9.10 and 3/4.9.11 WATER LEVEL - REACTOR VESSEL AND STORAGE POOL

B $3 / 49-3$

3/4.9.12 STORAGE POOL AIR CLEANUP SYSTEM..............

B $3 / 49-3$

3/4.10 SPECIAL TEST EXCEPTIONS

3/4.10.1 SHUTDOWN MARGIN....................... B 3/4 10-1

3/4.10.2 GROUP HEIGHT, INSERTION AND

POWER DISTRIBUTION LIMITS................. B $3 / 410-1$

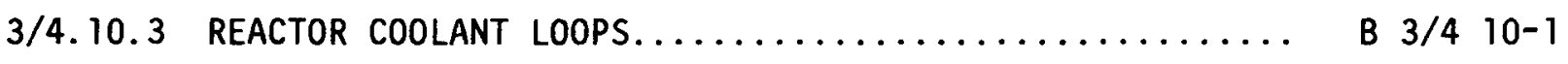

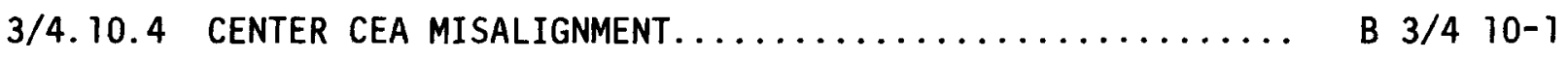


$\underline{\text { SECTION }}$

PAGE

5.1 SITE

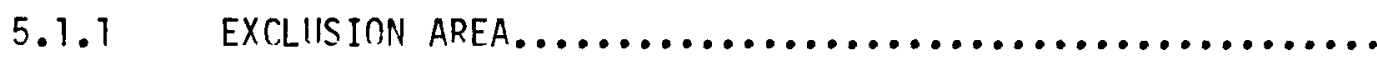

$5-1$

5.1.2 LOH POPULATION ZONE..

$5-1$

5.2 CONTAINMENT

5.2.1 CONFIGUPATION................................. $5-1$

5.2.2 DESIGN PRESSURE AND TEMPERATURE................. $5-1$

5.3 REACTOR CORE

5.3 .1 FUEL ASSFMBLIES.............................. $5-4$

5.3 .2 CONTROL ELEMENT ASSEMBLIES..................... $5-4$

5.4 REACTOR COOLANT SYSTEM

5.4 .1 DESIGM PRESSUIRE AND TEMPERATIURE................ $5-4$

5.4.2 VחLUME..................................... $5-5$

5.5 METEORLOGICAL TOWEP LOCATINN....................... $5-5$

5.6 FUEL STORAGE

$5.6 .1 \quad$ CRITICALITY............................... $5-5$

5.6 .2 DRAINAGE................................ $5-5$

$5.6 .3 \quad$ CAPACITY................................. $5-5$

5.7 COMPONENT CYCLIC OR TRANSIENT LIMIT.................. $5-5$ 
SECTION

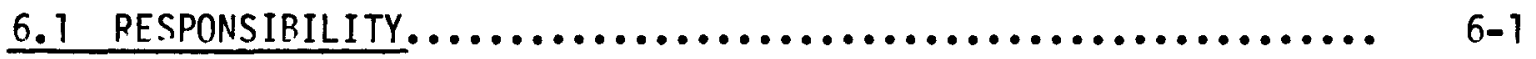

6.2 ORGANITATION

$6.2 .1 \quad$ OFFSITE................................ $6-1$

$6.2 .2 \quad$ INIT STAFF.............................. 6 .

6.3 UNIT STAFF OUALIFICATIONS....................... 6 .

6.4 TRAINING................................... $6-5$

6.5 REVIEW AND AUDIT

6.5.1 UNIT REVIEW GROUP

FUNCTION.................................... $6-5$

COMPOSITION.............................. 6-6

ALTERNATES................................... $6-6$

MEETING FREQUIENCY.......................... $6-6$

OUORUP.................................. $6-6$

RESPONSIBILITIES. .......................... $6-6$

AUTHORITY............................... 6-...

RECORDS................................ $6-7$

6.5.2 COMPANY NUCLEAR REVIEW AND AUDIT GROIP

FUNCTION. ................................ 6-8

COMPOSITION............................... $6-8$

ALTERNATES............................... 6-8

CONSULTANTS............................. 6-8

MEETING FREQUENCY.......................... $6-9$

QUORIM................................... 6-... 
SECTION

PAGE

REVIEW................................... $6-9$

AUDITS.................................. $6-10$

AUTHORITY................................. $6-10$

RECORDS................................ $6-11$

6.6 REPORTABLE OCCURRENCE ACTION...................... $6-11$

6.7 SAFETY LIMIT VIOLATION........................... $6-11$

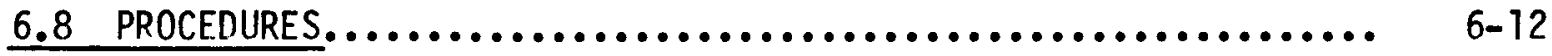

6.9 REPORTING REOUIREMENTS

6.9.1 ROUTINE AND REPORTABLE OCCURRENCES

STARTUP PEPORT............................ $6-12$

ANNUAL REPORT.............................. $6-13$

MONTHLY OPERATING REPORT..................... $6-14$

REPORTABLE OCCURRENCES........................ $6-14$

PROMPT NOTIFICATION WITH WRITTEN FOLLOWUP.......... $6-14$

THIRTY DAY WRITTEN REPORTS..................... $6-15$

6.9.2 SPECIAL REPORTS............................ $6-16$

6.10 RECORD RETENTION................................. $6-16$

6.11 RADIATION PROTECTION PROGRAM..................... $6-18$

6.12 HIGH RADIATION AREA $. . \ldots \ldots \ldots \ldots \ldots \ldots \ldots \ldots \ldots \ldots \ldots \ldots \ldots, 6,18$ 
DEFINED TERMS

1.1 The DEFINED TERMS of this section appear in capitalized type and are applicable throughout these Technical Specifications.

THERMAL POWEP

1.2 THERMAL POWER shall be the total reactor core heat transfer rate to the reactor coolant.

RATEN THERMAL POWER

1.3 RATED THERMAL POWER shall be a total reactor core heat transfer rate to the reactor coolant of _. MUt.

OPERATIONAL MODE - MODE

1.4 An OPERATIONAL MODE (i.e. MODE) shall correspond to any one inclusive combination of core reactivity condition, power level and average reactor coolant temperature specified in Table 1.1.

ACTION

1.5 ACTION shall be those additional requirements specified as corollary statements to each specification and shall be part of the specifications.

OPERABLE - OPERABILITY

1.6 A system, subsystem, train, component or device shall be OPERABLE or have OPERABILITY when it is capable of performing its specified function(s). Implicit in this definition shall be the assumption that all necessary attendant instrumentation, controls, normal and emergency electrical power sources, cooling or seal water, lubrication or other auxiliary equipment that are required for the system, subsystem, train, component or device to perform its function(s) are also capable of performing their related support function(s).

\section{REPORTABLE OCCURRENCE}

1.7 A REPORTABLE OCCURRENCE shall be any of those conditions specified in Specifications 6.9.1.8 and 6.9.1.9. 


\section{CONTAINMENT INTEGRITY}

\subsection{CONTAINMFNT INTEGPITY shall exist when:}

a. All penetrations required to be closed during accident conditions are either:

1. Capable of heing closed hy an OPERABLE containment automatic isolation valve system, or

2. Closed by manual valves, blind flanges, or deactivated automatic valves secured in their closed positions, except as provided in Table (3.6-1) of Specification $(3.6 .4 .1)$.

b. All equipment hatches are closed and sealed,

c. Each air lock is OPERABLE pursuant to Specification (3.6.1.3),

d. The containment leakage rates are within the limits of Specification $(3.6 .1 .2)$, and

e. The sealing mechanism associated with each penetration (e.g., welds, bellows or 0 -rings) is OPERABLE.

\section{CHANNEL CALIBRATION}

1.9 A CHANNEL CALIBRATION shall he the adjustment, as necessary, of the channel output such that it responds with the necessary range and accuracy to known values of the parameter which the channel monitors. The CHANNEL CALIBRATION shall encompass the entire channel including the sensor and alarm and/or trip functions, and shall include the CHANINEL FINNCTIONAL TEST. The CHANNEL CALIBRATION may be performed by any series of sequential, overlapping or total channel steps such that the entire channel is calibrated.

\section{CHANNEL CHECK}

1.10 A CHANNEL CHECK shall be the qualitative assessment of channel behavior during operation by observation. This determination shall include, where possible, comparison of the channel indication and/or status with other indications and/or status derived from independent instrument channels measuring the same parameter. 
CHANNEL FUNCTIONAL TFST

1.11 A CHANNEL FUNCTIONAL TEST shall be:

a. Analoc channels - the injection of a simulated sianal into channel as close to the sensor as practicable to verify OPERABILITY including alarm and/or trip functions.

b. Bistable channels - the injection of a simulated signal into the sensor to verify MPERABILITY includina alarm and/or trip functions.

c. Digital computer channels - the exercising of the digital computer hardware using diaqnostic programs and the injection of simulated process data into the channel to verify OPERABILITY.

\section{CORE ALTERATION}

1.12 CORE ALTERATION shall he the movement or manipulation of any component within the reactor pressure vessel with the vessel head removed and fuel in the vessel. Suspension of CORE ALTEPATION shall not preclude completion of movement of a component to a safe conservative position.

\section{SHUTDOWN MARSIN}

1.13 SHITDOWM MARRIN shall be the instantaneous amount of reactivity hy which the reactor is subcritical or would he subcritical from its present condition assumina:

a. No change in part length control element assemply position, and

b. All full length control element assemblies (shutdown and reaulating) are fully inserted except for the single assemhly of hiahest reactivity worth which is assumed to be fully withdrawn.

\section{IDENTIFIED LEAKAGE}

1.14 IDENTIFIED LEAKAGE shall be:

a. Leakage (except CONTROLLED LEAKACE) into closed systems, such as pump seal or valve packing leaks that are captured, and conducted to a sump or collectina tank, or

h. Leakage into the containment atmosphere from sources that are hoth specifically located and known either not to interfere with the operation of leakage detection systems or not to he PRFSSUPF BOUNCARY LEAKACE, or

c. Reactor coolant system leakage through a steam generator to the secondary system. 


\section{UNIDENTIFIED LEAKAGE}

1.15 UNIDENTIFIED LEAKAGE shall be al1 leakage which is not IDENTIFIED LEAKAGE or CONTROLLED LEAKAGE.

\section{PRESSURE BOUNDARY LEAKAGE}

1.16 PRESSURE BOUNDAPY LEAKAGE shall he leakage (except steam generator tuhe leakage) through a non-isolable fault in a Reactor Coolant System component body, pipe wall or vessel wall.

\section{CONTROLLED LEAKAGE}

1.17 CONTROLLEN LEAKAGE shall be the seal water flow supplied to (or from) the reactor coolant pump seals.

AZIMUTHAL POWER TILT - T

1.18 AZIMUTHAL POWER TILT shall be the power asymmetry between azimuthaliy symmetric fuel assemhlies.

DOSE EOUIVALENT I-131

1.19 DOSE EQIIIVALENT I-131 shall be that concentration of 1-131 (microcuries/ gram) which alone would produce the same thyroid dose as the quantity and isotopic mixture of I-131, I-132, I-133, I-134 and I-135 actually present. The thyroid dose conversion factors used for this calculation shall be those listed in Table III of TID-14844, "Calculation of Distance Factors for Power and Test Reactor Sites."

\section{STAGGERED TEST BASIS}

1.20 A STAGGERED TEST RASIS shall consist of:

a. A test schedule for $n$ systems, subsystems, trains or other designated components obtained by dividing the specified test interval into $n$ equal subintervals, and

b. The testing of one system, subsystem, train or other designated component at the beginning of each subinterval. 
FREQUENCY NOTATION

1.21 The FRENUENCY NOTATION specified for the performance of Surveillance Requirements shall correspond to the intervals defined in Table 1.2.

REACTOR TRIP SYSTEM RESPONSE TIME

1.22 The PEACTOR TRIP SYSTEM RESPONSE TIME shall he the time interval from when the monitored parameter exceeds its trip setpoint at the channel sensor until electrical power is interrupted to the CEA drive mechanism.

\section{ENGINEERED SAFETY FEATURE RESPONSE TIME.}

1.23 The ENGINEERED SAFETY FEATURE RESPONSE TIME shall be that time interval from when the monitored parameter exceeds its ESF actuation setpoint at the channel sensor until the ESF equipment is capable of performing its safety function (i.e., the valves travel to their required positions, pump discharge pressures reach their required values, etc.). Times shall include diesel generator starting and sequence loading delays where applicable.

\section{AXIAL SHAPE INDEX}

1.24 The AXIAL SHAPE INDEX shall be the power generated in the lower half of the core less the power generated in the upper half of the core divided by the sum of these powers.

\section{PHYSICS TESTS}

1.25 PHYSICS TESTS shall be those tests performed to measure the fundamental nuclear characteristics of the reactor core and related instrumentation and 1) described in Chapter (14.0) of the FSAR, 2) authorized under the provisions of 10 C.FR 50.59, or 3) otherwise approved by the Commission.

\section{$\bar{E}$ - AVERAGE DISINTEGRATION ENERGY}

$1.26 \bar{E}$ shall he the average (weighted in proportion to the concentration of each radionuclide in the reactor coolant at the time of sampling) of the sum of the average heta and oamma energies per disintegration (in MEV) for isotopes, other than iodines, with half lives greater than 15 minutes, making up at least $95 \%$ of the total non-iodine activity in the coolant. 
SHIELD BUILNING INTEGRITY

\subsection{SHIELD BUILDING INTEGRITY shall exist when:}

a. Each door in each access openina is closed except when the access opening is being used for normal transit entry and exit, then at least one door shall be closed,

b. The shield building filtration system is OPERARLF, and

c. The sealing mechanism associated with each penetration (e.g., welds, bel lows or 0-rings) is OPERARLE.

\section{SOFTWARE}

1.28 The digital computer SOFTHARE for the reactor protection system shall be the program codes including their associated data, documentation and procedures. 
TABLE 1.1

OPERATIONAL MODES

\begin{tabular}{lccc} 
OPERATIONAL MODE & $\begin{array}{c}\text { REACTIVITY } \\
\text { CONDITION, K }\end{array}$ & $\begin{array}{c}\% \text { OF RATED } \\
\text { THERMAL POWER* }\end{array}$ & $\begin{array}{c}\text { AVERAGE COOLANT } \\
\text { TEMPERATURE }\end{array}$ \\
\cline { 2 - 3 } 1. POWER OPERATION & $\geq 0.99$ & $>5 \%$ & $\geq 300^{\circ} \mathrm{F}$ \\
2. STARTUP & $\geq 0.99$ & $\leq 5 \%$ & $\geq 300^{\circ} \mathrm{F}$ \\
3. HOT STANDBY & $<0.99$ & 0 & $\geq 300^{\circ} \mathrm{F}$ \\
4. HOT SHUTDOWN & $<0.99$ & 0 & $300^{\circ} \mathrm{F}>\mathrm{T}_{\text {avg }}>200^{\circ} \mathrm{F}$ \\
5. COLD SHUTDOWN & $<0.99$ & 0 & $\leq 200^{\circ} \mathrm{F}$. \\
6. REFUELING** & $\leq 0.95$ & 0 & $\leq 140^{\circ} \mathrm{F}$
\end{tabular}

\footnotetext{
${ }_{* *}^{\star}$ Excluding decay heat.

Reactor vessel head unbolted or removed and fuel in the vessel.
} 


\section{TABLE 1.2}

\section{FREQUENCY NOTATION}

NOTATION

$S$

D

W

M

Q

- $\quad S A$

$\mathbf{R}$

$S / U$

N.A.

\section{FREQUENCY}

At least once per 12 hours.

At least once per 24 hours.

At least once per 7 days.

At least once per 31 days.

At least once per 92 days.

At least once per 184 days.

At least once per 18 months.

Prior to each reactor startup.

Not applicable. 
SECTION 2.0

SAFETY LIMITS

AND

LIMITING SAFETY SYSTEM SETTINGS 


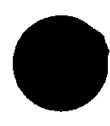

-

• 


\subsection{SAFETY LIMITS AND LIMITING SAFETY SYSTEM SETTINGS}

\section{1 SAFETY LIMITS}

REACTOR CORE

$\underline{\text { DNBR }}$

2.1.1.1 The DNBR of the reactor core shall be maintained greater than or equal to 1.30 .

APPLICABILITY: MODES 1 and 2.

ACTION:

Whenever the DNBR of the reactor has decreased to less than 1.30 , be in HOT STANDBY within 1 hour.

\section{PEAK LINEAR HEAT RATE}

2.1.1.2 The peak 1 inear heat rate (adjusted for fuel rod dynamics) of the fuel shall be maintained less than or equal to $21.0 \mathrm{kw} / \mathrm{ft}$.

APPLICABILITY: MODES 1 and 2.

ACTION:

Whenever the peak 1 inear heat rate (adjusted for fuel rod dynamics) of the fuel has exceeded $21.0 \mathrm{kw} / \mathrm{ft}$, be in HOT STANDBY within 1 hour.

\section{REACTOR COOLANT SYSTEM PRESSURE}

2.1.2 The Reactor Coolant System pressure shall not exceed 2750 psia.

APPLICABILITY: MODES $1,2,3,4$ and 5.

ACTION:

MODES 1 and 2

Whenever the Reactor Coolant System pressure has exceeded 2750 psia, be in HOT STANDBY with the Reactor Coolant System pressure within its limit within 1 hour.

MODES 3,4 and 5

Whenever the Reactor Coolant System pressure has exceeded 2750 psia, reduce the Reactor Coolant System pressure to within its limit within 5 minutes. 


\subsection{LIMITING SAFETY SYSTEM SETTINGS}

\section{REACTOR TRIP SETPOINTS}

2.2.1 The reactor protective instrumentation setpoints shall be set consistent with the Trip Setpoint values shown in Table 2.2-1.

APPLICABILITY: As shown for each channel in Table 3.3-1.

ACTION:

With a reactor protective instrumentation setpoint less conservative than the value shown in the Al lowable Values column of Table 2.2-1, declare the channel inoperable and apply the applicable ACTION statement requirement of Specification 3.3.1 until the channel is restored to OPERABLE status with its trip setpoint adjusted consistent with the Trip Setpoint value. 
TABLE 2.2-1

\section{REACTOR PROTECTIVE INSTRUMENTATION TRIP SETPOINT LIMITS}

\section{FUNCTIONAL UNIT}

1. Manual Reactor Trip

2. Linear Power Level - High

a. Four Reactor Coolant Pumps Operating

b. Three Reactor Coolant Pumps Operating

c. Two Reactor Coolant Pumps Operating - Same Loop

$\stackrel{n}{\omega}$

d. Two Reactor Coolant Pumps Operating - Opposite Loops

\section{TRIP SETPOINT}

Not Applicable

$\leq$ (123)\% of RATED THERMAL POWER

$\star$

*

*

3. Logarithmic Power Level - High (1)

4. Pressurizer Pressure - High

5. Pressurizer Pressure - Low

6. Containment Pressure - High

7. Steam Generator Pressure - Low

究

er

ज্

$$
\begin{aligned}
& \leq(2345) \text { psia } \\
& \geq(1740) \text { psia }(2) \\
& \leq(18.4) \text { psia } \\
& \geq(728) \text { psia }(3) \\
& \geq(46.5) \%(4)
\end{aligned}
$$

*These values left blank pending NRC approval of operation with less than four reactor coolant pumps operating.

\section{ALLOWABLE VALUES}

Not Applicable

$\leq(123.712) \%$ of RATED THERMAL POWER

$\star$

$\star$

*

$\leq(0.819) \%$ of RATED THERMAL POWER

$\leq(2353.887)$ psia

$\geq(1686.75)$ psia (2)

$\leq(19.024)$ psia

$\geq(706.6)$ psia (3)

$\geq(45.61) \%(4)$ 


\section{FUNCTIONAL UNIT}

9. Local Power Density - High

10. DNBR - Low

11. Steam Generator Level - High

\section{TRIP SETPOINT}

$\leq(20.3) \mathrm{kw} / \mathrm{ft}(5)$

$\geq(1.3)(5)$

$\leq(93.6) \%(4)$

\section{ALLOWABLE VALUES}

$\leq(20.3) \mathrm{kw} / \mathrm{ft}(5)$

$\geq(1.3)(5)$

$\leq(94.489) \%(4)$

\section{TABLE NOTATION}

(1) Trip may be manually bypassed above $\left(10^{-4}\right) \%$ of RATED THERMAL POWER; bypass shall be automatically removed when THERMAL POWER is less than or equal to $\left(10^{-4}\right) \%$ of RATED THERMAL POWER.

(2) Value may be decreased manually, to a minimum of (100) psia, as pressurizer pressure is reduced, provided the margin between the pressurizer pressure and this value is maintained at less than or equal to (200) psi; the setpoint shall be increased automatically as pressurizer pressure is increased until the trip setpoint is reached. Trip may be manually bypassed below (400) psia; bypass shall be automatically removed whenever pressurizer pressure is greater than or equal to $(500)$ psia.

(3) Value may be decreased manually as steam generator pressure is reduced, provided the margin between the steam generator pressure and this value is maintained at less than or equal to (200) psi; the setpoint shall be increased automatically as steam generator pressure is increased until the trip setpoint is reached.

(4) \% of the distance between steam generator upper and low level instrument nozzles.

(5) As stored within the Core Protection Calculator (CPC). Calculation of the trip setpoint includes measurement, calculational and processor uncertainties, and dynamic allowances. Trip may be manually bypassed below $\left(10^{-4}\right) \%$ of RATED THERMAL POWER; bypass shall be automatically removed when THERMAL POWER is greater than or equal to $\left(10^{-4}\right) \%$ of RATED THERMAL POWER. 


\section{BASES}

FOR

SECTION 2.0

SAFETY LIMITS

AND

LIMITING SAFETY SYSTEM SETTINGS 

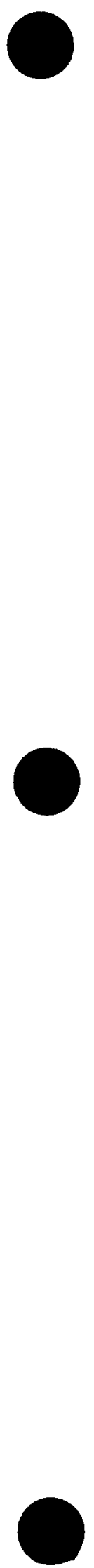


\section{NOTE}

The summary statements contained in this section provide the bases for the specifications of Section 2.0 and are not considered a part of these technical specifications as provided in 10 CFR 50.36. 


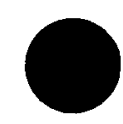

-

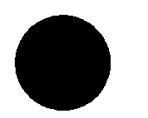


2.1 and 2.2 SAFETY LIMITS AND LIMITING SAFETY SYSTEM SETTINGS

RASES

\subsubsection{REACTOR CORE}

The restrictions of these safety limits prevent overheating of the fuel cladding and possible cladding perforation which would result in the release of fission products to the reactor coolant. Overheating of the fuel cladding is prevented by (1) restricting fuel operation to within the nucleate boiling regime where the heat transfer coefficient is large and the cladding surface temperature is slightly above the coolant saturation temperature, and (2) maintaining the dynamically adjusted peak linear heat rate of the fuel at or less than $21 \mathrm{kw} / \mathrm{ft}$ which will not cause fuel centerline melting in anv fuel rod.

First, hy operating within the nucleate boilina regime of heat transfer, the heat transfer coefficient is large enough so that the maximum clad surface temperature is only slightly greater than the coolant saturation temperature. The upper boundary of the nucleate boiling regime is termed "departure from nucleate boiling" (DNB). At this point, there is a sharp reduction of the heat transfer coefficient, which would result in higher cladding temperatures and the possibility of cladding failure.

Correlations predict nNR and the location of DNR for axially uniform and non-uniform heat flux distributions. The local DNB ratio (DNBR), defined as the ratio of the predicted DNB heat flux at a particular core location to the actual heat flux at that location, is indicative of the margin to nNB. The minimum value of DNBR during normal operational occurrences is limited to 1.3 for the $W-3$ correlation and is established as a Safety Limit.

Second, operation with a peak linear heat rate below that which would cause fuel centerline melting maintains fuel rod and cladding integrity. Above this peak linear heat rate level (i.e., with some melting in the center), fuel rod integrity would be maintained only if the design and operating conditions are appropriate throughout the life of the fuel rods. Volume changes which accompany the solid to liquid phase change are significant and require accomodation. Another consideration involves the redistribution of the fuel which depends on the extent of the melting and the physical state of the fuel rod at the time of melting. Recause of the ahove factors, the steady state value of the peak linear heat rate which would not cause fuel centerline melting is established as a Safety Limit. To account for fuel rod dynamics (lags), the directly indicated linear heat rate is dynamically adjusted.

Limiting safety system settinas for the Low DNRR, High Local Power Density, High Logarithmic Power Level, Low Pressurizer Pressure and High Linear Power Level trips, and limiting conditions for operation on DNBR and $\mathrm{kw} / \mathrm{ft}$ marain are specified such that there is a high degree of confidence that the specified acceptable fuel design limits are not exceeded during normal operation and design hasis anticipated operational occurrences. 


\subsubsection{REACTOR COOLANT SYSTEM PRESSURE}

The restriction of this Safety Limit protects the integrity of the Reactor Coolant System from overpressurization and thereby prevents the release of radionuclides contained in the reactor coolant from reaching the containment atmosphere.

The Reactor Coolant System components are designed to Section III, Edition, of the ASME Code for Nuclear Power Plant Components which permits a maximum transient pressure of $110 \%$ (2750 psia) of design pressure. The Safety Limit of 2750 psia is therefore consistent with the design criteria and associated code reauirements.

The entire Reactor Coolant System is hydrotested at 3125 psia to demonstrate integrity prior to initial operation.

\subsubsection{REACTOR TRIP SETPOINTS}

The Reactor Trip Setpoints specified in Table 2.2-1 are the values at which the Reactor Trips are set for each functional unit. The Trip Setpoints have been selected to ensure that the reactor core and reactor coolant svstem are prevented from exceeding their Safety Limits during normal operation and design basis anticipated operational occurrences and to assist the Engineered Safety Features Actuation System in mitigating the consequences of accidents. Operation with a trip set less conservative than its Trip Setpoint but within its specified Allowable Value is acceptable on the basis that the difference between each Trip Setpoint and the Allowable Value is equal to or less than the drift allowance assumed for each trip in the safety analyses.

The DNBR - Low and Local Power Density - High are digitally generated trip setpoints based on Limiting Safety System Settings of 1.30 and 20.3 $\mathrm{kw} / \mathrm{ft}$, respectively. Since these trips are diaitally generated by the Core Protection Calculators, the trip values are not subject to drifts common to trips generated by analog type equipment. The Allowable Values for these trips are therefore the same as the Trip Setpoints.

To maintain the margins of safety assumed in the safety analyses, the calculations of the trip variables for the DNBR - Low and Local Power Density High trips include the measurement, calculational and processor uncertainties and dynamic allowances as defined in (reference applicable system descriptions and safety analyses).

\section{Manual Reactor Trip}

The Manual Reactor Trip is a redundant channel to the automatic protective instrumentation channels and provides manual reactor trip capability. 
SAFETY LIMITS AND LIMITING SAFETY SYSTEM SETTINGS

BASES

Linear Power Level-High

The Linear Power Leve1-High trip provides reactor core protection against rapid reactivity excursions which might occur as the result of an ejected CEA. This trip initiates a reactor trip at a linear power level of less than or equal to $(123.712) \%$ of RATED THERMAL POWER.

Logarithmic Power Level-High

The Logarithmic Power Level - High trip is provided to protect the integrity of fuel cladding and the Reactor Coolant System pressure boundary in the event of an unplanned criticality from a shutdown condition. A reactor trip is initiated by the Logarithmic Power Level - High trip at a THERMAL POWER level of less than or equal to $(0.819) \%$ of RATED THERMAL POWER unless this trip is manually bypassed by the operator. The operator may manually bypass this trip when the THERMAL POWER level is above $\left(10^{-4}\right) \%$ of RATED THERMAL POWER; this ${ }_{4}$ bypass is automatically removed when the THERMAL POWER level decreases to $\left(10^{-4}\right) \%$ of RATED THERMAL POWER.

\section{Pressurizer Pressure-High}

The Pressurizer Pressure-High trip, in conjunction with the pressurizer safety valves and main steam safety valves, provides reactor coolant system protection against overpressurization in the event of loss of load without reactor trip. This trip's setpoint is at less than or equal to (2353.887) psia which is below the nominal lift setting (2500 psia) of the pressurizer safety valves and its operation avoids the undesirable operation of the pressurizer safety valves.

\section{Pressurizer Pressure-Low}

The Pressurizer Pressure-Low trip is provided to trip the reactor and to assist the Engineered Safety Features System in the event of a Loss of Coolant Accident. During normal operation, this trip's setpoint is set at greater than or equal to (1686.75) psia. This trip's setpoint may be manually decreased, to a minimum value of (100) psia, as pressurizer pressure is reduced during plant shutdowns, provided the margin between the pressurizer pressure and this trip's setpoint is maintained at less than or equal to (200) psi; this setpoint increases automatically as pressurizer pressure increases until the trip setpoint is reached. 
Containment Pressure-High

The Containment Pressure-High trip provides assurance that a reactor trip is initiated concurrently with a safety injection. The setpoint for this trip is identical to the safety injection setpoint.

\section{Steam Generator Pressure-Low}

The Steam Generator Pressure-Low trip provides protection against an excessive rate of heat extraction from the steam generators and subsequent cooldown of the reactor coolant. The setpoint is sufficiently below the full load operating point of approximately (900) psia so as not to interfere with normal operation, but still high enough to provide the required protection in the event of excessively high steam flow. This trip's setpoint may be manually decreased as steam generator pressure is reduced during plant shutdowns, provided the margin between the steam generator pressure and this trip's setpoint is maintained at less than or equal to (200) psi; this setpoint increases automatically as steam generator pressure increases until the trip setpoint is reached.

Steam Generator Level-Low

The Steam Generator Level-Low trip provides protection against a loss of feedwater flow incident and assures that the design pressure of the Reactor Coolant System will not be exceeded due to loss of the steam generator heat sink. This specified setpoint provides allowance that there will be sufficient water inventory in the steam generator at the time of the trip to provide a margin of at least 10 minutes before emergency feedwater is required.

\section{Local Power Density-High}

The Local Power Density-High trip is provided to prevent the 1 inear heat rate $(\mathrm{kw} / \mathrm{ft})$ in the limiting fuel rod in the core from exceeding the fuel design limit in the event of any anticipated operational occurrence. The local power density is calculated in the reactor protective system utilizing the following information:

a. Nuclear flux power and axial power distribution from the excore flux monitoring system;

b. Radial peaking factors from the position measurement for the CEAs;

c. Delta $T$ power from reactor coolant temperatures and coolant flow measurements. 
SAFETY LIMITS AND LIMITING SAFETY SYSTEM SETTINGS

BASES

Local Power Density-High (Continued)

The local power density (LPD), the trip variable, calculated by the CPC incorporates uncertainties and dynamic compensation routines. These uncertainties and dynamic compensation routines ensure that a reactor trip occurs when the actual core peak LPD is sufficiently less than the fuel design limit such that the increase in actual core peak LPD after the trip will not result in a violation of the peak LPD Safety Limit. CPC uncertainties related to peak LPD are the same types used for DNBR calculation. Dynamic compensation for peak LPD is provided for the effects of core fuel centerline temperature delays (relative to changes in power density), sensor time delays, and protection system equipment time delays.

DNBR-LOW

The DNBR - Low trip is provided to prevent the DNBR in the limiting coolant channel in the core from exceeding the fuel design limit in the event of anticipated operational occurrences. The DNBR - Low trip incorporates a low pressurizer pressure floor of $1750 \mathrm{psia}$. At this pressure a DNBR - Low trip will automatically occur. The DNBR is calculated in the CPC utilizing the following information:

a. Nuclear flux power and axial power distribution from the excore neutron flux monitoring system;

b. Reactor Coolant System pressure from pressurizer pressure measurement;

c. Differential temperature (Delta T) power from reactor coolant temperature and coolant flow measurements;

d. Radial peaking factors from the position measurement for the CEAs;

e. Reactor coolant mass flow rate from reactor coolant pump speed;

f. Core inlet temperature from reactor coolant cold leg temperature measurements.

The DNBR, the trip variable, calculated by the CPC incorporates various uncertainties and dynamic compensation routines to assure a trip is initiated prior to violation of fuel design limits. These uncertainties and dynamic compensation routines ensure that a reactor trip occurs when the actual core DNBR is sufficiently greater than 1.3 such that the decrease in actual core 
DNBR-Low (Continued)

DNBR after the trip will not result in a violation of the DNBR Safety Limit. CPC uncertainties related to DNBR cover CPC input measurement uncertainties, a)gorithm modelling uncertainties, and computer equipment processing uncertainties. Dynamic compensation is provided in the CPC calculations for the effects of coolant transport delays, core heat flux delays (relative to changes in core power), sensor time delays, and protection system equipment time delays.

The DNBR algorithm used in the CPC is valid only within the limits indicated below and operation outside of these limits will result in a CPC initiated trip.
a. RCS Cold Leg Temperature-Low
b. RCS Cold Leg Temperature-High
c. Axial Shape Index-Positive
d. Axial Shape Index-Negative
e. Pressurizer Pressure-Low
f. Pressurizer Pressure-High
g. Integrated Radial Peaking Factor-Low
h. Integrated Radial Peaking Factor-High
i. Quality Margin-Low

$\geq(465)^{\circ} \mathrm{F}$
$<(605)^{\circ} \mathrm{F}$

Not more positive than $+(0.6)$

Not more negative than $-(0.6)$

$\geq(1750)$ psia

$\leq(2400)$ psia

$\geq(1.28)$

$\leq(4.28)$

$\Sigma(0)$

\section{Steam Generator Level-High}

The Steam Generator Leve1-High trip is provided to protect the turbine from excessive moisture carry over. Since the turbine is automatically tripped when the reactor is tripped, this trip provides a reliable means for providing protection to the turbine from excessive moisture carry over. This trip's setpoint does not correspond to a Safety Limit and no credit was taken in the accident analyses for operation of this trip. Its functional capability at the specified trip setting is required to enhance the overall reliability of the Reactor Protection System. 
SECTIONS 3.0 AND 4.0

LIMITING CONDITIONS FOR OPERATION

AND

SURVEILLANCE REQUIREMENTS 

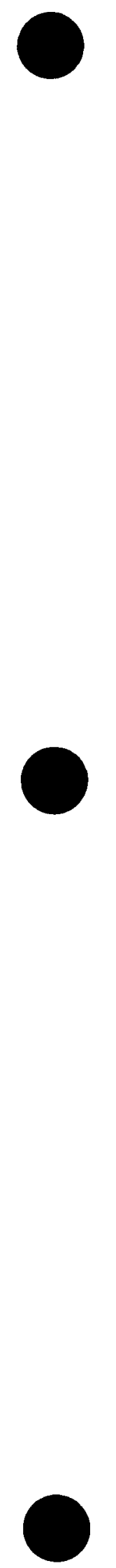
$3 / 4$ LIMITING CONDITIONS FOR OPERATION AND SURVEILLANCE REQUIREMENTS

3/4.0 APPLICABILITY

LIMITING CONDITION FOR OPERATION

3.0.1 Limiting Conditions for Operation and ACTION requirements shall be applicable during the OPERATIONAL MODES or other conditions specified for each specification.

3.0.2 Adherence to the requirements of the Limiting Condition for Operation and/or associated ACTION within the specified time interval shall constitute compliance with the specification. In the event the Limiting Condition for Operation is restored prior to expiration of the specified time interval, completion of the ACTION statement is not required.

3.0.3 In the event a Limiting Condition for Operation and/or associated ACTION requirements cannot be satisfied because of circumstances in excess of those addressed in the specification, the unit shall be placed in at least HOT STANDBY within 1 hour, in at least HOT SHUTDOWN within the next 6 hours, and in at least COLD SHUTDOWN within the following 24 hnurs unless corrective measures are completed that permit operation under the permissible ACTION statements for the specified time interval as measured from initial discovery or until the reactor is placed in a MODE in which the specification is not applicable. Exceptions to these requirements shall be stated in the individual specifications.

3.0.4 Entry into an OPERATIONAL MODE or other specified applicability condition shall not be made unless the conditions of the Limiting Condition for Operation are met without reliance on provisions contained in the ACTION statements unless otherwise excepted. This provision shall not prevent passage through OPERATIONAL MODES as required to comply with ACTION statements.

\section{SURVEILLANCE REQUIREMENTS}

4.0.1 Surveillance Requirements shall be applicable during the OPERATIONAL MODES or other conditions specified for individual Limiting Conditions for Operation unless otherwise stated in an individual Surveillance Requirement.

4.0.2 Each Surveillance Requirement shall be performed within the specified time interval with:

a. A maximum allowable extension not to exceed $25 \%$ of the surveillance interval, and

b. A total maximum combined interval time for any 3 consecutive surveillance intervals not to exceed 3.25 times the specified surveillance interval. 
4.0.3 Performance of a Surveillance Requirement within the specified time interval shall constitute compliance with OPERABILITY requirements for a Limiting Condition for Operation and associated ACTION statements unless otherwise required by the specification. Surveillance Requirements do not have to be performed on inoperable equipment.

4.0.4 Entry into an OPERATIONAL MODE or other specified applicability condition shall not be made unless the Surveillance Requirement(s) associated with the Limiting Condition for Operation have been performed within the stated surveillance interval or as otherwise specified.

4.0.5 Surveillance Requirements for inservice inspection and testing of ASME Code Class 1, 2 and 3 components shall be applicable as follows:

a. During the time period:

1. From issuance of the Facility Operating License to the start of facility commercial operation, inservice testing of ASME Code Class 1,2 and 3 pumps and valves shall be performed in accordance with Section XI of the ASME Boiler and Pressure Vessel Code (*) Edition, and Addenda through $\left(^{*}\right)$ except where specific written relief has been granted by the Commission.

2. Following start of facility commerical operation, inservice inspection of ASME Code Class 1,2 and 3 components and inservice testing ASME Code Class 1, 2 and 3 pumps and valves shall be performed in accordance with Section XI of the ASME Boiler and Pressure Vessel Code and applicable Addenda as required by 10 CFR 50 , Section $50.55 \mathrm{a}(\mathrm{g})$, except where specific written relief has been granted by the Commission pursuant to 10 CFR 50, Section 50.55a(g)(6)(i).

b. Surveillance intervals specified in Section XI of the ASME Boiler and Pressure Vessel Code and applicable Addenda for the inservice inspection and testing activities required by the ASME Boiler and Pressure Vessel Code and applicable Addenda shall be applicable as follows in these Technical Specifications:

ॠSpecific Code Edition and Addenda are to be specified consistent with 10 CFR 50.55a(b). 
ASME Boiler and Pressure Vessel Code and applicable Addenda terminology for inservice inspection and testing activities

Weekly

Monthly

Quarterly or every 3 months

Semiannually or every 6 months Yearly or annually \begin{tabular}{l} 
Required frequencies \\
for performing inservice \\
inspection and testing \\
activicies \\
\hline
\end{tabular}

At least once per 7 days

At least once per 31 days

At least once per 92 days

At least once per 184 days

At least once per 366 days

c. The provisions of Specification 4.0.2 are applicable to the above required frequencies for performing inservice inspection and testing activities.

d. Performance of the above inservice inspection and testing activities shall be in addition to other specified Surveillance Requirements.

e. Nothing in the ASME Boiler and Pressure Vessel Code shall be construed to supersede the requirements of any Technical Specification. 

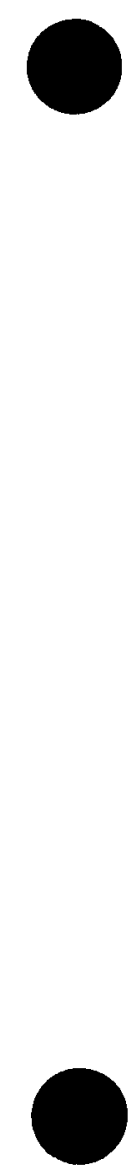

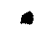


3/4.1 REACTIVITY CONTROL SYSTEMS

3/4.1.1 BORATION CONTROL

SHUTDOWN MARGIN - $T_{\text {avg }}$ GREATER THAN $200^{\circ} \mathrm{F}$

LIMITING CONDITION FOR OPERATION

3.1.1.1 The SHUTDOWN MARGIN shall be greater than or equal to $(5.0) \% \mathrm{de} 1 \mathrm{ta} \mathrm{k} / \mathrm{k}$. APPLICABILITY: MODES $1,2^{*}, 3$ and 4.

\section{ACTION:}

With the SHUTDOWN MARGIN less than (5.0)\% delta k/k, immediately initiate and continue boration at greater than or equal to (40) $\mathrm{gpm}$ of (1731) $\mathrm{ppm}$ boric acid solution or equivalent until the required SHUTDOWN MARGIN is restored.

\section{SURVEILLANCE REQUIREMENTS}

4.1.1.1.1 The SHUTDOWN MARGIN shall be determined to be greater than or equal to $(5.0) \%$ delta $k / k$ :

a. Within one hour after detection of an inoperable CEA(s) and at least once per 12 hours thereafter while the CEA(s) is inoperable. If the inoperable CEA is immovable or untrippable, the above required SHUTDOWN MARGIN shall be verified acceptable with an increased allowance for the withdrawn worth of the immovable or untrippable $\mathrm{CEA}(\mathrm{s})$.

b. When in MODES 1 or $2^{\#}$, at least once per 12 hours by verifying that CEA group withdrawal is within the Transient Insertion Limits of Specification 3.1.3.6.

c. When in MODE $2^{\# \#}$, within 4 hours prior to achieving reactor criticality by verifying that the predicted critical CEA position is within the limits of Specification (3.1.3.6).

\footnotetext{
\# See Special Test Exception 3.10.1.

\# With $K_{\text {eff }}$ greater than or equal to 1.0 .

With $K_{\text {eff }}$ less than 1.0 .
} 
d. Prior to initial operation above 5\% RATED THERMAL POWER after each fuel loading, by consideration of the factors of e helow, with the CEA groups at the Transient Insertion Limits of Specification 3.1.3.6.

e. When in MODES 3 or 4, at least once per 24 hours by consideration of at least the followino factors:

1. Reactor coolant system boron concentration,

2. TEA position,

3. Peactor coolant system average temperature,

4. Fuel burnup based on gross thermal eneray generation,

5. Xenon concentration, and

6. Samarium concentration.

4.1.1.1.2 The overall core reactivity halance shall be compared to predicted values to demonstrate agreement within $\pm 1.0 \%$ delta $\mathrm{k} / \mathrm{k}$ at least once per 31 Effective Full Power nays (EFPN). This comparison shall consider at least those factors stated in Specification 4.1.1.1.1.e, above. The predicted reactivity values shall he adiusted (normalized) to correspond to the actual core conditions prior to exceeding a fuel burnup of 60 Effective Full Power nays after each fuel loadino. 
REACTIVITY CONTROL SYSTEMS

SHUTDOWN MARGIN - $T_{\text {avg }}$ LESS THAN OR EQUAL TO $200^{\circ} \mathrm{F}$

LIMITING CONDITION FOR OPERATION

3.1.1.2 The SHUTDOWN MARGIN shall be greater than or equal to $(1.0) \%$ delta $k / k$. APPLICABILITY: MODE 5.

ACTION:

With the SHUTDOWN MARGIN less than $(1.0) \%$ delta $\mathrm{k} / \mathrm{k}$, immediately initiate and continue boration at greater than or equal to (40) $\mathrm{gpm}$ of (1731) ppm boric acid solution or equivalent until the required SHUTDOWN MARGIN is restored.

4.1.1.2 The SHUTDOWN MARGIN shall be determined to be greater than or equal to $(1.0) \%$ delta $k / k$ :

a. Within one hour after detection of an inoperable CEA(s) and at least once per 12 hours thereafter while the CEA $(s)$ is inoperable. If the inoperable CEA is immovable or untrippable, the above required SHUTDOWN MARGIN shall be increased by an amount at least equal to the withdrawn worth of the immovable or untrippable CEA(s).

b. At least once per 24 hours by consideration of the following factors:

1. Reactor coolant system boron concentration,

2. CEA position,

3. Reactor coolant system average temperature,

4. Fuel burnup based on gross thermal energy generation,

5. Xenon concentration, and

6. Samarium concentration. 
3.1.1.3 The moderator temperature coefficient (MTC) shall be:

a. Less positive than $(0.5) \times 10^{-4} \mathrm{delta} \mathrm{k} / \mathrm{k} /{ }^{\circ} \mathrm{F}$, and

b. Less negative than $(-3.5) \times 10^{-4}$ delta $k / k /{ }^{\circ} \mathrm{F}$ at RATED THERMAL POWER. APPLICABILITY: MODES 1 and $2 * \#$

\section{ACTION:}

With the moderator temperature coefficient outside any one of the above limits, be in at least HOT STANDBY within 6 hours.

\section{SURVEILLANCE REQUIREMENTS}

4.1.1.3.1 The MTC shall be determined to be within its limits by confirmatory measurements. MTC measured values shall be extrapolated and/or compensated to permit direct comparison with the above limits.

4.1.1.3.2 The MTC shall be determined at the following frequencies and THERMAL POWER conditions during each fuel cycle:

a. Prior to initial operation above $5 \%$ of RATED THERMAL POWER, after each fuel loading.

b. At any THERMAL POWER, within 7 EFPD after reaching a RATED THERMAL POWER equilibrium boron concentration of (800) ppm.

c. At any THERMAL POWER, within 7 EFPD after reaching a RATED THERMAL POWER equilibrium boron concentration of (300) ppm.

*With $K_{\text {eff }}$ greater than or equal to 1.0 . \#See Special Test Exception 3.10.2. 
REACTIVITY CONTROL SYSTEMS

MINIMUM TEMPERATIIPE FOR CPITICALITY

LIMITING CONNITION FOR OPERATION

3.1.1.4 The Peactor Coolant System lowest operating loop temperature ( $T$ avq ${ }^{\prime}$ shall be greater than or equal to $(525)^{\circ} \mathrm{F}$ when the reactor is critical. ava

APPLICABILITY: MODES 1 and $2 \#$.

\section{ACTION:}

With a Reactor Coolant System operating loop temperature ( $T_{\text {ayg }}$ ) less than $(525)^{\circ} \mathrm{F}$, restore $\mathrm{T}$ to within its limit within 15 minutes ${ }^{9} \mathrm{P}^{\prime}$ be in HOT STANDBY within the aygxt 15 minutes.

SURVEILLANCE REOUIREMENTS

4.1.1.4 The Reactor Coolant System temperature $\left(T_{a v a}\right)$ shall be determined to be greater than or equal to $(525)^{\circ} \mathrm{F}$ :

a. Within 15 minutes prior to achieving reactor criticality, and

b. At least once per 30 minutes when the reactor is critical and the Reactor Coolant System $\mathrm{T}_{\text {ava }}$ is less than $(535)^{\circ} \mathrm{F}$.

\#With $K_{\text {eff }}$ greater than or equal to $1 . n$. 
REACTIVITY CONTROL SYSTEMS

3/4.1.2 BORATION SYSTEMS

FLOW PATHS - SHUTDOWN

LIMITING CONDITION FOR OPERATION

3.1.2.1 As a minimum, one of the following boron injection flow paths and one associated heat tracing circuit shall be OPERABLE:

a. A flow path from the boric acid makeup tank via either a boric acid makeup pump or a gravity feed connection and charging pump to the Reactor Coolant System if only the boric acid makeup tank in Specification 3.1.2.7a is OPERABLE, or

b. The flow path from the refueling water tank via either a charging pump or a high pressure safety injection pump to the Reactor Coolant System if only the refueling water tank in Specification 3.1.2.7b is OPERABLE.

APPLICABILITY: MODES 5 and 6.

ACTION:

With none of the above flow paths OPERABLE, suspend all operations involving CORE ALTERATIONS or positive reactivity changes.

SURVEILLANCE REQUIREMENTS

4.1.2.1 At least one of the above required flow paths shall be demonstrated OPERABLE:

a. At least once per 7 days by verifying that the temperature of the heat traced portion of the flow path is above the temperature limit line shown on Figure $(3.1-1)$ when a flow path from the boric acid makeup tanks is used.

b. At least once per 31 days be verifying that each valve (manual, power operated or automatic) in the flow path that is not locked, sealed, or otherwise secured in position, is in its correct position. 
FLOW PATHS - OPERATING

3.1.2.2 At least two of the following three boron injection flow paths and one associated heat tracing circuit shall be OPERABLE:

a. Two flow paths from the boric acid makeup tanks via either a boric acid makeup pump or a gravity feed connection, and a charging pump to the Reactor Coolant System, and

b. The flow path from the refueling water tank via a charging pump to the Reactor Coolant System.

APPLICABILITY: MODES $1,2,3$ and 4.

ACTION:

With only one of the above required boron injection flow paths to the Reactor Coolant System OPERABLE, restore at least two boron injection flow paths to the Reactor Coolant System to OPERABLE status within 72 hours or be in at least HOT STANDBY and borated to a SHUTDOWN MARGIN equivalent to at least $1 \%$ del ta $\mathrm{k} / \mathrm{k}$ at $200^{\circ} \mathrm{F}$ within the next 6 hours; restore at least two flow paths to OPERABLE status within the next 7 days or be in COLD SHUTDOWN within the next 30 hours.

SURVEILLANCE REQUIREMENTS

4.1.2.2 At least two of the above required flow paths shall be demonstrated OPERABLE :

a. At least once per 7 days by verifying that the temperature of the heat traced portion of the flow path from the boric acid makeup tanks is above the temperature limit line shown on Figure $(3.1-1)$.

b. At least once per 31 days by verifying that each valve (manual, power operated or automatic) in the fiow path that is not locked, sealed, or otherwise secured in position, is in its correct position.

c. At least once per 18 months during shutdown by verifying that each automatic valve in the flow path actuates to its correct position on a (SIAS) test signal. 
REACTIVITY CONTROL SYSTEMS

CHARGING PUMP - SHUTDOWN

LIMITING CONDITION FOR OPERATION

3.1.2.3 At least one charging pump or one high pressure safety injection pump in the boron injection flow path required OPERABLE pursuant to Specification 3.1.2.1 shall be OPERABLE and capable of being powered from an OPERABLE emergency bus.

APPLICABILITY: MODES 5 and 6.

ACTION:

With no charging pump or high pressure safety injection pump OPERABLE, suspend all operations involving CORE ALTERATIONS or positive reactivity changes.

4.1.2.3 At least the above required pump shall be demonstrated OPERABLE by verifying, that on recirculation flow, the charging pump (if applicable) develops a discharge pressure of greater than or equal to psig or the high pressure safety injection pump (if applicable) develops a discharge pressure of greater than or equal to Specification 4.0.5. psig when tested pursuant to 
REACTIVITY CONTROL SYSTEMS

CHARGING PUMPS - OPERATING

LIMITING CONDITION FOR OPERATION

3.1.2.4 At least two charging pumps shall be OPERABLE.

APPLICABILITY: MODES 1, 2, 3 and 4.

ACTION:

With only one charging pump OPERABLE, restore at least two charging pumps to

OPERABLE status within 72 hours or be in at least HOT STANDBY and borated to a SHUTDOWN MARGIN equivalent to at least $1 \%$ delta $\mathrm{k} / \mathrm{k}$ at $200^{\circ} \mathrm{F}$ within the next 6 hours; restore at least two charging pumps to OPERABLE status within the next 7 days or be in COLD SHUTDOWN within the next 30 hours.

4.1.2.4 At least two charging pumps shall be demonstrated OPERABLE by verifying, that on recirculation flow, each pump develops a discharge pressure of greater than or equal to psig when tested pursuant to Specification 4.0.5. 
3.1.2.5 At least one boric acid makeup pump shall be OPERABLE and capable of being powered from an OPERABLE emergency bus if only the flow path through the boric acid pump in Specification 3.1.2.1 a is OPERABLE.

APPLICABILITY: MODES 5 and 6 .

ACTION:

With no boric acid makeup pump OPERABLE as required to complete the flow path of Specification 3.1.2.1a, suspend all operations involving CORE ALTERATIONS or positive reactivity changes.

4.1.2.5 The above required boric acid makeup pump shall be demonstrated OPERABLE by verifying, that on recirculation flow, the pump develops a discharge pressure of greater than or equal to to Specification 4.0.5. psig when tested pursuant 
REACTIVITY CONTROL SYSTEMS

BORIC ACID MAKEUP PUMPS - OPERATING

LIMITING CONDITION FOR OPERATION

3.1.2.6 At least the boric acid makeup pump(s) in the boron injection flow path $(s)$ required OPERABLE pursuant to Specification 3.1 .2 .22 shall be OPERABLE and capable of being powered from an OPERABLE emergency bus if the flow path through the boric as id pump(s) in Specification 3.1.2.2a is OPERABLE.

APPLICABILITY: MODES $1,2,3$ and 4.

ACTION:

With one boric acid makeup pump required for the boron injection flow path(s) pursuant to Specification 3.1.2.2a inoperable, restore the boric acid makeup pump to OPERABLE status within 72 hours or be in at least HOT STANDBY within the next 6 hours and borated to a SHUTDOWN MARGIN equivalent to at least $1 \%$ delta $\mathrm{k} / \mathrm{k}$ at $200^{\circ} \mathrm{F}$; restore the above required boric acid makeup pump $(\mathrm{s})$ to OPERABLE status with in the next 7 days or be in COLD SHUTDOWN within the next 30 hours.

4.1.2.6 The above required boric acid makeup pump(s) shall be demonstrated OPERABLE by verifying, that on recirculation flow, the pump (s) develop a discharge pressure of greater than or equal to psig when tested pursuant to Specification 4.0 .5 . 
REACTIVITY CONTROL SYSTEMS

BORATED WATER SOURCE - SHUTDOWN

3.1.2.7 As a minimum, one of the following borated water sources shall be OPERABLE:

a. One boric acid makeup tank and at least one associated heat tracing circuit with the tank contents in accordance with Figure (3.1-1).

b. The refueling water tank with:

1. A minimum contained borated water volume of $(35,250)$ gallons,

2. A minimum boron concentration of (1731) $\mathrm{ppm}$, and

3. A minimum solution temperature of $(35)^{\circ} \mathrm{F}$.

APPLICABILITY: MODES 5 and 6.

ACTION:

With no borated water sources OPERABLE, suspend all operations involving CORE ALTERATIONS or positive reactivity changes.

\section{SURVEILLANCE REQUIREMENTS}

4.1.2.7 The above required borated water source shall be demonstrated OPERABLE:

a. At least once per 7 days by:

1. Verifying the boron concentration of the water,

2. Verifying the contained borated water volume of the tank, and

3. Verifying the boric acid makeup tank solution temperature when it is the source of borated water.

b. At least once per 24 hours by verifying the RWT temperature when it is the source of borated water and the (outside) air temperature is less than $(35)^{\circ} \mathrm{F}$. 


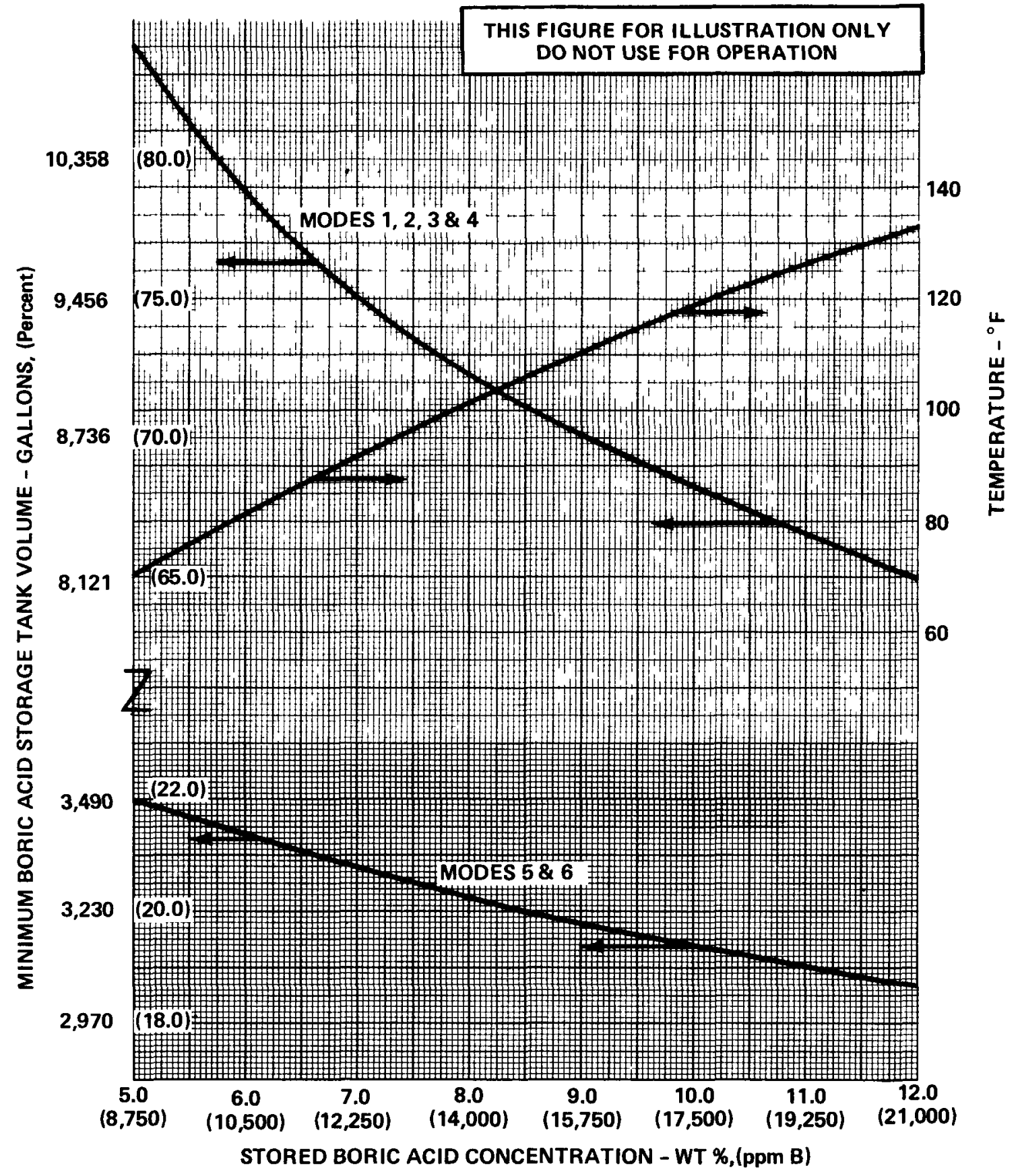

Figure 3.1-1

Minımum Boric Acid Storage Tank Volume and Temperature as a Function of Stored Boric Acid Concentration 
REACTIVITY CONTROL SYSTEMS

BORATED WATER SOURCES - OPERATING

LIMITING CONDITION FOR OPERATION

3.1.2.8 Each of the following borated water sources shall be OPERABLE:

a. At least one boric acid makeup tank and at least one associated heat tracing circuit per tank with the contents of the tank in accordance with Figure $(3.1-1)$, and

b. The refueling water tank with:

1. A contained borated water volume of between $(464,900)$ and $(500,500)$ gallons,

2. Between (1737) and (2250) ppm of boron, and

3. A minimum solution temperature of $(35)^{\circ} \mathrm{F}$.

APPLICABILITY: MODES $1,2,3$ and 4.

ACTION:

a. With the above required boric acid makeup tank inoperable, restore the tank to OPERABLE status within 72 hours or be in at least HOT STANDBY within the next 6 hours and borated to a SHUTDOWN MARGIN equivalent to at least $1 \%$ delta $\mathrm{k} / \mathrm{k}$ at $200^{\circ} \mathrm{F}$; restore the above required boric acid makeup tank to OPERABLE status within the next 7 days or be in COLD SHUTDOWN within the next 30 hours.

b. With the refueling water tank inoperable, restore the tank to OPERABLE status within one hour or be in at least HOT STANDBY within the next 6 hours and in COLD SHUTDOWN within the following 30 hours.

4.1.2.8 Each borated water sources shall be demonstrated OPERABLE:

a. At least once per 7 days by:

1. Verifying the boron concentration in the water,

2. Verifying the contained borated water volume of the water source, and

3. Verifying the boric acid makeup tank solution temperature.

b. At least once per 24 hours by verifying the RWT temperature when the (outside) air temperature is less than $(35)^{\circ} \mathrm{F}$. 
REACTIVITY CONTROL SYSTFMS

3/4.1.3 MOVABLE CONTPOL ASSEMRLIES

CEA POSITION

LIR:ITING CONDITION FOR OPERATION!

3.1.3.1 All full length (shutdown and requlatina) CEAs, and all part length CEAs which are inserted in the core, shall be CPERARLE with each CFA of a given group positioned within 7 inches (indicated position) of all other CEAs in its aroup.

APPLICARILITY: MODES 1 * and $2 *$.

ACTION:

a. With one or more full length CFAs inoperable due to he ina immovahle as a result of excessive friction or mechanical interference or known to be untrippable, determine that the SHITIOWN MARGIN requirement of Specification 3.1.1.1 is satisfied within 1 hour and be in at least HOT STANDRY within 6 hours.

b. With one full length CEA inoperable due to causes other than addressed by ACTION a, above, and inserted beyond the Long Term Steady State Insertion Limits hut within its above specified alianment requirements, operation in MODES 1 and 2 may continue pursuant to the recuirements of Specification 3.1 .3 .6 .

c. Wlith one full length C.EA inoperable due to causes other than addressed hy ACTION a, above, but within its above specified alianment requirements and eith:i fully withdrawn or with in the Long Term Steady State Insertion Limits if in full lenoth CEA group 6 , operation in MODFS 1 and ? may continue.

d. With one or more full length or part length CEAs misaligned from anv other C.EAs in its aroup by more than 7 inches but less than or equal to 19 inches, operation in MONES 1 and 2 may continue, provided that within one hour the misaligned C.EA(s) is either:

1. Restored to OPEPABLE status within its above specified alignment requirements, or

2. Declared inoperable and the SHUTDOWN MARGIN reauirement of Specification 3.1.1.1 is satisfied. After declaring the CEA inoperable, operation in MODES 1 and 2 may continue pursuant to the requirements of Specification 3.1.3.6 provided:

\footnotetext{
${ }^{\star}$ See Special Test Exceptions 3.10 .2 and 3.10.4.
} 
ACTION: (Continued)

a) Within one hour the remainder of the CEAs in the group with the inoperable CEA shall be aligned to within 7 inches of the inoperable CEA while maintaining the allowable CEA sequence and insertion limits shown on Figure 3.1-2; the THERMAL POWER level shall be restricted pursuant to Specification 3.1.3.6 during subsequent operation.

b) The SHUTDOWN MARGIN requirement of Specification 3.1.1.1 is determined at least once per 12 hours.

Otherwise, be in at least HOT STANDBY within 6 hours.

e. With one full length or part length CEA misaligned from any other CEA in its group by more than 19 inches, operation in MODES 1 and 2 may continue, provided that within one hour the misaligned CEA is either:

1. Restored to OPERABLE status within its above specified a) ignment requirements, or

2. Declared inoperable and the SHUTDOWN MARGIN requirement of Specification 3.1.1.1 is satisfied. After declaring the CEA inoperable, operation in MODES 1 and 2 may continue pursuant to the requirements of Specification 3.1.3.6 provided:

a) Within one hour the remainder of the CEAs in the group with the inoperable CEA shall be aligned to within 7 inches of the inoperable CEA while maintaining the allowable CEA sequence and insertion limits shown on Figure 3.1-2; the THERMAL POWER level shall be restricted pursuant to Specification 3.1.3.6 during subsequent operation.

b) The SHUTDOWN MARGIN requirement of Specification 3.1.1.1 is determined at least one per 12 hours.

Otherwise, be in at least HOT STANDBY within 6 hours.

f. With one part length CEA inoperable and inserted in the core, operation may continue provided the alignment of the inoperable part length CEA is maintained within 7 inches (indicated position) of all other part length CEAs in its group.

g. With more than one full length or part length CEA inoperable or misaligned from any other CEA in its group by more than 19 inches (indicated position), be in at least HOT STANDBY within 6 hours. 
4.1.3.1.1 The position of each full length and part length CEA shall he determined to he within 7 inches (indicated position) of all other CEAs in its group at least once per 12 hours except during time intervals when one CEAC. is inoperable or when both CEACs are inoperahle, then verify the individual CEA positions at least once per 4 hours.

4.1.3.1.2 Fach full length CEA not fully inserted and each part lenath CEA which is inserted in the core shall be determined to be OPERARLE by movement of at least 5 inches in any one direction at least once per 31 days. 
REACTIVITY CONTROL SYSTEMS

POSITION INDICATOR CHANNELS - OPERATING

LIMITING CONDITION FOR OPERATION

3.1.3.2 At least two of the following three CEA position indicator channels shall be OPERABLE for each CEA:

a. CEA Reed Switch Position Transmitter (RSPT 1) with the capability of determining the absolute CEA positions within 5 inches,

b. CEA Reed Switch Position Transmitter (RSPT 2) with the capability of determining the absolute CEA positions within 5 inches, and

c. The CEA pulse counting position indicator channel.

APPLICABILITY: MODES 1 and 2.

ACTION:

With a maximum of one CEA per CEA group having only one of the above required CEA position indicator channels OPERABLE, within 6 hours either:

a. Restore the inoperable position indicator channel to OPERABLE status, or

b. Be in at least HOT STANDBY, or

c. Position the CEA group(s) with the inoperable position indicator(s) at its fully withdrawn position while maintaining the requirements of Specifications 3.1.3.1 and 3.1.3.6. Operation may then continue provided the CEA group(s) with the inoperable position indicator(s) is maintained fully withdrawn, except during surveillance testing pursuant to the requirements of Specification 4.1.3.1.2, and each CEA in the group(s) is verified fully withdrawn at least once per 12 hours thereafter by its "Full Out" limit.

\section{SURVEILLANCE REQUIREMENTS}

4.1.3.2 Each of the above required position indicator channels shall be determined to be OPERABLE by verifying that for the same CEA, the position indicator channels agree within 5 inches of each other at least once per 12 hours. 
POSITION INDICATOR CHANNELS - SHUTDOWN

3.1.3.3 At least one CEA Reed Switch Position Transmitter indicator channel shall be OPERABLE for each shutdown, regulating or part length CEA not fully inserted.

APPLICABILITY: MODES $3^{*}, 4^{*}$ and $5^{*}$.

ACTION:

With less than the above required position indicator channel(s) OPERABLE, immediately open the reactor trip breakers.

4.1.3.3 Each of the above required CEA Reed Switch Position Transmitter indicator channel(s) shall be determined to be OPERABLE by performance of a CHANNEL FUNCTIONAL TEST at least once per 18 months.

With the reactor trip breakers in the closed position. 
CEA DROP TIME

LIMITING CONDITION FOR OPERATION

3.1.3.4 The individual full length (shutdown and control) CEA drop time, from a fully withdrawn position, shall be less than or equal to (3.0) seconds from when the electrical power is interrupted to the CEA drive mechanism until the CEA reaches its 90 percent insertion position with:

a. $T_{\text {avg }}$ greater than or equal to $(525)^{\circ} \mathrm{F}$, and

b. All reactor coolant pumps operating.

APPLICABILITY: MODES 1 and 2.

ACTION:

a. With the drop time of any full length CEA determined to exceed the above limit, restore the CEA drop time to within the above limit prior to proceeding to MODE 1 or 2.

b. With the CEA drop times within limits but determined at less than full reactor coolant flow, operation may proceed provided THERMAL POWER is restricted to less than or equal to the maximum THERMAL POWER level allowable for the reactor coolant pump combination operating at the time of CEA drop time determination.

4.1.3.4 The CEA drop time of full length CEAs shall be demonstrated through measurement prior to reactor criticality:

a. For all CEAs following each removal of the reactor vessel head,

b. For specifically affected individuals CEAs following any maintenance on or modification to the CEA drive system which could affect the drop time of those specific CEAs, and

c. At least once per 18 months. 
SHUTDOWN CEA INSERTION LIMIT

LIMITING CONDITION FOR OPERATION

3.1.3.5 All shutdown CEAs shall be withdrawn to the Full out position. APPLICABILITY: MODES 1 and $2^{*}$.

ACTION:

With a maximum of one shutdown CEA withdrawn to less than the Full out position, except for surveillance testing pursuant to Specification 4.1.3.1.2, within one hour either:

a. Withdraw the CEA to less than the Full out position, or

b. Declare the CEA inoperable and apply Specification (3.1.3.1).

4.1.3.5 Each shutdown CEA shall be determined to be withdrawn to the Full out position:

a. Within 15 minutes prior to withdrawal of any CEAs in regulating groups during an approach to reactor criticality, and

b. At least once per 12 hours thereafter.

${ }^{\star}$ See Special Test Exception 3.10.2.

\#With $K_{\text {eff }}$ greater than or equal to 1.0 . 
REGULATING CEA INSERTION LIMITS

3.1.3.6 The regulating CEA groups shall be 1 imited to the withdrawal sequence and to the insertion limits shown on Figure (3.1-2), with CEA insertion between the Long Term Steady State Insertion Limits and the Transient Insertion Limits restricted to:

a. Less than or equal to 4 hours per 24 hour interval,

b. Less than or equal to 5 Effective Full Power Days per 30 Effective Full Power Day interval, and

c. Less than or equal to 14 Effective Ful1 Power Days per calendar year.

\section{APPLICABILITY: MODES $\rceil^{*}$ and $2^{*} \#$.}

ACTION:

a. With the regulating CEA groups inserted beyond the Transient Insertion Limits, except for surveillance testing pursuant to Specification 4.1.3.1.2, within two hours either:

1. Restore the regulating CEA groups to within the limits, or

2. Reduce THERMAL POWER to less than or equal to that fraction of RATED THERMAL POWER which is allowed by the CEA group position using the above figure.

b. With the regulating CEA groups inserted between the Long Term Steady State Insertion Limits and the Transient Insertion Limits for intervals greater than 4 hours per 24 hour interval, operation may proceed provided either:

1. The Short Term Steady State Insertion Limits of Figure (3.1-2) are not exceeded, or

2. Any subsequent increase in THERMAL POWER is restricted to less than or equal to $5 \%$ of RATED THERMAL POWER per hour.

₹ See Special Test Exceptions 3.10.2 and 3.10.4.

\# With $k_{\text {eff }}$ greater than or equal to 1.0 . 
ACTION: (Continued)

c. With the regulating CEA groups inserted between the Long Term Steady State Insertion Limits and the Transient Insertion Limits for intervals greater than 5 EFPD per 30 EFPD interval or greater than 14 EFPD per calendar year, either:

1. Restore the regulating groups to within the Long Term Steady State Insertion Limits within two hours, or

2. Be in at least HOT STANDBY within 6 hours.

\section{SURVEILLANCE REQUIREMENTS}

4.1.3.6 The position of each regulating CEA group shall be determined to be within the Transient Insertion Limits at least once per 12 hours except during time intervals when the PDIL Auctioneer Alarm Circuit is inoperable, then verify the individual CEA positions at least once per 4 hours. The accumulated times during which the regulating CEA groups are inserted beyond the Long Term Steady State Insertion Limits but within the Transient Insertion Limits shall be determined at least once per 24 hours. 


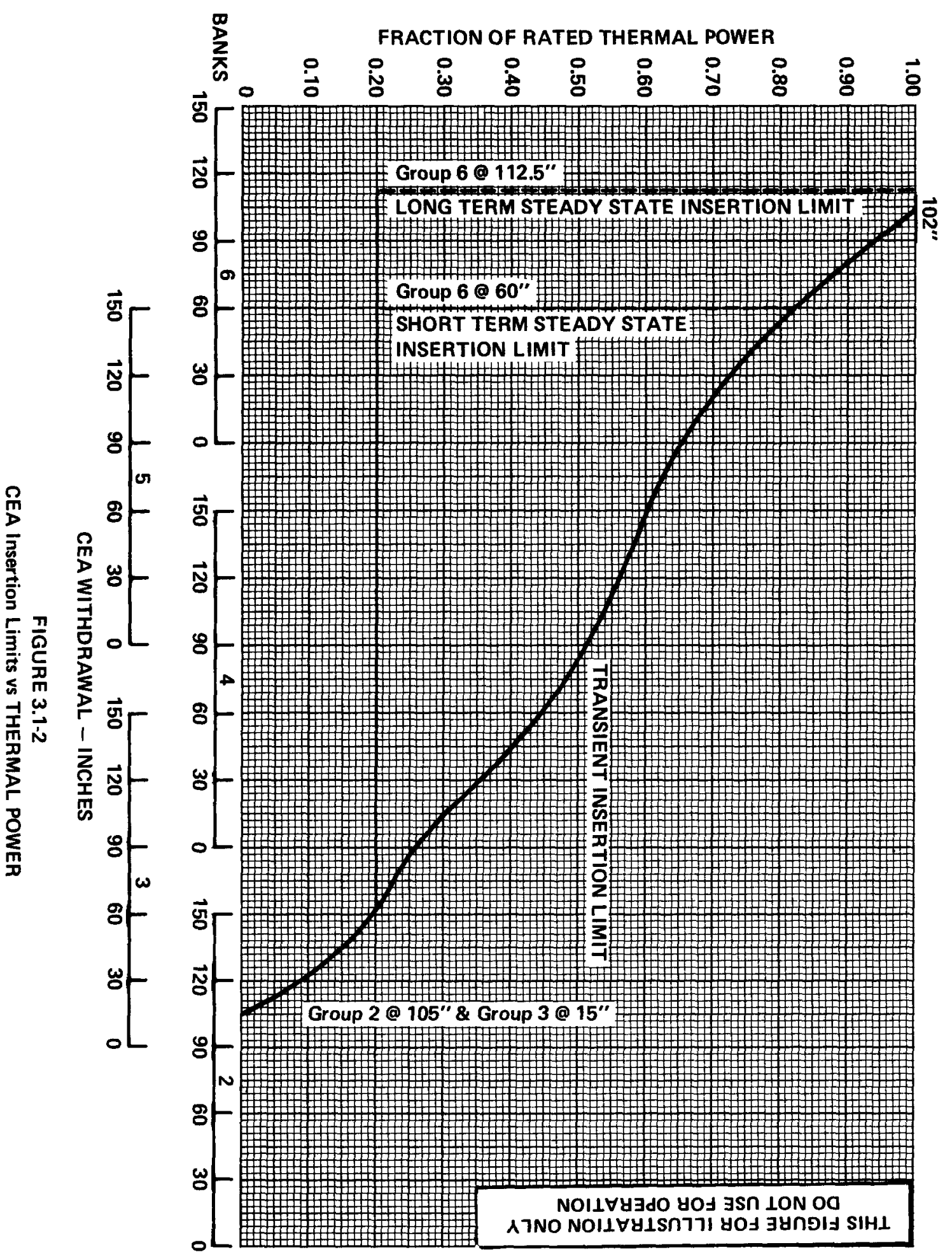


REACTIVITY CONTROL SYSTEMS

PART LENGTH CEA INSERTION LIMITS

LIMITING CONDITION FOR OPERATION

3.1.3.7 The position of the part length CEA group shall be restricted to prevent the neutron absorber section of the part length CEA group from covering any axial segment of the fuel assemblies for a period in excess of 7 out of any 30 EFPD period.

APPLICABILITY: MODES 1 and 2.

ACTION:

With the neutron absorber section of the part length CEA group covering any axial segment of the fuel assemblies for a period exceeding 7 out of any 30 EFPD period, either:

a. Reposition the part length CEA group to satisfy the above limit within 2 hours, or

b. Be in at least HOT STANDBY within the next 6 hours.

4.1.3.7 The position of the part length CEA group shall be determined at least once per 12 hours. 
REACTIVITY CONTROL SYSTEMS

PART LENGTH CEA INSERTION LIMITS (ALTERNATE if required by DNB considerations) LIMITING CONDITION FOR OPERATION

3.1.3.8 All part length CEAs shall be withdrawn to at least (176) steps. APPLICABILITY: MODES $1^{*}$ and $2^{*}$.

ACTION:

With a maximum of one PLCEA withdrawn to less than (176) steps, either:

a. Withdraw the PLCEA to at least (176) steps within one hour, or

b. Be in at least HOT STANDBY within the next 6 hours.

4.1.3.8 Each part length CEA shall be determined withdrawn to at least (176) steps by:

a. Verifying the positions of the PLCEAs prior to increasing THERMAL POWER above 5\% of RATED THERMAL POWER, and

b. Verifying, at least once per 31 days, that electric power has been disconnected from its drive mechanism by physical removal of a breaker from the circuit.

${ }^{\star}$ See Special Test Exception 3.10.2. 
3/4.2 POWER DISTRIBUTION LIMITS

$3 / 42.1$ LINEAR HEAT RATE

LIMITING CONDITION FOR OPERATION

3.2.1 The linear heat rate shall not exceed the limits shown on Figure 3.2-1.

APPLICABILITY: MODE 1 above (20)\% of RATED THERMAL POWER.

ACTION:

With the linear heat rate exceeding its limits, as indicated by either (1) the COLSS calculated core power exceeding the COLSS calculated core power operating limit based on $\mathrm{kw} / \mathrm{ft}$; or (2) when the COLSS is not being used, any OPERABLE Local Power Density channel exceeding the linear heat rate limit, within 15 minutes initiate corrective action to reduce the linear heat rate to within the limits and either:

a. Restore the linear heat rate to within its limits within one hour, or

b. Be in at least HOT STANDBY within the next 6 hours.

\section{SURVEILLANCE REQUIREMENTS}

4.2.1.1 The provisions of Specification 4.0.4 are not applicable.

4.2.1.2 The linear heat rate shall be determined to be within its limits when THERMAL POWER is above (20)\% of RATED THERMAL POWER by continuously monitoring the core power distribution with the Core Operating Limit Supervisory System (COLSS) or, with the COLSS out of service, by verifying at least once per 2 hours that the linear heat rate, as indicated on a 11 OPERABLE Local Power Density channels, is within the limit shown on Figure 3.2-1.

4.2.1.3 At least once per 31 days, the COLSS Margin Alarm shall be verified to actuate at a THERMAL POWER level less than or equal to the core power operating limit based on $\mathrm{kw} / \mathrm{ft}$. 
ח

$\stackrel{\omega}{\omega}$

$\stackrel{n}{n}$

$\stackrel{\sim}{N}$

$\frac{1}{3}$

16.0

뚱ํㅇ



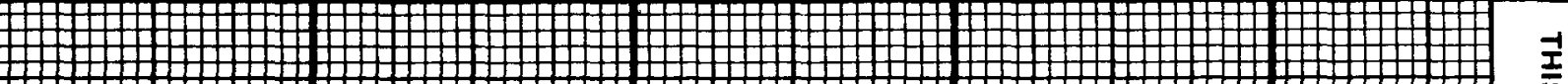
๖

\&2

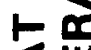

는

똥

a

$4+$

인

14

$\div 0$

ut

嵌至

电

3

15.0

๒



๓

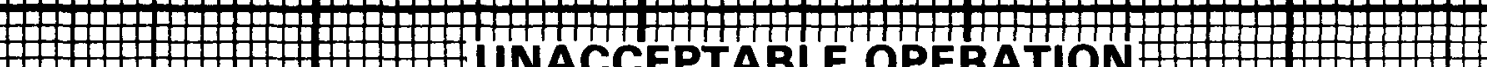

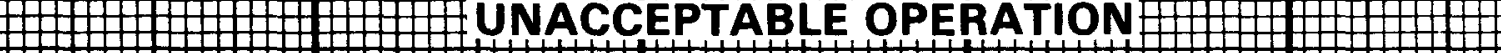

14.68

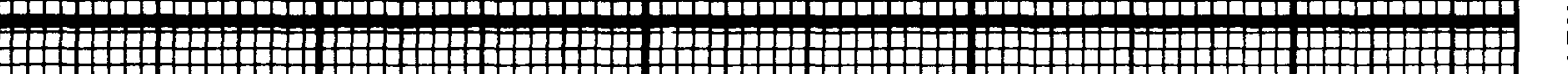

(

制

14.0





地







13.0

BOL

EOL

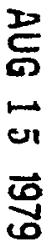

CYCLE LIFE

FIGURE 3.2-1 Allowable Peak Linear Heat Rate vs Burnup 
POWER DISTRIBUTION LIMITS

$3 / 4$ 2.2 RADIAL PEAKING FACTORS

LIMITING CONDITION FOR OPERATION

3.2.2 The measured planar radial peaking factors $\left(F_{r}^{m}\right)$ shall be less than or equal to the planar radial peaking factors $\left(F_{r}^{C}\right)$ used in the Core Operating Limit Supervisory System (COLSS) and in the Core Protection Calculators (CPC).

APPLICABILITY: MODE 1 above 20\% of RATED THERMAL POWER. *

\section{ACTION:}

With a $F_{r}^{m}$ exceeding a corresponding $F_{r}^{c}$, within 6 hours either:

a. Adjust the CPC addressable constants to increase the multiplier applied to planar radial peaking by a factor equivalent to greater than or equal to $F_{r}^{m} / F_{r}^{c}$ restrict subsequent operation so that a margin to the COLSS operating limits of at least $\left[\left(F_{r}^{m} / F_{r}^{c}\right)-1.0\right] \times 100 \%$ is maintained; or

b. Adjust the affected planar radial peaking factors $\left(F_{r}^{c}\right)$ used in the COLSS and CPC to a value greater than or equal to the measured planar radial peaking factors $\left(F_{r}^{m}\right)$ or

c. Be in at least HOT STANDBY.

\section{SURVEILANCE REQUIREMENTS}

4.2.2.1 The provisions of Specification 4.0.4 are not applicable.

4.2.2.2 The measured planar radial peaking factors $\left(F_{r}^{m}\right)$ obtained by using the incore detection system, shall be determined to be less than or equal to the planar radial peaking factors $\left(F_{r}^{C}\right)$, used in the COLSS and CPC at the following intervals:

a. After each fuel loading with THERMAL POWER greater than ( 40$) \%$ but prior to operation above (70)\% of RATED THERMAL POWER, and

b. At least once per 31 days of accumulated operation in MODE 1 .

ॠSee Special Test Exception 3.10.2. 
POWER DISTRIBUTION LIMITS

3/4 2.3 AZIMUTHAL POWER TILT - Tg

LIMITING CONDITION FOR OPERATION

3.2.3 The AZIMUTHAL POWER TILT ( $\left.T_{f}\right)$ shall be less than or equal to the AXIMUTHAL POWER TILT Allowance used in the cdre Protection Calculators (CPCs).

APPLICABILITY: MODE 1 above (20)\% of RATED THERMAL POWER. *

ACTION:

a. With the measured AZIMUTHAL POWER TILT determined to exceed the AZIMUTHAL POWER TILT Allowance used in the CPCS but less than or equal to 0.10 , within two hours either correct the power tilt or adjust the AZIMUTHAL POWER TILT Allowance used in the CPCS to greater than or equal to the measured value.

b. With the measured AZIMUTHAL POWER TILT determined to exceed 0.10:

1. Due to misalignment of either a part length or full length CEA, within 30 minutes verify that the Core Operating Limit Supervisory System (COLSS) (when COLSS is being used to monitor the core power distribution per Specifications 4.2 .1 and 4.2 .4 ) is detecting the CEA misalignment.

2. Verify that the AZIMUTHAL POWER TILT is within its limit within 2 hours after exceeding the 1 imit or reduce THERMAL POWER to less than (50)\% of RATED THERMAL POWER within the next 2 hours and reduce the Linear Power Level - High trip setpoints to less than or equal to $55 \%$ of RATED THERMAL POWER within the next 4 hours.

3. Identify and correct the cause of the out of limit condition prior to increasing THERMAL POWER; subsequent POWER OPERATION above (50)\% of RATED THERMAL POWER may proceed provided that the AZIMUTHAL POWER TILT is verified within its limit at least once per hour for 12 hours or until verified acceptable at (95)\% or greater RATED THERMAL POWER.

\footnotetext{
${ }^{\star}$ See Special Test Exception 3.10.2.
} 


\section{POWER DISTRIBUTION LIMITS}

SURVEILLANCE REQUIREMENTS

4.2.3 The AZIMUTHAL POWER TILT shall be determined to be within the limit above (20)\% of RATED THERMAL POWER by:
a. Continuously monitoring the tilt with COLSS when the COLSS is OPERABLE.
b. Calculating the tilt at least once per 12 hours when the COLSS is inoperable.
c. Verifying at least once per 31 days, that the COLSS Azimuthal Tilt Alarm is actuated at an AZIMUTHAL POWER TILT greater than the AZIMUTHAL POWER TILT Allowance used in the CPCs.
d. Using the incore detectors at least once per 31 days to independently confirm the validity of the COLSS calculated AZIMUTHAL POWER TILT.


3.2.4 The DNBR margin shall be maintained by operating within the region of acceptable operation of Figure $3.2-2$ or $3.2-3$, as applicable.

APPLICABILITY: MODE 1 above (20)\% of RATED THERMAL POWER.

ACTION:

With operation outside of the region of acceptable operation, as indicated by either (1) the COLSS calculated core power exceeding the COLSS calculated core power operating limit based on DNBR; or (2) when the COLSS is not being used, any OPERABLE Low DNBR channel exceeding the DNBR limit, within 15 minutes initiate corrective action to reduce the DNBR to within the limits and either:

a. Restore the DNBR to within its limits within one hour, or

b. Be in at least HOT STANDBY within the next 6 hours.

\section{SURVEILLANCE REQUIREMENTS}

\subsubsection{The provisions of Specification 4.0.4 are not applicable.}

4.2.4.2 The DNBR shall be determined to be within its limits when THERMAL POWER is above (20)\% of RATED THERMAL POWER by continuously monitoring the core power distribution with the Core Operating Limit Supervisory System (COLSS) or, with the COLSS out of service, by verifying at least once per 2 hours that the DNBR, as indicated on all OPERABLE DNBR channels, is within the limit shown on Figure 3.2-3.

4.2.4.3 At least once per 31 days, the COLSS Margin Alarm shall be verified to actuate at a THERMAL POWER level less than or equal to the core power operating limit based on DNBR. 
4.2.4.4 The following DNBR penalty factors shall be verified to be included in the COLSS and CPC DNBR calculations at least once per 31 days:

$\begin{array}{lc}\text { Burnup }\left(\frac{\mathrm{GWD}}{\mathrm{MTU}}\right) & \text { DNBR Penalty }(\%) \\ 0-3.1 & (0.0) \\ 3.1-5 & (2.0) \\ 5-10 & (5.9) \\ 10-15 & (8.8) \\ 15-20 & (11.4) \\ 20-25 & (13.6) \\ 25-30 & (15.6) \\ 30-35 & (17.4)\end{array}$




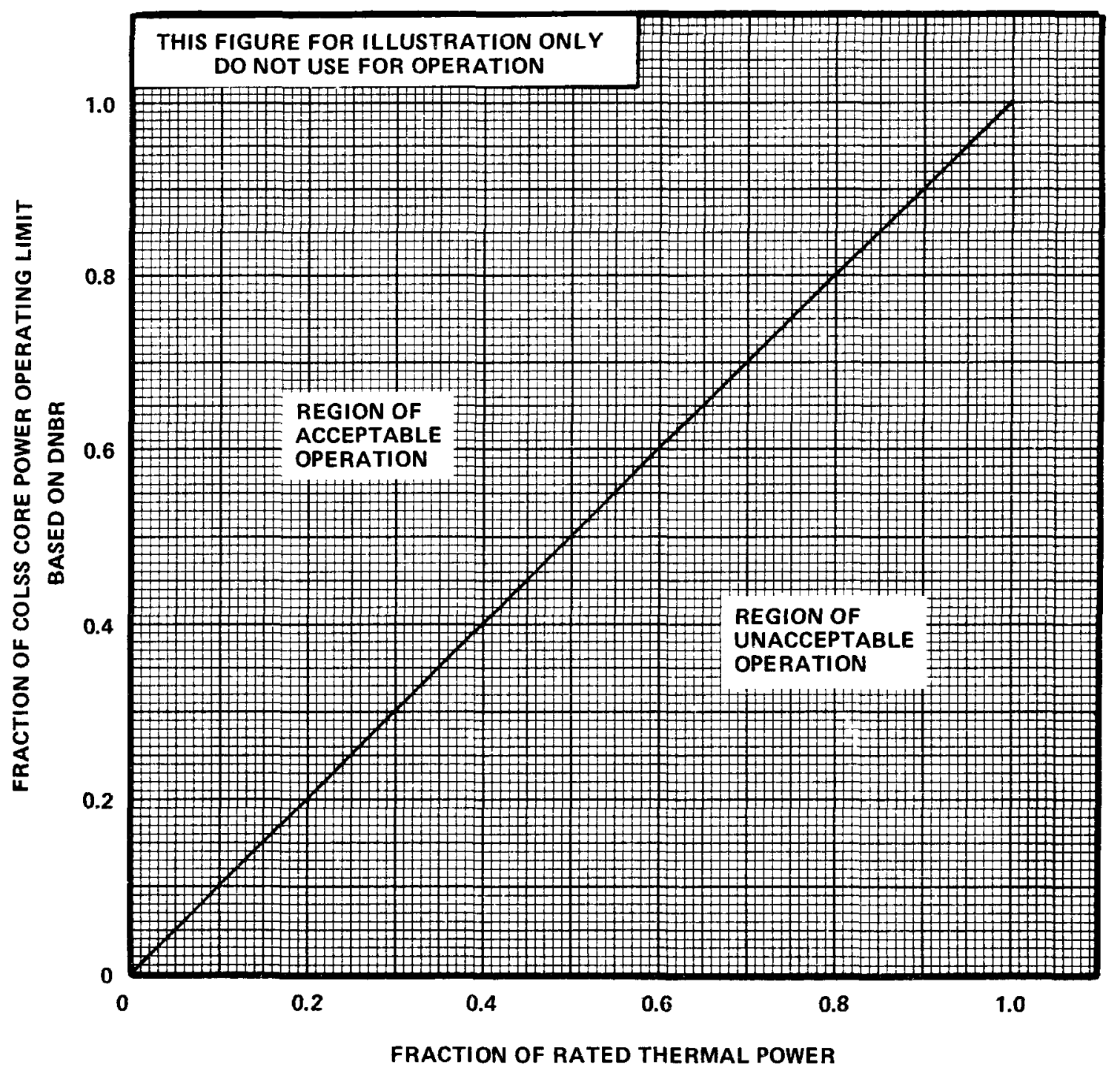

Figure 3.2-2

DNBR Margin Operating Limit Based on COLSS 


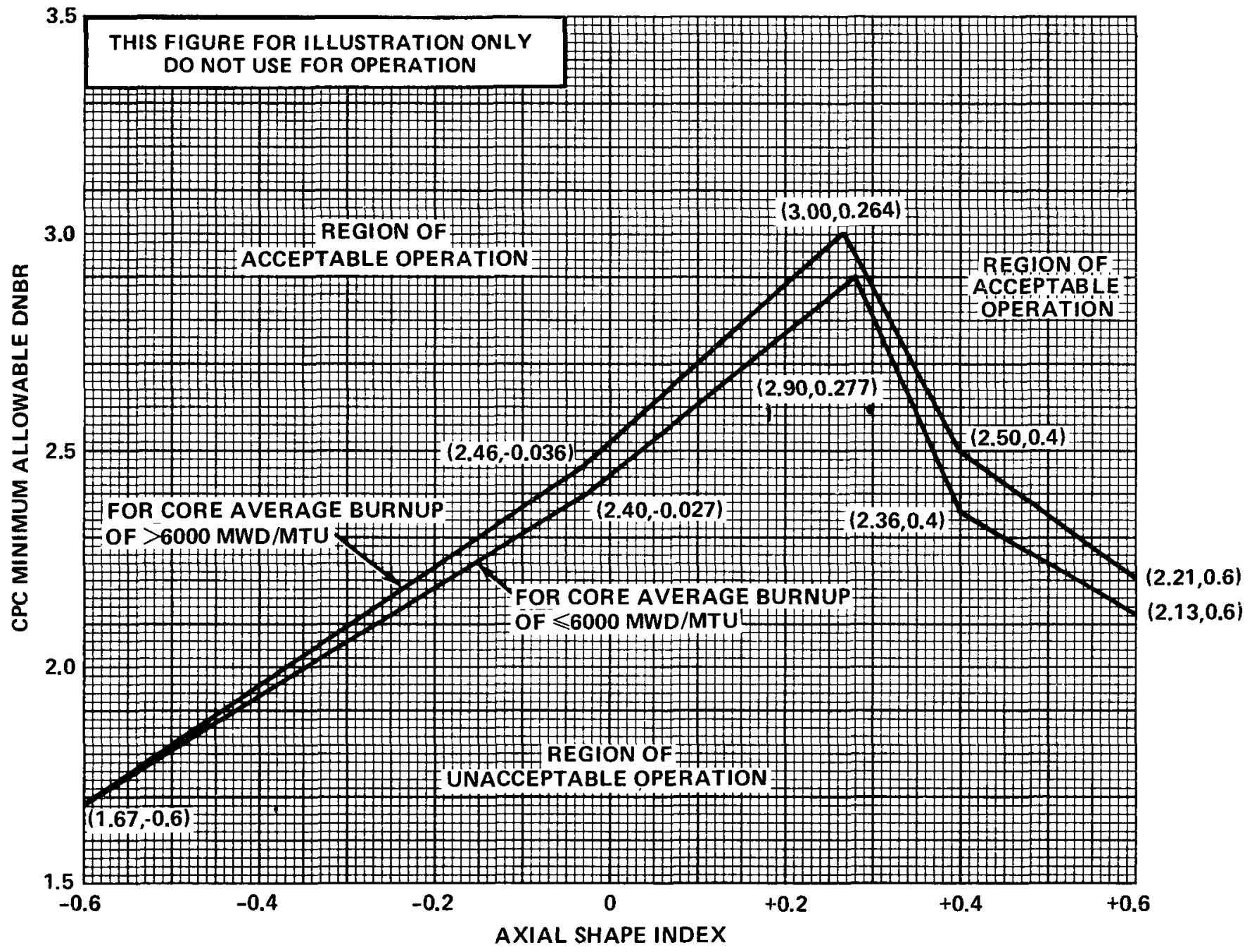

Figure 3.2-3

DNBR Margin Operating Limit Based on Core Protection Calculators (COLSS Out of Service) 
POWER DISTRIBUTION LIMITS

3/4.2.5 RCS FLOW RATE

LIMITING CONDITION FOR OPERATION

3.2.5 The actual Reactor Coolant System total flow rate shall be greater than or equal to $\left(120.4 \times 10^{6}\right) 1 \mathrm{bm} / \mathrm{hr}$.

APPLICABILITY: MODE 1 .

ACTION:

With the actual Reactor Coolant System total flow rate determined to be less than the above limit, reduce THERMAL POWER to less than $5 \%$ of RATED THERMAL POWER within the next 4 hours.

SURVEILLANCE REQUIREMENTS

4.2.5 The actual Reactor Coolant System total flow rate shall be determined to be within its limit at least once per 12 hours. 
POWER DISTRIBUTION LIMITS

3/4 2.6 CORE AVERAGE COOLANT TEMPERATURE

LIMITING CONDITION FOR OPERATION 3.2.6 The core average coolant temperature $\left(T_{\text {avg }}\right.$ ) shall be less than or equal
to $(588.2)^{\circ} \mathrm{F}$.

APPLICABILITY: MODE 1

ACTION:

With the core average coolant temperature exceeding its limit, restore the temperature to within its limit within 2 hours or reduce THERMAL POWER to less than 5\% of RATED THERMAL POWER within the next 4 hours.

SURVEILLANCE REQUIREMENTS

4.2.6 The core average coolant temperature shall be determined to be within its limit at least once per 12 hours. 

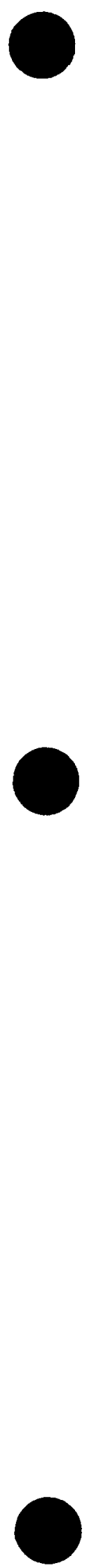


\section{$3 / 4.3$ INSTRUMENTATION}

3/4.3.1 REACTOR PROTECTIVE INSTRUMENTATION

\section{LIMITING CONDITION FOR OPERATION}

3.3.1 As a minimum, the reactor protective instrumentation channels and bypasses of Table 3.3-1 shal1 be OPERABLE with RESPONSE TIMES as shown in Table 3.3-2.

APPLICABILITY: As shown in Table 3.3-1.

\section{ACTION:}

As shown in Table 3.3-1.

\section{SURVEILLANCE REQUIREMENTS}

4.3.1.1 Each reactor protective instrumentation channel shall be demonstrated OPERABLE by the performance of the CHANNEL CHECK, CHANNEL CALIBRATION and CHANNEL FUNCTIONAL TEST operations for the MODES and at the frequencies shown in Table 4.3-1.

4.3.1.2 The logic for the bypasses shall be demonstrated OPERABLE prior to each reactor startup unless performed during the preceding 92 days. The total bypass function shall be demonstrated OPERABLE at least once per 18 months during CHANNEL CALIBRATION testing of each channel affected by bypass operation.

4.3.1.3 The REACTOR TRIP SYSTEM RESPONSE TIME of each reactor trip function shall be demonstrated to be within its limit at least once per 18 months. Each test shall include at least one channel per function such that all channels are tested at least once every $N$ times 18 months where $N$ is the total number of redundant channels in a specific reactor trip function as shown in the "Total No. of Channels" column of Table 3.3-1.

4.3.1.4 The isolation characteristics of each CEA isolation amplifier and each optical isolator for CEA Calculator to Core Protection Calculator data transfer shall be verified at least once per 18 months during the shutdown per the following tests:

a. For the CEA position isolation amplifiers:

1. With 120 volts $A C(60 \mathrm{~Hz})$ appiied for at least 30 seconds across the output, the reading on the input does not exceed (0.015) volts DC. 
2. With 120 volts $A C(60 \mathrm{~Hz})$ applied for at least 30 seconds across the input, the reading on the output does not exceed (8) volts DC.

b. For the optical isolators: Verify that the input to output insulation resistance is greater than (10) megohms when tested using a megohmmeter on the 500 volt DC range.

4.3.1.5 The Core Protection Calculator System shall be determined OPERABLE at least once per 12 hours by verifying that less than three auto restarts have occurred on each calculator during the past 12 hours. 
TABLE 3.3-1

$n$
1
$n$
$n$

REACTOR PROTECTIVE INSTRUMENTATION

\section{FUNCTIONAL UNIT}

1. Manua1 Reactor Trip

2. Linear Power Level - High

3. Logarithmic Power Level-High

a. Startup and Operating b. Shutdown

4. Pressurizer Pressure - High

$\stackrel{\omega}{\omega}$

5. Pressurizer Pressure - Low

6. Containment Pressure - High

ஸे

7. Steam Generator Pressure - Low

8. Steam Generator Level - Low

9. Local Power Density - High

10. DNBR - LOW

11. Steam Generator Level - High

12. Reactor Protection System Logic

₹ 13. Reactor Trip Breakers

$\varpi$ 14. Core Protection Calculators

$\overrightarrow{0}$ 15. CEA Calculators

\section{TOTAL NO. OF CHANNELS}

2

4

$\begin{array}{ll}4 & 2(a)(d) \\ 4 & 0 \\ 4 & 2 \\ 4 & 2(b) \\ 4 & 2 \\ 4 / S G & 2 / S G \\ 4 / S G & 2 / S G \\ 4 & 2(c)(d) \\ 4 & 2(c)(d) \\ 4 / S G & 2 / S G \\ 2 & 1 \\ 2 & 1 \\ 4 & 2(c)(d) \\ 2 & 1\end{array}$

\section{MINIMUM}

CHANNELS

OPERABLE

2

3

(

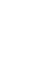

3
3
3
3
3
3
3
3
$3 / 5$

3
2

3

3

3

$3 / S G$

$3 / S G$

, 2

1,2

1, 2 and *

$3,4,5$

2\#

1,2

1,2

1,2

1,2

MODES

ACTION

2 and *

1

2\#

3

1,2

1,2

1, 2 and *

1,2 and *

1,2

1,2

2(e)

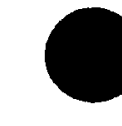




\section{TABLE $3.3-1$ (Continued)}

\section{TABLE NOTATION}

* With the protective system trip breakers in the closed position, the CEA drive system capable of CEA withdrawal, and fuel in the reactor vessel.

\#The provisions of Specification 3.0.4 are not applicable.

(a) Trip may be manually bypassed above $\left(10^{-4}\right) \%$ of RATED THERMAL POWER; bypass shal1_ be automatically removed when THERMAL POWER is less than or equal to $\left(10^{-4}\right) \%$ of RATED THERMAL POWER.

(b) Trip may be manually bypassed below (400) psia; bypass shall be automatically removed whenever pressurizer pressure is greater than or equal to 500 psia.

(c) Trip may be manually bypassed below $\left(10^{-4}\right) \%$ of RATED THERMAL POWER; bypass shall be automatically removed when THERMAL POWER is greater than or equal to $\left(10^{-4}\right) \%$ of RATED THERMAL POWER. During testing pursuant to Special Test Exception 3.10.3, trip may be manually bypassed below (I)\% of RATED THERMAL POWER; bypass shall be automatically removed when THERMAL POWER is greater than or equal to (1)\% of RATED THERMAL POWER.

(d) Trip may be bypassed during testing pursuant to Special Test Exception 3. 10.3.

(e) See Special Test Exception 3.10.2.

(f) Each channel shall be comprised of two trip breakers; actual trip logic shall be one-out-of-two taken twice.

\section{ACTION STATEMENTS}

ACTION 1 - with the number of channels OPERABLE one less than required by the Minimum Channels OPERABLE requirement, restore the inoperabie channel to OPERABLE status within 48 hours or be in at least HOT STANDBY within the next 6 hours and/or open the protective system trip breakers.

ACTION 2 - With the number of channels OPERABLE one less than the Total Number of Channels, STARTUP and/or POWER OPERATION may proceed provided the following conditions are satisfied:

a. The inoperable channel is placed in the tripped condition within 1 hour. 
TABLE 3.3-1 (Continued)

\section{ACTION STATEMENTS}

b. All functional units receiving an input from the tripped channel are also placed in the tripped condition within 1 hour.

c. The Minimum Channels OPERABLE requirement is met; however, one additional channel may be bypassed for up to 2 hours for surveillance testing per Specification 4.3.1.1.

ACTION 3 - With the number of channels OPERABLE one less than required by the Minimum Channels OPERABLE requirement, verify compliance with the SHUTDOWN MARGIN requirements of Specification 3.1 .1 .1 or 3.1.1.2, as applicable, within 1 hour and at least once per 12 hours thereafter.

ACTION 4 - With the number of channels OPERABLE one less than required by the Minimum Channels OPERABLE requirement, be in at least HOT STANDBY within 6 hours; however, one channel may be bypassed for up to 1 hour for surveillance testing per Specification 4.3.1.1.

ACTION 5 - a. With one CEAC inoperable, operation may continue for up to 7 days provided that at least once per 4 hours, each CEA is verified to be within 7 inches (indicated position) of a) 1 other CEAs in its group.

b. With both CEACs inoperable, operation may continue provided that:

1. Within 1 hour the margins required by Specifications 3.2.1 and 3.2.4 are increased and maintained at a value equivalent to greater than or equal to $8 \%$ of RATED THERMAL POWER.

2. Within 4 hours:

a) A11 fu11 length and part length CEA groups are withdrawn to and subsequently maintained at the "Full Out" position, except during surveillance testing pursuant to the requirements of Specification 4.1.3.1.2 or for control when CEA group 6 may be inserted no further than 127.5 inches withdrawn.

b) The "RSPT/CEAC Inoperable" addressable constant in the CPCs is set to the inoperable status. 


\section{TABLE 3.3-1 (Continued)}

\section{ACTION STATEMENTS}

c) The Control Element Drive Mechanism Control System (CEDMCS) is placed in and subsequently maintained in the "Off" mode except during CEA group 6 motion permitted by a) above, when the CEDMCS may be operated in either the "Manual Group" or "Manual Individual" mode.

3. At least once per 4 hours, all full length and part length CEAs are verified fully withdrawn except during surveillance testing pursuant to Specification 4.1.3.1.2 or during insertion of CEA group 6 as permitted by 1 . a) above, then verify at least once per 4 hours that the inserted CEAs are aligned within 7 inches (indicated position) of all other CEAs in its group.

ACTION 6 - With three or more auto restarts of one non-bypassed calculator during a 12-hour interval, demonstrate calculator OPERABILITY by performing a CHANNEL FUNCTIONAL TEST within the next 24 hours. 


\section{REACTOR PROTECTIVE INSTRUMENTATION RESPONSE TIMES}

\section{FUNCTIONAL UNIT}

1. Manual Reactor Trip

2. Linear Power Leve1 - High

3. Logarithmic Power Level - High

4. Pressurizer Pressure - High

5. Pressurizer Pressure - Low

6. Containment Pressure - High

$\underset{\omega}{\omega}$ 7. Steam Generator Pressure - Low

$\stackrel{\omega}{i}$ 8. Steam Generator Level - Low

9. Local Power Density - High

a. Neutron Flux Power from Excore Neutron Detectors

b. CEA Positions

10. DNBR - LoW

a. Neutron Flux Power from Excore Neutron Detectors

b. CEA Positions

c. Cold Leg Temperature

d. Hot Leg Temperature

ᄅ e. Primary Coolant Pump Shaft Speed

$\mapsto$

f. Reactor Coolant Pressure from Pressurizer

\section{RESPONSE TIME}

Not Applicable

$\leq$ seconds*

$\leq$ seconds*

$\leq$ seconds

$\leq$ seconds

$\leq$ seconds

$\leq$ seconds

$\leq$ seconds

$\leq$ seconds* seconds ${ }^{\star *}$

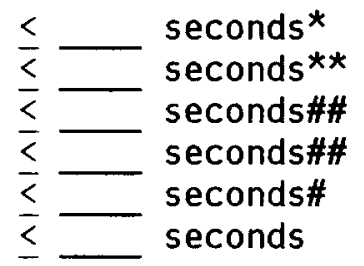




\section{REACTOR PROTECTIVE INSTRUMENTATION RESPONSE TIMES}

\section{FUNCTIONAL UNIT}

11. Steam Generator Leve1 - High

12. Reactor Protection System Logic

13. Reactor Trip Breakers

14. Core Protection Calculators

15. CEA Calculators

\section{RESPONSE TIME}

Not Applicable

Not Applicable

Not Applicable

Not Applicable

Not Applicable

Neutron detectors are exempt from response time testing. Response time of the neutron flux signal portion of the channel shall be measured from detector output or input of first electronic component in channel. (This provision is not applicable to CP's docketed after January 1, 1978. See Regulatory Guide 1.118, November 1977.)

**Response time shall be measured from the onset of a single CEA drop.

\# Response time shall be measured from the onset of a 2 out of 4 Reactor Coolant Pump coastdown.

\#\# Based on a resistance temperature detector (RTD) response time of less than or equal to 6.0 seconds where the RTD response time is equivalent to the time interval required for the RTD output to achieve $63.2 \%$ of its total change when subjected to a step change in RTD temperature. 
TABLE 4.3-1

\section{REACTOR PROTECTIVE INSTRUMENTATION SURVEILLANCE REQUIREMENTS}

\section{FUNCTIONAL UNIT}

1. Manual Reactor Trip

2. Linear Power Level - High

3. Logarithmic Power Level - High

4. Pressurizer Pressure - High

$\stackrel{\omega}{\infty}$ 5. Pressurizer Pressure - Low

w 6 . Containment Pressure - High

7. Steam Generator Pressure - Low

8. Steam Generator Level - Low

9. Local Power Density - High

10. DNBR - LOW

ह
ज
$\overrightarrow{0}$
जै

\begin{tabular}{|c|c|c|c|}
\hline $\begin{array}{l}\text { CHANNEL } \\
\text { CHECK }\end{array}$ & $\begin{array}{c}\text { CHANNEL } \\
\text { CALIBRATION } \\
\end{array}$ & $\begin{array}{l}\text { CHANNEL } \\
\text { FUNCTIONAL } \\
\text { TEST } \\
\end{array}$ & $\begin{array}{c}\text { MODES IN WHICH } \\
\text { SURVEILLANCE } \\
\text { REQUIRED } \\
\end{array}$ \\
\hline N.A. & N.A. & $S / U(1)$ & N.A. \\
\hline S & $\begin{array}{l}D(2,4), M(3,4), \\
Q(4)\end{array}$ & M & 1,2 \\
\hline$S$ & $R(4)$ & $M$ and $S / U(1)$ & $1,2,3,4$, \\
\hline$S$ & $\mathrm{R}$ & M & 1,2 \\
\hline$S$ & $\mathrm{R}$ & M & 1,2 \\
\hline$S$ & $\mathrm{R}$ & M & 1,2 \\
\hline$S$ & $\mathrm{R}$ & M & 1,2 \\
\hline$S$ & $\mathrm{R}$ & M & 1,2 \\
\hline$S$ & $D(2,4), R(4,5)$ & $M, R(6)$ & 1,2 \\
\hline$S$ & $\begin{array}{l}S(7), D(2,4), \\
M(8), R(4,5)\end{array}$ & $M, R(6)$ & 1,2 \\
\hline S & $\mathrm{R}$ & M & 1,2 \\
\hline N. A. & N.A. & M & 1,2 and $*$ \\
\hline
\end{tabular}


TABLE 4.3-1 (Continued)

$\stackrel{\substack{1 \\ 1}}{\sim}$

\section{REACTOR PROTECTIVE INSTRUMENTATION SURVEILLANCE REQUIREMENTS}

\section{FUNCTIONAL UNIT}

13. Reactor Trip Breakers

14. Core Protection Calculators

15. CEA Calculators

\begin{tabular}{|c|c|}
\hline $\begin{array}{l}\text { CHANNEL } \\
\text { CHECK }\end{array}$ & $\begin{array}{c}\text { CHANNEL } \\
\text { CALIBRATION }\end{array}$ \\
\hline
\end{tabular}

N. A.

S

S

N.A.

$\mathrm{R}$
CHANNEL FUNCTIONAL

TEST

$D(2,4), R(4,5)$
MODES IN WHICH SURVEILLANCE REQUIRED

1, 2 and *

1,2

1,2

$\omega$
$\stackrel{\omega}{\omega}$
1
$\stackrel{5}{\circ}$

है
e
छூ 
TABLE 4.3-1 (Continued)

TABLE NOTATION

* - With reactor trip breakers in the closed position and the CEA drive system capable of CEA withdrawal.

(1) - If not performed in previous 7 days.

(2) - Heat balance only (CHANNEL FUNCTIONAL TEST not included), above $15 \%$ of RATED THERMAL POWER; adjust the Linear Power Level signals and the CPC addressable constant multipliers to make the CPC delta $T$ power and CPC nuclear power calculations agree with the calorimetric calculation if absolute difference is greater than $2 \%$. During PHYSICS TESTS, these daily calibrations may be suspended provided these calibrations are performed upon reaching each major test power plateau and prior to proceeding to the next major test power plateau.

(3) - Above $15 \%$ of RATED THERMAL POWER, verify that the 1 inear power subchannel gains of the excore detectors are consistent with the values used to establish the shape annealing matrix elements in the Core Protection Calculators.

(4) - Neutron detectors may be excluded from CHANNEL CALIBRATION.

(5) - After each fuel loading and prior to exceeding $70 \%$ of RATED THERMAL POWER, the incore detectors shall be used to determine the shape annealing matrix elements and the Core Protection Calculators shall use these elements.

(6) - This CHANNEL FUNCTIONAL TEST shall include the injection of simulated process signals into the channel as close to the sensors as practicable to verify OPERABILITY including alarm and/or trip functions.

(7) - Above $70 \%$ of RATED THERMAL POWER, verify that the total RCS flow rate as indicated by each CPC is less than or equal to the actual RCS total flow rate determined by either using the reactor coolant pump differential pressure instrumentation (conservatively compensated for measurement uncertainties) or by calorimetric calculations (conservatively compensated for measurement uncertainties) and if necessary, adjust the CPC addressable constant flow coefficients such that each CPC indicated flow is less than or equal to the actual flow rate. The flow measurement uncertainty may be included in the BERRI term in the CPC and is equal to or greater than $4 \%$.

(8) - Above $70 \%$ of RATED THERMAL POWER, verify that the total RCS flow rate as indicated by each CPC is less than or equal to the actual RCS total flow rate determined by calorimetric calculations (conservatively compensated for measurement uncertainties). 
INSTRUMENTATION

\section{3/4.3.2 ENGINEERED SAFETY FEATURE ACTUATION SYSTEM INSTRUMENTATION}

\section{LIMITING CONDITION FOR OPERATION}

3.3.2 The Engineered Safety Feature Actuation System (ESFAS) instrumentation channels and bypasses shown in Table 3.3-3 shall be OPERABLE with their trip setpoints set consistent with the values shown in the Trip Setpoint column of Table 3.3-4 and with RESPONSE TIMES as shown in Table 3.3-5.

APPLICABILITY: As shown in Table 3.3-3.

ACTION:

a. With an ESFAS instrumentation channel trip setpoint less conservative than the value shown in the Allowable Values column of Table 3.3-4, declare the channel inoperable and apply the applicable ACTION requirement of Table 3.3-3 until the channel is restored to OPERABLE status with the trip setpoint adjusted consistent with the Trip Setpoint value.

b. With an ESFAS instrumentation channel inoperable, take the ACTION shown in Table 3.3-3.

4.3.2.1 Each ESFAS instrumentation channel shall be demonstrated OPERABLE by the performance of the CHANNEL CHECK, CHANNEL CALIBRATION and CHANNEL FUNCTIONAL TEST operations for the MODES and at the frequencies shown in Table 4.3-2.

4.3.2.2 The logic for the bypasses shall be demonstrated OPERABLE during the at power CHANNEL FUNCTIONAL TEST of channels affected by bypass operation. The total bypass function shall be demonstrated OPERABLE at least once per 18 months during CHANNEL CALIBRATION testing of each channel affected by bypass operation.

4.3.2.3 The ENGINEERED SAFETY FEATURES RESPONSE TIME of each ESFAS function shall be demonstrated to be within the limit at least once per 18 months. Each test shall include at least one channel per function such that all channels are tested at least once every $N$ times 18 . months where $N$ is the total number of redundant channels in a specific ESFAS function as shown in the "Total No. of Channels" Column of Table 3.3-3. 
TABLE $3 \cdot 3-3$

苗

\section{ENGINEERED SAFETY FEATURE ACTUATION SYSTEM INSTRUMENTATION}

FUNCTIONAL UNIT

\begin{tabular}{cl} 
TOTAL NO. & CHANNELS \\
OF CHANNELS & TO TRIP \\
\hline
\end{tabular}

MINIMUM

CHANNELS

OPERABLE

APPLICABLE MODES

ACTION

1. SAFETY INJECTION (SIAS)

Aanual (Trip Buttons)

2

1

2

$1,2,3,4 \quad 7$

b. Containment Pressure High

$1,2,3$

c. Pressurizer Pressure Low

$1,2,3(a) \quad 8^{*}$

2. CONTAINMENT SPRAY (CSAS)

a. Manual (Trip Buttons)

1

2

$1,2,3,4 \quad 7$

b. Containment Pressure -$\mathrm{High}$ - High

$1,2,3$

3. CONTAINMENT ISOLATION (CIAS)
a. Manual CIAS (Trip Buttons)

b. Manual SIAS (Trip Buttons)

c. Containment Pressure High

$1,2,3$

d. Pressurizer Pressure -

er

$\vec{\omega}$ 
TABLE 3.3-3 (Continued)

\section{ENGINEERED SAFETY FEATURE ACTUATION SYSTEM INSTRUMENTATION}

\section{FUNCTIONAL UNIT}

4. MAIN STEAM LINE

ISOLATION

a. Manual (Trip

$$
\text { Buttons) }
$$

b. Steam Generator

$$
\text { Pressure - Low }
$$

\begin{tabular}{cl} 
TOTAL NO. & CHANNELS \\
OF CHANNELS & TO TRIP \\
\hline
\end{tabular}

$\begin{array}{ll}2 / \text { steam } & 1 / \text { steam } \\ \text { generator } & \text { generator }\end{array}$

$4 /$ steam generator

\section{$2 /$ steam} generator

\section{MINIMUM}

CHANNELS

OPERABLE

APPLICABLE MODES

ACTION

$\stackrel{\omega}{\omega}$ 5. SHIELD BUILDING FILTRATION

$$
\text { (SBFAS) }
$$

a. Manual SBFAS (Trip Buttons)

b. Manual SIAS (Trip

$$
\text { Buttons) }
$$

2

1

$1,2,3,4 \quad 7$

c. Containment Pressure High

$1,2,3$

d. Pressurizer Pressure Low

6. CONTAINMENT SUMP RECIRCULATION (SRAS)

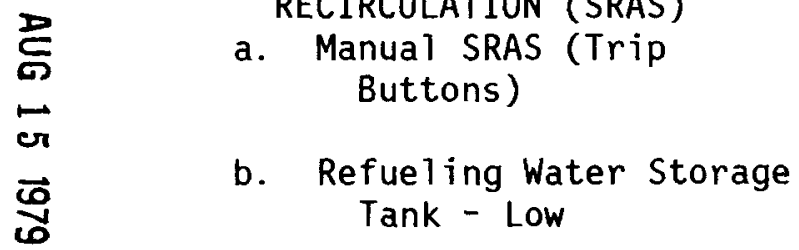


TABLE 3.3-3 (Continued)

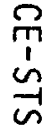

\section{ENGINEERED SAFETY FEATURE ACTUATION SYSTEM INSTUMENTATION}

FUNCTIONAL UNIT

APPLICABLE

OPERABLE

MODES

ACTION

7. CONTAINMENT PURGE

VALVES ISOLATION

a. Manual (Purge Valve Control Switches)

Manual CIAS (Trip Buttons)

2

1

2

$1,2,3,4 \quad 7$

c. Manual SIAS (Trip Buttons)

2

1

2

$1,2,3,4 \quad 7$

$\omega$
$\omega$
$\omega$
$\omega$

d. Automatic CIAS Actuation Logic

1

2

$1,2,3$

7

e. Containment Radiation High

Gaseous Monitor Particulate Monitor

Area Monitor

(1)

(1)

(1)

(1)

$1,2,3,4$

$1,2,3,4$

$1,2,3,4$

8. CONTAINMENT COOLING (CCAS)

a. Manual (Trip Buttons)

2 sets of $2 \quad 1$ set of 2

2 sets of 2

$1,2,3,4 \quad 7$

b. Containment Pressure High

4

2

3

$1,2,3$,

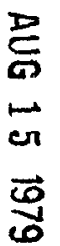

c. Pressurizer Pressure Low

4

2

3

$1,2,3(a) \quad 8$ 
TABLE 3.3-3 (Continued)

ENGINEERED SAFETY FEATURE ACTUATION SYSTEM INSTUMENTATION

\section{FUNCTIONAL UNIT}

9. LOSS OF POWER

a. 4.16 kv Emergency Bus Undervoltage (Loss of Voltage)

4/Bus

2/Bus

3/Bus

$1,2,3$

7

b. $4.16 \mathrm{kv}$ Emergency Bus Undervoltage (Degraded Voltage)

$\omega$
$\omega$
$\omega$
$\omega$

10. EMERGENCY FEEDWATER (EFAS)

a. Manual (Trip Buttons)

4/Bus

2/Bus

3/Bus

$1,2,3$

7

2 sets of $2 \quad 1$ set of 2 per $S / G$ per $S / G$

2 sets of 2 per $S / G$

b. SG Level and Pressure $(A / B)$ - Low and $\Delta P(A / B)$ - High

c. SG Leve1 (A/B) - Low and No $S / G$ Pressure Low Trip (A/B)
CHANNELS

APPLICABLE

MODES

ACTION 


\section{TABLE 3.3-3 (Continued)}

\section{TABLE NOTATION}

(a) Trip function may be bypassed in this MODE when pressurizer pressure is less than (400) psia; bypass shall be automatically removed when pressurizer pressure is greater than or equal to (500) psia.

(b) An SIAS signal is first necessary to enable CSAS logic.

(c) Trip function may be bypassed in this MODE helow (600) psia; bypass shall be automatically removed at or above (600) psia.

* The provisions of Specification 3.0.4 are not applicable.

\section{ACTION STATEMENTS}

ACTION 7 - With the number of OPERABLE channels one less than the Total Number of Channels, restore the inoperable channel to OPERABLE status within 48 hours or be in at least HOT STANDBY within the next 6 hours and in COLD SHUTDOWN within the following 30 hours.

ACTION 8 - With the number of OPERABLE channels one less than the Total Number of Channe1s, operation may proceed provided the following conditions are satisfied:

a. The inoperable channel is placed in the tripped condition within 1 hour.

b. All functional units receiving an input from the tripped channel are also placed in the tripped condition within 1 hour.

c. The Minimum Channels OPERABLE requirement is met; however, one additional channel may be bypassed for up to 2 hours for surveillance testing per Specification 4.3.2.1.

ACTION 9 - With less than the Minimum Channels OPERABLE, operation may continue provided the containment purge valves are maintained closed.

ACTION 10 - With the number of OPERABLE Channels one less than the Total Number of Channels, operation may proceed provided the inoperable channel is placed in the bypassed condition and the Minimum Channels OPERABLE requirement is demonstrated within 1 hour; one additional channel may be bypassed for up to 2 hours for surveillance testing per Specification 4.3.2.1. 


\section{FUNCTIONAL UNIT}

1. SAFETY INJECTION (SIAS)
a. Manual (Trip Buttons)
b. Containment Pressure - High
c. Pressurizer Pressure - Low

2. CONTAINMENT SPRAY (CSAS)
a. Manual (Trip Buttons)
b. Containment Pressure -- High-High
Not Applicable
$\leq(23.3)$ psia

3. CONTAINMENT ISOLATION (CIAS)
a. Manual CIAS (Trip Buttons)
b. Manual SIAS (Trip Buttons)
c. Containment Pressure - High
d. Pressurizer Pressure - Low
Not Applicable
Not Applicable
$\leq(18.4)$ psia
$\geq(1740)$ psia

4. MAIN STEAM LINE ISOLATION

a. Manual (Trip Buttons)

b. Steam Generator Pressure - Low

\section{TRIP SETPOINT}

Not Applicable

$\leq(18.4)$ psia

$\geq(1740)$ psia

Not Applicable

$\geq(500)$ psia
ALLOWABLE VALUES

Not Applicable

$\leq(19.02) \mathrm{psia} \cdot$

$\geq(1686.7)$ psia

Not Applicable

$\leq(23.62)$ psia

Not Applicable Not Applicable

$\leq(19.02)$ psia

$\geq(1686.7)$ psia

Not Applicable

$\geq$ (495) psia

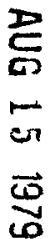


TABLE 3.3-4 (Continued)

$\stackrel{P}{1}$
$\stackrel{4}{n}$

\section{FUNCTIONAL UNIT}

5. SHIELD BUILDING FILTRATION (SBFAS)
a. Manual SBFAS (Trip Buttons)
b. Manual SIAS (Trip Buttons)
c. Containment Pressure - High
d. Pressurizer Pressure - Low
e. Containment Radiation - High
1. Gaseous Monitor
2. Particulate Monitor
3. Area Monitor

$\omega$
$\omega$
$\omega$
$\omega$
$\omega$

6. CONTAINMENT SUMP RECIRCULATION (SRAS)
a. Manual SRAS (Trip Buttons)
b. Refueling Water Storage Tank - Low

7. CONTAINMENT PURGE VALVES ISOLATION (CPAS)
a. Manual (Purge Valve Control Switches)

b. Manual CIAS (Trip Buttons)

c. Manual SIAS (Trip Buttons)

d. Automatic CIAS Actuation Logic

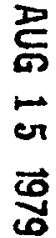

\section{TRIP VALUE}

Not Applicable

Not Applicable

$\leq$ (18.4) psia

$\geq(1740)$ psia

$<$ (2x background)

$\leq$ ( $2 x$ background $)$

$\leq$ ( $2 x$ background $)$

Not Applicable

(30) inches above tank bottom

Not Applicable

Not Applicable

Not Applicable

Not Applicable

$\leq$ (2x background)

$\leq$ (2x background)

$\leq$ ( $2 x$ background $)$
ALLOWABLE

VALUES

Not Applicable Not Applicable $\leq$ (19.02) psia $\geq(1686.7)$ psia

$<$ ( $2 x$ background)

$\leq$ ( $2 x$ background $)$

$\leq$ ( $2 x$ background $)$

Not Applicable

(24) inches above tank bottom

Not Applicable Not Applicable Not Applicable Not Applicable

$\leq$ (2x background $)$ $\leq$ ( $2 x$ background) $\leq$ (2x background $)$ 
FUNCTIONAL UNIT

8. CONTAINMENT COOLING (CCAS)
a. Manual (Trip Buttons)
b. Containment Pressure - High
c. Pressurizer Pressure - Low
Not Applicable
$\leq(18.4)$ psia
$\geq(1740)$ psia

9. LOSS OF POWER
a. $\quad 4.16 \mathrm{kv}$ Emergency Bus Undervoltage (Loss of Voltage)
(3120) volts
$(423) \pm(2.0)$ volts with an $(8.0+0.5)$ second time dêlay

$\overrightarrow{0}$

\section{TRIP VALUE}

Not Applicable

$\geq(46.5) \%$

$\leq$ (39) psi

$\leq$ (39) psi

$\geq(728)$ psia
ALLOWABLE VALUES

Not Applicable

$\leq$ (19.02) psia

$\geq 1686.7$ ) psia

(3120) volts

$(423) \pm(4.0)$ volts with an $(8.0+0.8)$ second time delay

Not Applicable

$\geq(45.61) \%$

$\leq(48.35)$ psi

$\leq(48.35) \mathrm{psi}$

$\geq(706.6)$ psia 
TABLE $3.3-5$

ENGINEERED SAFETY FEATURES RESPONSE TIMES

INITIATING SIGNAL AND FUNCTION

RESPONSE TIME IN SECONDS

1. Manual

a. SIAS

Safety Injection (ECCS)

Not Applicable

Containment Isolation

Not Applicable

Shield Building Filtration System

Not Applicable

Containment Purge Valve Isolation

Not Applicable

b. CSAS

Containment Spray

Not Applicable

c. CIAS

Containment Isolation

Not Applicable

Shield Building Filtration System

Not Applicable

Containment Purge Valve Isolation

Not Applicable

d. MSIS

Main Steam Isolation

Not Applicable

e. SBFAS

Shield Building Filtration System

Not Applicable

f. SRAS

Containment Sump Recirculation

Not Applicable

g. CPAS

Containment Purge Valve Isolation

Not Applicable

h. CCAS

Containment Cooling

Not Applicable

i. EFAS

Emergency Feedwater Pumps

Not Applicable 
TABLE 3.3-5 (Continued)

\section{ENGINEERED SAFETY FEATURES RESPONSE TIMES}

\section{INITIATING SIGNAL AND FUNCTION}

RESPONSE TIME IN SECONDS

2. Pressurizer Pressure-Low
a. Safety Injection (ECCS)
b. Containment Isolation
c. Shield Building Filtration System
d. Containment Cooling

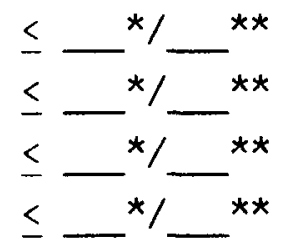

3. Containment Pressure-High
a. Safety Injection (ECCS)
b. Containment Isolation
c. Shield Building Filtration System
d. Containment Cooling

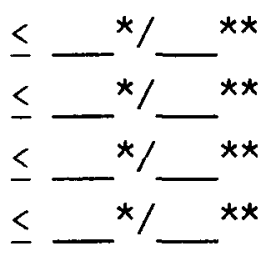

4. Containment Pressure--High-High
a. Containment Spray

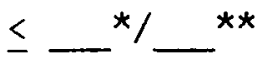

5. Containment Radiation-High
a. Containment Purge Valves Isolation
b. Shield Building Filtration System

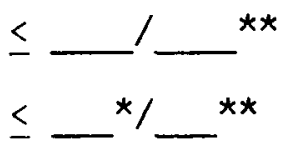

6. Steam Generator Pressure-Low
a. Main Steam Isolation
b. Emergency Feedwater

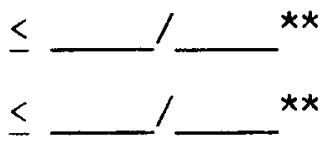

7. Refueling water Storage Tank-Low

a. Containment Sump Recirculation

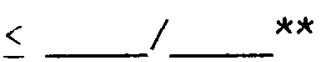

8. $4.16 \mathrm{Kv}$ Emergency Bus Undervoltage (Loss of Voltage)
a. Loss of Power
$\leq$

9. $4.16 \mathrm{kv}$ Emergency Bus Undervoltage (Degraded Voltage)

a. Loss of Power

$\leq$ 


\section{TABLE 3.3-5 (Continued)}

\section{ENGINEERED SAFETY FEATURES RESPONSE TIMES}

INITIATING SIGNAL AND FUNCTION

RESPONSE TIME IN SECONDS

10. Steam Generator Leve]-Low

a. Emergency Feedwater

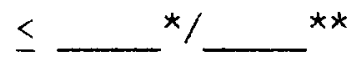

11. Steam Generator $\Delta P$-High-Coincident With Steam Generator Level Low

a. Emergency Feedwater

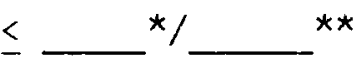

\section{TABLE NOTATION}

* Diesel generator starting and sequence loading delays included. Response time limit includes movement of valves and attainment of pump or blower discharge pressure.

**Diesel generator starting and sequence loading delays not included. Offsite power available. Response time limit includes movement of valves and attainment of pump or blower discharge pressure. 
TABLE 4.3-2

ENGINEERED SAFETY FEATURE ACTUATION SYSTEM INSTRUMENTAION SURVEILLANCE REQUIREMENTS

\section{FUNCTIONAL UNIT}

1. SAFETY INJECTION (SIAS)
a. Manual (Trip Buttons)
b. Containment Pressure - High
c. Pressurizer Pressure - Low
d. Automatic Actuation Logic

2. CONTAINMENT SPRAY (CSAS)
a. Manual (Trip Buttons)
b. Containment Pressure --

$$
\text { High - High }
$$

3. CONTAINMENT ISOLATION (CIAS)

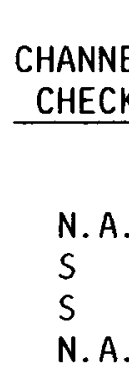

CHANNEL

FUNCTIONAL

TEST

CHANNEL

CALIBRATION
N.A.
$R$
$\mathrm{R}$
N.A.

$\begin{array}{lll}\text { N.A. } & \text { N.A. } & \text { R } \\ \text { S } & \text { R } & M(2) \\ \text { N.A. } & \text { N.A. } & M(1)\end{array}$
a. Manual CIAS (Trip Buttons)
b. Manual SIAS (Trip Buttons)
c. Containment Pressure - High
d. Pressurizer Pressure - Low
e. Automatic Actuation Logic

N.A.
N.A.
S
S
N. A.
N.A.
N.A.

4. MAIN STEAM LINE ISOLATION
a. Manual (Trip Buttons)
b. Steam Generator Pressure - Low
c. Automatic Actuation Logic
N.A.
N. A.

5. SHIELD BUILDING FILTRATION (SBFAS)

ह
ज.
c.
$\vec{\omega}$

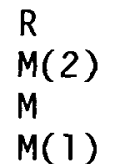

$M(1)$
a. Manual SBFAS (Trip Buttons)

N.A.

N.A.

$S$

$\mathrm{S}$

$\mathrm{S}$

f. Automatic Actuation Logic
S

$S$

Particulate Monitor

Area Monitor

N.A.
MODES IN WHICH SURVEILLANCE REQUIRED

N.A.

$1,2,3$

$1,2,3$

$1,2,3$

N.A.

$1,2,3$

$1,2,3$

N.A.

N. A.

$1,2,3$

$1,2,3$

$1,2,3$

N. A.

$1,2,3$

$1,2,3$

N. A.

N. A.

$1,2,3$

$1,2,3$

$1,2,3,4$

$1,2,3,4$

$1,2,3,4$

$1,2,3$ 
TABLE 4.3-2 (Continued)

\section{FUNCTIONAL UNIT}

6. CONTAINMENT SUMP
RECIRCULATION (SRAS)

a. Manual SRAS (Trip Buttons)

b. Refueling Water Storage

Tank - Low

c. Automatic Actuation Logic

7. CONTAINMENT PURGE VALVES ISOLATION

a. Manual (Purge Valve Control Switches)

b. Manual CIAS (Trip Buttons)

c. Manual SIAS (Trip Buttons)

d. Automatic CIAS Actuation

$$
\text { Logic }
$$

e. Containment Radiation - High

Gaseous Monitor

Particulate Monitor

Area Monitor

8. CONTAINMENT COOLING (CCAS)
a. Manual (Trip Buttons)
b. Containment Pressure - High
c. Pressurizer Pressure - Low
d. Automatic Actuation Logic

9. LOSS OF POWER

कृ
जा
$\overrightarrow{0}$
co

a. $\quad 4.16 \mathrm{kv}$ Emergency Bus Undervoltage (Loss of Voltage)

b. $\quad 4.16 \mathrm{kv}$ Emergency Bus Undervoltage (Degraded Voltage)

$\begin{array}{ll}\text { N.A. } & \text { N.A. } \\ \text { N.A. } & \text { N.A. } \\ \text { N.A. } & \text { N.A. } \\ \text { N.A. } & \text { N.A. } \\ \text { S } & \text { R } \\ \text { S } & \text { R } \\ \text { S } & \text { R }\end{array}$

\section{CHANNEL}

FUNCTIONAL

TEST

CALIBRATION

N.A.

R

$S$

N.A.

N.A.

$M(1)$

$1,2,3$

$1,2,3$
MODES IN WHICH

SURVE ILLANCE

REQUIRED

$\begin{array}{llll}\text { N. A. } & \text { N.A. } & R & \text { N.A. } \\ \text { S } & R & M(2) & 1,2,3 \\ \text { S } & R & M & 1,2,3 \\ \text { N.A. } & \text { N.A. } & M(1) & 1,2,3\end{array}$

N. A.

N.A.

N.A.

$1,2,3$

$1,2,3,4$

$1,2,3,4$

$1,2,3,4$

$M$

$1,2,3$

R

R

$1,2,3$

S

R

$\mathrm{R}$

$1,2,3$ 
TABLE 4.3.-2 (Continued)

\section{FUNCTIONAL UNIT}

10. EMERGENCY FEEDWATER (EFAS)
a. Manual (Trip Buttons)
b. SG Level and Pressure (A/B)-Low

$$
\text { and } \Delta P(A / B) \text { - High }
$$
c. SG Level (A/B) - Low and No Pressure - Low Trip (A/B)
d. Automatic Actuation Logic

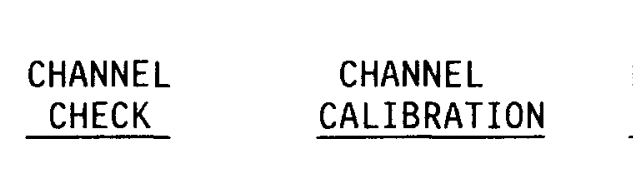

CHANNEL

FUNCTIONAL

TEST

MODES IN WHICH
SURVEILLANCE

REQUIRED

$\begin{array}{llll}\text { N.A. } & \text { N.A. } & \text { R } & \text { N.A. } \\ \text { S } & \text { R } & \text { M } & 1,2,3 \\ \text { S } & \text { R } & M & 1,2,3 \\ \text { N.A. } & \text { N.A. } & M(1) & 1,2,3\end{array}$

(1) Each train or logic channel shall be tested at least every other 31 days.

(2) The CHANNEL FUNCTIONAL TEST shall include exercising the transmitter by applying either a vacuum or pressure to the appropriate side of the transmitter. 
INSTRUMENTATION

3/4.3.3 MONITORING INSTRUMENTATION

RADIATION MONITORING INSTRUMENTATION

LIMITING CONDITION FOR OPERATION

3.3.3.1 The radiation monitoring instrumentation channels shown in Table 3.3-6 shall be OPERABLE with their alarm/trip setpoints within the specified limits.

APPLICABILITY: As shown in Table 3.3-6.

ACTION:

a. With a radiation monitoring channel alarm/trip setpoint exceeding the value shown in Table 3.3-6, adjust the setpoint to within the limit within 4 hours or declare the channel inoperable.

b. With one or more radiation monitoring channels inoperable, take the ACTION shown in Table 3.3-6.

c. The provisions of Specifications 3.0 .3 and 3.0.4 are not applicable.

4.3.3.1 Each radiation monitoring instrumentation channel shall be demonstrated OPERABLE by the performance of the CHANNEL CHECK, CHANNEL CALIBRATION and CHANNEL FUNCTIONAL TEST operations for the MODES and at the frequencies shown in Table 4.3-3. 
TABLE $3 \cdot 3-6$

莦

\section{RADIATION MONITORING INSTRUMENTATION}

\section{INSTRUMENT}

MINIMUM

CHANNELS

OPERABLE

\section{APPLICABLE}

ALARM/TRIP

MEASUREMENT

MODES

RANGE

ACTION

1. AREA MONITORS

a. Fuel Storage Pool Area

i. Criticality Monitor

ii. Ventilation System

Isolation

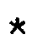

**

b. Containment - Purge \&

Exhaust Isolation

\section{6}

c. Control Room Isolation

ALL MODES

SETPOINT

$\downarrow$ 2. PROCESS MONITORS

$\underset{\infty}{\sim}$

a. Fuel Storage Pool Area

Ventilation System Isolation

i. Gaseous Activity

ii. Particulate Activity (1)

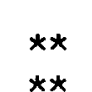

(< $2 x$ background)

( $\leq 2 \times$ background)

$\left(1-10_{5}^{5}\right) \mathrm{cpm}$

$\left(10^{-1}-10^{4}\right) \mathrm{mR} / \mathrm{hr}$

11

(<2x background) $\quad\left(1-10^{5}\right) \mathrm{cpm}$

$(\leq 2 \times$ background $) \quad\left(1-10^{5}\right) \mathrm{cpm}$

b. Containment

i. Gaseous Activity

a) Purge \& Exhaust

$$
\text { Isolation }
$$

b) RCS Leakage Detection(1)

$$
1,2,3 \& 4
$$

( $\leq 2 \times$ background)

Not Applicable

$\left(1-10_{5}^{5}\right) \mathrm{cpm}$

$\left(1-10^{5}\right) \mathrm{cpm}$

14

ii. Particulate Activity

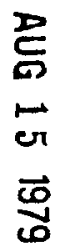

a) Purge \& Exhaust

$$
\text { Isolation }
$$

b) RCS Leakage Detection (1)

$1,2,3 \& 4$

( $\leq 2 x$ background)

Not Applicable

$\left(1-10^{5}\right) \mathrm{cpm}$

12

* With fuel in the storage pool or building

** With irradiated fuel in the storage pool 


\section{TABLE 3.3-6 (Continued)}

TABLE NOTATION

ACTION 11 - With the number of channels OPERABLE less than required by the Minimum Channels OPERABLE requirement, perform area surveys of the monitored area with portable monitoring instrumentation at least once per 24 hours.

ACTION 12 - With the number of channels OPERABLE less than required by the Minimum Channels OPERABLE requirement, comply with the ACTION requirements of Specification (3.4.6.1).

ACTION 13 - With the number of channels OPERABLE less than required by the Minimum Channels OPERABLE requirement, comply with the ACTION requirements of Specification (3.9.12).

ACTION 14 - With the number of channels OPERABLE less than required by the Minimum Channels OPERABLE requirement, comply with the ACTION requirements of Specification (3.9.9).

ACTION 15 - With the number of channels OPERABLE less than required by the Minimum Channels OPERABLE requirement, within 1 hour initiate and maintain operation of the control room emergency ventilation system in the recirculation mode of operation. 
TABLE 4.3-3

\section{RADIATION MONITORING INSTRUMENTATION SURVEILLANCE REQUIREMENTS}

\section{INSTRUMENT}

CHANNEL

CHANNEL

CHANNEL

FUNCTIONAL

MODES IN WHICH

CALIBRATION

TEST

SURVEILLANCE

1. AREA MONITORS

a. Fuel Storage Pool Area

i. Criticality Monitor

ii. Ventilation System Isolation

$\mathrm{S}$

S

b. Containment - Purge \&

Exhaust Isolation

c. Control Room Isolation

2. PROCESS MONITORS

a. Fuel Storage Pool Area - Ven-

tilation System Isolation

i. Gaseous Activity

ii. Particulate Activity

b. Containment

i. Gaseous Activity

a) Purge \& Exhaust Isolation

b) RCS Leakage Detection

ii. Particulate Activity

a) Purge \& Exhaust Isolation

b) RCS Leakage Detection
$\mathrm{S}$

S
$R$
$R$

$R$

$R$

$\mathrm{R}$
M

M

M

M

$M$

$\star \star \star *$

$* *$

6

$M$

$1,2,3, \& 4$

M

6

$1,2,3, \& 4$
* With fuel in the storage pool or building

** With irradiated fuel in the storage pool 
INSTRUMENTATION

INCORE DETECTORS

LIMITING CONDITION FOR OPERATION

3.3.3.2 The incore detection system shall be OPERABLE with:

a. At least $75 \%$ of all incore detector locations, and

b. A minimum of two quadrant symmetric incore detector locations per core quadrant.

An OPERABLE incore detector location shall consist of a fuel assembly containing a fixed detector string with a minimum of four OPERABLE rhodium detectors or an OPERABLE movable incore detector capable of mapping the location.

APPLICABILITY: When the incore detection system is used for monitoring:
a. AZIMUTHAL POWER TILT,
b. Radial Peaking Factors,
c. Local Power Density,
d. DNB Margin.

ACTION:

With the incore detection system inoperabie, do not use the system for the above applicable monitoring or calibration functions. The provisions of Specifications 3.0 .3 and 3.0 .4 are not applicable.

\section{SURVEILLANCE REQUIREMENTS}

4.3.3.2 The incore detection system shall be demonstrated OPERABLE:

a. By performance of a CHANNEL CHECK within 24 hours prior to its use and at least once per 7 days thereafter when required for monitoring the AZIMUTHAL POWER TILT, radial peaking factors, local power density or DNB margin:

b. At least once per 18 months by performance of a CHANNEL CALIBRATION operation which exempts the neutron detectors but includes all electronic components. The neutron detectors shall be calibrated prior to installation in the reactor core. 
INSTRUMENTATION

SEISMIC INSTRUMENTATION*

3.3.3.3 The seismic monitoring instrumentation shown in Table 3.3-7 shall be OPERABLE.

APPLICABILITY: At al1 times.

ACTION:

a. With one or more seismic monitoring instruments inoperable for more than 30 days, prepare and submit a Special Report to the Commission pursuant to Specification 6.9.2 within the next 10 days outlining the cause of the malfunction and the plans for restoring the instrument(s) to OPERABLE status.

b. The provisions of Specifications 3.0 .3 and 3.0.4 are not applicable.

\section{SURVEILLANCE REQUIREMENTS}

4.3.3.3.1 Each of the above seismic monitoring instruments shall be demonstrated OPERABLE by the performance of the CHANNEL CHECK, CHANNEL CALIBRATION and CHANNEL FUNCTIONAL TEST operations at the frequencies shown in Table 4. 3-4.

4.3.3.3.2 Each of the above seismic monitoring instruments actuated during a seismic event shall be restored to OPERABLE status within 24 hours and a CHANNEL CALIBRATION performed within 5 days following the seismic event. Data shall be retrieved from actuated instruments and analyzed to determine the magnitude of the vibratory ground motion. A Special Report shall be prepared and submitted to the Commission pursuant to Specification 6.9.2 within 10 days describing the magnitude, frequency spectrum and resultant effect upon facility features important to safety.

*This specification not required for additional units at a common site provided at least one unit has seismic instrumentation and corresponding technical specifications meeting the recommendations of Regulatory Guide 1.12, April 1974. 
TABLE $3.3-7$

SEISMIC MONITORING INSTRUMENTATION

INSTRUMENTS AND SENSOR LOCATIONS

\begin{tabular}{cc} 
MEASUREMENT & MINIMUM \\
RANGE & INSTRUMENT \\
\cline { 1 - 1 } & OPERABLE \\
\hline
\end{tabular}

1. Triaxial Time-History Accelerographs

a.

b.

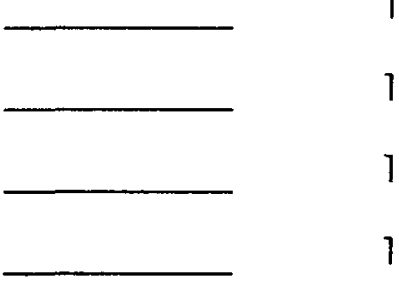

2. Triaxial Peak Accelerographs

a.

b.

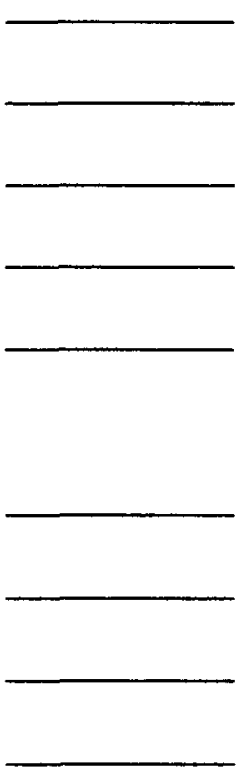

1

1

c.

d.

e.

3. Triaxial Seismic Switches

a.

b.

c.

d.

4. Triaxial Response-Spectrum Recorders

a.

b.

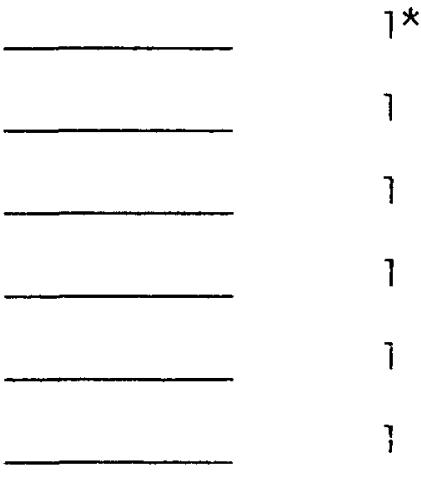

* With reactor control room indication CE-STS 


\section{TABLE $4.3-4$}

SEISMIC MONITORING INSTRUMENTATION SURVEILLANCE REQUIREMENTS

INSTRUMENTS AND SENSOR LOCATIONS

1. Triaxial Time-History Accelerographs

a.

b.

c.

d.

2. Triaxial Peak Accelerographs

a.

b.

c.

d.

e.

3. Triaxial Seismic Switches

a.

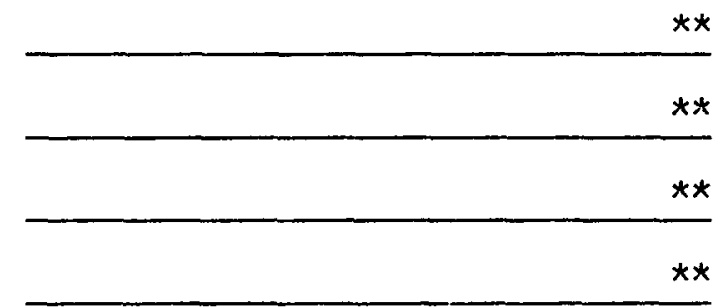

4. Triaxial Response-Spectrum Recorders

a.

**

b.

c.

d.

e.

$f$.

* Except seismic trigger

** With reactor control room indication CE-STS
CHANNEL CHANNEL FUNCTIONAL

CHECK CALIBRATION TEST

$\begin{array}{lll}M^{*} & R & S A \\ M^{*} & R & S A \\ M^{*} & R & S A \\ M^{*} & R & S A\end{array}$

NA $\quad$ NA

NA $\quad$ NA

$\begin{array}{lll}N A & R & N A\end{array}$

NA $\quad$ NA

NA $\quad R \quad N A$

$M \quad R \quad S A$

$M \quad$ R $~ S A$

$\begin{array}{lll}M & R & S A\end{array}$

$\begin{array}{lll}M & R & S A\end{array}$

$\begin{array}{lll}M & \mathrm{R}\end{array}$

$\begin{array}{lll}N A & R & S A\end{array}$

$\begin{array}{lll}N A & R & S A\end{array}$

NA $\quad R \quad S A$

NA $R$ SA

$\begin{array}{lll}\text { NA } & \mathrm{R}\end{array}$

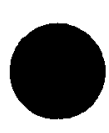


INSTRUMENTATION

METEOROLOGICAL INSTRUMENTATION*

LIMITING CONDITION FOR OPERATION

3.3.3.4 The meteorological monitoring instrumentation channels shown in Table 3.3-8 shall be OPERABLE.

APPLICABILITY: At al1 times.

ACTION:

a. With one or more required meteorological monitoring channels inoperable for more than 7 days, prepare and submit a Special Report to the Commission pursuant to Specification 6.9 .2 within the next 10 days outlining the cause of the malfunction and the plans for restoring the channel(s) to OPERABLE status.

b. The provisions of Specifications 3.0.3 and 3.0.4 are not applicable.

SURVEILLANCE REQUIREMENTS

4.3.3.4 Each of the above meteorological monitoring instrumentation channels shall be demonstrated OPERABLE by the performance of the CHANNEL CHECK and CHANNEL CALIBRATION operations at the frequencies shown in Table 4.3-5.

*This specification not required for additional units at a common site provided at least one unit has meteorological instrumentation and corresponding technical specifications and that the same meteorological data is applicable to the additional units. 
TABLE $3.3-8$

METEOROLOGICAL MONITORING INSTRUMENTATION

INSTRUMENT

1. WIND SPEED

a.

b.

2. WIND DIRECTION

a.

b.

3. AIR TEMPERATURE - DELTA T

a.

b.

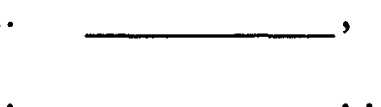

LOCATION

Nominal Elev.

Nominal Elev.

Nominal Elev.

MINIMUM

OPERABLE

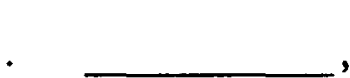

Nominal Elev.

Nominal Elev.

Nominal Elev.
1

1

1

1

1

1 


\section{TABLE $4.3-5$}

METEOROLOGICAL MONITORING INSTRUMENTATION SURVEILLANCE REQUIREMENTS

\section{INSTRUMENT}

CHANNEL

CHANNEL

1. WIND SPEED
a. Nominal Elev.
D
SA
b. Nominal Elev.
D
SA

2. WIND DIRECTION
a. Nominal Elev.
D
SA
b. Nominal Elev.
D
SA

3. AIR TEMPERATURE - DELTA T
a. Nominal Elev.
D
SA
b. Nominal Elev.
D
SA 
INSTRUMENTATION

REMOTE SHUTDOWN INSTRUMENTATION

LIMITING CONDITION FOR OPERATION

3.3.3.5 The remote shutdown monitoring instrumentation channels shown in Table 3.3-9 shall be OPERABLE with readouts displayed external to the control room.

APPLICABILITY: MODES 1,2 and 3.

ACTION:

a. With the number of OPERABLE remote shutdown monitoring channels less than required by Table 3.3-9, either restore the inoperable channel to OPERABLE status within 30 days, or be in HOT SHUTDOWN within the next 12 hours.

b. The provisions of Specification 3.0.4 are not applicable.

4.3.3.5 Each remote shutdown monitoring instrumentation channel shall be demonstrated OPERABLE by performance of the CHANNEL CHECK and CHANNEL CALIBRATION operations at the frequencies shown in Table 4.3-6. 
TABLE $3.3-9$

INSTRUMENT

1. Power Range Neutron Flux

2. Intermediate Range Neutron Flux

3. Source Range Neutron Flux

4. Reactor Trip Breaker Indication

5. Reactor Coolant Temperature Average

6. Reactor Coolant Flow Rate

7. Pressurizer Pressure

8. Pressurizer Level

9. Steam Generator Pressure

10. Steam Generator Level

11. Control Rod Position Limit Switches

12. Shutdown Cooling Flow Rate

13. Shutdown Cooling Temperature

or 14. Auxiliary Feedwater Flow Rate
READOUT

LOCATION

CHANNELS

RANGE

OPEN-CLOSE
MINIMUM

CHANNELS

OPERABLE

1

1

1/trip breaker

1

1

1/steam generator

1/steam generator

1 insertion limit switch/rod

1

1

क्ర 
TABLE 4.3-6

REMOTE SHUTDOWN MONITORING INSTRUMENTATION SURVEILLANCE REQUIREMENTS

$\omega$
$\omega$
1
$t$
0

\section{INSTRUMENT}

1. Power Range Neutron Flux

2. Intermediate Range Neutron Flux

3. Source Range Neutron Flux

4. Reactor Trip Breaker Indication

5. Reactor Coolant TemperatureAverage

7. Pressurizer Pressure

8. Pressurizer Level

9. Steam Generator Level

10. Steam Generator Pressure

11. Control Rod Position Limit Switches

12. Shutdown Cooling Flow Rate

13. Shutdown Cooling Temperature

完 in

๘̋

14. Auxiliary Feedwater Flow Rate
6. Reactor Coolant Flow Rate

CHANNEL CHANNEL

CHECK CALIBRATION

M

\section{Q}

N.A.

N.A.

N.A.
$M$

$M$

$M$

M
R

R

R

R

R

R

R

R

R

$R$

$\mathrm{R}$

R

R 
INSTRLIMFNTATION

POST-ACCIIENT IIISTRUMENTATION

LIMITIMG COMOITIOM FOP APEPATION

3.3.3.6 The post-accident monitoring instrumentation channels shown in Table 3.3-10 shall be OPERABLE.

APPLICARILITY: MONES 1,2 and 3.

ACTION:

a. With the number of OPERABLE post-accident monitoring channels less than required by Tahle 3.3-10, either restore the inoperable channel to OPERABLE status within 30 days, or be in HOT SHUTOCWN within the next 12 hours.

b. The provisions of Specification 3.n.4 are not anplicahle.

4.3.3.6 Each post-accident monitoring instrumentation channel shall he demonstrated MPEPABLE hy performance of the CHANMEL CHECK and CHANNFL CALIRPATINM operations at the frequencies shown in Table 4.3-7. 
TABLE $3.3-10$

\section{POST-ACCIDENT MONITORING INSTRUMENTATION}

INSTRUMENT (I I lustrational Only)

MINIMUM

CHANNELS

1. Containment Pressure

2

2. Reactor Coolant Outlet Temperature - $\mathrm{T}_{\text {Hot }}$ (Wide Range)

2

3. Reactor Coolant Inlet Temperature - $T_{\text {Cold }}$ (Wide Range)

2

4. Reactor Coolant Pressure - Wide Range

2

5. Pressurizer Water Leve

2

$\stackrel{\omega}{\omega}$

6. Steam Line Pressure

7. Steam Generator Water Level - Narrow Range

$2 /$ steam generator

8. Steam Generator Water Leve1 - Wide Range

1/steam generator

9. Refueling Water Storage Tank Water Leve 1

1/steam generator

10. Boric Acid Storage Tank Solution Level 
TABLE $4.3-7$

POST-ACCIDENT MONITORING INSTRUMENTATION SURVEILLANCE REQUIREMENTS

\section{INSTRUMENT (I llustrational Only)}

1. Containment Pressure

2. Reactor Coolant Outlet Temperature - $\mathrm{T}_{\text {Hot }}$ (Wide Range)

3. Reactor Coolant Inlet Temperature $-T_{\text {Cold }}$ (Wide Range)

4. Reactor Coolant Pressure - Wide Range

5. Pressurizer Water Level

$\omega$
$\omega$
$\omega$
$\omega$
$\omega$

6. Steam Line Pressure

7. Steam Generator Water Level - Narrow Range

8. Steam Generator Water Level - Wide Range

9. Refueling Water Storage Tank Water Level

10. Boric Acid Storage Tank Solution Level
CHANNEL
CHECK

$$
\text { M }
$$

M

M

M

M

M

M

M

M

M
CHANNEL CALIBRATION

R

R

R

R

R

R

R

R

R

R 
INSTRUMENTATION

CHLORINE DETECTION SYSTEMS (OPTIONAL)

3.3.3.7 Two independent chlorine detection systems, with their alarm/trip setpoints adjusted to actuate at a chlorine concentration of less than or equal to $5 \mathrm{ppm}$, shall be OPERABLE.

APPLICABILITY: MODES $1,2,3$ and 4

ACTION:

a. With one chlorine detection system inoperable, restore the inoperable detection system to OPERABLE status within 7 days or within the next 6 hours initiate and maintain operation of the control room emergency ventilation system in the recirculation mode of operation.

b. With no chlorine detection system OPERABLE, within 1 hour initiate and maintain operation of the control room emergency ventilation system in the recirculation mode of operation.

c. The provisions of Specification 3.0.4 are not applicable.

4.3.3.7 Each chlorine detection system shall be demonstrated OPERABLE by performance of a CHANNEL CHECK at least once per 12 hours, a CHANNEL FUNCTIONAL TEST at least once per 31 days and a CHANNEL CALIBRATION AT least once per 18 months. 
INSTRUMMENTATINN!

FIRE DETFCTION INSTRUMENTATION

LIMITINC. CONDITION FOR OPERATION

3.3.3.8 As a minimum, the fire detection instrumentation for each fire detection zone shown in Table $3.3-11$ shall be CPEPARLF.

APPLICARILITY: Whenever equipment in that fire detection zone is required to be OPERARLE.

\section{ACTION:}

With one or more of the fire detection instrument(s) shown in Table 3.3-11 inoperable:

a. Hithin 1 hour estahlish a fire watch natrol to inspect the zone(s) with the inoperable instrument(s) at least once per hour, unless the instrument $(s)$ is located inside the containment, then inspect the containment at least once per $\&$ hours or (monitor the containment air temperature at least once per hour at the locations listed in Specification 4.6.1.6).

h. Pestore the inonerable instrument(s) to CPERARLF status within 14 days or, in lieu of any other report required by Specification 6.9.1, prepare and suhmit a Special Peport to the Commission pursuant to Specification 6.9 .2 within the next 30 days outlining the action taken, the cause of the inoperahility and the plans and schedule for restoring the instrument(s) to OPEPARLF status.

c. The provisions of Specifications 3.0 .3 and 3.0 .4 are not applicahle.

\section{SURVEILLANCE REOIIIPEMENTS}

4.3.3.8.1 Each of the above required fire detection instruments which are accessible during plant operation shall he demonstrated OPERARLE at least once per 6 months hy performance of a CHANNEL FUNCTIONAL TEST. Fire detectors which are not accessible during plant operation shall be demonatrated CPEPAPLE by the performance of a CHANNEL FUNCTIONAL TEST during each COLN SHUTDOWN exceeding 24 hours unless performed in the previous 6 months.

4.3.3.8.2 The NFPA Standard $72 n$ supervised circuits supervision associated with the detector alarms of each of the above required fire detection instruments shall he demonstrated OPFRABLF at least once per 6 months.

4.3.3.8.3 The non-supervised circuits associated with detector alarms hetween the instruments and the control room shall be demonstrated CPERARLE at least once per 31 days. 
TABLE 3.3-11

FIRE DETECTION INSTRLIMENTS

INSTRUMENT LOCATION (IIlus trative)**

MINIMUM INSTRUMENTS OPERABLE*

HEAT FLAME SMOKE

1. Containment

Zone 1 Elevation

Zone 2 Elevation

2. Control Room

3. Cable Spreading

Zone 1 Elevation

Zone 2 Elevation

4. Computer Poom

5. Switchgear Room

6. Remote Shutdown Panels

7. Station Battery Rooms

Zone 1 Elevation

Zone 2 Elevation

8. Turbine

Zone 1 Elevation

Zone 2 Elevation

9. Diesel Generator

Zone 1 Elevation

Zone 2 Elevation

10. Diesel Fuel Storage

11. Safety Related Pumps

Zone 1 Elevation

Zone 2 Elevation

12. Fuel Storage

Zone 1 Elevation

Zone 2 Elevation

*The fire detection instruments located within the Containment are not required to be OPERABLE during the performance of Type A Containment Leakage Rate Tests.

** List all detectors in areas required to insure the OPERABILITY of safety related equipment and indicate instruments which automatically actuate fire suppression systems. 
INSTRUMENTATION

3/4.3.4 TURBINE OVERSPEED PROTECTION

LIMITING CONDITION FOR OPERATION

3.3.4 At least one turbine overspeed protection system shall be OPERABLE. APPLICABILITY: MODES 1,2 and 3.

ACTION:

a. With one stop valve or one control valve per high pressure turbine steam lead inoperable or with one reheat stop valve or one reheat intercept valve per low pressure turbine steam lead inoperable, operation may continue for up to 72 hours provided the inoperable valve(s) is restored to OPERABLE status or at least one valve in the affected steam lead is closed; otherwise, isolate the turbine from the steam supply within the next 6 hours.

b. With the above required turbine overspeed protection system otherwise inoperable, within 6 hours either restore the system to OPERABLE status or isolate the turbine from the steam supply.

SURVEILLANCE REQUIREMENTS

4.3.4.1 The provisions of Specification 4.0.4 are not applicable.

4.3.4.2 The above required turbine overspeed protection system shall be demonstrated OPERABLE:

a. At least once per 7 days by cycling each of the following valves through at least one complete cycle from the running position.

1. (Four) high pressure turbine stop valves.

2. (Four) high pressure turbine control valves.

3. (Four) low pressure turbine reheat stop valves.

4. (Four) low pressure turbine reheat intercept valves.

b. At least once per 31 days by direct observation of the movement of each of the above valves through one complete cycle from the running position. 
c. At least once per 18 months by performance of a CHANNEL CALIBRATION on the turbine overspeed protection systems.

d. At least once per 40 months by disassembling at least one of each of the above valves and performing a visual and surface inspection of valve seats, disks and stems and verifying no unacceptable flaws or corrosion. 
$3 / 4.4$ REACTOR COOLANT SYSTEM

3/4.4.1 REACTOR COOLANT LOOPS

LIMITING CONDITION FOR OPERATION

3.4.1 Both reactor coolant loops and both reactor coolant pumps in each loop shall be in operation.

APPLICABILITY: As noted below, but excluding MODE $6 . *$

ACTION:

MODES 1 and 2:

a. With one reactor coolant pump not in operation, STARTUP and/or continued POWER OPERATION may proceed provided THERMAL POWER is restricted to less than or equal to ( )\% of RATED THERMAL POWER and the setpoint for the Linear Power Level - High trip has been reduced to the value specified in Specification 2.2.1 for operation with three reactor coolant pumps operating.

b. With two reactor coolant pumps in opposite loops not in operation, STARTUP and/or continued POWER OPERATION may proceed provided THERMAL POWER is restricted to less than or equal to ( )\% of RATED THERMAL POWER and the setpoint for the Linear Power Level - High trip has been reduced to the value specified in Specification 2.2.1 for operation with two reactor coolant pumps operating in opposite loops.

c. With two reactor coolant pumps in the same loop not in operation, STARTUP and/or continued POWER OPERATION may proceed provided the water level in both steam generators is maintained above the Steam Generator Water Level-Low trip setpoint, the THERMAL POWER is restricted to less than or equal to ( )\% of RATED THERMAL POWER, and the setpoint for the Linear Power Leve1 - High trip has been reduced to the value specified in Specification 2.2.1 for operation with two reactor coolant pumps operating in the same loop.

ॠSee Special Test Exception 3.10.3 


\section{REACTOR COOLANT SYSTEM}

ACTION: (Continued)

$\operatorname{MODES} 3,4^{* *}$ and $5:$

Operation may proceed provided at least one reactor coolant loop is in operation with an associated reactor coolant pump or shutdown cooling pump.* The provisions of Specifications 3.0 .3 and 3.0 .4 are not applicable.

* All reactor coolant pumps and shutdown cooling pumps may be de-energized for up to 1 hour, provided no operations are permitted which could cause dilution of the reactor coolant system boron concentration.

**

A reactor coolant pump shall not be started with one or more of the RCS cold leg temperatures less than or equal to $(275)^{\circ} \mathrm{F}$ unless 1 ) the pressurizer water volume is less than (900) cubic feet or 2) the secondary water temperature of each steam generator is less than $(46)^{\circ} \mathrm{F}$ above each of the RCS cold leg temperatures.

\section{SURVEILLANCE REQUIREMENTS}

4.4.1 The Reactor Protective Instrumentation channels specified in the applicable ACTION statement above shall be verified to have had their trip setpoints changed to the values specified in Specification 2.2.1 for the applicable number of reactor coolant pumps operating either:

a. Within 4 hours after switching to a different pump combination if switch is made while operating, or

b. Prior to reactor criticality if switch is made while shutdown. 


\section{REACTOR COOLANT SYSTEM}

\section{$3 / 4.4 .2$ SAFETY VALVES - SHUTDOWN}

3.4.2 A minimum of one pressurizer code safety valve shall be OPERABLE with a lift setting of 2500 PSIA $\pm 1 \%$.*

APPLICABILITY: MODES 4 and 5.

\section{ACTION:}

With no pressurizer code safety valve OPERABLE, immediately suspend all operations involving positive reactivity changes and place an OPERABLE shutdown cooling loop into operation.

4.4.2 No additional Surveillance Requirements other than those required by Specification 4.0.5.

The lift setting pressure shall correspond to ambient conditions of the valve at nominal operating temperature and pressure. 
REACTOR COOLANT SYSTEM

3/4.4.3 SAFETY VALVES - OPERATING

LIMITING CONDITION FOR OPERATION

3.4.3 All pressurizer code safety valves shall be OPERABLE with a lift setting of 2500 PSIA $\pm 1 \%$.*

APPLICABILITY: MODES 1,2 and 3.

ACTION:

With one pressurizer code safety valve inoperable, either restore the inoperable valve to OPERABLE status within 15 minutes or be in at least HOT STANDBY

within 6 hours and in HOT SHUTDOWN within the following 6 hours.

4.4.3 No additional Surveillance Requirements other than those required by Specification 4.0.5.

*The lift setting pressure shall correspond to ambient conditions of the valve at nominal operating temperature and pressure. 


\section{REACTOR COOLANT SYSTEM}

3/4.4.4 PRESSURIZER

\section{LIMITING CONDITION FOR OPERATION}

3.4.4 The pressurizer shall be OPERABLE with a water volume of less than or equal to cubic feet.

APPLICABILITY: MODES 1,2 and 3.

ACTION:

With the pressurizer inoperable, be in at least HOT STANDBY with the reactor trip breakers open within 6 hours and in HOT SHUTDOWN within the following 6 hours.

4.4.4 The pressurizer water volume shall be determined to be within its limit at least once per 12 hours. 
REACTOR COOLANT SYSTEM

3/4.4.5 STEAM GENERATORS

LIMITING CONDITION FOR OPERATION

3.4.5 Each steam generator shall be OPERABLE.

APPLICABILITY: MODES $1,2,3$ and 4.

ACTION:

With one or more steam generators inoperable, restore the inoperable generator(s) to OPERABLE status prior to increasing $\mathrm{T}_{\text {avg }}$ above $200^{\circ} \mathrm{F}$.

SURVEILLANCE REQUIREMENTS

4.4.5.0 Each steam generator shall be demonstrated OPERABLE by performance of the following augmented inservice inspection program and the requirements of Specification 4.0 .5 .

4.4.5.1 Steam Generator Sample Selection and Inspection - Each steam generator shall be determined OPERABLE during shutdown by selecting and inspecting at least the minimum number of steam generators specified in Table 4.4-1.

4.4.5.2 Steam Generator Tube Sample Selection and Inspection - The steam generator tube minimum sample size, inspection result classification, and the corresponding action required shall be as specified in Table 4.4-2. The inservice inspection of steam generator tubes shall be performed at the frequencies specified in Specification 4.4.5.3 and the inspected tubes shall be verified acceptable per the acceptance criteria of Specification 4.4.5.4. The tubes selected for each inservice inspection shall include at least $3 \%$ of the total number of tubes in all steam generators; the tubes selected for these inspections shall be selected on a random basis except:

a. Where experience in similar plants with similar water chemistry indicates critical areas to be inspected, then at least $50 \%$ of the tubes inspected shall be from these critical areas.

b. The first sample of tubes selected for each inservice inspection (subsequent to the preservice inspection) of each steam generator shall include: 
1. All nonplugged tubes that previously had detectable wall penetrations (greater than 20\%).

2. Tubes in those areas where experience has indicated potential problems.

3. A tube inspection (pursuant to Specification 4.4.5.4.a.8) shall be performed on each selected tube. If any selected tube does not permit the passage of the eddy current probe for a tube inspection, this shall be recorded and an adjacent tube shall be selected and subjected to a tube inspection.

c. The tubes selected as the second and third samples (if required by Table 4.4-2) during each inservice inspection may be subjected to a partial tube inspection provided:

1. The tubes selected for these samples include the tubes from those areas of the tube sheet array where tubes with imperfections were previously found.

2. The inspections include those portions of the tubes where imperfections were previously found.

The results of each sample inspection shall be classified into one of the following three categories:

Category
$c-1$$\quad \begin{aligned} & \text { Inspection Results } \\ & \text { Less than } 5 \% \text { of the total tubes inspected are } \\ & \text { degraded tubes and none of the inspected tubes } \\ & \text { are defective. }\end{aligned}$


REACTOR COOLANT SYSTEMS

SURVEILLANCE REQUIREMENTS (Continued)

4.4.5.3 Inspection Frequencies - The above required inservice inspections of steam generator tubes shall be performed at the following frequencies:

a. The first inservice inspection shall be performed after 6 Effective

Full Power Months but within 24 calender months of initial criticality. Subsequent inservice inspections shall be performed at intervals of not less than 12 nor more than 24 calendar months after the previous inspection. If two consecutive inspections following service under AVT conditions, not including the preservice inspection, result in all inspection results falling into the $\mathrm{C}-1$ category or if two consecutive inspections demonstrate that previously observed degradation has not continued and no additional degradation has occurred, the inspection interval may be extended to a maximum of once per 40 months.

b. If the results of the inservice inspection of a steam generator conducted in accordance with Table 4.4-2 at 40 month intervals fall into Category $\mathrm{C}-3$, the inspection frequency shall be increased to at least once per 20 months. The increase in inspection frequency shall apply until the subsequent inspections satisfy the criteria of Specification 4.4.5.3.a; the interval may then be extended to a maximum of once per 40 months.

c. Additional, unscheduled inservice inspections shall be performed on each steam generator in accordance with the first sample inspection specified in Table 4.4-2 during the shutdown subsequent to any of the following conditions:

1. Primary-to-secondary tubes leaks (not including leaks originating from tube-to-tube sheet welds) in excess of the limits of Specification 3.4.6.2.

2. A seismic occurrence greater than the Operating Basis Earthquake.

3. A loss-of-coolant accident requiring actuation of the engineered safeguards.

4. A main steam line or feedwater line break. 
REACTOR COOLANT SYSTEM

SURVEILLANCE REQUIREMENTS (Continued)

\subsubsection{Acceptance Criteria}

a. As used in this Specification

1. Imperfection means an exception to the dimensions, finish or contour of a tube from that required by fabrication drawings or specifications. Eddy-current testing indications below $20 \%$ of the nominal tube wall thickness, if detectable, may be considered as imperfections.

2. Degradation means a service-induced cracking, wastage, wear or general corrosion occurring on either inside or outside of a tube.

3. Degraded Tube means a tube containing imperfections greater than or equal to $20 \%$ of the nominal wall thickness caused by degradation.

4. \% Degradation means the percentage of the tube wall thickness affected or removed by degradation.

5. Defect means an imperfection of such severity that it exceeds the plugging limit. A tube containing a defect is defective.

6. Plugging Limit means the imperfection depth at or beyond which the tube shal1 be removed from service because it may become unserviceable prior to the next inspection and is equal to $(40) \% *$ of the nominal tube wall thickness.

7. Unserviceable describes the condition of a tube if it leaks or contains a defect large enough to affect its structural integrity in the event of an Operating Basis Earthquake, a loss-of-coolant accident, or a steam line or feedwater line break as specified in 4.4.5.3.c, above.

8. Tube Inspection means an inspection of the steam generator tube from the point of entry (hot leg side) completely around the $\mathrm{U}$-bend to the top support of the cold leg.

9. Preservice Inspection means an inspection of the full length of each tube in each steam generator performed by eddy current techniques prior to service to establish a baseline

*Value to be determined in accordance with the recommendations of Regulatory Guide 1.121, August 1976. 
condition of the tubing. This inspection shall be performed after the field hydrostatic test and prior to initial POWER OPERATION using the equipment and techniques expected to be used during subsequent inservice inspections.

b. The steam generator shall be determined OPERABLE after completing the corresponding actions (plug all tubes exceeding the plugging limit and all tubes containing through-wall cracks) required by Table 4.4-2.

\subsubsection{Reports}

a. Following each inservice inspection of steam generator tubes, the number of tubes plugged in each steam generator shall be reported to the Commission within 15 days.

b. The complete results of the steam generator tube inservice inspection shall be submitted to the Commission in a Special Report pursuant to Specification 6.9.2 within 12 months following completion of the inspection. This Special Report shall include:

1. Number and extent of tubes inspected.

2. Location and percent of wall-thickness penetration for each indication of an imperfection.

3. Identification of tubes plugged.

c. Results of steam generator tube inspections which fall into Category $\mathrm{C}-3$ and require prompt notification of the Commission shall be reported pursuant to Specification 6.9.1 prior to resumption of plant operation. The written followup of this report shall provide a description of investigations conducted to determine cause of the tube degradation and corrective measures taken to prevent recurrence. 
TABLE 4.4-1

MINIMUM NUMBER OF STEAM GENERATORS TO BE

INSPECTED DURING INSERVICE INSPECTION

\begin{tabular}{|c|c|c|c|c|c|c|}
\hline Preservice Inspection & \multicolumn{3}{|c|}{ No } & \multicolumn{3}{|c|}{ Yes } \\
\hline No of Steam Generators per Unit & Two & Three & Four & Two & Three & Four \\
\hline First Inservice Inspection & \multicolumn{3}{|c|}{ All } & One & Two & Two \\
\hline Second \& Subsequent Inservice Inspections & \multicolumn{3}{|c|}{ One ${ }^{1}$} & One ${ }^{1}$ & One ${ }^{2}$ & One ${ }^{3}$ \\
\hline
\end{tabular}

\section{Table Notation}

1 The inservice inspection may be limited to one steam generator on a rotatıng schedule encompassing $3 \mathrm{~N} \%$ of the tubes (where $\mathrm{N}$ is the number of steam generators in the plant) if the results of the first or previous inspections indicate that all steam generators are performing in a like manner Note that under some circumstances, the operatıng conditions in one or more steam generators may be found to be more severe than those in other steam generators Under such circum stances the sampla sequence shall be modified to inspect the most severe conditions

2 The other steam generator not inspected during the first inservice inspection shall be inspected The third and subsequent inspections should follow the instructions described in 1 above

3 Each of the other two steam generators not inspected durıng the first inservice inspections shall be inspected durıng the second and third inspections The fourth and subsequent inspections shall follow the instructions described in 1 above 
TABLE 4.4-2

STEAM GENERATOR TUBE INSPECTION

\begin{tabular}{|c|c|c|c|c|c|c|}
\hline \multicolumn{3}{|c|}{ 1ST SAMPLE INSPECTION } & \multicolumn{2}{|c|}{ 2ND SAMPLE INSPECTION } & \multicolumn{2}{|c|}{ 3RD SAMPLE INSPECTION } \\
\hline Sample Size & Result & Action Required & Result & Action Required & Result & Action Required \\
\hline \multirow{9}{*}{$\begin{array}{l}\text { A minimum of } \\
S \text { Tubes per } \\
\text { S. G. }\end{array}$} & $\mathrm{C}-1$ & None & $N / A$ & N/A & $N / A$ & $N / A$ \\
\hline & \multirow[t]{5}{*}{$\mathrm{C}-2$} & \multirow{5}{*}{$\begin{array}{l}\text { Plug defective tubes } \\
\text { and inspect additional } \\
2 S \text { tubes in this } S . G .\end{array}$} & $\mathrm{C}-1$ & None & $N / A$ & N/A \\
\hline & & & \multirow{3}{*}{$\mathrm{C}-2$} & \multirow{3}{*}{$\begin{array}{l}\text { Plug defective tubes } \\
\text { and inspect additional } \\
4 S \text { tubes in this } S . G .\end{array}$} & $\mathrm{C}-1$ & None \\
\hline & & & & & $\mathrm{C}-2$ & Plug defective tubes \\
\hline & & & & & $C-3$ & $\begin{array}{l}\text { Perform action for } \\
\text { C-3 result of first } \\
\text { sample }\end{array}$ \\
\hline & & & $\mathrm{C}-3$ & $\begin{array}{l}\text { Perform action for } \\
\text { C-3 result of first } \\
\text { sample }\end{array}$ & N/A & $N / A$ \\
\hline & \multirow[t]{3}{*}{$C-3$} & \multirow{3}{*}{$\begin{array}{l}\text { Inspect all tubes in } \\
\text { this S. G., plug de- } \\
\text { fective tubes and } \\
\text { inspect } 2 S \text { tubes in } \\
\text { each other S. G. } \\
\text { Prompt notification } \\
\text { to NRC pursuant } \\
\text { to specification } \\
6.9 .1\end{array}$} & $\begin{array}{l}\text { All other } \\
\text { S. G.s are } \\
\text { C-1 }\end{array}$ & None & N/A & N/A \\
\hline & & & $\begin{array}{l}\text { Some S. G.s } \\
\mathrm{C}-2 \text { but no } \\
\text { additional } \\
\text { S. G. are } \\
\text { C-3 }\end{array}$ & $\begin{array}{l}\text { Perform action for } \\
\text { C-2 result of second } \\
\text { sample }\end{array}$ & N/A & N/A \\
\hline & & & $\begin{array}{l}\text { Additional } \\
\text { S. G. is } \mathrm{C}-3\end{array}$ & $\begin{array}{l}\text { Inspect all tubes in } \\
\text { each } S . G \text {. and plug } \\
\text { defective tubes. } \\
\text { Prompt notification } \\
\text { to NRC pursuant } \\
\text { to specification } \\
6.9 .1\end{array}$ & N/A & $N / A$ \\
\hline
\end{tabular}
$\mathrm{S}=3 \frac{\mathrm{N}}{\mathrm{n}} \%$ Where $\mathrm{N}$ is the number of steam generators in the unit, and $\mathrm{n}$ is the number of steam generators inspected 
REACTOR COOLANT SYSTEM

3/4.4.6 REACTOR COOLANT SYSTEM LEAKAGE

LEAKAGE DETECTION SYSTEMS

LIMITING CONDITION FOR OPERATION

3.4.6.1 The following Reactor Coolant System leakage detection systems shall be OPERABLE:

a. A containment atmosphere (gaseous or particulate) radioactivity monitoring system,

b. The containment sump level and flow monitoring system, and

c. Either the (containment air cooler condensate flow rate) or a containment atmosphere (gaseous or particulate) radioactivity monitoring system.

APPLICABILITY: MODES $1,2,3$ and 4.

\section{ACTION:}

With only two of the above required leakage detection systems OPERABLE, operation may continue for up to 30 days provided grab samples of the containment atmosphere are obtained and analyzed at least once per 24 hours when the required gaseous and/or particulate radioactivity monitoring system is inoperable; otherwise, be in at least HOT STANDBY within the next 6 hours and in COLD SHUTDOWN within the following 30 hours.

\section{SURVEILLANCE REQUIREMENTS}

4.4.6.1 The leakage detection systems shall be demonstrated OPERABLE by:

a. Containment atmosphere (gaseous and/or particulate) monitoring system-performance of CHANNEL CHECK, CHANNEL CALIBRATION and CHANNEL FUNCTIONAL TEST at the frequencies specified in Table (4.3-3),

b. Containment sump level and flow monitoring system-performance of CHANNEL CALIBRATION at least once per 18 months,

c. (Specify appropriate surveillance tests depending upon the method of leakage detection system selected.) 
REACTOR COOLANT SYSTEM

OPERATIONAL LEAKAGE

3.4.6.2 Reactor Coolant System leakage shall be limited to:

a. No PRESSURE BOUNDARY LEAKAGE,

b. $1 \mathrm{gpm}$ UNIDENTIFIED LEAKAGE,

c. 1 gpm total primary-to-secondary leakage through all steam generators not isolated from the Reactor Coolant System and (500) gallons per day through any one steam generator not isolated from the Reactor Coolant System,

d. $10 \mathrm{gpm}$ IDENTIFIED LEAKAGE from the Reactor Coolant System, and

e. gpm CONTROLLED LEAKAGE at a Reactor Coolant System pressure of 2235 \pm 20 psig.

APPLFCABILITY: MODES $1,2,3$ and 4

ACTION:

a. With any PRESSURE BOUNDARY LEAKAGE, be in at least HOT STANDBY within 6 hours and in COLD SHUTDOWN within the following 30 hours.

b. With any Reactor Coolant System leakage greater than any one of the limits, excluding PRESSURE BOUNDARY LEAKAGE, reduce the leakage rate to within limits within 4 hours or be in at least HOT STANDBY within the next 6 hours and in COLD SHUTDOWN within the following 30 hours.

SURVEILLANCE REQUIREMENTS

4.4.6.2 Reactor Coolant System leakages shall be demonstrated to be within each of the above limits by:

a. Monitoring the containment atmosphere (gaseous or particulate) radioactivity monitor at least once per 12 hours.

b. Monitoring the containment sump inventory and discharge at least once per 12 hours. 


\section{REACTOR COOLANT SYSTEM}

SURVEILLANCE REQUIREMENTS (Continued)

c. Measurement of the CONTROLLED LEAKAGE to the reactor coolant pump seals when the Reactor Coolant System pressure is $2235+20$ psig at least once per 31 days with the modulating valve fully open,

d. Performance of a Reactor Coolant System water inventory balance at least once per 72 hours during steady state operation, and

e. Monitoring the reactor head flange leakoff system at least once per 24 hours. 
REACTOR COOLANT SYSTEM

\subsubsection{CHEMISTRY}

LIMITING CONDITION FOR OPERATION

3.4.7 The Reactor Coolant System chemistry shall be maintained within the limits specified in Table 3.4-1.

APPLICABILITY: At all times.

ACTION:

MODES $1,2,3$ and 4

a. With any one or more chemistry parameter in excess of its Steady State Limit but within its Transient Limit, restore the parameter to within its Steady State Limit within 24 hours or be in at least HOT STANDBY within the next 6 hours and in COLD SHUTDOWN within the following 30 hours.

b. With any one or more chemistry parameter in excess of its Transient Limit, be in at least HOT STANDBY within 6 hours and in COLD SHUTDOWN within the following 30 hours.

MODES 5 and 6

With the concentration of either chloride or fluoride in the Reactor Coolant System in excess of its Steady State Limit for more than 24 hours or in excess of its Transient Limit, reduce the pressurizer pressure to less than or equal to $500 \mathrm{psia}$, if applicable, and perform an engineering evaluation to determine the effects of the out-of-limit condition on the structural integrity of the Reactor Coolant System; determine that the Reactor Coolant System remains acceptable for continued operation prior to increasing the pressurizer pressure above 500 psia or prior to proceeding to MODE 4.

SURVEILLANCE REQUIREMENTS

4.4.7 The Reactor Coolant System chemistry shall be determined to be within the limits by analysis of those parameters at the frequencies specified in Table 4.4-3. 


\section{TABLE 3.4-1}

\section{REACTOR COOLANT SYSTEM}

\section{CHEMISTRY}

PARAMETER

DISSOLVED OXYGEN *

CHLORIDE

FLUORIDE

ॠLimit not applicable with $T_{\text {avg }}$ less than or equal to $250^{\circ} \mathrm{F}$.
TRANSIENT LIMIT

$\leq 0.10 \mathrm{ppm}$

$\leq 1.00 \mathrm{ppm}$

$\leq 0.15 \mathrm{ppm}$

$\leq 1.50 \mathrm{ppm}$

$\leq 1.50 \mathrm{ppm}$ 


\section{TABLE 4. 4-3}

\section{REACTOR COOLANT SYSTEM}

\section{CHEMISTRY LIMITS SURVEILLANCE REQUIREMENTS}

PARAMETER

DISSOLVED OXYGEN ${ }^{*}$

CHLORIDE

FLUORIDE
SAMPLE AND

ANALYSIS FREQUENCY

At least once per 72 hours

At least once per 72 hours

At least once per 72 hours

*Not required with $T_{\text {avg }}$ less than or equal to $250^{\circ} \mathrm{F}$ 
PEACTOR COOLANT SYSTEM

3/4.4.8 SPECIFIC ACTIVITY

LIMITING CONDITION FOR OPERATINN

3.4.8 The specific activity of the primary coolant shall be limited to:

a. Less than or equal to 1.0 microcurie/aram DOSE EOUIVALENT I-131, and

b. Less than or equal to $100 / \bar{E}$ microcuries/gram.

APPLICABILITY: MODES $1,2,3,4$ and 5 .

ACTION:

MODES 1,2 and $3 *$ :

a. With the specific activity of the primary coolant greater than 1.0 microcurie/gram DOSE EOUIVALENT I-131 but within the allowable limit (below and to the left of the line) shown on Fiqure 3.4-1, operation may continue for up to 48 hours provided that the cumulative operating time under these circumstances does not exceed 800 hours in any consecutive 12 month period. With the total cumulative operating time at a primary coolant specific activity greater than 1.0 microcurie/gram DOSF EQUIVALENT I-131 exceeding 500 hours in any consecutive 6 month period, prepare and suhmit a Special Report to the Commission pursuant to Specification 6.9 .2 within 30 days indicating the number of hours above this limit. The provisions of Specification 3.0 .4 are not applicable.

b. With the specific activity of the primary coolant greater than 1.0 microcurie/gram DOSE EQUIVALENT I-131 for more than 48 hours durina one continuous time interval or exceedina the limit line shown on Figure 3.4-1, be in at least HOT STANDBY with Tavg less than $500^{\circ} \mathrm{F}$ within 6 hours.

c. With the specific activity of the primary coolant greater than $100 / F$ microcuries/gram, be in at least HOT STANDBY with $T$ ava less than $500^{\circ} \mathrm{F}$ within 6 hours.

${ }^{\star}$ With $\mathrm{T}_{\text {avg }}$ greater than or equal to $500^{\circ} \mathrm{F}$. 
REACTOR COOLANT SYSTEM

ACTION: (Continued)

MODES $1,2,3,4$ and 5 :

d. With the specific activity of the primary coolant greater than 1.0 microcurie/gram DOSE EQUIVALENT I-131 or greater than 100/E microcuries/gram, perform the sampling and analysis requirements of item 4 a of Table 4.4-4 until the specific activity of the primary coolant is restored to within its limits. A REPORTABLE OCCURRENCE shall be prepared and submitted to the Commission pursuant to Specification 6.9.1. This report shall contain the results of the specific activity analyses together with the following information:

1. Reactor power history starting 48 hours prior to the first sample in which the limit was exceeded,

2. Fuel burnup by core region,

3. Clean-up flow history starting 48 hours prior to the first sample in which the limit was exceeded,

4. History of de-gassing operation, if any, starting 48 hours prior to the first sample in which the limit was exceeded, and

5. The time duration when the specific activity of the primary coolant exceeded 1.0 microcurie/gram DOSE EQUIVALENT I-131.

4.4.8 The specific activity of the primary coolant shall be determined to be within the limits by performance of the sampling and analysis program of Table 4.4-4. 


\section{AND ANALYSIS PROGRAM}

\section{TYPE OF MEASUREMENT} AND ANALYSIS

1. Gross Activity Determination

2. Isotopic Analysis for DOSE EQUIVALENT I-131 Concentration

3. Radiochemical for $\bar{E}$ Determination

4. Isotopic Analysis for Iodine Including I-131, I-133, and I-135

\section{SAMPLE AND ANALYSIS} FREQUENCY

At least once per 72 hours

1 per 14 days

1 per 6 months*

a) Once per 4 hours, whenever the specific activity exceeds 1.0 $\mu \mathrm{Ci} /$ gram, DOSE

EQUIVALENT I-131 or $100 / \bar{E} \mu \mathrm{Ci} / \mathrm{gram}$, and

b) One sample between

2 and 6 hours following

a THERMAL POWER

change exceeding

15 percent of the

RATED THERMAL

POWER within a one

hour period.
MODES IN WHICH SAMPLE AND ANALYSIS REQUIRED

$1,2,3,4$

1

1

1\#, 2\#, 3\#, 4\#, 5\#

\#Until the specific activity of the primary coolant system is restored within its limits.

है
er
ज্

* Sample to be taken after a minimum of 2 EFPD and 20 days of POWER OPERATION have elapsed since reactor was last subcritical for 48 hours or longer. 


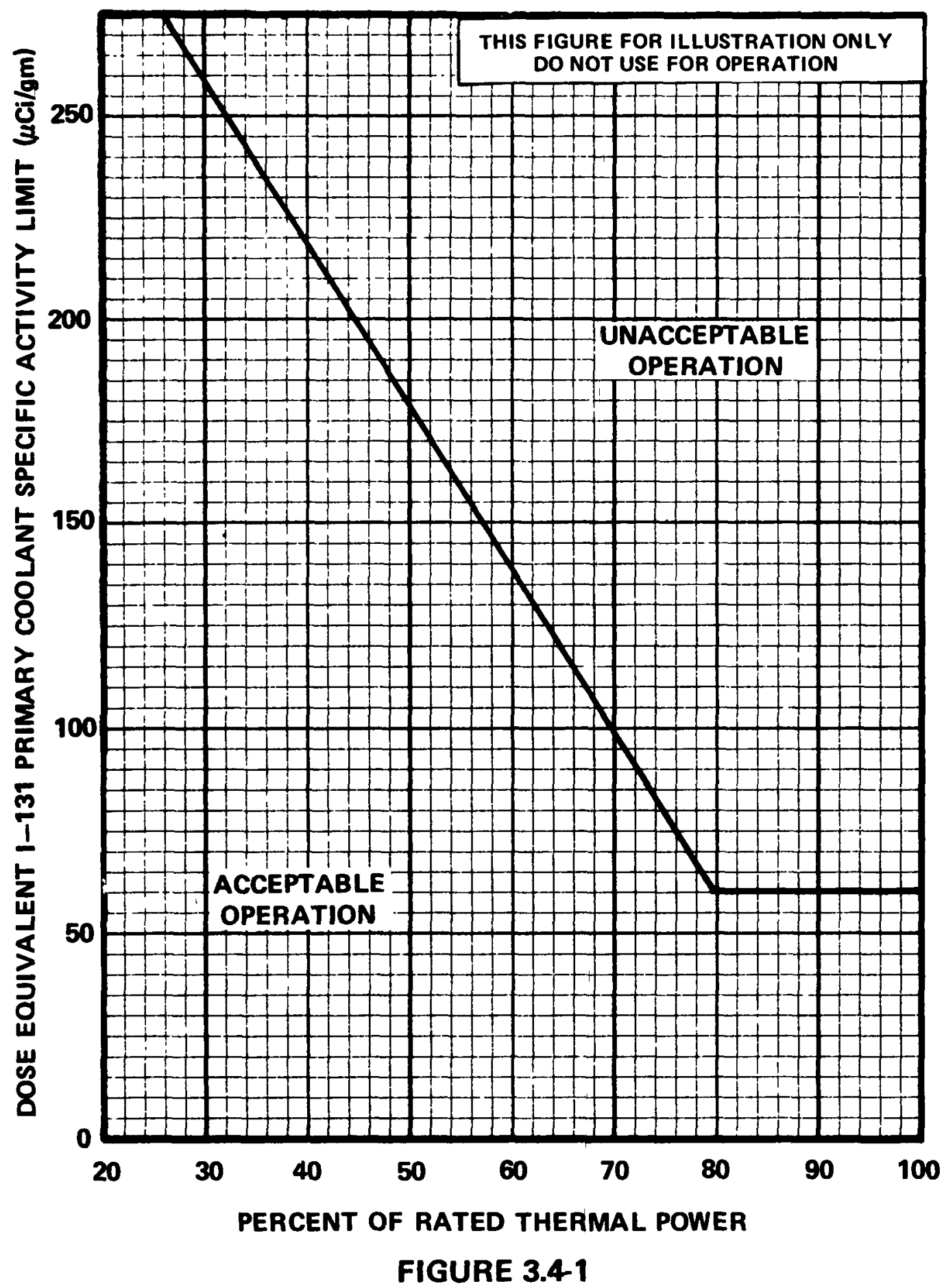

DOSE EQUIVALENT 1-131 Primary Coolant Specific Activity Limit Versus Percent of RATED THERMAL POWER with the Primary Coolant Specific Activity $>1.0 \mu \mathrm{Ci} /$ gram Dose Equivalent I-131 
REACTOR COOLANT SYSTEM

3/4.4.9 PRESSURE/TEMPERATURE LIMITS

REACTOR COOLANT SYSTEM

LIMITING CONDITION FOR OPERATION

3.4.9.1 The Reactor Coolant System (except the pressurizer) temperature and pressure shall be limited in accordance with the limit lines shown on Figure (3.4-2) during heatup, cooldown, criticality, and inservice leak and hydrostatic testing with:

a. A maximum heatup of $(100)^{\circ} \mathrm{F}$ in any one hour period.

b. A maximum cooldown of $(100)^{\circ} \mathrm{F}$ in any one hour period.

c. A maximum temperature change of less than or equal to $(10)^{\circ} \mathrm{F}$ in any one hour period during inservice hydrostatic and leak testing operations above the heatup and cooldown limit curves.

APPLICABILITY: At all times.

ACTION:

With any of the above limits exceeded, restore the temperature and/or pressure to within the limit within 30 minutes; perform an engineering evaluation to determine the effects of the out-of-limit condition on the fracture toughness properties of the Reactor Coolant System; determine that the Reactor Coolant System remains acceptable for continued operations or be in at least HOT STANDBY with in the next 6 hours and reduce the RCS T and pressure to less than $200^{\circ} \mathrm{F}$ and $500 \mathrm{psia}$, respectively, within the folygwing 30 hours.

4.4.9.1.1 The Reactor Coolant System temperature and pressure shall be determined to be within the limits at least once per 30 minutes during system heatup, cooldown, and inservice leak and hydrostatic testing operations.

4.4.9.1.2 The reactor vessel material irradiation surveillance specimens shall be removed and examined, to determine changes in material properties, at the intervals required by 10 CFR 50 Appendix $H$. The results of these examinations shall be used to update Figure 3.4-2. 


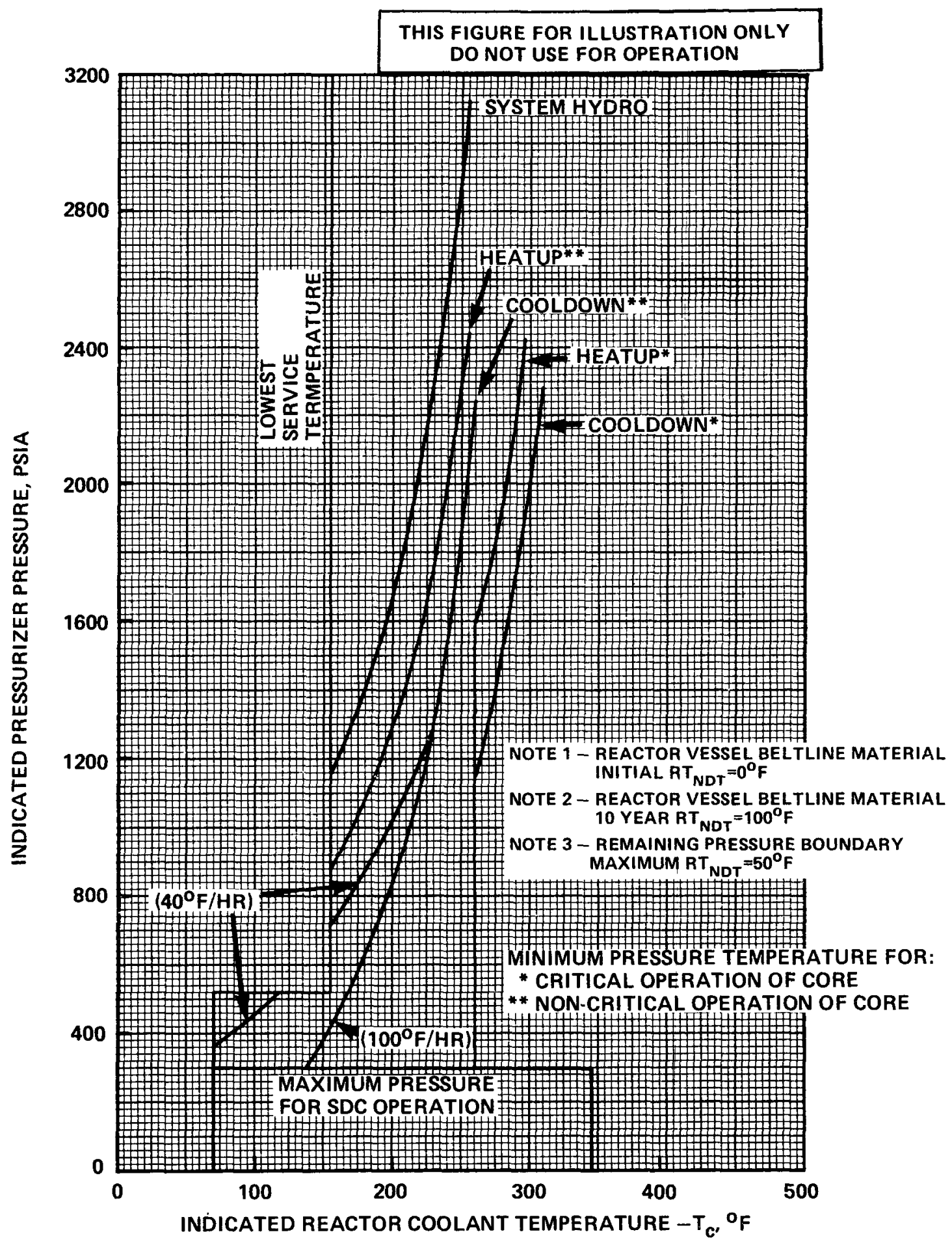

Figure 3.4-2

Reactor Coolant System Pressure Temperature Limitations for 0 to 10 Years of Full Power Operation 
3.4.9.2 The pressurizer temperature shall be limited to:

a. A maximum heatup of $(200)^{\circ} \mathrm{F}$ in any one hour period,

b. A maximum cooldown of $(200)^{\circ} \mathrm{F}$ in any one hour period, and

c. A maximum spray water temperature differential of $(200)^{\circ} \mathrm{F}$.

APPLICABILITY: At all times.

\section{ACTION:}

With the pressurizer temperature limits in excess of any of the ahove limits, restore the temperature to within the limits within 30 minutes; perform an engineering evaluation to determine the effects of the out-of-limit condition on the fracture toughness properties of the pressurizer; determine that the pressurizer remains acceptahle for continued operation or he in at least HOT STANDBY with in the next 6 hours and reduce the pressurizer pressure to less than 500 psig within the following 30 hours.

SURVEILLANCE REQUIREMENTS

4.4.9.2 The pressurizer temperatures shall be determined to be within the limits at least once per 30 minutes during system heatup or cooldown. The spray water temperature differential shall be determined to be within the limit at least once per 12 hours during auxiliary spray operation. 
REACTOR COOLANT SYSTEM

OVERPRESSURE PROTECTION SYSTEMS

LIMITING CONDITION FOR OPERATION

3.4.9.3 At least one of the following overpressure protection systems shall be OPERABLE:

a. Two power operated relief valves (PORVs) with a lift setting of less than or equal to (450) psig, or

b. A reactor coolant system vent of greater than or equal to (1.3) square inches.

APPLICABILITY: When the temperature of one or more of the RCS cold legs is less than or equal to $(275)^{\circ} \mathrm{F}$, except when the reactor vessel head is removed.

ACTION:

a. With one PORV inoperable, either restore the inoperable PORV to OPERABLE status within 7 days or depressurize and vent the RCS through a greater than or equal to (1.3) square inch vent(s) within the next 8 hours; maintain the RCS in a vented condition until both PORVs have been restored to OPERABLE status.

b. With both PORVs inoperable, depressurize and vent the RCS through a greater than or equal to (1.3) square inch vent(s) within 8 hours; maintain the RCS in a vented condition until both PORVs have been restored to OPERABLE status.

c. In the event either the PORVs or the RCS vent(s) are used to mitigate a RCS pressure transient, a Special Report shall be prepared and submitted to the Commission pursuant to Specification 6.9.2 within 30 days. The report shall describe the circumstances initiating the transient, the effect of the PORVs or vent(s) on the transient and any corrective action necessary to prevent recurrence.

d. The provisions of Specification 3.0.4 are not applicable.

4.4.9.3.1 Each PORV shall be demonstrated OPERABLE by:

a. Performance of a CHANNEL FUNCTIONAL TEST on the PORV actuation channel, but excluding valve operation, within 31 days prior to entering a condition in which the PORV is required OPERABLE and at least once per 31 days thereafter when the PORV is required OPERABLE. 
b. Performance of a CHANNEL CALIBRATION on the PORV actuation channel, at least once per 18 months.

c. Verifying the PORV isolation valve is open at least once per 72 hours when the PORV is being used for overpressure protection.

d. Testing in accordance with the inservice test requirements for ASME Category $C$ valves pursuant to Specification 4.0.5.

4.4.9.3.2 The RCS vent(s) shall be verified to be open at least once per 12 hours* when the vent(s) is being used for overpressure protection.

*Except when the vent pathway is provided with a valve which is locked, sealed, or otherwise secured in the open position, then verify these valves open at least once per 31 days. 


\section{4 .10 STRUCTURAL IMTEGRITY}

ASME CODE CLASS 1,2 AND 3 COMPONENTS

\section{LIMITING CONDITION FOR OPERATION}

3.4.10 The structural integrity of ASME Code Class 1, 2 and 3 components shall be maintained in accordance with Specification 4.4.10.

\section{APPLICARILITY: ALL MODES}

\section{ACTION:}

a. With the structural integrity of any ASME Code Class 1 component(s) not conforming to the ahove requirements, restore the structural integrity of the affected component(s) to within its limit or isolate the affected component(s) prior to increasing the Reactor Coolant System temperature more than $50^{\circ} \mathrm{F}$ above the minimum temperature required by NDT considerations.

b. With the structural integrity of any $A S^{M} E$ Code Class 2 component(s) not conforming to the above requirements, restore the structural integrity of the affected component(s) to within its limit or isolate the affected component(s) prior to increasing the Reactor Coolant System temperature above $200^{\circ} \mathrm{F}$.

c. With the structural integrity of any ASME Code Class 3 component(s) not conforming to the above requirements, restore the structural integrity of the affected component to within its limit or isolate the affected component from service.

d. The provisions of Specification 3.0 .4 are not applicable.

4.4.10 In addition to the requirements of Specification 4.0.5, each Reactor Coolant Pump flywheel shall be inspected per the recommendations of Regulatory Position C.4.b of Regulatory Guide 1.14, Revision 1, August 1975. 
3/4.5 EMERGENCY CORE COOLING SYSTEMS (ECCS)

\section{3/4.5.1 SAFETY INJECTION TANKS}

\section{LIMITING CONDITION FOR OPERATION}

3.5.1 Each reactor coolant system safety injection tank shall be OPERABLE with:

a. The isolation valve open,

b. A contained borated water volume of between (1413) and (1539) cubic feet,

c. Between (1731) and (2250) ppm of boron, and

d. A nitrogen cover-pressure of between (600) and (624) psig.

APPLICABILITY: MODES 1,2 and $3 . *$

ACTION:

a. With one safety injection tank inoperable, except as a result of a closed isolation valve, restore the inoperable tank to OPERABLE status within one hour or be in at least HOT STANDBY within the next 6 hours and in HOT SHUTDOWN within the following 6 hours.

b. With one safety injection tank inoperable due to the isolation valve being closed, either immediately open the isolation valve or be in at least HOT STANDBY within one hour and be in HOT SHUTDOWN within the next 12 hours.

\section{SURVEILLANCE REQUIREMENTS}

4.5.1.1 Each safety injection tank shall be demonstrated OPERABLE:

a. At least once per 12 hours by:

1. Verifying (by the absence of alarms) the contained borated water volume and nitrogen cover-pressure in the tanks, and

2. Verifying that each safety injection tank isolation valve is open.

*With pressurizer pressure greater than or equal to (700) psia. 
b. At least once per 31 days and within 6 hours after each solution volume increase of greater than or equal to (1)\% of tank volume by verifying the boron concentration of the safety injection tank solution.

c. At least once per 31 days when the RCS pressure is above (2000) psia, by verifying that power to the isolation valve operator is disconnected by removing the breaker from the circuit.

d. At least once per 18 months by verifying that each safety injection tank isolation valve opens automatically under each of the following conditions:

1. When the RCS pressure exceeds (700) psia, and

2. Upon receipt of a safety injection test signal.

4.5.1.2 Each safety injection tank water level and pressure channel shall be demonstrated OPERABLE:

a. At least once per 31 days by the performance of a CHANNEL FUNCTIONAL TEST.

b. At least once per 18 months by the performance of a CHANNEL CALIBRATION. 
EMERGENCY CORE COOLING SYSTEMS

3/4.5.2 ECCS SUBSYSTEMS - $T_{\text {avg }}$ GREATER THAN OR EOUAL TO $300^{\circ} \mathrm{F}$

LIMITING CONDITION FOR OPERATION

3.5.2 Two independent ECCS subsystems shall be OPERABLE with each subsystem comprised of:

a. One OPERABLE high-pressure safety injection pump,

b. One OPERABLE low-pressure safety injection pump, and

c. An independent OPERABLE flow path capable of taking suction from the refueling water tank on a Safety Injection Actuation Signal and automatically transferring suction to the containment sump on a Sump Recirculation Actuation Signal.

APPLICABILITY: MODES 1,2 and $3 *$.

ACTION:

a. With one ECCS subsystem inoperable, restore the inoperable subsystem to OPERABLE status within 72 hours or be in at least HOT STANDBY with in the next 6 hours and in HOT SHUTDOWN within the following 6 hours.

b. In the event the ECCS is actuated and injects water into the Reactor Coolant System, a Special Report shall be prepared and submitted to the Commission pursuant to Specification 6.9 .2 within 90 days describing the circumstances of the actuation and the total accumulated actuation cycles to date.

*With pressurizer pressure greater than or equal to 1700 psia. 
EMERGENCY CORE COOLING SYSTEMS

SURVEILLANCE REQUIREMENTS

4.5.2 Each ECCS subsystem shall be demonstrated OPERABLE:

a. At least once per 12 hours by verifying that the following valves are in the indicated positions with power to the valve operators removed:

Valve Number

Valve Function

Valve Position

a.

b.

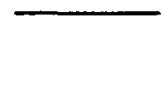

c.

a.

b.

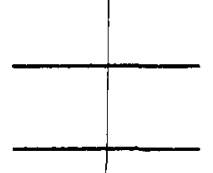

c.

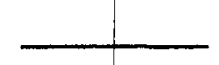

a.

b.

c.

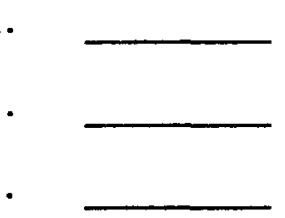

b. At least once per 31 days by verifying that each valve (manual, power operated or automatic) in the flow path that is not locked, sealed, or otherwise secured in position, is in its correct position.

c. By a visual inspection which verifies that no loose debris (rags, trash, clothing, etc.) is present in the containment which could be transported to the containment sump and cause restriction of the pump suctions during LOCA conditions. This visual inspection shall be performed:

1. For all accessible areas of the containment prior to establishing CONTAINMENT INTEGRITY, and

2. Of the areas affected within containment at the completion of containment entry when CONTAINMENT INTEGRITY is established.

d. At least once per 18 months by:

1. Verifying automatic isolation and interlock action of the shutdown cooling system from the Reactor Coolant System when the Reactor Coolant System pressure is above (300) psia. 
EMERGENCY CORE COOLING SYSTEMS

SURVEILLANCE REQUIREMENTS (Continued)

2. A visual inspection of the containment sump and verifying that the subsystem suction inlets are not restricted by debris and that the sump components (trash racks, screens, etc.) show no evidence of structural distress or corrosion.

3. Verifying that a minimum total of (65) cubic feet of solid granular trisodium phosphate dodecahydrate (TSP) is contained within the TSP storage baskets.

4. Verifying that when a representative sample of Ibs of TSP from a TSP storage basket is submerged, without $\overline{\text { agitation, }}$ in $\ldots$ gallons of $\pm+{ }^{\circ} \mathrm{F}$ borated water from the RWT, the pH of the mixed solution is raised to greater than or equal to 6 within 4 hours.

e. At least once per 18 months, during shutdown, by:

1. Verifying that each automatic valve in the flow path actuates to its correct position on (SIAS and RAS) test signal(s).

2. Verifying that each of the following pumps start automatically upon receipt of a Safety Injection Actuation Test Signal:

a. High-Pressure Safety Injection pump.

b. Low-Pressure Safety Injection pump.

3. Verifying that on a Sump Recirculation Actuation Test Signal, the containment sump isolation valves open and the recirculation valve to the refueling water tank closed.

f. By verifying that each of the following pumps develops the indicated discharge pressure on recirculation flow when tested pursuant to Specification 4.0.5:

1. High-Pressure Safety Injection pump greater than or equal to psig.

2. Low-Pressure Safety Injection pump greater than or equal to psig. 
g. By verifying the correct position of each electrical and/or mechanical position stop for the following ECCS throttle valves:

1. Within 4 hours following completion of each valve stroking operation or maintenance on the valve when the ECCS subsystems are required to be OPERABLE.

2. At least once per 18 months.

HPSI System

Valve Number

a.

b.

c.

d.
LPSI System

Valve Number

a.

b.

c.

d.

h. By performing a flow balance test, during shutdown, following completion of modifications to the ECCS subsystems that alter the subsystem flow characteristics and verifying the following flow rates:

HPSI System - Single Pump

a. Injection Leg I, greater than or equal to _ gpm

b. Injection Leg 2, greater than or equal to _ gpm

c. Injection Leg 3 , greater than or equal to __ gpm

d. Injection Leg 4, greater than or equal to __ gpm

\section{LPSI System - Single Pump}

a. Injection Leg 1, greater than or equal to __ gpm

b. Injection Leg 2, greater than or equal to __ gpm

c. Injection Leg 3, greater than or equal to _

d. Injection Leg 4 , greater than or equal to __ gpm 
EMERGENCY CORE COOLING SYSTEMS

$3 / 4.5 .3$ ECCS SUBSYSTEMS - T avg LESS THAN $300^{\circ} \mathrm{F}$

\section{LIMITING CONDITION FOR OPERATION}

3.5.3 As a minimum, one ECCS subsystem comprised of the following shall be OPERABLE:

a. One $e^{\#}$ OPERABLE high-pressure safety injection pump, and

b. An OPERABLE flow path capable of taking suction from the refueling water tank on a Safety Injection Actuation Signal and automatically transferring suction to the containment sump on a Sump Recirculation Actuation Signal.

APPLICABILITY: MODES $3 *$ and 4.

ACTION:

a. With no ECCS subsystem OPERABLE, restore at least one ECCS subsystem to OPERABLE status within 1 hour or be in COLD SHUTDOWN within the next 20 hours.

b. In the event the ECCS is actuated and injects water into the Reactor Coolant System, a Special Report shall be prepared and submitted to the Commission pursuant to Specification 6.9.2 within 90 days describing the circumstances of the actuation and the total accumulated actuation cycles to date.

SURVEILLANCE REQUIREMENTS

4.5.3.1 The ECCS subsystem shall be demonstrated OPERABLE per the applicable Surveillance Requirements of 4.5.2.

4.5.3.2 A11 high-pressure safety injection pumps, except the above required OPERABLE pump, shall be demonstrated inoperable at least once per 12 hours whenever the temperature of one or more of the RCS cold legs is less than or equal to $(275)^{\circ} \mathrm{F}$ by verifying that the motor circuit breakers have been removed from their electrical power supply circuits.

*With pressurizer pressure less than 1700 psia.

\#A maximum of one high-pressure safety injection pump shall be OPERABLE whenever the temperature of one or more of the RCS cold legs is less than or equal to $(275)^{\circ} \mathrm{F}$. 


\section{3/4.5.4 REFUELING WATER TANK}

3.5.4 The refueling water tank shall be OPERABLE with:

a. A contained borated water volume of between $(464,900)$ and $(500,500)$ gallons,

b. Between (1731) and (2250) ppm of boron, and

c. A minimum water temperature of $(35)^{\circ} \mathrm{F}$.

APPLICABILITY: MODES 1,2, 3 and 4.

ACTION:

With the refueling water tank inoperable, restore the tank to OPERABLE status within 1 hour or be in at least HOT STANDBY within 6 hours and in COLD SHUTDOWN within the following 30 hours.

4.5.4 The RWT shall be demonstrated OPERABLE:

a. At least once per 7 days by:

1. Verifying the contained borated water volume in the tank, and

2. Verifying the boron concentration of the water.

b. At least once per 24 hours by verifying the RWT temperature when the (outside) air temperature is less than $35^{\circ} \mathrm{F}$. 
SECTION $3 / 4.6 \mathrm{~F}$

CONTAINMENT SYSTEMS SPECIFICATIONS

FOR

COMBUSTION ENGINEERING

ATMOSPHERIC TYPE CONTAINMENT 

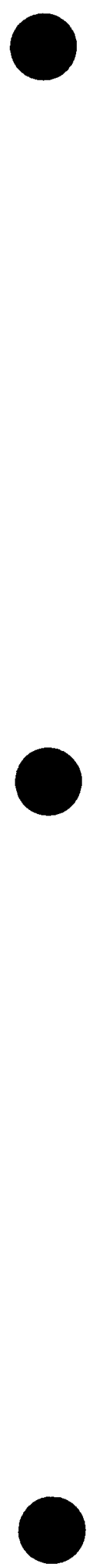
3/4.6 CONTAINMENT SYSTEMS

3/4.6.1 PRIMARY CONTAINMENT

CONTAINMENT INTEGRITY

LIMITING CONDITION FOR OPERATION

3.6.1.1 Primary CONTAINMENT INTEGRITY shall be maintained.

APPLICABILITY: MODES $1,2,3$ and 4.

ACTION:

Without primary CONTAINMENT INTEGRITY, restore CONTAINMENT INTEGRITY within one hour or be in at least HOT STANDBY within the next 6 hours and in COLD SHUTDOWN within the following 30 hours.

SURVEILLANCE REQUIREMENTS

4.6.1.1 Primary CONTAINMENT INTEGRITY shall be demonstrated:

a. At least once per 31 days by verifying that all penetrations* not capable of being closed by OPERABLE containment automatic isolation valves and required to be closed during accident conditions are closed by valves, blind flanges, or deactivated automatic valves secured in their positions, except as provided in Table 3.6-1 of Specification (3.6.4).

b. By verifying that each containment air lock is OPERABLE per Specification (3.6.1.3).

c. After each closing of the equipment hatch, by leak rate testing the equipment hatch seals with gas at $P_{3}$ (54 psig) and verifying that when the measured leakage rate for these seals is added to the leakage rates determined pursuant to Specification 4.6.1.2.d for all other Type $B$ and $C$ penetrations, the combined leakage rate is less than or equal to $0.60 \mathrm{~L}_{\mathrm{a}}$.

*Except valves, blind flanges, and deactivated automatic valves which are located inside the containment and are locked, sealed or otherwise secured in the closed position. These penetrations shall be verified closed during each COLD SHUTDOWN except that such verification need not be performed more often than once per 92 days. 
CONTAINMENT SYSTEMS

CONTAINMENT LEAKAGE

LIMITING CONDITION FOR OPERATION

3.6.1.2 Containment leakage rates shall be 1 imited to:

a. An overall integrated leakage rate of:

1. Less than or equal to $L_{2},(0.10)$ percent by weight of the containment air per 24 hours at $P_{a}$, (54 psig), or

2. Less than or equal to $L_{t},(0.05)$ percent by weight of the containment air per 24 hours at a reduced pressure of $P_{t}$, psig).

b. A combined leakage rate of less than or equal to $0.60 \mathrm{~L}$ for all penetrations and valves subject to Type $B$ and $C$ tests, When pressurized to $P_{a}$.

APPLICABILITY: MODES $1,2,3$ and 4.

ACTION:

With either (a) the measured overall integrated containment leakage rate exceeding $0.75 \mathrm{~L}$ or $0.75 \mathrm{~L}$, as applicable, or (b) with the measured combined leakage rate for ${ }^{a} 11$ penetrations and valves subject to Types $B$ and $C$ tests exceeding $0.60 \mathrm{~L}_{\mathrm{a}}$, restore the overall integrated leakage rate to less than or equal to $0.75 \mathrm{~L}^{a}$ or less than or equal to $0.75 \mathrm{~L}_{t}$, as applicable, and the combined leakage rate for all penetrations and valves subject to Type $B$ and $C$ tests to less than or equal to $0.60 \mathrm{~L}$ a prior to increasing the Reactor Coolant System temperature above $200^{\circ} \mathrm{F}$.

4.6.1.2 The containment leakage rates shall be demonstrated at the following test schedule and shall be determined in conformance with the criteria specified in Appendix $J$ of 10 CFR 50 using the methods and provisions of ANSI N45.4 - (1972):

a. Three Type A tests (Overal1 Integrated Containment Leakage Rate) shall be conducted at $40 \pm 10$ month intervals during shutdown at either $P_{\text {a }}$ (54 psig) or at $P_{t}$ (27 psig) during each 10-year service period. "The third test of each set shall be conducted during the shutdown for the 10-year plant inservice inspection. 


\section{SURVEILLANCE REQUIREMENTS (Continued)}

b. If any periodic Type A test fails to meet either $.75 \mathrm{~L}$ or $.75 \mathrm{~L}$, the test schedule for subsequent Type $A$ tests shail be reviewed and approved by the Commission. If two consecutive Type $A$ tests fail to meet either $.75 \mathrm{~L}$ or $.75 \mathrm{~L}$, a Type $A$ test shall be performed at least every 18 mohths until two consecutive Type A tests meet either $.75 \mathrm{~L}_{\mathrm{a}}$ or $.75 \mathrm{~L}_{t}$ at which time the above test schedule may be resumed.

c. The accuracy of each Type A test shall he verified by a supplemental test which:

1. Confirms the accuracy of the Type A test by verifying that the difference between supplemental and Type $A$ test data is within $0.25 \mathrm{~L}_{a}$ or $0.25 \mathrm{~L}_{\mathrm{t}}$.

2. Has a duration sufficient to establish accurately the change in leakage rate between the Type $A$ test and the supplemental test.

3. Requires the quantity of gas injected into the containment or bled from the containment during the supplemental test to be equivalent to at least 25 percent of the total measured leakage at $\mathrm{P}_{\mathrm{a}}(54 \mathrm{psig})$ or $\mathrm{P}_{t}(27 \mathrm{psig})$.

d. Type $B$ and $C$ tests shall be conducted with gas at $P_{\text {( }}$ (54 psig) at intervals no greater than 24 months except for tests involving:

1. Air locks,

2. Penetrations using continuous leakage monitoring systems, and

3. Valves pressurized with fluid from a seal system.

e. Air locks shall be tested and demonstrated OPERABLE per Surveillance Requirement 4.6.1.3.

f. Type B periodic tests are not required for penetrations continuously monitored by the Containment Isolation Valve and Channel Weld Pressurization Systems, provided the systems are OPERABLE per Surveillance Requirement 4.6.1.4.

g. Leakage from isolation valves that are sealed with fluid from a seal system may be excluded, subject to the provisions of Appendix $J$, Section III.C.3, when determining the combined leakage rate provided the seal system and valves are pressurized to at least $1.10 P_{3} \quad(59.4$ psig) and the seal system capacity is adequate to maintain system pressure for at least 30 days. 
h. Type $B$ tests for penetrations employing a continuous leakage monitoring system shall be conducted at $\mathrm{P}_{\mathrm{a}}$ (54 psig) at intervals no greater than once per 3 years.

i. All test leakage rates shall be calculated using observed data converted to absolute values. Error analyses shall he performed to select a balanced integrated leakage measurement system.

j. The provisions of Specification 4.0 .2 are not applicable. 
CONTAINMENT SYSTEMS

CONTAINMENT AIR LOCKS

LIMITING CONDITION FOR OPERATION

3.6.1.3 Each containment air lock shall be OPERABLE with:

a. Both doors closed except when the air lock is being used for normal transit entry and exit through the containment, then at least one air lock door shall be closed, and

b. An overall air lock leakage rate of less than or equal to $0.05 \mathrm{~L}_{\mathrm{a}}$ at $P_{a}$, (54 psig).

APPLICABILITY: MODES $1,2,3$ and 4.

ACTION:

a. With one containment air lock door inoperable:

1. Maintain at least the OPERABLE air lock door closed and either restore the inoperable air lock door to OPERABLE status within 24 hours or lock the OPERABLE air lock door closed.

2. Operation may then continue until performance of the next required overall air lock leakage test provided that the OPERABLE air lock door is verified to be locked closed at least once per 31 days.

3. Otherwise, be in at least HOT STANDBY within the next 6 hours and in COLD SHUTDOWN within the following 30 hours.

4. The provisions of Specification 3.0.4 are not applicable.

b. With the containment air lock inoperable, except as the result of an inoperable air lock door, maintain at least one air lock door closed; restore the inoperable air lock to OPERABLE status within 24 hours or be in at least HOT STANDBY within the next 6 hours and in COLD SHUTDOWN within the following 30 hours.

SURVEILLANCE REQUIREMENTS

4.6.1.3 Each containment air lock shall be demonstrated OPERABLE: 
a. *After each opening, except when the air lock is being used for multiple entries, then at least once per 72 hours, by verifying no detectable seal leakage by pressure decay when the volume between the door seals is pressurized to greater than or equal to $\mathrm{P}_{\mathrm{a}}$ (54 psig) for at least 15 minutes,

b. At least once per 6 months $^{\#}$ by conducting an overall air lock leakage test at $P_{\text {a }}$ (54 psig) and by verifying that the overall air lock leakage rate is within its limit, and

c. At least once per 6 months by verifying that only one door in each air lock can be opened at a time.

*Exemption to Appendix $\mathrm{J}$ of 10 CFR 50.

\# The provisions of Specification 4.0.2 are not applicable. 
CONTAINMENT ISOLATION VALVE AND CHANNEL WELD PRESSURIZATION SYSTEMS (OPTIONAL)

3.6.1.4 The containment isolation valve and channel weld pressurization systems shal] be OPERABLE.

APPLICABILITY: MODES $1,2,3$ and 4.

\section{ACTION:}

With the containment isolation valve or channel weld pressurization system inoperable, restore the inoperable system to OPERABLE status within 7 days or be in at least HOT STANDBY within the next 6 hours and in COLD SHUTDOWN within the following 30 hours.

4.6.1.4.1 The containment isolation valve pressurization system shall be demonstrated OPERABLE at least once per 31 days by verifying that the system is pressurized to greater than or equal to $1.10 \mathrm{P}(59.4 \mathrm{psig})$ and has adequate capacity to maintain system pressure for at least $\mathrm{a}_{30}$ days.

4.6.1.4.2 The containment channel weld pressurization system shall be demonstrated OPERABLE at least once per 31 days by verifying that the system is pressurized to greater than or equal to $\mathrm{P}_{\text {( }}$ ( $54 \mathrm{psig}$ ) and has adequate capacity to maintain system pressure for at least 30 days. 
3.6.1.5 Primary containment internal pressure shall be maintained between and PSIG.

APPLICABILITY: MODES $1,2,3$ and 4.

ACTION:

With the containment internal pressure outside of the limits above, restore the internal pressure to within the limits within 1 hour or be in at least HOT STANDBY within the next 6 hours and in COLD SHUTDOWN within the following 30 hours.

4.6.1.5 The primary containment internal pressure shall be determined to within the limits at least once per 12 hours. 


\section{CONTAINMENT SYSTEMS}

\section{AIR TEMPERATURE}

3.6.1.6 Primary containment average air temperature shall not exceed ${ }^{\circ} \mathrm{F}$. APPLICABILITY: MODES 1, 2, 3 and 4 .

ACTION:

With the containment average air temperature greater than __ ${ }^{\circ} \mathrm{F}$, reduce the average air temperature to within the limit within 8 hours, or be in at least HOT STANDBY within the next 6 hours and in COLD SHUTDOWN within the following 30 hours.

\section{SURVEILLANCE REQUIREMENTS}

4.6.1.6 The primary containment average air temperature shall be the arithmetical average of the temperatures at the following locations and shall be determined at least once per 24 hours:

\section{Location}
a.
b.
c.
d.
e. 


\section{CONTAINMENT SYSTEMS}

CONTAINMENT STRUCTURAL INTEGRITY (Prestressed concrete containment with ungrouted tendons and typica $T$ dome.)

3.6.1.7 The structural integrity of the containment shall be maintained at a level consistent with the acceptance criteria in Specification 4.6.1.7.

APPLICABILITY: MODES 1, 2, 3 and 4.

ACTION:

With the structural integrity of the containment not conforming to the above requirements, restore the structural integrity to within the 1 imits within 24 hours or be in at least HOT STANDBY within the next 6 hours and in COLD SHUTDOWN within the following 30 hours.

\section{SURVEILLANCE REQUIREMENTS}

4.6.1.7.1 Containment Tendons The containment tendons' structural integrity shall be demonstrated at the end of one, three and five years following the initial containment structural integrity test and at five year intervals thereafter. The tendons' structural integrity shall be demonstrated by:

a. Determining that a representative sample* of at least 21 tendons ( 6 dome, 5 vertical, and 10 hoop) each have a lift off force of between (minimum) and (maximum) pounds at the first year inspection. For subsequent inspections, the maximum allowable lift off force shall be decreased from the value determined at the first year inspection by the amount: $\quad \log t$ and the minimum allowable lift off force shall be decreased from the value determined at the first year inspection by the amount: $\quad \log t$ where $t$ is the time interval in years from initial tensioning of the tendon to the current testing date. This test shall include an unloading cycle in which each of these tendons is detensioned to determine if any wires or strands

FFor each inspection, the tendons shall be selected on a random but representative basis so that the sample group will change somewhat for each inspection; however, to develop a history of tendon performance and to correlate the observed data, one tendon from each group (dome, vertical, and hoop) may be kept unchanged after the initial selection. 
are broken or damaged. Tendons found acceptable during this test shall be retensioned to their observed 1 ift off force, $\pm 3 \%$. During retensioning of these tendons, the change in load and eTongation shall be measured simultaneously. If the $1 \mathrm{ift}$ off force of any one tendon in the total sample population is out of the predicted bounds (less than minimum or greater than maximum), an adjacent tendon on each side of the defective tendon shall also be checked for lift off force. If both of these adjacent tendons are found acceptable, the surveillance program may proceed considering the single deficiency as unique and acceptable. This single tendon shall be restored to the required level of integrity. More than one defective tendon out of the original sample population is evidence of abnormal degradation of the containment structure. Unless there is evidence of abnormal degradation of the containment tendons during the first three tests of the tendons, the number of tendons checked for lift off force and change in elongation during subsequent tests may be reduced to a representative sample of at least 9 tendons ( 3 dome, 3 vertical and 3 hoop).

b. Removing one wire or strand from each of a dome, vertical and hoop tendon checked for lift off force and determining that over the entire length of the removed wire or strand that:

1. The tendon wires or strands are free of corrosion, cracks and damage.

2. There are no changes in the presence or physical appearance of the sheathing filler grease.

3. A minimum tensile strength value of psi (guaranteed ultimate strength of the tendon materiai) for at least three wire or strand samples (one from each end and one at mid-length) cut from each removed wire or strand. Failure of any one of the wire or strand samples to meet the minimum tensile strength test is evidence of abnormal degradation of the containment structure.

4.6.1.7.2 End Anchorages and Adjacent Concrete Surfaces The structural integrity of the end anchorages of all tendons inspected pursuant to Specification 4.6.1.7.1 and the adjacent concrete surfaces shall be demonstrated by determining through inspection that no apparent changes have occurred in the visual appearance of the end anchorage or the concrete crack patterns adjacent to the end anchorages. Inspections of the concrete shall be performed during the Type $A$ containment leakage rate tests (reference Specification 4.6.1.2) while the containment is at its maximun test pressure. 
4.6.1.7.3 Containment Surfaces The structural integrity of the exposed accessible interior and exterior surfaces of the containment, including the liner plate, shall be determined during the shutdown for each Type $A$ containment leakage rate test (reference Specification 4.6.1.2) by a visual inspection of these surfaces and verifying no apparent changes in appearance or other abnormal degradation.

4.6.1.7.4 Reports Any abnormal degradation of the containment structure detected during the above required tests and inspections shall be reported to the Commission pursuant to Specification 6.9.1. This report shall include a description of the tendon condition, the condition of the concrete (especially at tendon anchorages), the inspection procedure, the tolerances on cracking, and the corrective actions taken. 


\section{CONTAINMENT SYSTEMS}

CONTAINMENT STRUCTURAL INTEGRITY (Prestressed concrete containment with ungrouted tendons and hemispherical dome.)

3.6.1.7 The structural integrity of the containment shall be maintained at a level consistent with the acceptance criteria in Specification 4.6.1.7.

APPLICABILITY: MODES $1,2,3$ and 4.

ACTION:

With the structural integrity of the containment not conforming to the above requirements, restore the structural integrity to within the limits within 24 hours or be in at least HOT STANDBY within the next 6 hours and in COLD SHUTDOWN within the following 30 hours.

\section{SURVEILLANCE REQUIREMENTS}

4.6.1.7.1 Containment Tendons The containment tendons' structural integrity shall be demonstrated at the end of one, three and five years following the initial containment structural integrity test and at five year intervals thereafter. The tendons' structural integrity shall be demonstrated by:

a. Determining that a representative sample* of at least $4 \%$, but no less than 4 , of the $U$ tendons each have a lift off force of between (minimum) and (maximum) pounds at the first year inspec$\overline{\text { tion }}$ and that a representative sample* of a least $4 \%$, but no less than 9 , of the hoop tendons each have a lift off force of between (minimum) and (maximum) pounds at the first year inspection. For subsequent inspections, the maximum allowable lift off forces shall be decreased from the value determined at the first year inspection by the amount: $\log t$ and the minimum allowable lift off force shall be decreased from the value determined at the firt year inspection by the amount: $\quad \log t$ where $t$ is the time interval in years from initial tensioning of the tendon to the current

\footnotetext{
*For each inspection, the tendons shall be selected on a random but representative basis so that the sample group will change somewhat for each inspection; however, to develop a history of tendon performance and to correlate the observied data, one tendon from each group ( $U$ and hoop) may be kept unchanged after the initial selection.
} 
testing date. This test shall include an unloading cycle in which each of these tendons is detensioned to determine if any wires or strands are broken or damaged. Tendons found acceptable during this test shall be retensioned to their observed lift off force, $+3 \%$. During retensioning of these tendons, the change in load and elongation shall be measured simultaneously. If the lift off force of any one tendon in the total sample population is out of the predicted bounds (less than minimum or greater than maximum), an adjacent tendon on each side of the defective tendon shall also be checked for lift off force. If both of these adjacent tendons are found acceptable, the surveillance program may proceed considering the single deficiency as unique and acceptable. This single tendon shall be restored to the required level of integrity. More than one defective tendon out of the original sample population is evidence of abnormal degradation of the containment structure. Unless there is evidence of abnormal degradation of the containment tendons during the first three tests of the tendons, the number of tendons checked for lift off force and change in elongation during subsequent tests may be reduced to a representative sample of at least $2 \%$, but no less than 2 , of the $U$ tendons and a representative sample of at least $2 \%$, but no less than 3 , of the hoop tendons.

b. Removing one wire or strand from one $U$ tendon and one hoop tendon checked for lift off force and determining that over the entire length of the removed wire or strand that:

1. The tendon wires or strands are free of corrosion, cracks and damage.

2. There are no changes in the presence or physical appearance of the sheathing filler grease.

3. A minimum tensile strength value of psi (guaranteed ultimate strength of the tendon material) for at least three wire or strand samples (one from each end and one at mid-length) cut from each removed wire or strand. Failure of any one of the wire or strand samples to meet the minimum tensile strength test is evidence of abnormal degradation of the containment structure. 
CONTAINMENT SYSTEMS

SURVEILLANCE REQUIREMENTS (Continued)

\begin{abstract}
4.6.1.7.2 End Anchorages and Adjacent Concrete Surfaces The structural integrity of the end anchorages of all tendons inspected pursuant to Specification 4.6.1.7.1 and the adjacent concrete surfaces shall be demonstrated by determining through inspection that no apparent changes have occurred in the visual appearance of the end anchorage or the concrete crack patterns adjacent to the end anchorages. Inspections of the concrete shall be performed during the Type A containment leakage rate tests (reference Specification 4.6.1.2) while the containment is at its maximum test pressure.

4.6.1.7.3 Containment Surfaces The structural integrity of the exposed accessible interior and exterior surfaces of the containment, including the liner plate, shall be determined during the shutdown for each Type $A$ containment leakage rate test (reference Specification 4.6 .1 .2 ) by a visual inspection of these surfaces. This inspection shall be performed prior to the Type A containment leakage rate test to verify no apparent changes in appearance or other abnormal degradation.

4.6.1.7.4 Reports Any abnormal degradation of the containment structure detected during the above required tests and inspections shall be reported to the Commission pursuant to Specification 6.9.1. This report shall include a description of the tendon condition, the condition of the concrete (especially at tendon anchorages), the inspection procedure, the tolerances on cracking, and the corrective actions taken.
\end{abstract}


3.6.1.7 The structural integrity of the containment shall be maintained at a level consistent with the acceptance criteria in Specification 4.6.1.7.

APPLICABILITY: MODES $1,2,3$ and 4.

ACTION:

With the structural integrity of the containment not conforming to the above requirements, restore the structural integrity to within the 1 imits within 24 hours or be in at least HOT STANDBY within the next 6 hours and in COLD SHUTDOWN within the following 30 hours.

\section{SURVEILLANCE REQUIREMENTS}

4.6.1.7.1 Containment Surfaces The structural integrity of the exposed accessible interior and exterior surfaces of the containment, including the liner plate, shall be determined during the shutdown for each Type A containment leakage rate test (reference Specification 4.6.1.2) by a visual inspection of these surfaces. This inspection shall be performed prior to the Type A containment leakage rate test to verify no apparent changes in appearance or other abnormal degradation.

4.6.1.7.2 Reports Any abnormal degradation of the containment structure detected during the above required inspections shall be reported to the Commission pursuant to Specification 6.9.1. This report shall include a description of the condition of the concrete, the inspection procedure, the tolerances on cracking, and the corrective actions taken. 
CONTAINMENT SYSTEMS

CONTAINMENT VENTILATION SYSTEM (OPTIONAL*)

LIMITING CONDITION FOR OPERATION

3.6.1.8 The containment purge supply and exhaust isolation valves shall be closed.

APPLICABILITY: MODES $1,2,3$, and 4 .

ACTION:

With one containment purge supply and/or one exhaust isolation valve open, close the open valve(s) within one hour or be in at least HOT STANDBY within the next 6 hours and in COLD SHUTDOWN within the following 30 hours.

4.6.1.8 The containment purge supply and exhaust isolation valves shall be determined closed at least once per 31 days.

This specification may be modified if the facility design conforms to Branch Technical Position CSB 6-4 of the Standard Review Plan. 
3/4.6.2 DEPRESSURIZATION AND COOLING SYSTEMS

CONTAINMENT SPRAY SYSTEM (Credit taken for iodine removal)

LIMITING CONDITION FOR OPERATION

3.6.2.1 Two independent containment spray systems shall be OPERABLE with each spray system capable of taking suction from the RWT on a Containment Spray Actuation Signal and automatically transferring suction to the containment sump on a Sump Recirculation Actuation Signal. Each spray system flow path from the containment sump shall be via an OPERABLE shutdown cooling heat exchanger.

APPLICABILITY: MODES $1,2,3$ and 4.

ACTION:

With one containment spray system inoperable, restore the inoperable spray system to OPERABLE status within 72 hours or be in at least HOT STANDBY within the next 6 hours; restore the inoperable spray system to OPERABLE status within the next 48 hours or be in COLD SHUTDOWN within the following 30 hours.

4.6.2.1 Each containment spray system shall be demonstrated OPERABLE:

a. At least once per 31 days by verifying that each valve (manual, power operated or automatic) in the flow path is positioned to take suction from the RWT on a Containment Pressure--High-High test signal.

b. By verifying, that on recirculation flow, each pump develops a discharge pressure of greater than or equal to tested pursuant to Specification 4.0.5. psig when

c. At least once per 18 months, during shutdown, by:

1. Verifying that each automatic valve in the flow path actuates to its correct position on a test signal.

2. Verifying that upon a Sump Recirculation Actuation Test Signal, the containment sump isolation valves open and that a recirculation mode flow path via an OPERABLE shutdown cooling heat exchanger is established. 
3. Verifying that each spray pump starts automatically on a test signal.

d. At least once per 5 years by performing an air or smoke flow test through each spray header and verifying each spray nozzle is unobstructed. 
CONTAINMENT SYSTEMS

3/4.6.2 DEPRESSURIZATION AND COOLING SYSTEMS

CONTAINMENT SPRAY SYSTEM (No credit taken for iodine removal)

LIMITING CONDITION FOR OPERATION

3.6.2.1 Two independent containment spray systems shall be OPERABLE with each spray system capable of taking suction from the RWT on a Containment Spray Actuation Signal and automatically transferring suction to the containment sump on a Sump Recirculation Actuation Signal. Each spray system flow path from the containment sump shall be via an OPERABLE shutdown cooling heat exchanger.

APPLICABILITY: MODES $1,2,3$ and 4.

ACTION:

a. With one containment spray system inoperable and at least (four) containment cooling fans OPERABLE, restore the inoperable spray system to OPERABLE status within 7 days or be in at least HOT STANDBY within the next 6 hours and in COLD SHUTDOWN within the following 30 hours.

b. With two containment spray systems inoperable and at least (four) containment cooling fans OPERABLE, restore at least one spray system to OPERABLE status within 72 hours or be in at least HOT STANDBY within the next 6 hours and in COLD SHUTDOWN with in the following 30 hours. Restore both spray systems to OPERABLE status within 7 days of initial loss or be in at least HOT STANDBY within the next 6 hours and in COLD SHUTDOWN within the following 30 hours.

c. With one containment spray system inoperable and one group of required containment cooling fans inoperable, restore either the inoperable spray system or the inoperable group of cooling fans to OPERABLE status within 72 hours or be in at least HOT STANDBY within the next 6 hours and in COLD SHUTDOWN within the following 30 hours. Restore both the inoperable spray system and the inoperable group of cooling fans to OPERABLE status within 7 days of initial loss or be in at least HOT STANDBY within the next 6 hours and in COLD SHUTDOWN within the following 30 hours.

SURVEILLANCE REQUIREMENTS

4.6.2.1 Each containment spray system shall be demonstrated OPERABLE: 
a. At least once per 31 days by verifying that each valve (manual, power operated or automatic) in the flow path is positioned to take suction from the RWT on a Containment Pressure--High-High test signal.

b. By verifying, that on recirculation flow, each pump develops a discharge pressure of greater than or equal to tested pursuant to Specification 4.0.5. psig when

c. At least once per 18 months, during shutdown, by:

1. Verifying that each automatic valve in the flow path actuates to its correct position on a test signal.

2. Verifying that upon a Sump Recirculation Actuation Test Signal, the containment sump isolation valves open and that a recirculation mode flow path via an OPERABLE shutdown cooling heat exchanger is established.

3. Verifying that each spray pump starts automatically on a test signal.

d. At least once per 5 years by performing an air or smoke flow test through each spray header and verifying each spray nozzle is unobstructed. 
CONTAINMENT SYSTEMS

SPRAY ADDITIVE SYSTEM (OPTIONAL)

LIMITING CONDITION FOR OPERATION

3.6.2.2 The spray additive system shall be OPERABLE with:

a. A spray additive tank containing a volume of between solution, and gallons of between

b. Two spray additive eductors each capable of adding $\mathrm{NaOH}$ solution from the chemical additive tank to a containment spray system pump flow.

APPLICABILITY: MODES $1,2,3$ and 4.

ACTION:

With the spray additive system inoperable, restore the system to OPERABLE status within 72 hours or be in at least HOT STANDBY within the next 6 hours; restore the spray additive system to OPERABLE status within the next 48 hours or be in COLD SHUTDOWN within the following 30 hours.

SURVEILLANCE REQUIREMENTS

4.6.2.2 The spray additive system shall be demonstrated OPERABLE:

a. At least once per 31 days by verifying that each valve (manual, power operated or automatic) in the flow path that is not locked, sealed, or otherwise secured in position, is in its correct position.

b. At least once per 6 months by:

1. Verifying the contained solution volume in the tank, and

2. Verifying the concentration of the $\mathrm{NaOH}$ solution by chemical analysis.

c. At least once per 18 months, during shutdown, by verifying that each automatic valve in the flow path actuates to its correct position on a test signal. 
d. At least once per 5 years by verifying each solution flow rate (to be determined during pre-operational tests) from the following drain connections in the spray additive system:
1. (Drain line location)
$\pm$ gpm.
2. (Drain line location) \pm gpm. 
CONTAINMENT SYSTEMS

CONTAINMENT COOLING SYSTEM (OPTIONAL) (Credit taken for iodine removal by spray systems )

LIMITING CONDITION FOR OPERATION

3.6.2.3 (Two) independent groups of containment cooling fans shall be OPERABLE with (two) fan systems to each group. (Equivalent to $100 \%$ cooling capacity.)

APPLICABILITY: MODES $1,2,3$ and 4.

ACTION:

a. With one group of the above required containment cooling fans inoperable and both containment spray systems OPERABLE, restore the inoperable group of cooling fans to OPERABLE status within 7 days or be in at least HOT STANDBY within the next 6 hours and in COLD SHUTDOWN within the following 30 hours.

b. With two groups of the above required containment cooling fans inoperable, and both containment spray systems OPERABLE, restore at least one group of cooling fans to OPERABLE status within 72 hours or be in at least HOT STANDBY within the next 6 hours and in COLD SHUTDOWN within the following 30 hours. Restore both above required groups of cooling fans to OPERABLE status within 7 days of initial loss or be in at least HOT STANDBY within the next 6 hours and in COLD SHUTDOWN within the following 30 hours.

c. With one group of the above required containment cooling fans inoperable and one containment spray system inoperable, restore the inoperable spray system to OPERABLE status within 72 hours or be in at least HOT STANDBY within the next 6 hours and in COLD SHUTDOWN within the following 30 hours. Restore the inoperable group of containment cooling fans to OPERABLE status within 7 days of initial loss or be in at least HOT STANDBY within the next 6 hours and in COLD SHUTDOWN within the following 30 hours.

4.6.2.3 Each group of containment cooling fans shall be demonstrated OPERABLE:

a. At least once per 31 days by:

1. Starting each fan group from the control room and verifying that each fan group operates for at least 15 minutes.

2. Verifying a cooling water flow rate of greater than or equal to gpm to each cooler.

b. At least once per 18 months by verifying that each fan group starts automatically on a test signal. 
CONTAINMENT COOLING SYSTEM (OPTIONAL) (No credit taken for iodine removal by spray systems)

\section{LIMITING CONDITION FOR OPERATION}

3.6.2.3 (Two) independent groups of containment cooling fans shall be OPERABLE with (two) fan systems to each group. (Equivalent to $100 \%$ cooling capacity.)

APPLICABILITY: MODES $1,2,3$ and 4.

ACTION:

a. With one group of the above required containment cooling fans inoperable and both containment spray systems OPERABLE, restore the inoperable group of cooling fans to OPERABLE status within 7 days or be in at least HOT STANDBY within the next 6 hours and in COLD SHUTDOWN within the following 30 hours.

b. With two groups of the above required containment cooling fans inoperable and both containment spray systems OPERABLE, restore at least one group of cooling fans to OPERABLE status within 72 hours or be in at least HOT STANDBY within the next 6 hours and in COLD SHUTDOWN within the following 30 hours. Restore both above required groups of cooling fans to OPERABLE status within 7 days of initial loss or be in at least HOT STANDBY within the next 6 hours and in COLD SHUTDOWN within the following 30 hours.

c. With one group of the above required containment cooling fans inoperable and one containment spray system inoperable, restore either the inoperable group of containment cooling fans or the inoperable spray system to OPERABLE status within 72 hours or be in at least HOT STANDBY within the next 6 hours and in COLD SHUTDOWN within the following 30 hours. Restore both the inoperable group of containment cooling fans and the inoperable spray system to OPERABLE status within 7 days of initial loss or be in at least HOT STANDBY within the next 6 hours and in COLD SHUTDOWN within the following 30 hours.

\section{SURVEILLANCE REQUIREMENTS}

4.6.2.3 Each group of containment cooling fans shall be demonstrated OPERABLE:

a. At least once per 31 days by:

1. Starting each fan group from the controi room and verifying that each fan group operates for at least 15 minutes.

2. Verifying a cooling water flow rate of greater than or equal to gpm to each cooler.

b. At least once per 18 months by verifying that each fan group starts automatically on a test signal. 
CONTAINMENT SYSTEMS

3/4.6.3 IODINE CLEANUP SYSTEM (OPTIONAL)

LIMITING CONDITION FOR OPERATION

3.6.3.1 Two independent containment iodine cleanup systems shall be OPERABLE. APPLICABILITY: MODES $1,2,3$ and 4.

ACTION:

With one iodine cleanup system inoperable, restore the inoperable system to OPERABLE status within 7 days or be in at least HOT STANDBY within the next 6 hours and in COLD SHUTDOWN within the following 30 hours.

\section{SURVEILLANCE REQUIREMENTS}

4.6.3.1 Each iodine cleanup system shall be demonstrated OPERABLE:

a. At least once per 31 days on a STAGGERED TEST BASIS by initiating, from the control room, flow through the HEPA filters and charcoal adsorbers and verifying that the system operates for at least 10 hours with the heaters on.

b. At least once per 18 months or (1) after any structural maintenance on the HEPA filter or charcoal adsorber housings, or (2) following painting, fire or chemical release in any ventilation zone communicating with the system by:

1. Verifying that the cleanup system satisfies the in-place testing acceptance criteria and uses the test procedures of Regulatory Positions C.5.a, C.5.c and C.5.d of Regulatory Guide 1.52, Revision 2, March 1978, and the system flow rate is $\pm 10 \%$.

2. Verifying within 31 days after removal that a laboratory analysis of a representative carbon sample obtained in accordance with Regulatory Position C.6.b of Regulatory Guide 1.52, Revision 2, March 1978, meets the laboratory testing criteria of Regulatory Position C.6. a of Regulatory Guide 1.52, Revision 2, March 1978.

3. Verifying a system flow rate of $\mathrm{cfm}+10 \%$ during system operation when tested in accordance with ANNSI N510-1975. 
c. After every 720 hours of charcoal adsorber operation by verifying within 31 days after removal that a laboratory analysis of a representative carbon sample obtained in accordance with Regulatory Position C.6.b of Regulatory Guide 1.52, Revision 2, March 1978, meets the laboratory testing criteria of Regulatory Position C.6.a of Regulatory Guide 1.52, Revision 2, March 1978.

d. At least once per 18 months by:

1. Verifying that the pressure drop across the combined HEPA filters and charcoal adsorber banks is less than (6) inches Water Gauge while operating the system at a flow rate of $\mathrm{cfm} \pm 10 \%$.

2. Verifying that the system starts on either a Safety Injection Actuation Test Signal or on a Containment Pressure - High Test Signal.

3. Verifying that the filter cooling bypass valves can be opened by operator action.

4. Verifying that the heaters dissipate tested in accordance with ANSI N510-1975.

$+$ kw when

e. After each complete or partial replacement of a HEPA filter bank by verifying that the HEPA filter banks remove greater than or equal to (99.95)\%* of the DOP when they are tested in-place in accordance with ANSI N510-1975 while operating the system at a flow rate of $\mathrm{cfm} \pm 10 \%$.

f. After each complete or partial replacement of a charcoal adsorber bank by verifying that the charcoal adsorbers remove greater than or equal to $99.95 \%$ of a halogenated hydrocarbon refrigerant test gas when they are tested in-place in accordance with ANSI N510-1975 while operating the system at a flow rate of $\mathrm{cfm} \pm 10 \%$.

*99.95\% applicable when a filter efficiency of $99 \%$ is assumed in the safety analyses; $99 \%$ when a filter efficiency of $90 \%$ is assumed. 
CONTAINMENT SYSTEMS

3/4.6.4 CONTAINMENT ISOLATION VALVES

LIMITING CONDITION FOR OPERATION

3.6.4 The containment isolation valves specified in Table 3.6-1 shall be OPERABLE with isolation times as shown in Table 3.6-1.

APPLICABILITY: MODES $1,2,3$ and 4.

ACTION:

With one or more of the isolation valve(s) specified in Table 3.6-1 inoperable, maintain at least one isolation valve OPERABLE in each affected penetration that is open and either:

a. Restore the inoperable valve(s) to OPERABLE status within 4 hours, or

b. Isolate each affected penetration within 4 hours by use of at least one deactivated automatic valve secured in the isolation position, or

c. Isolate the affected penetration within 4 hours by use of at least one closed manual valve or blind flange; or

d. Be in at least HOT STANDBY within the next 6 hours and in COLD SHUTDOWN within the following 30 hours.

SURVEILLANCE REQUIREMENTS

4.6.4.1 The isolation valves specified in Table 3.6-1 shall be demonstrated OPERABLE prior to returning the valve to service after maintenance, repair or replacement work is performed on the valve or its associated actuator, control or power circuit by performance of a cycling test and verification of isolation time.

4.6.4.2 Each isolation valve specified in Table 3.6-1 shall be demonstrated OPERABLE during the COLD SHUTDOWN or REFUELING MODE at least once per 18 months by:

a. Verifying that on a containment isolation test signal, each isolation valve actuates to its isolation position. 


\section{CONTAINMENT SYSTEMS}

SURVEILLANCE REQUIREMENTS (Continued)

b. Verifying that on a Containment Radiation-High test signal, all containment purge valves actuate to their isolation position.

4.6.4.3 The isolation time of each power operated or automatic valve of Table 3.6-1 shall be determined to be within its limit when tested pursuant to Specification 4.0.5.

4.6.4.4 Each containment purge isolation valve shall be demonstrated OPERABLE within 24 hours after each closing of the valve, except when the valve is being used for multiple cyclings, then at least once per 72 hours, by verifying that when the measured leakage rate is added to the leakage rates determined pursuant to Specification 4.6.1.2d. for all other Type B and C penetrations, the combined leakage rate is less than or equal to $0.60 \mathrm{~L}_{\mathrm{a}}$. 
TABLE 3.6-1

CONTAINMENT ISOLATION VALVES

VALVE NUMBER

FUNCTION

ISOLATION TIME

悫

A. CONTAINMENT ISOLATION

1.

2.

B. CONTAINMENT PURGE 1.

2.

c. MANUAL

1.

2.

D. OTHER

1.

2.

*May be opened on an intermittent basis under administrative control.

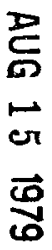

\#Not subject to Type $C$ leakage tests. 
CONTAINMENT SYSTEMS

\section{$3 / 4.6 .5$ COMBUSTIBLE GAS CONTROL}

HYDROGEN ANALYZERS

LIMITING CONDITION FOR OPERATION

3.6.5.1 Two independent containment hydrogen analyzers shall be OPERABLE. APPLICABILITY: MODES $T$ and 2.

ACTION:

With one hydrogen analyzer inoperable, restore the inoperable analyzer to OPERABLE status within 30 days or be in at least HOT STANDBY within the next 6 hours.

4.6.5.1 Each hydrogen analyzer shall be demonstrated OPERABLE at least once per 92 days on a STAGGERED TEST BASIS by performing a CHANNEL CALIBRATION using sample gases containing:

a. One volume percent hydrogen, balance nitrogen, and

b. Four volume percent hydrogen, balance nitrogen. 


\section{CONTAINMENT SYSTEMS}

\section{ELECTRIC HYDROGEN RECOMBINERS - W}

LIMITING CONDITION FOR OPERATION

3.6.5.2 Two independent containment hydrogen recombiner systems shall be OPERABLE.

APPLICABILITY: MODES 1 and 2.

ACTION:

With one hydrogen recombiner system inoperable, restore the inoperable system to OPERABLE status within 30 days or be in at least HOT STANDBY within the next 6 hours.

\section{SURVEILLANCE REQUIREMENTS}

4.6.5.2 Each hydrogen recombiner system shall be demonstrated OPERABLE:

a. At least once per 6 months by veriying during a recombiner system functional test that the minimum heater sheath temperature increases to greater than or equal to $700^{\circ} \mathrm{F}$ within 90 minutes and is maintained for at least 2 hours.

b. At least once per 18 months by:

1. Performing a CHANNEL CALIBRATION of all recombiner instrumentation and control circuits.

2. Verifying through a visual examination that there is no evidence of abnormal conditions within the recombiners (i.e., loose wiring or structural connections, deposits of foreign materials, etc.).

3. Verifying during a recomginer system functional test that the heater sheath temperature increases to greater than or equal to $1200^{\circ} \mathrm{F}$ within 5 hours and is maintained for at least 4 hours.

4. Verifying the integrity of the heater electrical circuits by performing a continuity and resistance to ground test following the above required functional test. The resistance to ground for any heater phase shall be greater than or equal to 10,000 ohms. 
HYDROGEN PURGE CLEANUP SYSTEM (If less than 2 hydrogen recombiners available)

3.6.5.3 A containment hydrogen purge cleanup system shall be OPERABLE and capable of being powered from a minimum of one OPERABLE emergency bus.

\section{APPLICABILITY: MODES 1 and 2.}

ACTION:

With the containment hydrogen purge cleanup system inoperable, restore the hydrogen purge cleanup system to OPERABLE status within 30 days or be in at least HOT STANDBY within the next 6 hours.

\section{SURVEILLANCE REQUIREMENTS}

4.6.5.3 The hydrogen purge cleanup system shall be demonstrated OPERABLE:

a. At least once per 31 days by initiating, from the control room, flow through the HEPA filters and charcoal adsorbers and verifying that the system operates for at least 10 hours with the heaters on.

b. At least once per 18 months or (1) after any structural maintenance on the HEPA filter or charcoal adsorber housings, or (2) following painting, fire or chemical release in any ventilation zone communicating with the system by:

1. Verifying that the cleanup system satisfies the in-place testing acceptance criteria and uses the test procedures of Regulatory Positions C.5.a, C.5.C and C.5.d of Regulatory Guide 1.52, Revision 2, March 1978, and the system flow rate is cfm $\pm 10 \%$.

2. Verifying within 31 days after removal that a laboratory analys is of a representative carbon sample obtained in accordance with Regulatory Position C.6.b of Regulatory Guide 1.52, Revision 2, March 1978, meets the laboratory testing criteria of Regulatory Position C.6.a of Regulatory Guide 1.52, Revision 2, March 1978. 
3. Verifying a system flow rate of $\mathrm{cfm}+10 \%$ during system operation when tested in accordance with ANSI N510-1975.

c. After every 720 hours of charcoal adsorber operation by verifying within 31 days after removal that a laboratory analysis of a representative carbon sample obtained in accordance with Regulatory Position C.6.b of Regulatory Guide 1.52, Revision 2, March 1978, meets the laboratory testing criteria of Regulatory Position C.6.a of Regulatory Guide 1.52, Revision 2, March 1978.

d. At least once per 18 months by:

1. Verifying that the pressure drop across the combined HEPA filters and charcoal adsorber banks is less than (6) inches Water Gauge while operating the system at a flow rate of $c f m \pm 10 \%$.

2. Verifying that the filter cooling bypass valves can be manually opened.

3. Verifying that the heaters dissipate $\quad \pm \ldots$ when tested in accordance with ANSI N510-1975.

e. After each complete or partial replacement of a HEPA filter bank by verifying that the HEPA filter banks remove greater than or equal to (99.95\%) of the DOP when they are tested in-place in accordance with ANSI N510-1975 while operating the system at a flow rate of $\mathrm{cfm} \pm 10 \%$.

f. After each complete or partial replacement of a charcoal adsorber bank by verifying that the charcoal adsorbers remove greater than or equal to $99.95 \%$ of a halogenated hydrocarbon refrigerant test gas when they are tested in-place in accordance with ANSI N510-1975 while operating the system at a flow rate of $\mathrm{cfm} \pm 10 \%$.

*99.95\% applicable when a filter efficiency of $99 \%$ is assumed in the safety analyses; $99 \%$ when a filter efficiency of $90 \%$ is assumed. 


\section{CONTAINMENT SYSTEMS}

HYDROGEN MIXING SYSTEM (OPTIONAL)

LIMITING CONDITION FOR OPERATION

3.6.5.4 Two independent hydrogen mixing systems shall be OPERABLE. APPLICABILITY: MODES 1 and 2.

ACTIÓN:

With one hydrogen mixing system inoperable, restore the inoperable system to OPERABLE status within 30 days or be in at least HOT STANDBY within the next 6 hours.

\section{SURVEILLANCE REQUIREMENTS}

4.6.5.4 Each hydrogen mixing system shall be demonstrated OPERABLE:

a. At least once per 92 days on a STAGGERED TEST BASIS by starting each system from the control room and verifying that the system operates for at least 15 minutes.

b. At least once per 18 months by verifying a system flow rate of at least cfm. 
CONTAINMENT SYSTEMS

3/4.6.6 PENETRATION ROOM EXHAUST AIR CLEANUP SYSTEM (OPTIONAL)

3.6.6 Two independent containment penetration room exhaust air cleanup systems shall be OPERABLE.

APPLICABILITY: MODES $1,2,3$ and 4

ACTION:

With one containment penetration room exhaust air cleanup system inoperable, restore the inoperable system to OPERABLE status within 7 days or be in at least HOT STANDBY within the next 6 hours and in COLD SHUTDOWN within the following 30 hours.

\section{SURVEILLANCE REQUIREMENTS}

4.6.6 Each containment penetration room exhaust air cleanup system shall be demonstrated OPERABLE:

a. At least once per 31 days on a STAGGERED TEST BASIS by initiating, from the control room, flow through the HEPA filters and charcoal adsorbers and verifying that the system operates for at least 10 hours with the heaters on.

b. At least once per 18 months or (1) after any structural maintenance on the HEPA filter or charcoal adsorber housings, or (2) following painting, fire or chemical release in any ventilation zone communicating with the system by:

1. Verifying that with the system operating at a flow rate of $\mathrm{cfm}+10 \%$ and exhausting through the HEPA filters and charcoal adsorbers, the total bypass flow of the system to the facility vent, including leakage through the system diverting valves, is less than or equal to $1 \%$ when the system is tested by admitting cold DOP at the system intake. (For systems with diverting valves.)

2. Verifying that the cleanup system satisfies the in-place testing acceptance criteria and uses the test procedures of Regulatory Positions C.5.a, C.5.c and C.5.d of Regulatory Guide 1.52, Revision 2, March 1978, and the system flow rate is $\mathrm{cfm} \pm 10 \%$. 


\section{SURVEILLANCE REOUIREMENTS (Continued)}

3. Verifying within 31 days after removal that a laboratory analysis of a representative carbon sample obtained in accordance with Regulatory Position C.6.b of Regulatory Guide 1.52, Revision 2, March 1978, meets the laboratory testing criteria of Regulatory Position C.6.a of Regulatory Guide 1.52, Revision 2, March 1978.

4. Verifying a system flow rate of $\mathrm{cfm}+10 \%$ during system operation when tested in accordance with ANSI N510-1975.

c. After every 720 hours of charcoal adsorber operation by verifying within 31 days after removal that a laboratory analys is of a representative carbon sample obtained in accordance with Regulatory Position C.6.b of Regulatory Guide 1.52, Revision 2, March 1978, meets the laboratory testing criteria of Regulatory Position C.6.a of Regulatory Guide 1.52, Revision 2, March 1978.

d. At least once per 18 months by:

1. Verifying that the pressure drop across the combined HEPA filters and charcoal adsorber banks is less than (6) inches Water Gauge while operating the system at a flow rate of $\mathrm{cfm} \pm 10 \%$.

2. Verifying that the system starts on a Safety Injection Actuation Test Signal.

3. Verifying that the filter cooling bypass valves can be manually opened.

4. Verifying that the heaters dissipate $\pm \ldots$ wW when tested in accordance with ANSI N510-1975.

e. After each complete or partial replacement of a HEPA filter bank by verifying that the HEPA filter banks remove greater than or equal to $(99.95 \%)^{*}$ of the DOP when they are tested in-place in accordance with ANSI N510-1975 while operating the system at a flow rate of $\mathrm{cfm} \pm 10 \%$.

f. After each complete or partial replacement of a charcoal adsorber bank by verifying that the charcoal adsorbers remove greater than or equal to $99.95 \%$ of a halogenated hydrocarbon refrigerant test gas when they are tested in-place in accordance with ANSI N510-1975 while operating the system at a flow rate of $\mathrm{cfm} \pm 10 \%$.

ॠ99.95\% applicable when a filter efficiency of $99 \%$ is assumed in the safety analyses; $99 \%$ when a filter efficiency of $90 \%$ is assumed.
CE-ATMOSPHERIC
$3 / 46-37 F$

AUG 151979 
3/4.6.7 VACUUM RELIEF VALVES (OPTIONAL)

3.6.7 The primary containment to atmosphere vacuum relief valves shall be OPERABLE with an actuation set point of less than or equal to PSID.

APPLICABILITY: MODES 1,2,3 and 4.

ACTION:

With one primary containment to atmosphere vacuum rel ief valve inoperable, restore the valve to OPERABLE status within 4 hours or be in at least HOT STANDBY within the next 6 hours and in COLD SHUTDOWN within the following 30 hours.

4.6.7 No additional Surveillance Requirements other than those required by Specification 4.0.5. 
SECTION $3 / 4.6 \mathrm{H}$

CONTAINMENT SYSTEMS SPECIFICATIONS

FOR

COMBUSTION ENGINEERING

DUAL TYPE CONTAINMENT 

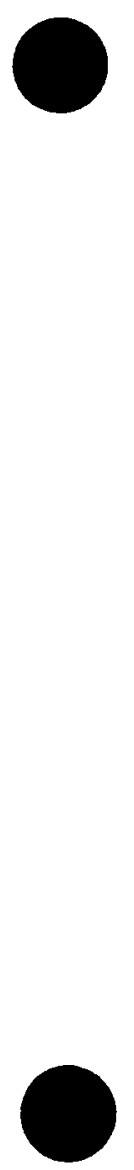

• 
3/4.6 CONTAINMENT SYSTEMS

3/4.6.1 PRIMARY CONTAINMENT

CONTAINMENT INTEGRITY

LIMITING CONDITION FOR OPERATION

3.6.1.1 Primary CONTAIMMENT INTEGRITY shall be maintained.

APPLICABILITY: MODES $1,2,3$ and 4.

ACTION:

Wi thout primary CONTAINMENT INTEGRITY, restore CONTAINMENT INTEGRITY within one hour or be in at least HOT STANDBY within the next 6 hours and in COLD SHUTDOWN within the following 30 hours.

SURVEILLANCE REQUIREMENTS

4.6.1.1 Primary CONTAINMENT INTEGRITY shall be demonstrated:

a. At least once per 31 days by verifying that all penetrations* not capable of being closed by OPERABLE containment automatic isolation valves and required to be closed during accident conditions are closed by valves, blind flanges, or deactivated automatic valves secured in their positions, except as provided in Table $(3.6-2)$ of Specification $(3.6 .4)$.

b. By verifying that each containment air lock is OPERABLE per Specification (3.6.1.3).

c. After each closing of the equipment hatch, by leak rate testing the equipment hatch seals with gas at $P_{2}(50 \mathrm{psig})$ and verifying that when the measured leakage rate for these seals is added to the leakage rates determined pursuant to Specification 4.6.1.2.d for all other Type $B$ and $C$ penetrations, the combined leakage rate is less than or equal to $0.60 \mathrm{~L}_{\mathrm{a}}$.

*Except valves, blind flanges, and deactivated automatic valves which are located inside the containment and are locked, sealed or otherwise secured in the closed position. These penetrations shall be verified closed during each COLD SHUTDOWN except that such verification need not be performed more of ten than once per 92 days. 


\section{CONTAINMENT SYSTEMS}

CONTAINMENT LEAKAGE

LIMITING CONDITION FOR OPERATION

3.6.1.2 Containment leakage rates shall be limited to:

a. An overall integrated leakage rate of:

1. Less than or equal to $L_{2},(0.20)$ percent by weight of the containment air per 24 hours at $\mathrm{P}_{\mathrm{a}}$, (50 psig), or

2. Less than or equal to $L_{t},(0.10)$ percent by weight of the containment air per 24 hours at a reduced pressure of $P_{t}$, psig).

b. A combined leakage rate of less than or equal to $0.60 \mathrm{~L}$ for all penetrations and valves subject to Type $B$ and $C$ tests, when pressurized to $P_{a}$.

c. A combined leakage rate of less of than or equal (0.10) $\mathrm{L}$ for all penetrations identified in Table (3.6-1) as secondary conlainment bypass leakage paths when pressurized to $\mathrm{P}_{\mathrm{a}}$.

APPLICABILITY: MODES $1,2,3$ and 4 .

ACTION:

With either (a) the measured overall integrated containment leakage rate exceeding $0.75 \mathrm{~L}_{\text {a }}$ or $0.75 \mathrm{~L}_{t}$, as applicable, or (b) with the measured combined leakage rate for all penetrations and valves subject to Types $B$ and $C$ tests exceeding $0.60 \mathrm{~L}$, or (c) with the combined bypass leakage rate exceeding $(0.10) L_{2}$, restore the overall integrated leakage rate to less than or equal to $0.75 \mathrm{E}$ or less than or equal to $0.75 \mathrm{~L}$, as applicable, the combined leakage rate for all penetrations and valvess subject to Type $B$ and $C$ tests to less than or equal to $0.60 \mathrm{~L}$, and the bypass leakage rate less than or equal to $(0.10) \mathrm{L}_{a}$ prior to increasing the Reactor Coolant System temperature above $200^{\circ} \mathrm{F}$.

\section{SURVEILLANCE REQUIREMENTS}

4.6.1.2 The containment leakage rates shall be demonstrated at the following test schedule and shall be determined in conformance with the criteria specified in Appendix $J$ of 10 CFR 50 using the methods and provisons of ANSI N45.4-(1972):

a. Three Type A tests (Overall Integrated Containment Leakage Rate) shall be conducted at $40 \pm 10$ month intervals during 
shutdown at either $P_{a}$ (50 psig) or at $P_{t}$ (25 psig) during each 10-year service period. The third test of each set shal1 be conducted during the shutdown for the 10-year plant inservice inspection.

b. If any periodic Type A test fails to meet either $.75 \mathrm{~L}_{\text {a }}$ or $.75 \mathrm{~L}_{t}$, the test schedule for subsequent Type $A$ tests shall be ${ }^{\text {reviewed and }}$ approved by the Commission. If two consecutive Type A tests fail to meet either $.75 \mathrm{~L}$ or $.75 \mathrm{~L}$, a Type $A$ test shall be performed at least every 18 months until two consecutive Type $A$ tests meet either $.75 \mathrm{~L}_{\mathrm{a}}$ or $.75 \mathrm{~L}_{t}$ at which time the above test schedule may be resuméd.

c. The accuracy of each Type A test shall be verified by a supplemental test which:

1. Confirms the accuracy of the Type A test by verifying that the difference between supplemental and Type A test data is within $0.25 \mathrm{~L}_{\mathrm{a}}$ or $0.25 \mathrm{~L}_{\mathrm{t}}$.

2. Has a duration sufficient to establish accurately the change in leakage rate between the type $A$ test and the supplemental test.

3. Requires the quantity of gas injected into the containment or bled from the containment during the supplemental test to be equivalent to at least 25 percent of the total measured leakage at $\mathrm{P}_{\mathrm{a}}(50 \mathrm{psig})$ or $\mathrm{P}_{\mathrm{t}}(25 \mathrm{psig})$.

d. Type $B$ and $C$ tests shall be conducted with gas at $P$ (50 psig) at intervals no greater than 24 months except for tests involving:

1. Air locks,

2. Penetrations using continuous leakage monitoring systems, and

3. Valves pressurized with fluid from a seal system.

e. The combined bypass leakage rate shall be determined to be less than (0.10) $L$ by applicable Type $B$ and $C$ tests at least once per 24 months except for penetrations which are not individually testable; penetrations not individually testable shall be determined to have no detectable leakage when tested with soap bubbles while the containment is pressurized to $P_{a}$ (50 psig) during each Type A test. 
f. Air locks shall be tested and demonstrated OPERABLE per Surveillance Reguirement 4.6.1.3.

g. Type B periodic tests are not required for penetrations continuously monitored by the Containment Isolation Valve and Channel Weld Pressurization Systems provided the systems are OPERABLE per Surveillance Requirement 4.6.1.4.

h. Leakage from isolation valves that are sealed with fluid from a seal system may be excluded, subject to the provisions of Appendix $\mathrm{J}$, Section III.C.3, when determining the combined leakage rate provided the seal system and valves are pressurized to at least $1.10 \mathrm{P}_{\text {(55 }}$ psig) and the seal system capacity is adequate to maintain system pressure for at least 30 days.

i. Type $B$ tests for penetrations employing a continuous leakage monitoring system shall be conducted at $P_{a}$ (50 psig) at intervals no greater than once per 3 years.

j. All test leakage rates shall be calculated using observed data converted to absolute values. Error analyses shall be performed to select a balanced integrated leakage measurement system.

k. The provisions of Specification 4.0.2 are not applicable. 
TABLE 3.6-1

早

SECONDARY CONTAINMENT BYPASS LEAKAGE PATHS

PENETRATION

RELEASE LOCATION

$\underset{\omega}{\omega}$

in

寽

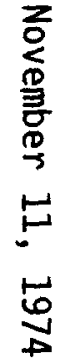


CONTAINMENT SYSTEMS

CONTAINMENT AIR LOCKS

LIMITING CONDITION FOR OPERATION

3.6.1.3 Each containment air lock shall be OPERABLE with:

a. Both doors closed except when the air lock is being used for normal transit entry and exit through the containment, then at least one air lock door shall be closed, and

b. An overall air lock leakage rate of less than or equal to $0.05 \mathrm{~L}_{\mathrm{a}}$ at $P_{a}$, (50 psig).

APPLICABILITY: MODES $1,2,3$ and 4.

ACTION:

a. With one containment air lock door inoperable:

1. Maintain at least the OPERABLE air lock door closed and either restore the inoperable air lock door to OPERABLE status within 24 hours or lock the OPERABLE air lock door closed.

2. Operation may then continue until performance of the next required overall air lock leakage test provided that the OPERABLE air lock door is verified to be locked closed at least once per 31 days.

3. Otherwise, be in at least HOT STANDBY within the next 6 hours and in COLD SHUTDOWN with in the following 30 hours.

4. The provisions of Specification 3.0.4 are not applicable.

b. With the containment air lock inoperable, except as the result of an inoperable air lock door, maintain at least one air lock door closed; restore the inoperable air lock to OPERABLE status within 24 hours or be in at least HOT STANDBY within the next 6 hours and in COLD SHUTDOWN within the following 30 hours.

SURVEILLANCE REQUIREMENTS

4.6.1.3 Each containment air lock shal1 be demonstrated OPERABLE: 


\section{CONTAINMENT SYSTEMS}

\section{SURVEILLANCE REQUIREMENTS (Continued)}

a. *After each opening, except when the air lock is being used for multiple entries, then at least once per 72 hours, by verifying no detectable seal leakage by pressure decay when the volume between the door seals is pressurized to greater than or equal to $P_{a}$ (50 psig) for at least 15 minutes,

b. At least once per 6 months\# by conducting an overall air lock leakage test at $P_{\text {, }}(50 \mathrm{psig}$ ) and by verifying that the overall air lock leakage rate is within its limit, and

c. At least once per 6 months by verifying that only one door in each air lock can be opened at a time.

*Exemption to Appendix $\mathrm{J}$ of 10 CFR 50.

\#The provisions of Specification 4.0.2 are not applicable 
CONTAINMENT ISOLATION VALVE AND CHANNEL WELD PRESSURIZATION SYSTEMS (OPTIONAL)

\section{LIMITING CONDITION FOR OPERATION}

3.6.1.4 The containment isolation valve and channel weld pressurization systems shall be OPERABLE.

APPLICABILITY: MODES $1,2,3$ and 4.

ACTION:

With the containment isolation valve or channel weld pressurization system inoperable, restore the inoperable system to OPERABLE status within 7 days or be in at least HOT STANDBY within the next 6 hours and in COLD SHUTDOWN within the following 30 hours.

4.6.1.4.1 The containment isolation valve pressurization system shall be demonstrated OPERABLE at least once per 31 days by verifying that the system is pressurized to greater than or equal to $1.10 \mathrm{P}$ ( $55 \mathrm{psig}$ ) and has adequate capacity to maintain system pressure for at least 30 days.

4.6.1.4.2 The containment channel weld pressurization system shall be demonstrated OPERABLE at least once per 31 days by verifying that the system is pressurized to greater than or equal to $P_{a}$ ( 50 psig) and has adequate capacity to maintain system pressure for at least 30 days. 
CONTAINMENT SYSTEMS

INTERNAL PRESSURE

3.6.1.5 Primary containment internal pressure shall be maintained between and PSIG.

APPLICABILITY: MODES $1,2,3$ and 4.

\section{ACTION:}

With the containment internal pressure outside of the limits above, restore the internal pressure to within the limits within 1 hour or be in at least HOT STANDBY within the next 6 hours and in COLD SHUTDOWN within the following 30 hours.

4.6.1.5 The primary containment internal pressure shall be determined to within the limits at least once per 12 hours. 
CONTAINMENT SYSTEMS

AIR TEMPERATURE

LIMITING CONDITION FOR OPERATION

3.6.1.6 Primary containment average air temperature shall not exceed ${ }^{\circ} \mathrm{F}$.

APPLICABILITY: MODES $1,2,3$ and 4.

ACTION:

With the containment average air temperature greater than ${ }^{\circ} \mathrm{F}$, reduce the average air temperature to within the limit within 8 hours, or be in at least HOT STANDBY within the next 6 hours and in COLD SHUTDOWN within the following 30 hours.

4.6.1.6 The primary containment average air temperature shall be the arithmetical average of the temperatures at the following locations and shall be determined at least once per 24 hours:

Location

a.

b.

c.

d.

e.

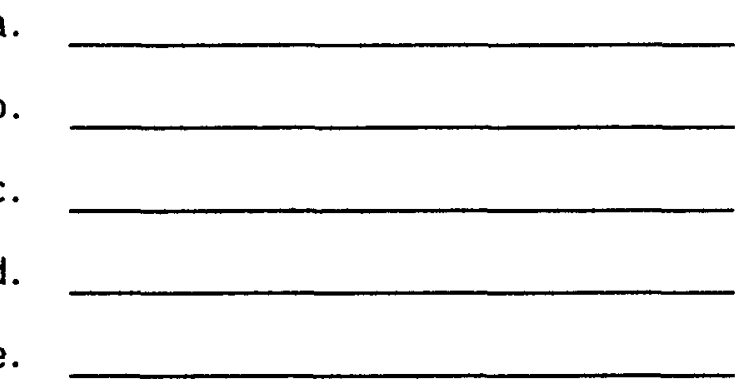


CONTAINMENT SYSTEMS

CONTAINMENT VESSEL STRUCTURAL INTEGRITY

LIMITING CONDITION FOR OPERATION

3.6.1.7 The structural integrity of the containment vessel shall be maintained at a level consistent with the acceptance criteria in Specification 4.6.1.7.

APPLICABILITY: MODES $1,2,3$ and 4.

ACTION:

With the structural integrity of the containment vessel not conforming to the above requirements, restore the structural integrity to within the limits prior to increasing the Reactor Coolant System temperature above $200^{\circ} \mathrm{F}$.

4.6.1.7 The structural integrity of the containment vessel shall be determined during the shutdown for each Type A containment leakage rate test (reference Specification 4.6.1.2) by a visual inspection of the exposed accessible interior and exterior surfaces of the vessel and verifying no apparent changes in appearance of the surfaces or other abnormal degradation. Any abnormal degradation of the containment vessel detected during the above required inspections shall be reported to the Commission pursuant to Specification 6.9.1. 
CONTAINMENT SYSTEMS

CONTAINMENT VENTILATION SYSTEM (OPTIONAL *)

LIMITING CONDITION FOR OPERATION

3.6.1.8 The containment purge supply and exhaust isolation valves shall be closed.

APPLICABILITY: MODES $1,2,3$, and 4.

ACTION:

With one containment purge supply and/or one exhaust isolation valve open, close the open valve(s) within one hour or be in at least HOT STANDBY within the next 6 hours and in COLD SHUTDOWN within the following 30 hours.

4.6.1.8 The containment purge supply and exhaust isolation valves shall be determined closed at least once per 31 days.

FThis specification may be modified if the faciltiy design conforms to Branch Technical Position CSB 6-4 of the Standard Review Plan. 
CONTAINMENT SYSTEMS

3/4.6.2 DEPRESSURIZATION AND COOLING SYSTEMS

CONTAINMENT SPRAY SYSTEM (Credit taken for iodine removal)

LIMITING CONDITION FOR OPERATION

3.6.2.1 Two independent containment spray systems shall be OPERABLE with each spray system capable of taking suction from the RWT on a Containment Spray Actuation Signal and automatically transferring suction to the containment sump on a Sump Recirculation Actuation Signal. Each spray system flow path from the containment sump shall be via an OPERABLE shutdown cooling heat exchanger.

APPLICABILITY: MODES $1,2,3$ and 4.

ACTION:

With one containment spray system inoperable, restore the inoperable spray system to OPERABLE status within 72 hours or be in at least HOT STANDBY within the next 6 hours; restore the inoperable spray system to OPERABLE status within the next 48 hours or be in COLD SHUTDOWN within the following 30 hours.

\section{SURVEILLANCE REQUIREMENTS}

4.6.2.1 Each containment spray system shal1 be demonstrated OPERABLE:

a. At least once per 31 days by verifying that each valve (manual, power operated or automatic) in the flow path is positioned to take suction from the RWT on a Containment Pressure--High-High test signal.

b. By verifying, that on recirculation flow, each pump develops a discharge pressure of greater than or equal to tested pursuant to Specification 4.0.5. psig when

c. At least once per 18 months, during shutdown, by:

1. Verifying that each automatic valve in the flow path actuates to its correct position on a test signal.

2. Verifying that upon a Sump Recirculation Actuation Test Signal, the containment sump isolation valves open and that a recirculation mode flow path via on OPERABLE shutdown cooling heat exchanger is established. 
3. Verifying that each spray pump starts automatically on a test signal.

d. At least once per 5 years by performing an air or smoke flow test through each spray header and verifying each spray nozzle is unobstructed. 
CONTAINMENT SYSTEMS

3/4.6.2 DEPRESSURIZATION AND COOLING SYSTEMS

CONTAINMENT SPRAY SYSTEM (No credit taken for iodine removal)

LIMITING CONDITION FOR OPERATION

3.6.2.1 Two independent containment spray systems shall be OPERABLE with each spray system capable of taking suction from the RWT on a Containment Spray Actuation Signal and automatically transferring suction to the containment sump on a Sump Recirculation Actuation Signal. Each spray system flow path from the containment sump shall be via an OPERABLE shutdown cooling heat exchanger.

\section{APPLICABILITY: MODES $1,2,3$ and 4}

ACTION:

a. With one containment spray system inoperable and at least (four) containment cooling fans OPERABLE, restore the inoperable spray system to OPERABLE status within 7 days or be in at least HOT STANDBY within the next 6 hours and in COLD SHUTDOWN within the following 30 hours.

b. With two containment spray systems inoperable and at least (four) containment cooling fans OPERABLE, restore at least one spray system to OPERABLE status within 72 hours or be in at least HOT STANDBY within the following 30 hours. Restore both spray systems to OPERABLE status within 7 days of initial loss or be in at least HOT STANDBY within the next 6 hours and in COLD SHUTDOWN within the following 30 hours.

c. With one containment spray system inoperable and one group of required containment cooling fans inoperable, restore either the inoperable spray system or the inoperable group of cooling fans to OPERABLE status within 72 hours or be in at least HOT STANDBY within the next 6 hours and in COLD SHUTDOWN within the following 30 hours. Restore both the inoperable spray system and the inoperable group of cooling fans to OPERABLE status within 7 days of initial loss or be in at least HOT STANDBY within the next 6 hours and in COLD SHUTDOWN within the following 30 hours.

SURVEILLANCE REQUIREMENTS

4.6.2.1 Each containment spray system shall be demonstrated OPERABLE: 
a. At least once per 31 days by verifying that each valve (manual, power operated or automatic) in the flow path is positioned to take suction from the RWT on a Containment Pressure-High-High test signal.

b. By verifying, that on recirculation flow, each pump develops a discharge pressure greater than or equal to pursuant to Specification 4.0 .5 psig when tested

c. At least once per 18 months, during shutdown, by:

1. Verifying that each automatic valve in the flow path actuates to its correct position on a test signal.

2. Verifying that upon a Sump Recirculation Actuation Test Signal, the containment sump isolation valves open and that a recirculation mode flow path via an OPERABLE shutdown cooling heat exchanger is established.

3. Verifying that each spray pump starts automatically on a test signal.

d. At least once per 5 years performing an air or smoke flow test through each spray header and verifying each spray nozzle is unobstructed. 


\section{CONTAINMENT SYSTEMS}

SPRAY ADDITIVE SYSTEM (OPTIONAL)

\section{LIMITING CONDITION FOR OPERATION}

\subsubsection{The spray additive system shall be OPERABLE with:}

a. A spray additive tank containing a volume of between and $\overline{\text { and }}$ gallons of between __ and $\ldots \%$ by weight $\mathrm{NaOH}$ solution,

b. Two spray additive eductors each capable of adding $\mathrm{NaOH}$ solution from the chemical additive tank to a containment spray system pump flow.

\section{APPLICABILITY: MODES $1,2,3$ and 4.}

\section{ACTION:}

With the spray additive system inoperable restore the system to OPERABLE status within 72 hours or be in at least HOT STANDBY within the next 6 hours; restore the spray additive system to OPERABLE status within the next 48 hours or be in COLD SHUTDOWN within the following 30 hours.

\section{SURVEILLANCE REQUIREMENTS}

4.6.2.2 The spray additive system shall be demonstrated OPERABLE:

a. At least once per 31 days by verifying that each valve (manual, power operated or automatic) in the flow path that is not locked, sealed, or otherwise secured in position, is in its correct position.

b. At least once per 6 months by:

1. Verifying the contained solution volume in the tank, and

2. Verifying the concentration of the $\mathrm{NaOH}$ solution by chemical analysis.

c. At least once per 18 months, during shutdown, by verifying that each automatic valve in the flow path actuates to its correct position on a test signal. 
d. At least once per 5 years by verifying each solution flow rate (to be determined during pre-operational tests) from the following drain connections in the spray additive system:

1. (Drain line location) _ \pm _ $\mathrm{gpm}$.

2. (Drain line location) $= \pm-\mathrm{gpm}$. 


\section{CONTAINMENT SYSTEMS}

CONTAIMMENT COOLING SYSTEM (OPTIONAL) (Credit taken for iodine removal by spray systems)

3.6.2.3 (Two) independent groups of containment cooling fans shall he OPERABLE with (two) fan systems to each group. (Equivalent to $100 \%$ cooling capacity.)

APPLICABILITY: MODES $1,2,3$ and 4.

ACTION:

a. With one group of the above required containment cooling fans inoperable and both containment spray systems OPERABLE, restore the inoperable group of cooling fans to OPERABLE status within 7 days or be in at least HOT STANDBY with in the next 6 hours and in COLD SHUTDOWN within the following 30 hours.

b. With two groups of the above required containment cooling fans inoperable, and both containment spray systems OPERABLE, restore at least one group of cooling fans to OPERABLE status within 72 hours or be in at least HOT STANDBY within the next 6 hours and in COLD SHUTDOWN within the following 30 hours. Restore both above required groups of cooling fans to OPERABLE status within 7 days of initial loss or be in at least HOT STANDBY with in the next 6 hours and in COLD SHUTDOWN within the following 30 hours.

c. With one group of the above required containment cooling fans inoperable and one containment spray system inoperable, restore the inoperable spray system to OPERABLE status within 72 hours or be in at least HOT STANDBY within the next 6 hours and in COLD SHUTDOWN within the following 30 hours. Restore the inoperable group of containment cooling fans to OPERABLE status within 7 days of initial loss or be in at least HOT STANDBY within the next 6 hours and in COLD SHUTDOWN within the following 30 hours.

SURVEILLANCE REQUIREMENTS

4.6.2.3 Each group of containment cooling fans shall be demonstrated OPERABLE:

a. At least once per 31 days by:

1. Starting each fan group from the control room and verifying that each fan group operates for at least 15 minutes. 
2. Verifying a cooling water flow rate of greater than or equal to gpm to each cooler.

b. At least once per 18 months by verifying that each fan group starts automatically on a test signal. 
CONTAINMENT SYSTEMS

CONTAINMENT COOLING SYSTEM (OPTIONAL) (No credit taken for iodine removal by spray systems)

LIMITING CONDITION FOR OPERATION

3.6.2.3 (Two) independent groups of containment cooling fans shall be OPERABLE with (two) fan systems to each group. (Equivalent to $100 \%$ cooling capacity).

APPLICABILITY: MODES $1,2,3$ and 4.

ACTION:

a. With one group of the above required containment cooling fans inoperable and both containment spray systems OPERABLE, restore the inoperable group of cooling fans to OPERABLE status within 7 days or be in at least HOT STANDBY within the next 6 hours and in COLD SHUTDOWN within the following 30 hours.

b. With two groups of the above required containment cooling fans inoperable, and both containment spray systems OPERABLE, restore at least one group of cooling fans to OPERABLE status within 72 hours or be in at least HOT STANDBY within the next 6 hours and in COLD SHUTDOWN within the following 30 hours. Restore both above required groups of cooling fans to OPERABLE status within 7 days of initial loss or be in at least HOT STANDBY within the next 6 hours and in COLD SHUTDOWN within the following 30 hours.

c. With one group of the above required containment cooling fans inoperable and one containment spray system inoperable, restore either the inoperable group of containment cooling fans or the inoperable spray system to OPERABLE status within 72 hours or be in at least HOT STANDBY within the next 6 hours and in COLD SHUTDOWN within the following 30 hours. Restore both the inoperable group of containment cooling fans and the inoperable spray system to OPERABLE status within 7 days of initial loss or be in at least HOT STANDBY within the next 6 hours and in COLD SHUTDOWN within the following 30 hours.

SURVEILLANCE REQUIREMENTS

4.6.2.3 Each group of containment cooling fans shall be demonstrated OPERABLE: 


\section{CONTAINMENT SYSTEMS}

a. At least once per 31 days by:

1. Starting each fan group from the control room and verifying that each fan group operates for at least 15 minutes.

2. Verifying a cooling water flow rate of greater than or equal to gpm to each cooler.

b. At least once per 18 months by verifying that each fan group starts automatically on a test signal. 


\section{CONTAINMENT SYSTEMS}

\section{3/4.6.3 IODINE CLEANUP SYSTEM (OPTIONAL)}

3.6.3.1 Two independent containment iodine cleanup systems shall be OPERABLE. APPLICABILITY: MODES $1,2,3$ and 4.

ACTION:

With one iodine cleanup system inoperable, restore the inoperable system to OPERABLE status within 7 days or be in at least HOT STANDBY within the next 6 hours and in COLD SHUTDOWN within the following 30 hours.

\section{SURVEILLANCE REQUIREMENTS}

4.6.3.1 Each iodine cleanup system shall be demonstrated OPERABLE:

a. At least once per 31 days on a STAGGERED TEST BASIS by initiating, from the control room, flow through the HEPA filters and charcoal adsorbers and verifying that the system operates for at least 10 hours with the heaters on.

b. At least once per 18 months or (1) after any structural maintenance on the HEPA filter or charcoal adsorber housings, or (2) following painting, fire or chemical release in any ventilation zone communicating with the system by:

1. Verifying that the cleanup system satisfies the in-place testing acceptance criteria and uses the test procedures of Regulatory Positions C.5.a, C.5.C and C.5.d of Regulatory Guide 1.52, Revision 2, March 1978, and the system flow rate is $\mathrm{cfm} \pm 10 \%$.

2. Verifying within 31 days after removal that a laboratory analysis of a representative carbon sample obtained in accordance with Regulatory Position C.6.b of Regulatory Guide 1.52, Revision 2, March 1978, meets the laboratory testing criteria of Regulatory Position C.6. a of Regulatory Guide 1.52, Revision 2, March 1978.

3. Verifying a system flow rate of $\mathrm{cfm}+10 \%$ during system operation when tested in accordance with ANNSI N510-1975. 


\section{CONTAINMENT SYSTEMS}

c. After every 720 hours of charcoal adsorber operation by verifying within 31 days after removal that a laboratory analysis of a representative carbon sample obtained in accordance with Regulatory Position C.6.b of Regulatory Guide 1.52, Revision 2, March 1978, meets the laboratory testing criteria of Regulatory Position C.6.a of Regulatory Guide 1.52, Revision 2, March 1978.

d. At least once per 18 months by:

1. Verifying that the pressure drop across the combined HEPA filters and charcoal adsorber banks is less than (6) inches Water Gauge while operating the system at a flow rate of cfm $\pm 10 \%$.

2. Verifying that the system starts on either a Safety Injection Actuation Test Signal or on a Containment Pressure - High Test Signal.

3. Verifying that the filter cooling bypass valves can be opened by operator action.

4. Verifying that the heaters dissipate when tested in accordance with ANSI N510-1975. kw

e. After each complete or partial replacement of a HEPA filter bank by verifying that the HEPA filter banks remove greater than or equal to $(99.95 \%)^{*}$ of the DOP when they are tested in-place in accordance with ANSI N510-1975 while operating the system at a flow rate of $\mathrm{cfm} \pm 10 \%$.

f. After each complete or partial replacement of a charcoal adsorber bank by verifying that the charcoal adsorbers remove greater than or equal to $99.95 \%$ of a halogenated hydrocarbon refrigerant test gas when they are tested in-place in accordance with ANSI N510-1975 while operating the system at a flow rate of _ cfm $\pm 10 \%$.

*99.95\% applicable when a filter efficiency of $99 \%$ is assumed in the safety analyses; $99 \%$ when a filter efficiency of $99 \%$ is assumed. 
CONTAINMENT SYSTEMS

$3 / 4.6 .4$ CONTAINMENT ISOLATION VALVES

LIMITING CONDITION FOR OPERATION

3.6.4 The containment isolation valves specified in Table 3.6-2 shall be OPERABLE with isolation times as shown in Table 3.6-2.

APPLICABILITY: MODES $1,2,3$ and 4.

ACTION:

With one or more of the isolation valve(s) specified in Table 3.6-2 inoperable, maintain are least one isolation valve OPERABLE in each affected penetration that is open and either:

a. Restore the inoperable valve(s) to OPERABLE status within 4 hours, or

b. Isolate each affected penetration within 4 hours by use of at least one deactivated automatic valve secured in the isolation position, or

c. Isolate each affected penetration within 4 hours by use of at least one closed manual valve or blind flange; or

d. Be in at least HOT STANDBY within the next 6 hours and in COLD SHUTDOWN within the following 30 hours.

4.6.4.1 The isolation valves specified in Table 3.6-2 shall be demonstrated OPERABLE prior to returning the valve to service after maintenance, repair or replacement work is performed on the valve or its associated actuator, control or power circuit by performance of a cycling test and verification of isolation time. 
4.6.4.2 Each isolation valve specified in Table 3.6-2 shall be demonstrated OPERABLE during the COLD SHUTDOWN or REFUELING MODE at least once per 18 months by:

a. Verifying that on a containment isolation test signal, each isolation valve actuates to its isolation position.

b. Verifying that on a Containment Radiation-High test signal, each containment purge valve actuates to its isolation position.

4.6.4.3 The isolation time of each power operated or automatic valve of Table . 3.6-2 shall be determined to be within its limit when tested pursuant to Specification 4.0 .5 .

4.6.4.4 Each containment purge isolation valve shall be demonstrated OPERABLE within 24 hours after each closing of the valve, except when the valve is being used for multiple cyclings, then at least once per 72 hours, by verifying that when the measured leakage rate is added to the leakage rates determined pursuant to Specification 4.6.1.2d. for all other Type B and C penetrations, the combined leakage rate is less than or equal to $0.60 \mathrm{~L}_{a^{*}}$. 
TABLE 3.6-2

CONTAINMENT ISOLATION VALVES

VALVE NUMBER

FUNCTION

A. CONTAINMENT ISOLATION

1.

2.

B. CONTAINMENT PURGE

1.

2.

c. MANUAL

1.

2.

D. OTHER

1.

2.
ISOLATION TIME

$\leq()$ seconds

D
on
1
I

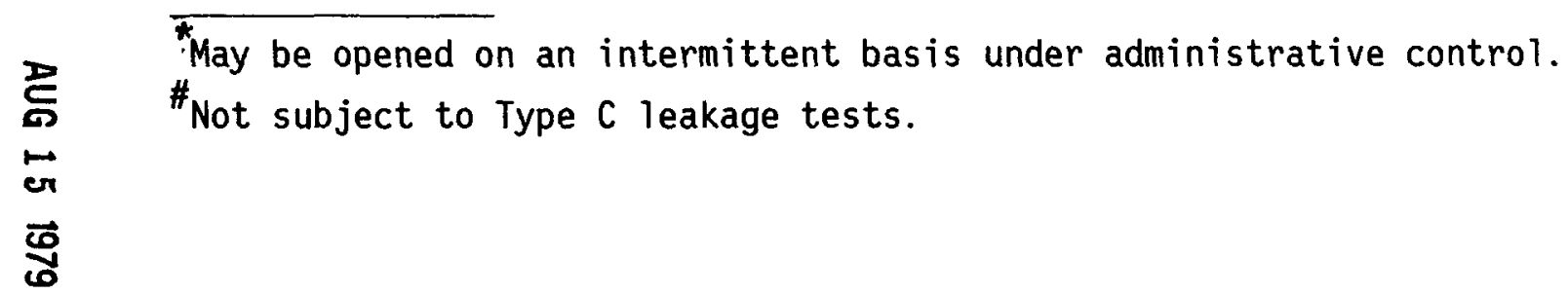


CONTAINMENT SYSTEMS

3/4.6.5 COMBUSTIBLE GAS CONTROL

HYDROGEN ANALYZERS

LIMITING CONDITION FOR OPERATION

3.6.5.1 Two independent containment hydrogen analyzers shall be OPERABLE. APPLICABILITY: MODES 1 and 2.

ACTION:

With one hydrogen analyzer inoperable, restore the inoperable analyzer to OPERABLE status within 30 days or be in at least HOT STANDBY within the next 6 hours.

\section{SURVEILLANCE REQUIREMENTS}

4.6.5.1 Each hydrogen analyzer shall be demonstrated OPERABLE at least once per 92 days on a STAGGERED TEST BASIS by performing a CHANNEL CALIBRATION using sample gases containing:

a. One volume percent hydrogen, balance nitrogen, and

b. Four volume percent hydrogen, balance nitrogen. 
CONTAINMENT SYSTEMS

ELECTRIC HYDROGEN RECOMBINERS - W

LIMITING CONDITION FOR OPEPATION

3.6.5.2 Two independent containment hydrogen recombiner systems shall be OPERABLE.

APPLICABILITY: MODES 1 and 2.

ACTION:

With one hydrogen recombiner system inoperable, restore the inoperable system to OPERABLE status within 30 days or be in at least HOT STANDBY within the next 6 hours.

\section{SURVEILLANCE REOUIREMENTS}

4.6.5.2 Each hydrogen recombiner system shall be demonstrated OPERABLE:

a. At least once per 6 months by verifying during a recombiner system functional test that the minimum heater sheath temperature increases to greater than or equal to $700^{\circ} \mathrm{F}$ within 90 minutes and is maintained for at least 2 hours.

b. At least once per 18 months by:

1. Performing a CHANNEL CALIBRATION of all recombiner instrumentation and control circuits.

2. Verifying through a visual examination that there is no evidence of abnormal conditions within the recombiners (i.e., loose wiring or structural connections, deposits of foreign materials, etc.).

3. Verifying during a recombiner system functional test that the heater sheath temperature increases to greater than or equal to $1200^{\circ} \mathrm{F}$ within 5 hours and is maintained for at least 4 hours.

4. Verifying the integrity of the heater electrical circuits by performing a continuity and resistance to ground test following the above required functional test. The resistance to ground for any heater phase shall be greater than or equal to 10,000 ohms. 
HYDROGEN PURGE CLEANUP SYSTEM (If less than two hydrogen recombiners available) LIMITING CONDITION FOR OPERATION

3.6.5.3 A containment hydrogen purge cleanup system shall be OPERABLE and capable of being powered from a minimum of one OPERABLE emergency bus.

APPLICABILITY: MODES 1 and 2.

ACTION:

With the containment hydrogen purge cleanup system inoperable, restore the hydrogen purge cleanup system to OPERABLE status within 30 days or be at least in HOT STANDBY within the next 6 hours.

\section{SURVEILLANCE REQUIREMENTS}

4.6.5.3 The hydrogen purge cleanup system shall be demonstrated OPERABLE:

a. At least once per 31 days by initiating, from the control room, flow through the HEPA filters and charcoal adsorbers and verifying that the system operates for at least 10 hours with the heaters on.

b. At least once per 18 months or (1) after any structural maintenance on the HEPA filter or charcoal adsorber housings, or (2) following painting, fire or chemical release in any ventilation zone communicating with the system by:

1. Verifying that the cleanup system satisfies the in-place testing acceptance criteria and uses the test procedures of Regulatory Positions C.5.a, C.5.C and C.5.d of Regulatory Guide 1.52, Revision 2, March 1978, and the system flow rate is $\mathrm{cfm} \pm 10 \%$.

2. Verifying within 31 days after removal that a laboratory analysis of a representative carbon sample obtained in accordance with Regulatory Position C.6.b of Regulatory Guide 1.52, Revision 2, March 1978, meets the laboratory testing criteria of Regulatory Position C.6. a of Regulatory Guide 1.52, Revision 2, March 1978.

3. Verifying a system flow rate of _cfm $+10 \%$ during system. operation when tested in accordance with A NSI N510-1975. 
c. After every 720 hours of charcoal adsorber operation by verifying within 31 days after removal that a laboratory analys is of a representative carbon sample obtained in accordance with Regulatory Position C.6.b of Regulatory Guide 1.52, Revision 2, March 1978, meets the laboratory testing criteria of Regulatory Position C.6. a of Regulatory Guide 1.52, Revision 2, March 1978.

d. At least once per 18 months by:

1. Verifying that the pressure drop across the combined HEPA filters and charcoal adsorber banks is less than (6) inches Water Gauge while operating the system at a flow rate of $\mathrm{cfm} \pm 10 \%$.

2. Verifying that the filter cooling bypass valves can be manually opened.

3. Verifying that the heaters dissipate tested in accordance with ANSI N510-1975.

$\pm$ kw when

e. After each complete or partial replacement of a HEPA filter bank by verifying that the HEPA filter banks remove greater than or equal to (99.95)\%* of the DOP when they are tested in-place in accordance with ANSI N510-1975 while operating the system at a flow rate of $\mathrm{cfm} \pm 10 \%$.

f. After each complete or partial replacement of a charcoal adsorber bank by verifying that the charcoal adsorbers remove greater than or equal to $99.95 \%$ of a halogenated hydrocarbon refrigerant test gas when they are tested in-place in accordance with ANSI N510-1975 while operating the system at a flow rate of $\mathrm{cfm} \pm 10 \%$.

ॠ99.95\% applicable when a filter efficiency of $99 \%$ is assumed in the safety analyses; $99 \%$ when a filter efficiency of $90 \%$ is assumed. 


\section{CONTAINMENT SYSTEMS}

HYDROGEN MIXING SYSTEM (OPTIONAL)

3.6.5.4 Two independent hydrogen mixing systems shall be OPERABLE.

APPLICABILITY: MODES 1 and 2.

ACTION:

With one hydrogen mixing system inoperable, restore the inoperable system to OPERABLE status within 30 days or be in at least HOT STANDBY within the next 6 hours.

\section{SURVEILLANCE REQUIREMENTS}

4.6.5.4 Each hydrogen mixing system shall be demonstrated OPERABLE:

a. At least once per 92 days on a STAGGERED TEST BASIS by starting each system from the control room, and verifying that the system operates for at least 15 minutes.

b. At least once per 18 months by verifying a system flow rate of at least cfm. 
3/4.6.6 PENETRATION ROOM EXHAUST AIR CLEANUP SYSTEM (OPTIONAL)

3.6.6 Two independent containment penetration room exhaust air cleanup systems shall be OPERABLE.

APPLICABILITY: MODES $1,2,3$ and 4.

\section{ACTION:}

With one containment penetration room exhaust air cleanup system inoperable, restore the inoperable system to OPERABLE status within 7 days or be in at least HOT STANDBY within the next 6 hours and in COLD SHUTDOWN within the following 30 hours.

4.6.6 Each containment penetration room exhaust air cleanup system shall be demonstrated OPERABLE:

a. At least once per 31 days on a STAGGERED TEST BASIS by initiating, from the control room, flow through the HEPA filters and charcoal adsorbers and verifying that the system operates for at least 10 hours with the heaters on.

b. At least once per 18 months or (1) after any structural maintenance on the HEPA filter or charcoal adsorber housings, or (2) following painting, fire or chemical release in any ventilation zone communicating with the system by:

1. Verifying that with the system operating at a flow rate of cfm $+10 \%$ and exhausting through the HEPA filters and charcoaT adsorbers, the total bypass flow of the system to the facility vent, including leakage through the system diverting valves, is less than or equal to $1 \%$ when the system is tested by admitting cold DOP at the system intake. (For systems with diverting valves.)

2. Verifying that the cleanup system satisfies the in-place testing acceptance criteria and uses the test procedures of Regulatory Positions C.5.a, C.5.C and C.5.d of Regulatory Guide 1.52, Revision 2, March 1978, and the system flow rate is cfm $\pm 10 \%$. 
3. Verifying within 31 days after removal that a laboratory analys is of a representative carbon sample obtained in accordance with Regulatory Position C.6.b of Regulatory Guide 1.52, Revision 2, March 1978, meets the laboratory testing criteria of Regulatory Position C.6. a of Regulatory Guide 1.52, Revision 2, March 1978.

4. Verifying a system flow rate of _ cfm $+10 \%$ during system operation when tested in accordance with ÂNSI N510-1975.

c. After every 720 hours of charcoal adsorber operation by verifying within 31 days after removal that a laboratory analysis of a representative carbon sample obtained in accordance with Regulatory Position C.6.b of Regulatory Guide 1.52, Revision 2, March 1978, meets the laboratory testing criteria of Regulatory Position C.6.a of Regulatory Guide 1.52, Revision 2, March 1978.

d. At least once per 18 months by:

1. Verifying that the pressure drop across the combined HEPA filters and charcoal adsorber banks is less than (6) inches Water Gauge while operating the system at a flow rate of $\mathrm{cfm} \pm 10 \%$.

2. Verifying that the system starts on a Safety Injection Actuation Test Signa?.

3. Verifying that the filter cooling bypass valves can be manually opened.

4. Verifying that the heaters dissipate $\pm \ldots$ Ww when tested in accordance with ANSI N510-1975.

e. After each complete or partial replacement of a HEPA filter bank by verifying that the HEPA filter banks remove greater than or equal to (99.95)\%* of the DOP when they are tested in-place in accordance with ANSI N510-1975 while operating the system at a flow rate of $\mathrm{cfm} \pm 10 \%$.

f. After each complete or partial replacement of a charcoal adsorber bank by verifying that the charcoal adsorbers remove greater than or equal to $99.95 \%$ of a halogenated hydrocarbon refrigerant test gas when they are tested in-place in accordance with ANSI N510-1975 while operating the system at a flow rate of $\mathrm{cfm} \pm 10 \%$.

ॠ99.95\% applicable when a filter efficiency of $99 \%$ is assumed in the safety analyses; $99 \%$ when a filter efficiency of $90 \%$ is assumed. 
CONTAINMENT SYSTEMS

3/4.6.7 VACLIUM RELIEF VALVES (OPTIONAL)

LIMITING CONDITION FOR OPERATION

3.6.7 The primary containment to atmosphere vacuum relief valves shall be OPERABLE with an actuation set point of less than or equal to psid.

APPLICABILITY: MODES $1,2,3$ and 4.

ACTION:

With one primary containment to atmosphere vacuum relief valve inoperable, restore the valve to OPERABLE status within 4 hours or be in at least HOT STANDBY within the next 6 hours and in COLN SHUTDOWN within the following 30 hours.

4.6.7 No additional Surveillance Requirements other than those required by Specification 4.0 .5 . 
CONTAINMENT SYSTEMS

3/4.6.8 SECONDARY CONTAINMENT

SHIELD BUILDING AIR CLEANUP SYSTEM

LIMITING CONDITION FOR OPERATION

3.6.8.1 Two independent shield building air cleanup systems shall be OPERABLE.

APPLICABILITY: MODES 1,2, 3 and 4.

\section{ACTION:}

With one shield building air cleanup system inoperable, restore the inoperable system to OPERABLE status within 7 days or be in at least HOT STANDBY within the next 6 hours and in COLD SHUTDOWN within the following 30 hours.

4.6.8.1 Each shield building air cleanup system shall be demonstrated OPERABLE:

a. At least once per 31 days on a STAGGERED TEST BASIS by initiating, from the control room, flow through the HEPA filters and charcoai adsorbers and verifying that the system operates for at least 10 hours with the heaters on.

b. At least once per 18 months or (1) after any structural maintenance on the HEPA filter or charcoal adsorber housings, or (2) following painting, fire or chemical release in any ventilation zone communicating with the system by:

1. Verifying that with the system operating at a flow rate of $\mathrm{cfm}+10 \%$ and exhausting through the HEPA filters and charcoaT adsorbers, the total bypass flow of the system to the facility vent, including leakage through the system diverting valves, is less than or equal to $1 \%$ when the system is tested by admitting cold DOP at the system intake. (For systems with diverting valves.) 


\section{CONTAINMENT SYSTEMS}

2. Verifying that the cleanup system satisfies the in-place testing acceptance criteria and uses the test procedures of Regulatory Positions C.5.a, C.5.C and C.5.d of Regulatory Guide 1.52, Revision 2, March 1978, and the system flow rate is $\mathrm{cfm} \pm 10 \%$.

3. Verifying within 31 days after removal that a laboratory analysis of a representative carbon sample obtained in accordance with Regulatory Position C.6.b of Regulatory Guide 1.52, Revision 2, March 1978, meets the laboratory testing criteria of Regulatory Position C.6.a of Regulatory Guide 1.52, Revision 2, March 1978.

4. Verifying a system flow rate of _ cfm $+10 \%$ during system operation when tested in accordance with ANNSI N510-1975.

c. After every 720 hours of charcoal adsorber operation by verifying within 31 days after removal that a laboratory analysis of a representative carbon sample obtained in accordance with Regulatory Position C.6.b of Regulatory Guide 1.52, Revision 2, March 1978, meets the laboratory testing criteria of Regulatory Position C.6.a of Regulatory Guide 1.52, Revision 2, March 1978.

d. At least once per 18 months by:

1. Verifying that the pressure drop across the combined HEPA filters and charcoal adsorber banks is less than (6) inches Water Gauge while operating the system at a flow rate of $\mathrm{cfm} \pm 10 \%$.

2. Verifying that the system starts on a Shield Building Filtration Actuation Test Signal.

3. Verifying that the filter cooling bypass valves can be manually opened.

4. Verifying that each system produces a negative pressure of greater than or equal to (0.25) inches W.G. in the annulus within (1) minute after a start signal.

5. Verifying that the heaters dissipate tested in accordance with ANSI N510-1975.

$\pm$ kw when 
e. After each complete or partial replacement of a HEPA filter bank by verifying that the HEPA filter banks remove greater than or equal to $(99.95) \% *$ of the DOP when they are tested in-place in accordance with ANSI N510-1975 while operating the system at a flow rate of $\mathrm{cfm} \pm 10 \%$.

f. After each complete or partial replacement of a charcoal adsorber bank by verifying that the charcoal adsorbers remove greater than or equal to $99.95 \%$ of a halogenated hydrocarbon refrigerant test gas when they are tested in-place in accordance with ANSI N510-1975 while operating the system at a flow rate of $\mathrm{cfm} \pm 10 \%$.

₹99.95\% applicable when a filter efficiency of $99 \%$ is assumed in the safety analyses; $99 \%$ when a filter efficiency of $90 \%$ is as sumed. 
CONTAINMENT SYSTEMS

SHIELD BUILDING INTEGRITY

LIMITING CONDITION FOR OPERATION

3.6.8.2 SHIELD BUILDING INTEGRITY shall be maintained.

APPL ICABILITY: MODES $1,2,3$ and 4.

ACTION:

Wi thout SHIELD BUILDING INTEGRITY, restore SHIELD BUILDING INTEGRITY within 24 hours or be in at least HOT STANDBY within the next 6 hours and in COLD

SHUTDOWN within the following 30 hours.

4.6.8.2 SHIELD BUILDING INTEGRITY shall be demonstrated at least once per 31 days by verifying that each door in each access opening is closed except when the access opening is being used for normal transit entry and exit, then at least one door shall be closed. 
3.6.8.3 The structural integrity of the shield building shall be maintained at a level consistent with the acceptance criteria in Specification 4.6.8.3. APPLICABILITY: MODES $1,2,3$ and 4.

\section{ACTION}

With the structural integrity of the shield building not conforming to the above requirements, restore the structural integrity to within the limits within 24 hours or be in at least HOT STANDBY within the next 6 hours and in COLD SHUTDOWN within the following 30 hours.

4.6.8.3 The structural integrity of the shield building shall be determined during the shutdown for each Type A containment leakage rate test (reference Specification 4.6 .1 .2 ) by a visual inspection of the exposed accessible interior and exterior surfaces of the shield building and verifying no apparent changes in appearance of the concrete surfaces or other abnormal degradation. Any abnormal degradation of the shield building detected during the above required inspections shall be reported to the Commission pursuant to Specification 6.9.1. 
3/4.7 PLANT SYSTEMS

3.4.7.1 TURBINE CYCLE

SAFETY VALVES

LIMITING CONDITION FOR OPERATION

3.7.1.1 All main steam line code safety valves shall be OPERABLE with lift settings as specified in Table 3.7-1.

APPLICABILITY: MODES 1,2 and 3.

\section{ACTION:}

a. With both reactor coolant loops and associated steam generators in operation and with one or more main steam line code safety valves inoperable, operation in MODES 1,2 and 3 may proceed provided, that within 4 hours, either the inoperable valve is restored to OPERABLE status or the Power Level-High trip setpoint is reduced per Table 3.7-2; otherwise, be in at least HOT STANDBY within the next 6 hours and in COLD SHUTDOWN within the following 30 hours.

b. With one reactor coolant loop and associated steam generator in operation and with one or more main steam line code safety valves associated with the operating steam generator inoperable, operation in MODES 1,2 and 3 may proceed provided:

1. That at least (2) main steam line code safety valves on the nonoperating steam generator are OPERABLE, and

2. That within 4 hours, either the inoperable valve is restored to OPERABLE status or the Power Level-High trip setpoint is reduced per Table 3.7-3; otherwise, be in at least HOT STANDBY within the next 6 hours and in COLD SHUTDOWN within the following 30 hours.

c. The provisions of Specification 3.0.4 are not applicable.

4.7.1.1 No additional Surveillance Requirements other than those required by Specification 4.0 .5 . 
TABLE $3.7-1$

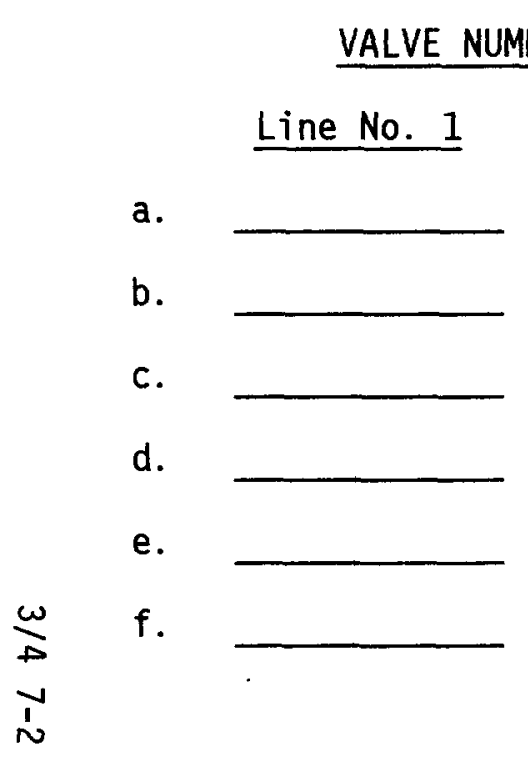

STEAM LINE SAFETY VALVES PER LOOP

LIFT SETTING $( \pm 1 \%)^{*}$

ORIFICE SIZE

Line No. 2

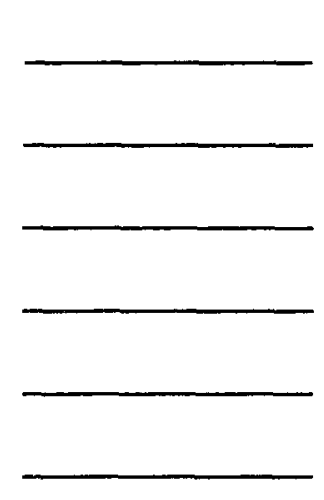

psia

psia

psia

psia

psia

psia

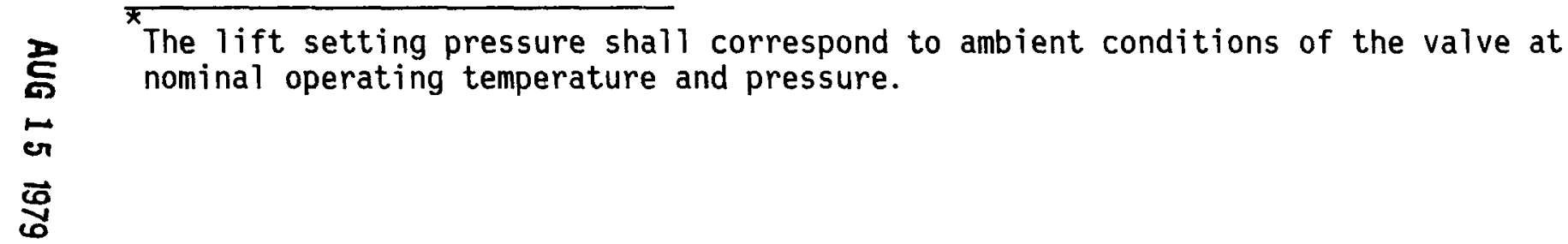

The lift setting pressure shall correspond to ambient conditions of the valve at nominal operating temperature and pressure. 
TABLE 3.7-2

MAXIMUM ALLOWABLE LINIAR POWER LEVEL-HIGH TRIP SETPOINT WITH INOPERABLE STEAM LINE SAFETY VALVES DURING OPERATION WITH BOTH STEAM GENERATORS

Maximum Number of Inoperable Safety Valves on Any Operating Steam Generator

1

2

3
Maximum Allowable Liniar Power

Leve 1-High Trip Setpoint

(Percent of RATED THERMAL POWER)

$(99.5)$

(74)

(48.6)

$\frac{\omega}{\not}$
$\stackrel{\omega}{\omega}$

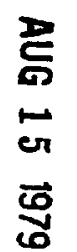


TABLE 3.7-3

MAXIMUM ALLOWABLE LINIAR POWER LEVEL-HIGH TRIP SETPOINT WITH INOPERABLE STEAM LINE SAFETY VALVES DURING OPERATION WITH ONE STEAM GENERATOR

Maximum Number of Inoperable Safety Valves on The Operating Steam Generator

1

2

3
Maximum Allowable Liniar Power Leve]-High Trip Setpoint

(Percent of RATED THERMAL POWER)

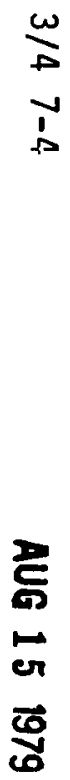


PLANT SYSTEMS

AUXILIARY FEEDWATER SYSTEM

LIMITING CONDITION FOR OPERATION

3.7.1.2 At least three independent steam generator auxiliary feedwater pumps and associated flow paths shall be OPERABLE with:

a. Two feedwater pumps, each capable of being powered from separate OPERABLE emergency busses, and

b. One feedwater pump capable of being powered from an OPERABLE steam supply system.

APPLICABILITY: MODES 1, 2 and 3.

ACTION:

With one auxiliary feedwater pump inoperable, restore at least three auxiliary feedwater pumps (two capable of being powered from separate emergency busses and one capable of being powered by an OPERABLE steam suppiy system) to OPERABLE status within 72 hours or be in at least HOT STANDBY within the next 6 hours and in HOT SHUTDOWN within the following 6 hours.

SURVEILLANCE REQUIREMENTS

4.7.1.2 Each auxiliary feedwater pump shall be demonstrated OPERABLE:

a. At least once per 31 days by:

1. Verifying that each motor driven pump develops a discharge pressure of greater than or equal to _ psig at a flow of greater than or equal to $\mathrm{gpm}$.

2. Verifying that the turbine driven pump develops a discharge pressure of greater than or equal to psig at a flow of greater than or equal to steam supply pressure is greater than psig. The gpm when the secondary provisions of Specification 4.0.4 are not applicable for entry into MODE 3 .

3. Verifying that each non-automatic valve in the flow path that is not locked, sealed, or otherwise secured in position, is in its correct position. 


\section{PLANT SYSTEMS}

\section{SURVEILLANCE REQUIREMENTS (Continued)}

b. At least once per 18 months during shutdown by:

1. Verifying that each automatic valve in the flow path actuates to its correct position on a test signal.

2. Verifying that each pump starts automatically upon receipt of a test signal. 
PLANT SYSTEMS

CONDENSATE STORAGE TANK

LIMITING CONDITION FOR OPERATION

3.7.1.3 The condensate storage tank (CST) shall be OPERABLE with a minimum contained water volume of $(160,000)$ gallons.

APPLICABILITY: MODES 1, 2 and 3.

ACTION:

With the condensate storage tank inoperable, within 4 hours either:

a. Restore the CST to OPERABLE status or be in at least HOT STANDBY within the next 6 hours and in HOT SHUTDOWN within the following 6 hours, or

b. Demonstrate the OPERABILITY of the (alternate water source) as a backup supply to the auxiliary feedwater pumps and restore the condensate storage tank to OPERABLE status within 7 days or be in at least HOT STANDBY within the next 6 hours and in HOT SHUTDOWN within the following 6 hours.

\section{SURVEILLANCE REQUIREMENTS}

4.7.1.3.1 The condensate storage tank shal1 be demonstrated OPERABLE at least once per 12 hours by verifying the contained water volume is within its limits when the tank is the supply source for the auxiliary feedwater pumps.

4.7.1.3.2 The (alternate water source) shall be demonstrated OPERABLE at least once per 12 hours by (method dependent upon alternate source) whenever the (alternate water source) is the supply source for the auxiliary feedwater pumps. 
PLANT SYSTEMS

ACT IVITY

LIMITING CONDITION FOR OPERATION

3.7.1.4 The specific activity of the secondary coolant system shall be less than or equal to 0.10 microcuries/gram DOSE EQUIVALENT I-131.

APPLICABILITY: MODES 1, 2, 3 and 4.

\section{ACTION:}

With the specific activity of the secondary coolant system greater than 0.10 microcuries/gram DOSE EQUIVALENT I-131, be in at least HOT STANDBY within 6 hours and in COLD SHUTDOWN within the following 30 hours.

4.7.1.4 The specific activity of the secondary coolant system shall be determined to be within the limit by performance of the sampling and analys is program of Table 4.7-1. 


\section{TABLE 4.7-1}

SECONDARY COOLANT SYSTEM SPECIFIC ACTIVITY SAMPLE AND ANALYSIS PROGRAM

TYPE OF MEASUREMENT

AND ANALYSIS

1. Gross Activity Determination

2. Isotopic Analys is for DOSE EQUIVALENT I-131 Concentration
SAMPLE AND ANALYSIS FREQUENCY

At least once per 72 hours

a) 1 per 31 days, whenever the gross activity determination indicates iodine concentrations greater than $10 \%$ of the allowable limit.

b) 1 per 6 months, whenever the gross activity determination indicates iodine concentrations below $10 \%$ of the allowable limit. 


\section{PLANT SYSTEMS}

MAIN STEAM LINE ISOLATION VALVES

3.7.1.5 Each main steam line isolation valve shall be OPERABLE. APPLICABILITY: MODES 1,2 and 3. ACTION:

MODE 1 - With one main steam line isolation valve inoperable, POWER OPERATION may continue provided the inoperable valve is either restored to OPERABLE status or closed within 4 hours; otherwise, be in at least HOT STANDBY within the next 6 hours and in HOT SHUTDOWN within the following 6 hours.

MODES 2 - With one main steam line isolation valve inoperable, and 3 subseqent operation in MODES 1,2 or 3 may proceed provided:

a. The isolation valve is maintained closed.

b. The provisions of Specification 3.0.4 are not applicable.

Otherwise, be in at least HOT STANDBY with the next 6 hours and in HOT SHUTDOWN within the following 6 hours.

4.7.1.5 Each main steam line isolation valve shall be demonstrated OPERABLE by verifying full closure within $(3.0)$ seconds when tested pursuant to Specification 4.0.5. 


\section{PLANT SYSTEMS}

\section{3/4.7.2 STEAM GENERATOR PRESSURE/TEMPERATURE LIMITATION}

3.7.2 The temperatures of both the primary and secondary coolants in the steam generators shall be greater than $(90)^{\circ} \mathrm{F}$ when the pressure of either coolant in the steam generator is greater than (275) psig.

\section{APPLICABILITY: At all times.}

ACTION:

With the requirements of the above specification not satisfied:

a. Reduce the steam generator pressure of the applicable side to less than or equal to (275) psig within 30 minutes, and

b. Perform an engineering evaluation to determine the effect of the overpressurization on the structural integrity of the steam generator. Determine that the steam generator remains acceptable for continued operation prior to increasing its temperatures above $200^{\circ} \mathrm{F}$.

\section{SURVEILLANCE REQUIREMENTS}

4.7.2 The pressure in each side of the steam generators shall be determined to be less than 275 psig at least once per hour when the temperature of either the primary or secondary coolant is less than $90^{\circ} \mathrm{F}$. 


\section{PLANT SYSTEMS}

\section{3/4.7.3 COMPONENT COOLING WATER SYSTEM}

\section{LIMITING CONDITION FOR OPERATION}

3.7.3 At least two independent component cooling water loops shall be OPERABLE.

APPLICABILITY: MODES $1,2,3$ and 4.

ACTION:

With only one component cooling water loop OPERABLE, restore at least two loops to OPERABLE status within 72 hours or be in at least HOT STANDBY within the next 6 hours and in COLD SHUTDOWN within the following 30 hours.

4.7.3 At least two component cooling water loops shall be demonstrated OPERABLE:

a. At least once per 31 days by verifying that each valve (manual, power operated or automatic) servicing safety related equipment that is not locked, sealed, or otherwise secured in position, is in its correct position.

b. At least once per 18 months during shutdown, by verifying that each automatic valve servicing safety related equipment actuates to its correct position on a test signal. 


\section{PLANT SYSTEMS}

3/4.7.4 SERVICE WATER SYSTEM

LIMITING CONDITION FOR OPERATION

3.7.4 At least two independent service water loops shall be OPERABLE.

APPLICABILITY: MODES $1,2,3$ and 4.

ACTION:

With only one service water loop OPERABLE, restore at least two loops to OPERABLE status within 72 hours or be in at least HOT STANDBY within the next 6 hours and in COLD SHUTDOWN within the following 30 hours.

4.7.4 At least two service water loops shall be demonstrated OPERABLE:

a. At least once per 31 days by verifying that each valve (manual, power operated or automatic) servicing safety related equipment that is not locked, sealed or otherwise secured in position, is in its correct position.

b. At least once per 18 months during shutdown, by verifying that each automatic valve servicing safety related equipment actuates to its correct position on a test signai. 
PLANT SYSTEMS

3/4.7.5 ULTIMATE HEAT SINK (OPTIONAL)

LIMITING CONDITION FOR OPERATION

3.7.5 The ultimate heat sink shall be OPERABLE with:

a. A minimum water level at or above elevation ( ) Mean Sea Level, USGS datum, and

b. An average water temperature of less than or equal to ()$^{\circ} \mathrm{F}$.

APPLICABILITY: MODES $1,2,3$, and 4 .

ACTION:

With the requirements of the above specification not satisfied, be in at least HOT STANDBY within 6 hours and in COLD SHUTDOWN within the following 30 hours.

4.7.5 The ultimate heat sink shall be determined OPERABLE at least once per 24 hours by verifying the average water temperature and water level to be within their limits. 
PLANTS SYSTEMS

3/4.7.6 FLOOD PROTECTION (OPTIONAL*)

LIMITING CONDITION FOR OPERATION

3.7.6 Flood protection shall be provided for all safety related systems, components and structures when the water level of the

ultimate heat sink) exceeds Mean Sea Level USGS datum, at

\section{APPLICABILITY: At all times.}

\section{ACTION:}

With the water level at datum: above elevation Mean Sea Leve1 USGS

a. (Be in at least HOT STANDBY within 6 hours and in at least COLD SHUTDOWN within the following 30 hours) and

b. Initiate and complete within protection measures: hours, the following flood

1. (Plant dependent)

2. (Plant dependent)

\section{SURVEILLANCE REQUIREMENTS}

4.7.6 The water level at shall be determined to be within the limits by:

a. Measurement at least once per 24 hours when the water level is below elevation Mean Sea Level USGS datum, and

b. Measurement at least once per 2 hours when the water level is equal to or above elevation Mean Sea Level USGS datum.

\footnotetext{
"This specification not required if the facility design has adequate passive flood control protection features sufficient to accommodate the Design Basis Flood identified in Regulatory Guide 1.59, August 1973.
} 
PLANT SYSTEMS

3/4.7.7 CONTROL ROOM EMERGENCY AIR CLEANUP SYSTEM

LIMITING CONDITION FOR OPERATION

3.7.7 Two independent control room emergency air cleanup systems shall be OPERABLE.

APPLICABILITY: MODES 1, 2, 3 and 4.

ACTION:

With one control room emergency air cleanup system inoperable, restore the inoperable system to OPERABLE status within 7 days or be in at least HOT STANDBY within the next 6 hours and in COLD SHUTDOWN with in the following 30 hours.

SURVEILLANCE REQUIREMENTS

4.7.7 Each control room emergency air cleanup system shall be demonstrated OPERABLE:

a. At least once per 12 hours by verifying that the control room air temperature is less than or equal to $(120)^{\circ} \mathrm{F}$.

b. At least once per 31 days on a STAGGERED TEST BASIS by initating, from the control room, flow through the HEPA filters and charcoal adsorbers and verifying that the system operates for at least 10 hours with the heaters on.

c. At least once per 18 months or (1) after any structural maintenance on the HEPA filter or charcoal adsorber housings, or (2) following painting, fire or chemical release in any ventilation zone communicating with the system by:

1. Verifying that with the system operating at a flow rate of cfm $+10 \%$ and exhausting through the HEPA filters and charcoa? adsorbers, the total bypass flow of the system to the facility vent, including leakage through the system diverting valves, is less than or equal to $1 \%$ when the system is tested by admitting cold DOP at the system intake. (For systems with diverting valves.) 
PLANT SYSTEMS

SURVEILLANCE REQUIREMENTS (Continued)

2. Verifying that the cleanup system satisfies the in-place testing acceptance criteria and uses the test procedures of Regulatory Positions C.5.a, C.5.c and C.5.d of Regulatory Guide 1.52, Revision 2, March 1978, and the system flow rate is $\mathrm{cfm} \pm 10 \%$.

3. Verifying within 31 days after removal that a laboratory analys is of a representative carbon sample obtained in accordance with Regulatory Position C.6.b of Regulatory Guide 1.52, Revision 2, March 1978, meets the laboratory testing criteria of Regulatory Position C.6. a of Regulatory Guide 1.52, Revision 2, March 1978.

4. Verifying a system flow rate of $\mathrm{cfm}+10 \%$ during system operation when tested in accordance with AN̄SI N510-1975.

d. After every 720 hours of charcoal adsorber operation by verifying within 31 days after removal that a laboratory analysis of a representative carbon sample obtained in accordance with Regulatory Position C.6.b of Regulatory Guide 1.52, Revision 2, March 1978, meets the laboratory testing criteria of Regulatory Position C.6.a of Regulatory Guide 1.52, Revision 2, March 1978.

e. At least once per 18 months by:

1. Verifying that the pressure drop across the combined HEPA filters and charcoal adsorber banks is less than (6) inches Water Gauge while operating the system at a flow rate of $\mathrm{cfm} \pm 10 \%$.

2. Verifying that on a containment isolation test signal, the system automatically switches into a recirculation mode of operation with flow through the HEPA filters and charcoal adsorber banks.

3. Verifying that the system maintains the control room at a positive pressure of greater than or equal to $(1 / 4)$ inch $W$. G. relative to the outside atmosphere during system operation.

4. Verifying that the heaters dissipate when tested in accordance with ANSI $\sqrt{510-1975 . ~}$ 
f. After each complete or partial replacement of a HEPA filter hank by verifying that the HEPA filter banks remove greater than or equal to (99.95)\%* of the DOP when they are tested in-place in accordance with ANSI N510-1975 while operating the system at a flow rate of $\mathrm{cfm} \pm 10 \%$

g. After each complete or partial replacement of a charcoal adsorber bank by verifying that the charcoal adsorbers remove greater than or equal to $99.95 \%$ of a halogenated hydrocarbon refrigerant test gas when they are tested in-place in accordance with ANSI N510-1975 while operating the system at a flow rate of $\mathrm{cfm} \pm 10 \%$

ॠ99.95\% applicable when a filter efficiency of $99 \%$ is assumed in the safety analysis; $99 \%$ when a filter efficiency of $90 \%$ is assumed. 
PLANT SYSTEMS

3/4.7.8 ECCS PUMP ROOM EXHAUST AIR CLEANUP SYSTEM

LIMITING CONDITION FOR OPERATION

3.7.8 Two independent ECCS pump room exhaust air cleanup systems shall be OPERABLE.

APPLICABILITY: MODES $1,2,3$ and 4.

ACTION:

With one ECCS pump room exhaust air cleanup system inoperable, restore the inoperable system to OPERABLE status within 7 days or be in at least HOT STANDBY within the next 6 hours and in COLD SHUTDOWN within the following 30 hours.

\section{SURVEILLANCE REOUIREMENTS}

4.7.8 Each ECCS pump room exhaust air cleanup system shall be demonstrated OPERABLE:

a. At least once per 31 days on a STAGGERED TEST RASIS by initiating, from the control room, flow through the HEPA filters and charcoai adsorbers and verifying that the system operates for at least 10 hours with the heaters on.

b. At least once per 18 months or (1) after any structural maintenance on the HEPA filter or charcoal adsorber housings, or (2) following painting, fire or chemical release in any ventilation zone communicating with the system by:

1. Verifying that with the system operating at a flow rate of cfm $+10 \%$ and exhausting through the HEPA filters and charcoal adsorbers, the total bypass flow of the system to the facility vent, including leakage through the system diverting valves, is less than or equal to $1 \%$ when the system is tested by admitting cold DOP at the system intake. (For systems with diverting valves.) 


\section{PLANT SYSTEMS}

2. Verifying that the cleanup system satisfies the in-place testing acceptance criteria and uses the test procedures of Regulatory Positions C.5.a, C.5.c and C.5.d of Regulatory Guide 1.52, Revision 2, March 1978, and the system flow rate is $\mathrm{cfm} \pm 10 \%$.

3. Verifying within 31 days after removal that a laboratory analysis of a representative carbon sample obtained in accordance with Regulatory Position C.6.b of Regulatory Guide 1.52, Revision 2, March 1978, meets the laboratory testing criteria of Regulatory Position C.6.a of Regulatory Guide 1.52, Revision 2, March 1978.

4. Verifying a system flow rate of $\mathrm{cfm} \pm 10 \%$ during system operation when tested in accordance with ANSI N510-1975.

c. After every 720 hours of charcoal adsorber operation by verifying within 31 days after removal that a laboratory analysis of a representative carbon sample obtained in accordance with Regulatory Position C.6.b of Regulatory Guide 1.52, Revision 2, March 1978, meets the laboratory testing criteria of Regulatory Position C.6. a of Regulatory Guide 1.52, Revision 2, March 1978.

d. At least once per 18 months by:

1. Verifying that the pressure drop across the combined HEPA filters and charcoal adsorber banks is less than (6) inches Water Gauge while operating the system at a flow rate of $\mathrm{cfm} \pm 10 \%$.

2. Verifying that the system starts on a Safety Injection Actuation Test Signal.

3. Verifying that the filter cooling bypass valves can be manually opened.

4. Verifying that the heaters dissipate when tested in accordance with ANSI $\sqrt{510-1975}$. kw 


\section{PLANT SYSTEMS}

e. After each complete or partial replacement of a HEPA filter bank by verifying that the HEPA filter banks remove greater than or equal to (99.95)\%* of the DOP when they are tested in-place in accordance with ANSI N510-1975 while operating the system at a flow rate of $\mathrm{cfm} \pm 10 \%$.

f. After each complete or partial replacement of a charcoal absorber bank by verifying that the charcoal adsorbers remove greater than or equal to $99.95 \%$ of a halogenated hydrocarbon refrigerant test gas when they are tested in-place in accordance with ANSI N510-1975 while operating the system at a flow rate of $\_\mathrm{cfm} \pm 10 \%$.

×99.95\% applicable when a filter efficiency of $99 \%$ is assumed in the safety analyses; $99 \%$ when a filter efficiency of $90 \%$ is assumed. 
PLANT SYSTEMS

3/4.7.9 HYDRAULIC SNUBBERS

LIMITING CONDITION FOR OPERATION

3.7.9 All hydraulic snubbers listed in Table 3.7-4 shall be OPERABLE.

APPLICABILITY: MODES 1, 2, 3 and 4.

ACTION:

With one or more hydraulic snubbers inoperable, replace or restore the inoperable snubber(s) to OPERABLE status within 72 hours or be in at least HOT STANDBY within the next 6 hours and in COLD SHUTDOWN within the following 30 hours.

4.7.9 Hydraulic snubbers shall be demonstrated OPERABLE by performance of the following augmented inservice inspection program and the requirements of Specification 4.0.5.

a. Each hydraulic snubber with seal material fabricated from ethylene propylene or other materials demonstrated compatible with the operating environment and approved as such by the NRC, shall be determined OPERABLE at least once after not less than 4 months but within 6 months of initial criticality and in accordance with the inspection schedule of Table 4.7-2 thereafter, by a visual inspection of the snubber. Visual inspections of the snubbers shall include, but are not necessarily limited to, inspection of the hydraulic fluid reservoirs, fluid connections, and linkage connections to the piping and anchors. Initiation of the Table 4.7-2 inspection schedule shall be made assuming the unit was previously at the 6 month inspection interval.

b. Each hydraulic snubber with seal material not fabricated from ethylene propylene or other materials demonstrated compatible with the operating environment shall be determined OPERABLE at least once per 31 days by a visual inspection of the snubber. Visual inspections of the snubbers shall include, but are not necessarily limited to, inspection of the hydraulic fluid reservoirs, fluid connections, and linkage connections to the piping and anchors. 
PLANT SYSTEMS

SURVEILLANCE REQUIREMENTS (Continued)

c. At least once per 18 months during shutdown, a representative sample of at least 10 hydraulic snubbers or at least $10 \%$ of all snubbers listed in Table 3.7-4, whichever is less, shall be selected and functionally tested to verify correct piston movement, lock up and bleed. Snubbers greater than 50,000 1b. capacity may be excluded from functional testing requirements. Snubbers selected for functional testing shall be selected on a rotating basis. Snubbers identified as either "Especially Difficult to Remove" or in "High Radiation Zones" may be exempted from functional testing provided these snubbers were demonstrated OPERABLE during previous functional tests. Snubbers found inoperable during functional testing shall be restored to OPERABLE status prior to resuming operation. For each snubber found inoperable during these functional tests, an additional minimum of $10 \%$ of all snubbers or 10 snubbers, whichever is less, shall also be functionally tested until no more failures are found or all snubbers have been functionally tested. 
TABLE $3.7-4$

SAFETY RELATED HYDRAULIC SNUBBERS*

SNUBBER

NO.

SYSTEM SNUBBER INSTALLED

ON, LOCATION AND ELEVATION
ACCESSIBLE OR

INACCESSIBLE

(A or I)
HIGH RADIATION

ZONE

DURING SHUTDOWN**

(Yes or No)
ESPECIALLY DIFFICULT

TO REMOVE

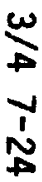

* Snubbers may be added to safety related systems without prior License Amendment to Table 3.7-4 provided that a revision to Table 3.7-4 is included with the next License Amendment request.

**Modifications to this column due to changes in high radiation areas may be made without prior License Amendment provided that a revision to Table 3.7-4 is included with the next License

है Amendment request. 


\section{TABLE 4.7-2}

克

\section{HYDRAULIC SNUBBER INSPECTION SCHEDULE}

NUMBER OF SNUBBERS FOUND INOPERABLE DURING INSPECTION OR DURING INSPECTION INTERVAL*

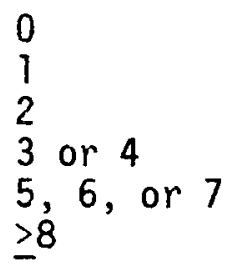

NEXT REQUIRED INSPECTION INTERVAL**

18 months $\pm 25 \%$
12 months $\mp 25 \%$
6 months $\mp 25 \%$
24 days $\mp 25 \%$
62 days $\mp 25 \%$
31 days $\mp 25 \%$

$\underset{\infty}{\omega}$

Ñ

"Snubbers may be categorized into two groups, "accessible" and "inaccessible". This categorization shall be based upon the snubber's accessibility for inspection during reactor operation. These two groups may be inspected independently according to the above schedule.

**The required inspection interval shall not be lengthened more than one step at a time and the provisions of Specification 4.0 .2 are not applicable. 
PLANT SYSTEMS

3/4.7.10 SEALED SOURCE CONTAMINATION

LIMITING CONDITION FOR OPERATION

3.7.10 Each sealed source containing radioactive material either in excess of 100 microcuries of beta and/or gamma emitting material or 5 microcuries of alpha emitting material shall be free of greater than or equal to 0.005 microcuries of removable contamination.

APPLICABILITY: At al1 times.

ACTION:

a. Each sealed source with removable contamination in excess of the above limit shall be immediately withdrawn from use and:

1. Either decontaminated and repaired, or

2. Disposed of in accordance with Commission Regulations.

b. The provisions of Specifications 3.0.3 and 3.0.4 are not applicable.

4.7.10.1 Test Requirements - Each sealed source shall be tested for leakage and/or contamination by:

a. The licensee, or

b. Other persons specifically authorized by the Commission or an Agreement State.

The test method shall have a detection sensitivity of at least 0.005 microcuries per test sample.

4.7.10.2 Test Frequencies - Each category of sealed sources (excluding startup sources and fission detectors previousiy subjected to core flux) shall be tested at the frequencies described below.

a. Sources in use - At least once per six months for all sealed sources containing radioactive material: 
PLANT SYSTEMS

SURVEILLANCE REQUIREMENTS (Continued)

1. With a half-life greater than 30 days (excluding Hydrogen 3), and

2. In any form other than gas.

b. Stored sources not in use - Each sealed source and fission detector shal1 be tested prior to use or transfer to another licensee unless tested within the previous six months. Sealed sources and fission detectors transferred without a certificate indicating the last test date shall be tested prior to being placed into use.

c. Startup sources and fission detectors - Each sealed startup source and fission detector shall be tested within 31 days prior to being subjected to core flux or installed in the core and following repair or maintenance to the source or detector.

4.7.10.3 Reports - A report shall be prepared and submitted to the Commission on an annual bas is if sealed source or fission detector leakage tests reveal the presence of greater than or equal to 0.005 microcuries of removable contamination. 
PLANT SYSTEMS

\section{3/4.7.11 FIRE SUPPRESSION SYSTEMS}

\section{FIRE SUPPRESSION WATER SYSTEM}

3.7.11.1 The fire suppression water system shall be OPERABLE with:

a. (Two) fire suppression pumps, each with a capacity of with their discharge aligned to the fire suppression header,

b. Separate water supplies, each with a minimum contained volume of gallons, and

c. An OPERABLE flow path capable of taking suction from the tank and the tank and transferring the water through distribution piping with OPERABLE sectionalizing control or isolation valves to the yard hydrant curb valves, the last valve ahead of the water flow alarm device on each sprinkler or hose standpipe, and the last valve ahead of the deluge valve on each deluge or spray system required to be OPERABLE per Specifications 3.7.11.2 and 3.7.11.6.

\section{APPLICABILITY: At all times.}

ACTION:

a. With one pump and/or one water supply inoperable, restore the inoperable equipment to OPERABLE status within 7 days or, in lieu of any other report required by Specification 6.9. 1 , prepare and submit a Special Report to the Commission pursuant to Specification 6.9.2 within the next 30 days outlining the plans and procedures to be used to restore the inoperable equipment to OPERABLE status or to provide an alternate backup pump or supply. The provisions of Specifications 3.0.3 and 3.0.4 are not applicable.

b. With the fire suppression water system otherwise inoperable:

1. Establish a backup fire suppression water system within 24 hours, and

2. In lieu of any other report required by Specification 6.9.1, submit a Special Report in accordance with Specification 6.9.2:

a) By telephone within 24 hours,

b) Confirmed by telegraph, mailgram or facsimile transmission no later than the first working day following the event, and 
PLANT SYSTEMS

ACTION: (Continued)

c) In writing within 14 days following the event, outlining the action taken, the cause of the inoperability and the plans and schedule for restoring the system to OPERABLE status.

\section{SURVEILLANCE REQUIREMENTS}

4.7.11.1.1 The fire suppression water system shal1 be demonstrated OPERABLE:

a. At least once per 7 days by verifying the contained water supply volume.

b. At least once per 31 days on a STAGGERED TEST BASIS by starting each pump and operating it for at least (15) minutes on recirculation flow.

c. At least once per 31 days by verifying that each valve (manual, power operated or automatic) in the flow path that is not locked, sealed, or otherwise secured in position, is in its correct position.

d. (At least once per 6 months by performance of a system flush.)

e. At least once per 12 months by cycling each testable valve in the flow path through at least one complete cycle of full travel.

f. At least once per 18 months by performing a system functional test which includes simulated automatic actuation of the system throughout its operating sequence, and:

1. Verifying that each automatic valve in the flow path actuates to its correct position,

2. Verifying that each pump develops at least (2500) gpm at a system head of (250) feet,

3. Cycling each valve in the flow path that is not testable during plant operation through at least one complete cycle of full trave 1 , and

4. Verifying that each fire suppression pump starts (sequentialiy) to maintain the fire suppression water system pressure greater than or equal to psig. 
PLANT SYSTEMS

SURVEILLANCE REQUIREMENTS (Continued)

g. At least once per 3 years by performing a flow test of the system in accordance with Chapter 5, Section 11 of the Fire Protection Handbook, 14th Edition, published by the National Fire Protection Association.

4.7.11.1.2 The fire pump diesel engine shall be demonstrated OPEPABLE:

a. At least once per 31 days by verifying:

1. The diesel fuel oil day storage tank contains at least gallons of fuel, and

2. The diesel starts from ambient conditions and operates for at least 30 minutes.

b. At least once per 92 days by verifying that a sample of diesel fuel from the fuel storage tank, obtained in accordance with ASTM-0270-65, is with in the acceptable limits specified in Table 1 of ASTM D975-74 when checked for viscosity, water and sediment.

c. At least once per 18 months during shutdown, by:

1. Subjecting the diesel to an inspection in accordance with procedures prepared in conjunction with its manufacturer's recommendations for the class of service, and

2. Verifying the diesel starts from ambient conditions on the auto-start signal and operates for greater than or equal to 30 minutes while loaded with the fire pump.

4.7.11.1.3 The fire pump diesel starting 24-volt battery bank and charger shall be demonstrated OPERABLE:

a. At least once per 7 days by verifying that:

1. The electrolyte level of each battery is above the plates, and

2. The overall battery voltage is greater than or equal to 24 volts. 


\section{PLANT SYSTEMS}

b. At least once per 92 days by verifying that the specific gravity is appropriate for continued service of the battery.

c. At least once per 18 months by verifying that:

1. The batteries, cell plates and battery racks show no visual indication of physical damage or abnormal deterioriation, and

2. The battery-to-battery and terminal connections are clean, tight, free of corrosion and coated with anti-corrosion material. 
PLANT SYSTEMS

SPRAY AND/OR SPRINKLER SYSTEMS

LIMITING CONDITION FOR OPERATION

3.7.11.2 The following spray and/or sprinkler systems shall be OPERABLE:

a. (Plant dependent - to be listed by name and location.)

b.

c.

APPLICABILITY: Whenever equipment in the spray/sprinkler protected areas is required to be OPERABLE.

ACTION:

a. With one or more of the above required spray and/or sprinkler systems inoperable, establish a continuous fire watch with backup fire suppression equipment for the unprotected area(s) within 1 hour; restore the system to OPERABLE status within 14 days or, in lieu of any other report required by Specification 6.9.1, prepare and submit a Special Report to the Commission pursuant to Specification 6.9 .2 within the next 30 days outlining the action taken, the cause of the inoperability and the plans and schedule for restoring the system to OPERABLE status.

b. The provisions of Specifications 3.0.3 and 3.0.4 are not applicable.

\section{SURVEILLANCE REQUIREMENTS}

4.7.11.2 Each of the above required spray and/or sprinkler systems shall be demonstrated OPERABLE:

a. At least once per 12 months by cycling each testable valve in the flow path through at least one complete cycle of full travel.

b. At least once per 18 months:

1. By performing a system functional test which includes simulated automatic actuation of the system, and:

a) Verifying that the automatic valves in the flow path actuate to their correct positions on a test signàl, and 
b) Cycling each valve in the flow path that is not testable during plant operation through at least one complete cycle of full travel.

2. By a visual inspection of the spray headers to verify their integrity, and

3. By a visual inspection of each nozzle's spray area to verify the spray pattern is not obstructed.

c. At least once per 3 years by performing an air flow test through each open head spray/sprinkler header and verifying each open head spray/ sprinkler nozzle is unobstructed. 


\section{PLANT SYSTEMS}

LOW PRESSURE $\mathrm{CO}_{2}$ SYSTEMS

3.7.11.3 The following low pressure $\mathrm{CO}_{2}$ systems shall be OPERABLE with a minimum level of storage $\operatorname{tank}(\mathrm{s})$. and a minimum pressure of in the associated

a. (Plant dependent - to be listed by name and location.)

b.

c.

APPLICABILITY: Whenever equipment in the low pressure $\mathrm{CO}_{2}$ protected areas is required to be OPERABLE.

\section{ACTION:}

a. With one or more of the above required low pressure $\mathrm{CO}_{2}$ systems inoperable, establish a continuous fire watch with backup fire suppression equipment for the unprotected area(s) within 1 hour; restore the system to OPERABLE status within 14 days or, in 1 ieu of any other report required by Specification 6.9 .1 , prepare and submit a Special Report to the Commission pursuant to Specification 6.9 .2 within the next 30 days outlining the action taken, the cause of the inoperability and the plans and schedule for restoring the system to OPERABLE status.

b. The provisions of Specifications 3.0 .3 and 3.0 .4 are not applicable. SURVEILLANCE REQUIREMENTS

4.7.11.3 Each of the above required low pressure $\mathrm{CO}_{2}$ systems shall be demonstrated OPERABLE:

a. At least once per 7 days by verifying $\mathrm{CO}_{2}$ storage tank level and pressure, and

b. At least once per 18 months by verifying:

1. The system valves and associated ventilation dampers and fire door release mechanisms actuate manually and automatically, upon receipt of a simulated actuation signal, and

2. Flow from each nozzle during a "Puff Test." 
PLANT SYSTEMS

HIGH PRESSURE $\mathrm{CO}_{2}$ SYSTEMS

LIMITING CONDITION FOR OPERATION

3.7.11.4 The following high pressure $\mathrm{CO}_{2}$ systems shall be OPERARLE with the storage tanks having at least $90 \%$ of fulf charge weight.

a. (Plant dependent - to be listed by name and location.)

b.

c.

APPLICABILITY: Whenever equipment in the high pressure $\mathrm{CO}_{2}$ protected areas is required to be OPERABLE.

ACTION:

a. With one or more of the above required high pressure $\mathrm{CO}_{2}$ systems inoperable, establish a continuous fire watch with backup fire suppression equipment for the unprotected area(s) within 1 hour; restore the system to OPERABLE status within 14 days or, in lieu of any other report required by Specification 6.9.1, prepare and submit a Special Report to the Commission pursuant to Specification 6.9.2 within the next 30 days outlining the action taken, the cause of the inoperability and the plans and schedule for restoring the system to OPERABLE status.

b. The provisions of Specifications 3.0 .3 and 3.0 .4 are not applicable. SURVEILLANCE REQUIREMENTS

4.7.11.4 Each of the above required high pressure $\mathrm{CO}_{2}$ systems shall be demons trated OPERABLE:

a. At least once per 6 months by verifying $\mathrm{CO}_{2}$ storage tank weight.

b. At least once per 18 months by:

1. Verifying the system, including associated ventilation dampers and fire door release mechanisms, actuates manually and automatically, upon receipt of a simulated test signal, and

2. Performance of a flow test through headers and nozzles to assure no blockage. 
3.7.11.5 The following Halon systems shall be OPERABLE with the storage tanks having at least $95 \%$ of full charge weight and $90 \%$ of full charge pressure.

a. (Plant dependent - to be listed by name and location.)

b.

c.

APPLICABILITY: Whenever equipment in the Halon protected areas is required to Be OPERABLE.

\section{ACTION:}

a. With one or more of the above required Halon systems inoperable, establish a continuous fire watch with backup fire suppression equipment for the unprotected area(s) within 1 hour; restore the system to OPERABLE status within 14 days or, in lieu of any other report required by Specification 6.9.1, prepare and submit a Special Report to the Commission pursuant to Specification 6.9.2 within the next 30 days outlining the action taken, the cause of the inoperability and the plans and schedule for restoring the system to OPERABLE status.

b. The provisions of Specifications 3.0 .3 and 3.0 .4 are not applicable. SURVEILLANCE REQUIREMENTS

4.7.11.5 Each of the above required Halon systems shall be demonstrated OPERABLE :

a. At least once per 6 months by verifying Halon storage tank weight and pressure.

b. At least once per 18 months by:

1. Verifying the system, including associated ventilation dampers and fire doore release mechanisms, actuates manually and automatically, upon receipt of a simulated test signal, and

2. Performance of a flow test through headers and nozzles to assure no blockage. 
PLANT SYSTEMS

FIRE HOSE STATIONS

LIMITING CONDITION FOR OPERATION

3.7.11.6 The fire hose stations shown in Table 3.7-5 shall be OPERABLE.

APPLICABILITY: Whenever equipment in the areas protected by the fire hose stations is required to be OPERABLE.

ACTION:

a. With one or more of the fire hose stations shown in Table 3.7-5 inoperable, route an additional equivalent capacity fire hose to the unprotected area(s) from an OPERABLE hose station within 1 hour.

b. The provisions of Specifications 3.0.3 and 3.0.4 are not applicable.

\section{SURVEILLANCE REQUIREMENTS}

4.7.11.6 Each of the fire hose stations shown in Table 3.7-5 shall be demonstrated OPERABLE:

a. At least once per 31 days by visual inspection of the station to assure all required equipment is at the station.

b. At least once per 18 months by:

1. Removing the hose for inspection and re-racking, and

2. Inspecting all gaskets and replacing and degraded gaskets in the couplings.

c. At least once per 3 years by:

1. Partially opening each hose station valve to verify valve OPERABILITY and no flow blockage.

2. Conducting a hose hydrostatic test at a pressure at least 50 psig greater than the maximum pressure available at any hose station. 
TABLE 3.7-5

FIRE HOSE STATIONS

* [ist all Fire Hose Stations required to ensure the OPERABILITY of safety related equipment. 
PLANT SYSTEMS

YARD FIRE HYDRANTS AND HYDRANT HOSE HOUSES

LIMITING CONDITION FOR OPERATION

3.7.11.7 The yard fire hydrants and associated hydrant hose houses shown in Table 3.7-6 shall be OPERABLE.

APPLICABILITY: Whenver equipment in the areas protected by the yard fire hydrants is required to be OPERABLE.

ACTION:

a. With one or more of the yard fire hydrants or associated hydrant hose houses shown in Table 3.7-6 inoperable, within 1 hour have sufficient additional lengths of $21 / 2$ inch diameter hose located in an adjacent OPERABLE hydrant hose house to provide service to the unprotected area(s).

b. The provisions of Specifications 3.0.3 and 3.0.4 are not applicable.

SURVEILLANCE REQUIREMENTS

4.7.11.7 Each of the yard fire hydrants and associated hydrant hose houses shown in Table 3.7-6 shall be demonstrated OPERABLE:

a. At least once per 31 days by visual inspection of the hydrant hose house to assure all required equipment is at the hose house.

b. At least once per 6 months (once during March, April or May and once during September, October or November) by visually inspecting each yard fire hydrant and verifying that the hydrant harrel is dry and that the hydrant is not damaged.

c. At least once per 12 months by:

1. Conducting a hose hydrostatic test at a pressure at least 50 psig greater than the maximum pressure available at any yard fire hydrant.

2. Inspecting all the gaskets and replacing any degraded gaskets in the couplings.

3. Performing a flow check of each hydrant to verify its OPERABILITY. 
TABLE $3.7-6$

YARD FIRE HYDRANTS AND ASSOCIATED HYDRANT HOSE HOUSES

LOCATION* $\quad$ HYDRANT NUMBER

\#[ist al1 Yard Fire Hydrants and Hydrant Hose Houses required to ensure the OPERABILITY of safety related equipment. 


\section{PLANT SYSTEMS}

\section{3/4.7.12 FIRE BARRIER PENETRATIONS}

\section{LIMITING CONDITION FOR OPERATION}

3.7.12 All fire barrier penetrations (including cable penetration barriers, fire doors and fire dampers), in fire zone boundaries, protecting safety related areas shall be functional.

\section{APPLICABILITY: At all times.}

\section{ACTION:}

a. With one or more of the above required fire barrier penetrations non-functional, within one hour either, establish a continuous fire watch on at least one side of the affected penetration or verify the OPERABILITY of fire detectors on at least one side of the non-functional fire barrier and establish a hourly fire watch patrol. Restore the non-functional fire barrier penetration(s) to functional status within 7 days or, in 1 ieu of any other report required by Specification 6.9.1, prepare and submit a Special Report to the Commission pursuant to Specification 6.9 .2 within the next 30 days outlining the action taken, the cause of the non-functional penetration and plans and schedule for restoring the fire barrier penetration(s) to functional status.

b. The provisions of Specifications 3.0.3 and 3.0.4 are not applicable.

\section{SURVEILLANCE REQUIREMENTS}

4.7.12 Each of the above required fire barrier penetrations shall be verified to be functional:

a. At least once per 18 months by a visual inspection.

b. Prior to returning a fire barrier penetration to functional status following repairs or maintenance by performance of a visual inspection of the affected fire barrier penetration(s). 
3/4.7.13 AREA TEMPERATURE MONITORING

3.7.13 The temperature of each area shown in Table $3.7-7$ shall be maintained within the limits indicated in Table 3.7-7.

APPLICABILITY: Whenever the equipment in an affected area is required to be OPERABLE.

ACTION:

a. With one or more areas exceeding the temperature limit(s) for equipment not operating shown in Table 3.7-7 for more than eight hours, prepare and submit a Special Report to the Commission pursuant to Specification 6.9.2 within the next 30 days providing a record of the cumulative time the temperature in the affected area exceeded its limit.

b. With a temperature exceeding the limit for equipment operating, in addition to submitting a Special Report as described in ACTION a. above, within 4 hours, either restore the area to within its temperature limit or declare the equipment in the affected area inoperable.

c. The provisions of Specifications 3.0.3 and 3.0.4 are not applicable.

SURVEILLANCE REQUIREMENTS

4.7.13 The temperature in each of the areas of Specification 3.7.13 shall be determined to be within its limit at least once per 24 hours. 


\section{TABLE 3.7-7}

AREA TEMPERATURE MONITORING

AREA

1.

2.

3.

4.

5.
TEMPERATURE LIMIT $\left({ }^{\circ} \mathrm{F}\right)$ EQUIPMENT EQUIPMENT NOT OPERATING OPERATING 


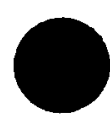

-

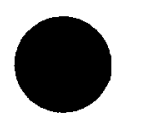


3/4.8 ELECTRICAL POWER SYSTEMS

$3 / 4.8 .1$ A.C. SOURCES

OPERATING

LIMITING CONDITION FOR OPERATION

3.8.1.1 As a minimum, the following A.C. electrical power sources shall be OPERABLE:

a. Two physically independent circuits between the offsite transmission network and the onsite Class IE distribution system, and

b. Two separate and independent diesel generators each with:

1. Separate day and engine-mounted fuel tanks containing a minimum volume of gallons of fuel,

2. A separate fuel storage system containing a minimum volume of gallons of fuel, and

3. A separate fuel transfer pump.

APPLICABILITY: MODES $1,2,3$ and 4.

ACTION:

a. With either an offsite circuit or diesel generator of the above required A.C. electrical power sources inoperable, demonstrate the OPERABILITY of the remaining A.C. sources by performing Surveillance Requirements 4.8.1.1.1.a and 4.8.1.1.2.a.4 within one hour and at least once per 8 hours thereafter; restore at least two offsite circuits and two diesel generators to OPERABLE status within 72 hours or be in at least HOT STANDBY within the next 6 hours and in COLD SHUTDOWN within the following 30 hours.

b. With one offsite circuit and one diesel generator of the above required A.C. electrical power sources inoperable, demonstrate the OPERABILITY of the remaining A.C. sources by performing Surveillance Requirements 4.8.1.1.1.a and 4.8.1.1.2.a.4 within one hour and at least once per 8 hours thereafter; restore at least one of the inoperable sources to OPERABLE status within 12 hours or be in at least HOT STANDBY within the next 6 hours and in COLD SHUTDOWN within the following 30 hours. Restore at least two offsite circuits and two diesel generators to OPERABLE status within 72 hours from the time of initial loss or be in at least HOT STANDBY within the next 6 hours and in COLD SHUTDOWN within the following 30 hours. 


\section{ELECTRICAL POWER SYSTEMS}

ACTION (Continued)

c. With two of the above required offsite A.C. circuits inoperable, demonstrate the OPERABILITY of two diesel generators by performing Surveillance Requirement 4.8.1.1.2.a.4 within one hour and at least once per 8 hours thereafter, unless the diesel generators are already operating; restore at least one of the inoperable offsite sources to OPERABLE status within 24 hours or be in at least HOT STANDBY within the next 6 hours. With only one offsite source restored, restore at least two offsite circuits to OPERABLE status within 72 hours from time of initial loss or be in at least HOT STANDBY within the next 6 hours and in COLD SHUTDOWN within the following 30 hours.

d. With two of the above required diesel generators inoperable, demonstrate the OPERABILITY of two offsite A.C. circuits by performing Surveillance Requirement 4.8.1.1.1.a within one hour and at least once per 8 hours thereafter; restore at least one of the inoperable diesel generators to OPERABLE status within 2 hours or be in at least HOT STANDBY within the next 6 hours and in COLD SHUTDOWN within the following 30 hours. Restore at least two diesel generators to OPERABLE status within 72 hours from time of initial loss or be in at least HOT STANDBY within the next 6 hours and in COLD SHUTDOWN within the following 30 hours.

\section{SURVEILLANCE REQUIREMENTS}

4.8.1.1.1 Each of the above required independent circuits between the offsite transmission network and the onsite Class $1 E$ distribution system shall be:

a. Determined OPERABLE at least once per 7 days by verifying correct breaker alignments, indicated power availablity, and

b. Demonstrated OPERABLE at least once per 18 months during shutdown by transferring (manually and automatically) unit power supply from the normal circuit to the alternate circuit.

4.8.1.1.2 Each diesel generator shall be demonstrated OPERABLE:

a. In accordance with the frequency specified in Table 4.8-1 on a STAGGERED TEST BASIS by:

1. Verifying the fuel level in the day and engine-mounted fuel tank,

2. Verifying the fuel level in the fuel storage tank, 
ELECTRICAL POWER SYSTEM

SURVEILLANCE REQUIREMENTS (Continued)

3. Verifying the fuel transfer pump can be started and transfers fuel from the storage system to the day and engine-mounted tank,

4. Verifying the diesel starts from ambient condition and accelerates to at least (900) rpm in less than or equal to (10) seconds. The generator voltage and frequency shall be volts and $\pm \quad \mathrm{Hz}$ within seconds after the start signal of the diesel generator shall be started for this test by using the following signals which shall be changed on a rotating basis:
a) Manual.
b) Simulated loss of offsite power by itself.
c) Simulated loss of offsite power in conjunction with an ESF actuation test signal.
d) An ESF actuation test signal by itself.

5. Verifying the generator is synchronized, loaded to greater than or equal to (continuous rating) $\mathrm{kw}$ in less than or equal to (60) seconds, and operates for greater than or equal to 60 minutes, and

6. Verifying the diesel generator is aligned to provide standby power to the associated emergency busses.

b. At least once per 92 days by verifying that a sample of diesel fuel from the fuel storage tank obtained in accordance with ASTM-D270-65, is within the acceptable limits specified in Table 1 of ASTM 0975-74 when checked for viscosity, water and sediment.

c. At least once per 18 months during shutdown by:

1. Subjecting the diesel to an inspection in accordance with procedures prepared in conjunction with its manufacturer's recommendations for this class of standby service.

2. Verifying the generator capability to reject a load of greater than or equal to (largest single emergency load) kw while maintaining voltage at $\mathrm{Hz}$. 
3. Verifying the generator capability to reject a load of (continuous rating) $\mathrm{kw}$ without exceeding $75 \%$ of the difference between nominal speed and the overspeed trip setpoint, or 15\% above nominal, whichever is lower. The generator voltage shall not exceed volts during and following the load rejection.

4. Simulating a loss of offsite power by itself, and:

a) Verifying de-energization of the emergency busses and load shedding from the emergency busses.

b) Verifying the diesel starts on the auto-start signal, energizes the emergency busses with permanently connected loads within seconds, energizes the auto-connected shutdown loads through the load sequencer and operates for greater than or equal to 5 minutes while its generator is loaded with the shutdown loads. After energization, the voltage and frequency of the emergency busses shall be maintained at $\pm$ volts and $\pm$ $\mathrm{Hz}$ during this test.

5. Verifying that on an ESF actuation test signal (without loss of offsite power) the diesel generator starts on the auto-start signal and operates on standby for greater than or equal to 5 minutes. The generator voltage and frequency shall be volts and $\pm$ $\mathrm{Hz}$ within seconds after the auto-start signal; the generator voltage and fregency shall be maintained within these limits during this test.

6. Verifying that on a simulated loss of the diesel generator (with offsite power not available), the loads are shed from the emergency busses and that subsequent loading of the diesel generator is in accordance with design requirements.

7. Simulating a loss of offsite power in conjunction with an ESF actuation test signal, and

a) Verifying de-energization of the emergency busses and load shedding from the emergency busses.

b) Verifying the diesel starts from ambient condition on the auto-start signal, energizes the emergency busses with permanently connected (accident) loads, within 
seconds, energizes the auto connected shutdown loads through the load sequencer and operates for greater than or equal to 5 minutes while its generator is loaded with the emergency loads. After energization, the voltage and frequency of the emergency busses shall be maintained at $\pm$ volts and $\pm$ $\mathrm{Hz}$ during this test.

c) Verifying that all automatic diesel generator trips, except engine overspeed and generator differential, are automatically bypassed upon loss of voltage on the emergency bus concurrent with a safety injection actuation signal.

8. Verifying the diesel generator operates for at least 24 hours. During the first 2 hours of this test, the diesel generator shall be loaded to greater than or equal to (2-hour rating) $\mathrm{kw}$ and during the remaining 22 hours of this test, the diesel generator shall be loaded to greater than or equal to (continuous rating) $\mathrm{kw}$. Within 5 minutes after completing this 24 hour test, perform Specification 4.8.1.1.2.c.4. The generator voltage and freqency shall be $\pm$ volts and $\mathrm{Hz}$ within seconds after the start signal; the generator voltage and frequency shall be maintained within these limits during this test.

9. Verifying that the auto-connected loads to each diesel generator do not exceed the 2000 hour rating of kw.

10. Verifying the diesel generator's capability to:

a) Synchronize with the offsite power source while the generator is loaded with its emergency loads upon a simulated restoration of offsite power,

b) Transfer its loads to the offsite power source, and

c) Be restored to its standby status.

11. Verifying that with the diesel generator operating in a test mode (connected to its bus), a simulated safety injection signal overrides the test-mode by (1) returning the diesel generator to standby operation and (2) automatically energizes the emergency loads with offsite power.

12. Verifying that the fuel transfer pump transfers fuel from each fuel storage tank to the day and engine-mounted tank of each diesel via the installed cross connection lines. 
13. Verifying that the automatic load sequence timer is OPERABLE with the interval between each load block within $\pm 10 \%$ of its design interval.

14. Verifying that the following diesel generator lockout features prevent diesel generator starting only when required:

a)

b)

d. At least once per 10 years or after any modifications which could affect diesel generator interdependence by starting hoth diesel generators simultaneously, during shutdown, and verifying that both diesel generators accelerate to at least (900) rpm in less than or equal to (10) seconds.

4.8.1.1.3 Reports - All diesel generator failures, valid or non-valid, shall be reported to the Commission pursuant to Specification 6.9.1. Reports of diesel generator failures shall include the information recommended in Regulatory Position C.3.b of Regulatory Guide 1.108, Revision 1, August 1977. If the number of failures in the last 100 valid tests (on a per nuclear unit basis) is greater than or equal to 7 , the report shall be supplemented to include the additional information recommended in Regulatory Position C.3.b of Regulatory Guide 1.108, Revision 1, August 1977. 
TABLE $4.8-1$

DIESEL GENERATOR TEST SCHEDULE

Number of Failures In

Last $100 \mathrm{Valid}$ Tests. *

$\leq 1$

At least once per 31 days

2

At least once per 14 days

3

At least once per 7 days

$\geq 4$

At least once per 3 days

*Criteria for determining number of failures and number of valid tests shall be in accordance with Regulatory Position C.2.e of Regulatory Guide 1.108, Revision 1, August 1977, where the last 100 tests are determined on a per nuclear unit basis. For the purposes of this test schedule, only valid tests conducted after the operating License issuance date shall be included in the computation of the "last 100 valid tests". Entry into this test schedule shall be made at the 31 day test frequency. 


\section{ELECTRICAL POWER SYSTEMS}

SHUTDOWN

3.8.1.2 As a minimum, the following A.C. electrical power sources shall be OPERABLE:

a. One circuit between the offsite transmission network and the onsite Class IE distribution system, and

b. One diesel generator with:

1. Day and engine-mounted fuel tanks containing a minimum volume of gallons of fuel,

2. A fuel storage system containing a minimum volume of gallons of fuel, and

3. A fuel transfer pump.

APPLICABILITY: MODES 5 and 6.

ACTION:

With iess than the above minimum required A.C. electrical power sources OPERABLE, suspend all operations involving CORE ALTERATIONS or positive reactivity changes.

4.8.1.2 The above required A.C. electrical power sources shall be demonstrated OPERABLE by the performance of each of the Surveillance Requirements of 4.8.1.1.1, 4.8.1.1.2 (except for requirement 4.8.1.1.2.a.5) and 4.8.1.1.3. 
ELECTRICAL POWER SYSTEMS

3/4.8.2 ONSITE POWER DISTRIBUTION SYSTEMS

A.C. DISTRIBUTION - OPERATING

LIMITING CONDITION FOR OPERATION

3.8.2.1 The following A.C. electrical busses shall be OPERABLE and energized with tie breakers open between redundant busses:

$\begin{array}{ll}(4160) & \text { volt Emergency Bus \# } \\ (4160) & \text { volt Emergency Bus \# } \\ (480) & \text { volt Emergency Bus \# } \\ (480) & \text { volt Emergency Bus \# } \\ (120) & \text { volt A.C. Vital Bus \# } \\ (120) & \text { volt A.C. Vital Bus \# } \\ (120) & \text { volt A.C. Vital Bus \# } \\ (120) & \text { volt A.C. Vital Bus \# }\end{array}$

APPLICABILITY: MODES 1,2,3 and 4.

ACTION:

With less than the above complement of A.C. busses OPERABLE, restore the inoperable bus to OPERABLE status within 8 hours or be in at least HOT STANDBY within the next 6 hours and in COLD SHUTDOWN within the following 30 hours.

\section{SURVEILLANCE REQUIREMENTS}

4.8.2.1 The specified A.C. busses shall be determined OPERABLE with tie breakers open between redundant busses at least once per 7 days by verifying correct breaker alignment and indicated power availability. 
ELECTRICAL POWER SYSTEMS

A.C. DISTRIBUTION - SHUTDOWN

LIMITING CONDITION FOR OPERATION

3.8.2.2 As a minimum, the following A.C. electrical busses shall be OPERABLE:

1 - (4160) volt Emergency Bus

1 - (480) volt Emergency Bus

2 - (120) volt A.C. Vital Busses

APPLICABILITY: MODES 5 and 6

ACTION:

With less than the above complement of A.C. busses OPERABLE and energized, establish CONTAINMENT INTEGRITY within 8 hours.

4.8.2.2 The specified A.C. busses shall be determined OPERABLE at least once per 7 days by verifying correct breaker alignment and indicated power availability. 
ELECTRICAL POWER SYSTEMS

D.C. DISTRIBUTION - OPERATING

LIMITING CONDITION FOR OPERATION

3.8.2.3 The following D.C. bus trains shall be energized and OPERABLE:

TRAIN "A" consisting of (250/125)-volt D.C. bus No. 1, (250/125)-volt D.C. battery bank No. 1 and a full capacity charger.

TRAIN "B" consisting of (250/125)-volt D.C. bus No. 2, (250/125)-volt D.C. battery bank No. 2 and a full capacity charger.

APPLICABILITY: MODES $1,2,3$ and 4.

ACTION:

With one (250/125)-volt D.C. bus train inoperable, restore the inoperable bus train to OPERABLE status within 2 hours or be in at least HOT STANDBY within the next 6 hours and in COLD SHUTDOWN within the following 30 hours.

\section{SURVEILLANCE REQUIREMENTS}

4.8.2.3.1 Each D.C. bus train shall be determined OPERABLE and energized with tie breakers open at least once per 7 days by verifying correct breaker alignment and indicated power availability with an overall voltage of greater than or equal to $(250 / 125)$ volts.

4.8.2.3.2 Each (250/125)-volt battery bank and charger shall be demonstrated OPERABLE:

a. At least once per 7 days by verifying that:

1. The electrolyte level of each pilot cell is between the minimum and maximum level indication marks,

2. The pilot cell specific gravity, corrected to (77) ${ }^{\circ} \mathrm{F}$ and full electrolyte level, is greater than or equal to , and

3. The pilot cell voltage is greater than or equal to volts.

b. At least once per 92 days by verifying that:

1. The electrolyte level of each cell is between the minimum and maximum level indication marks, 
ELECTRICAL POWER SYSTEMS

SURVEILLANCE REQUIREMENTS (Continued)

2. The average specific gravity of each connected cell, corrected to $(77)^{\circ} \mathrm{F}$ and full electrolyte level, is greater than or equal to $(1.200)$,

3. The electrolyte level in a representative sample of cells consisting of at least every sixth cell are within $\pm 5^{\circ} \mathrm{F}$,

4. The minimum specific gravity, corrected to $\left(77^{\circ}\right) \mathrm{F}$ and full electrolyte level, of each connected cell is within 0.010 of the average corrected value of all the connected cells,

5. The voltage of each connected cell is within \pm 0.04 volts of the average voltage of all the connected cells,

6. The total battery terminal voltage is greater than or equal to volis, and

7. The battery load (charger current) with the battery on float charge is less than amps.

c. At least once per 18 months by verifying that:

1. The cells, cell piates and battery racks show no visual indication of physical damage or deterioration,

2. The cell-to-cell and terminal connections are clean, tight, and coated with anti-corrosion material,

3. The resistance of each cell-to-cell and terminal connection is less than or equal to ohms, and

4. The battery charger will supply at least __ amperes at a minimum of volts for at least (8) hours.

d. At least once per 18 months, during shutdown, by verifying that the battery capacity is adequate to supply and maintain in OPERABLE status all of the actual emergency loads for (8) hours when the battery is subjected to a battery service test.

e. At least once per 60 months, during shutdown, by verifying that the battery capacity is at least $90 \%$ of the manufacturer's rating when subjected to a performance discharge test. This performance discharge test shall be performed subsequent to the satisfactory completion of the required battery service test. 
ELECTRICAL POWER SYSTEMS

D.C. DISTRIBUTION - SHIJTDOWN

LIMITING CONDITION FOR OPERATION

3.8.2.4 As a minimum, one D.C. bus train consisting of the following shall be energized and OPERABLE:

1 - (250/125)-volt D.C. bus, and

1 - (250/125)-volt battery bank and full capacity charger associated with the above D.C. bus.

APPLICABILITY: MODES 5 and 6.

ACTION:

With less than the above complement of D.C. equipment and bus OPERABLE, establish CONTAINMENT INTEGRITY within 8 hours.

4.8.2.4.1 The above required (250/125)-volt D.C. bus shall be determined OPERABLE and energized at least once per 7 days by verifying correct breaker alignment and indicated power availability with an overall voltage of greater than or equal to $(250 / 125)$ volts.

4.8.2.4.2 The above required (250/125)-volt battery bank and charger shall be demonstrated OPERABLE per Surveillance Requirement 4.8.2.3.2. 
ELECTPICAL POWER SYSTEMS

3/4.8.3 ELECTRICAL EQUIPMENT PROTECTIVE DEVICES

CONTAIMMENT PENETRATION CONDIICTOR NVERCIJRRENT PROTECTIVE NEVICES

LIMITING CONDITION FOR OPERATION

3.8.3.] All containment penetration conductor overcurrent protective devices shown in Table $3.8-1$ shall be OPERABLE.

APPLICABILITY: MODES $1,2,3$ and 4.

ACTION:

With one or more of the containment penetration conductor overcurrent protective devices shown in Table 3.8-1 inoperable:

a. Restore the protective device(s) to OPFRABLE status or de-eneraize the circuits(s) by tripping the associated backup circuit breaker within 72 hours and verify the hackup circuit breaker to he tripped at least once per 7 days thereafter; the provisions of Specification 3.0.4 are not applicable to overcurrent devices in circuits which have their backup circuit breakers tripped, or

b. Re in at least HOT STANDRY within the next 6 hours and in CNLD SHUTDOWN within the following 30 hours.

4.8.3.1 All containment penetration conductor overcurrent protective devices shown in Table 3.8-1 shall be demonstrated OPERABLE:

a. At least once per 18 months:

1. By verifying that the medium voltage (4-15 KV) circuit breakers are OPERABLE by selecting, on a rotating basis, at least $10 \%$ of the circuit breakers of each voltage level, and performina the following:

(a) A CHANNEL CALIBRATION of the associated protective relays, and

(b) An integrated system functional test which includes simulated automatic actuation of the system and verifying that each relay and associated circuit breakers and control circuits function as desianed and as specified in Table 3.8.1. 
FLECTPICAL POWER SYSTEMS

SIIRVEILLANCE REOUIREMENTS (Continued)

(c) For each circuit breaker found inoperable during these functional tests, an additional representative sample of at least $10 \%$ of a 11 the circuit breakers of the inoperable type shall also be functionally tested until no more failures are found or all circuit breakers of that type have been functionally tested.

2. Ry selecting and functionally testing a representative sample of at least $10 \%$ of each type of lower voltage circuit breakers. Circuit breakers selected for functional testing shall he selected on a rotating basis. The functional test shall consist of injecting a current input at the specified setpoint to each selected circuit breaker and verifying that each circuit breaker functions as designed. Circuit hreakers found inoperable during functional testing shall be restored to OPERABLE status prior to resuming operation. For each circuit breaker found inoperable during these functional tests, an additional representative sample of at least $10 \%$ of a 11 the circuit breakers of the inoperable type shall also be functionally tested until no more failures are found or all circuit breakers of that type have been functionally tested.

3. By selecting and functionally testing a representative sample of each type of fuse on a rotating basis. Each representative sample of fuses shall include at least $10 \%$ of all fuses of that type. The functionally test shall consist of a non-destructive resistance measurement test which demonstrates that the fuse meets it manufacturer's design criteria. Fuses found inoperable during these functional tests shall be replaced with OPERABLE fuses prior to resuming operation. For each fuse found inoperable during these functional tests, an additional representative sample of at least $10 \%$ of all fuses of that type shall be functionally tested until no more failures are found or all fuses of that type have been functionally tested.

b. At least once per 60 months by subjecting each circuit hreaker to an inspection and preventive maintenance in accordance with procedures prepared in conjunction with its manufacturer's recommendations. 
TABLE $3.8-1$

CONTAINMENT PENETRATION CONDUCTOR

OVERCURRENT PROTECTIVE DEVICES

Device Number and Location

1. 6900 VAC

(Primary breaker)

\begin{tabular}{cc} 
Trip & Response \\
Setpoint & Time \\
(Amperes) & (sec/cycles) \\
\hline
\end{tabular}

System Powered

Reactor Coolant pump

2. 480 VAC from MOAD Centers

List all; primary breakers

Back-up breakers

3. 480 VAC from MCC

List all; primary breakers

Back-up breakers

" "

5. 440 VAC CEADM Power

Primary breakers

Back-up breakers 
ELECTRICAL POWER SYSTEMS

MOTOR OPERATED VALVES THERMAL OVERLOAD PROTECTION AND/OR BYPASS DEVICES

LIMITING CONDITION FOR OPERATION

3.8.3.2 The thermal overload protection and/or bypass devices, integral with the motor starter, of each valve listed in Table 3.8.2 shall be OPERABLE.

APPLICABILITY: Whenever the motor operated valve is required to be OPERABLE.

ACTION:

With one or more of the thermal overload protection and/or bypass devices inoperable, declare the affected valve(s) inoperable and apply the appropriate ACTION Statement(s).

\section{SURVEILLANCE REQUIREMENTS}

4.8.3.2 The above required thermal overload protection and/or bypass devices shall be demonstrated OPERABLE:

a. At least once per 18 months, by the performance of a CHANNEL FUNCTIONAL TEST of the bypass circuitry for those thermal overload devices which are either:

1. Continuously bypassed and temporarily placed in force only when the valve motors are undergoing periodic or maintenance testing, or

2. Normally in force during plant operation and bypassed under accident conditions.

b. At least once per 18 months by the performance of a CHANNEL CALIBRATION of a representative sample of at least $25 \%$ of all thermal overload devices which are not bypassed, such that each non-bypassed device is calibrated at least once per 6 years. 
TABLE $3.8-2$

MOTOR OPERATED VALVES THERMAL OVERLOAD

PROTECTION AND/OR BYPASS DEVICES

VALVE NUMBER

FUNCTION

BYPASS DEVICE

(YES/NO) 


\section{3/4.9 REFUELING OPERATIONS}

3/4.9.1 BORON CONCENTRATION

LIMITING CONDITION FOR OPERATION

3.9.1 With the reactor vessel head unbolted or removed, the boron concentration of all filled portions of the Reactor Coolant System and the refueling canal shall be maintained uniform and sufficient to ensure that the more restrictive of following reactivity conditions is met:

a. Either a $\mathrm{K}$ eff 0.95 or less, which includes a $1 \%$ delta $\mathrm{k} / \mathrm{k}$ conservative allowance for uncertainties, or

b. A boron concentration of greater than or equal to (1731) ppm, which includes a $50 \mathrm{ppm}$ conservative allowance for uncertainties.

APPLICABILITY: MODE 6*.

ACTION:

With the requirements of the above specification not satisfied, immediately suspend all operations involving CORE ALTERATIONS or positive reactivity changes and initiate and continue boration at greater than or equal to (40) $\mathrm{gpm}$ of (1731) ppm boric acid solution or its equivalent until $\mathrm{K}_{\text {eff }}$ is reduced to less than or equal to 0.95 or the boron concentration is restofed to greater than or equal to (1731) $\mathrm{ppm}$, whichever is the more restrictive. The provisions of Specification 3.0.3 are not applicable.

\section{SURVEILLANCE REQUIREMENTS}

4.9.1.1 The more restrictive of the above two reactivity conditions shall be determined prior to:

a. Removing or unbolting the reactor vessel head, and

b. Withdrawal of any full length CEA in excess of 3 feet from its fully inserted position within the reactor pressure vessel.

4.9.1.2 The boron concentration of the reactor coolant system and the refueling canal shall be determined by chemical analysis at least once per 72 hours.

*The reactor shall be maintained in MODE 6 whenever the reactor vessel head is unbolted or removed and fuel is in the reactor vessel. 


\section{REFUELING OPERATIONS}

\section{$3 / 4.9 .2$ INSTRUMENTATION}

3.9.2 As a minimum, two source range neutron flux monitors shall be operating, each with continuous visual indication in the control room and one with audible indication in the containment and control room.

\section{APPLICABILITY: MODE 6.}

ACTION:

a. With one of the above required monitors inoperable, immediately suspend all operations involving CORE ALTERATIONS or positive reactivity changes.

b. With both of the above required monitors inoperable, determine the boron concentration of the reactor coolant system at least once per 12 hours.

c. The provisions of Specification 3.0.3 are not applicable.

\section{SURVEILLANCE REQUIREMENTS}

4.9.2 Each source range neutron flux monitor shall be demonstrated OPERABLE by performance of:

a. A CHANNEL CHECK at least once per 12 hours,

b. A CHANNEL FUNCTIONAL TEST within 8 hours prior to the initial start of CORE ALTERATIONS, and

c. A CHANNEL FUNCTIONAL TEST at least once per 7 days. 


\section{REFUELING OPERATIONS}

\section{3/4.9.3 DECAY TIME}

3.9.3 The reactor shall be subcritical for at least (72) hours.

APPLICABILITY: During movement of irradiated fuel in the reactor pressure vesse1.

\section{ACTION:}

With the reactor subcritical for less than (72) hours, suspend all operations involving movement of irradiated fuel in the reactor pressure vesse?. The provisions of Specification 3.0 .3 are not applicable.

4.9.3 The reactor shall be determined to have been subcritical for at least (72) hours by verification of the date and time of subcriticality prior to movement of irradiated fuel in the reactor pressure vessel. 
REFUELING OPERATIONS

3/4.9.4 CONTAINMENT BUILDING PENETRATIONS

LIMITING CONDITION FOR OPERATION

3.9.4 The containment building penetrations shall be in the following status:

a. The equipment door closed and held in place by a minimum of four bolts,

b. A minimum of one door in each airlock is closed, and

c. Each penetration providing direct access from the containment atmosphere to the outside atmosphere shall be either:

1. Closed by an isolation valve, blind flange, or manual valve, or

2. Be capable of being closed by an OPERABLE automatic containment purge valve.

APPLICABILITY: During CORE ALTERATIONS or movement of irradiated fuel within the containment.

ACTION:

With the requirements of the above specification not satisfied, immediately suspend all operations involving CORE ALTERATIONS or movement of irradiated fuel in the containment building. The provisions of Specification 3.0.3 are not applicable.

SURVEILLANCE REQUIREMENTS

4.9.4 Each of the above required containment building penetrations shall be determined to be either in its cilosed/isolated condition or capable of being closed by an OPERABLE automatic containment purge valve within 72 hours prior to the start of and at least once per 7 days during CORE ALTERATIONS or movement of irradiated fuel in the containment building by:

a. Verifying the penetrations are in their closed/isolated condition, or

b. Testing the containment purge valves per the applicable portions of Specification $(4 \cdot 6.4 .2)$. 
REFUELING OPERATIONS

3/4.9.5 COMMUNICATIONS

LIMITING CONDITION FOR OPERATION

3.9.5 Direct communications shall be maintained between the control room and personnel at the refueling station.

APPLICABILITY: During CORE ALTERATIONS.

ACTION:

When direct communications between the control room and personnel at the refueling station cannot be maintained, suspend all CORE ALTERATIONS. The provisions of Specification 3.0.3 are not applicable.

4.9.5 Direct communications between the control room and personnel at the refueling station shall be demonstrated within one hour prior to the start of and at least once per 12 hours during CORE ALTERATIONS. 
REFUELING OPERATIONS

3/4.9.6 MANIPULATOR CRANE OPERABILITY

LIMITING CONDITION FOR OPERATION

3.9.6 The manipulator cranes shall be used for movement of CEAs or fuel assemblies and shall be OPERABLE with:

a. A minimum capacity of _ pounds, and

b. An overload cut off limit of less than or equal to __ pounds.

APPLICABILITY: During movement of CEAs or fuel assemblies within the reactor pressure vessel.

ACTION:

With the requirements for crane OPERABILITY not satisfied, suspend use of any inoperable manipulator crane from operations invoiving the movement of CEAs and fuel assemblies within the reactor pressure vessel. The provisions of Specification 3.0.3 are not applicable.

4.9.6 The manipulator crane used for movement of CEAs or fuel assemblies within the reactor pressure vessel shall be demonstrated OPERABLE within 72 hours prior to the start of such operations by performing a joad test of at least pounds and demonstrating an automatic load cut off when the crane load exceeds _ pounds. 
REFUELING OPERATIONS

3/4.9.7 CRANE TRAVEL - SPENT FUEL STORAGE POOL BUILDING

LIMITING CONDITION FOR OPERATION

3.9.7 Loads in excess of pounds shall be prohibited from travel over fuel assemblies in the storage pool.

APPLICABILITY: With fuel assemblies in the storage pool.

ACTION:

With the requirements of the above specification not satisfied, place the crane load in a safe condition. The provisions of Specification 3.0.3 are not applicable.

4.9.7 Crane interlocks and physical stops which prevent crane travel with loads in excess of OPERABLE within 7 days prior to crane use and at least once per 7 days thereafter during crane operation. 
REFUELING OPERATIONS

3/4.9.8 COOLANT CIRCULATION

LIMITING CONDITION FOR OPERATION

3.9.8 At least one shutdown cooling loop shall be in operation.

APPLICABILITY: MODE 6.

ACTION:

a. With less than one shutdown cooling loop in operation, except as provided in b. below, suspend all operations involving an increase in the reactor decay heat load or a reduction in boron concentration of the Reactor Coolant System. Close all containment penetrations providing direct access from the containment atmosphere to the outside atmosphere within 4 hours.

b. The shutdown cooling loop may be removed from operation for up to 1 hour per 8 hour period during the performance of CORE ALTERATIONS in the vicinity of the reactor pressure vessel hot legs.

c. The provisions of Specification 3.0.3 are not applicable.

4.9.8 A shutdown cooling loop shall be determined to be in operation and circulating reactor coolant at a flow rate of greater than or equal to (3000) gpm at least once per 24 hours. 


\section{REFUELING OPERATIONS}

3/4.9.9 CONTAINMENT PURGE VALVE ISOLATION SYSTEM

3.9.9 The containment purge valve isolation system shall be OPERABLE. APPLICABILITY: During CORE ALTERATIONS or movement of irradiated fuel within the containment.

ACTION:

With the containment purge valve isolation system inoperable, close each of the containment purge penetrations providing direct access from the containment atmosphere to the outside atmosphere. The provisions of Specifications 3.0.3 and 3.0.4 are not applicable.

4.9.9 The containment purge valve isolation system shall be demonstrated OPERABLE within 72 hours prior to the start of and at least once per 7 days during CORE ALTERATIONS by verifying that containment purge valve isolation occurs on manual initiation and on a high radiation test signal from each of the containment radiation monitoring instrumentation channels. 
3/4.9.10 WATER LEVEL - REACTOR VESSEL

3.9.10 At least 23 feet of water shall be maintained over the top of irradiated fuel assemblies seated within the reactor pressure vessel.

APPLICABILITY: During movement of fuel assemblies or CEAs within the reactor pressure vessel while in MODE 6 .

ACTION:

With the requirements of the above specification not satisfied, suspend all operations involving movement of fuel assemblies or CEAs within the pressure vessel. The provisions of Specification 3.0.3 are not applicable.

4.9.10 The water level shall be determined to be at least its minimum required depth within 2 hours prior to the start of and at least once per 24 hours thereafter during movement of fuel assemblies or CEAs. 
REFUELING OPERATIONS

3/4.9.11 WATER LEVEL-STORAGE POOL

LIMITING CONDITION FOR OPERATION

3.9.11 At least 23 feet of water shall be maintained over the top of irradiated fuel assemblies seated in the storage racks.

APPLICABILITY: Whenever irradiated fuel assemblies are in the storage pool.

ACTION:

With the requirement of the specification not satisfied, suspend all movement of fuel assemblies and crane operations with loads in the fuel storage areas and restore the water level to within its limit within 4 hours. The provisions of Specification 3.0.3 are not applicable.

SURVEILLANCE REQUIREMENTS

4.9.11 The water level in the storage pool shall be determined to be at least its minimum required depth at least once per 7 days when irradiated fuel assemblies are in the fuel storage pool. 
REFUELING OPERATIONS

3/4.9.12 STORAGE POOL AIR CLEANUP SYSTEM

LIMITING CONDITION FOR OPERATION

3.9.12 Two independent fuel storage pool air cleanup systems shall be OPERABLE. APPLICABILITY: Whenever irradiated fuel is in the storage pool.

ACTION:

a. With one fuel storage pool air cleanup system inoperable, fuel movement within the storage pool or crane operation with loads over the storage pool may proceed provided the OPERABLE fuel storage pool air cleanup system is in operation and discharging through at least one train of HEPA filters and charcoal adsorbers.

b. With no fuel storage pool air cleanup system OPERABLE, suspend all operations involving movement of fuel within the storage pool or crane operation with loads over the storage pool until at least one spent fuel storage pool air cleanup system is restored to OPERABLE status.

c. The provisions of Specifications 3.0.3 and 3.0.4 are not applicable.

SURVEILLANCE REQUIREMENTS

4.9.12 The above required spent fuel storage pool air cleanup systems shall be demonstrated OPERABLE:

a. At least once per 31 days on a STAGGERED TEST BASIS by initiating, from the control room, flow through the HEPA filters and charcoal adsorbers and verifying that the system operates for at least 10 hours with the heaters on.

b. At least once per 18 months or (1) after any structural maintenance on the HEPA filter or charcoal adsorber housings, or (2) following painting, fire or chemical release in any ventilation zone communicating with the system by: 
REFUELING OPERATIONS

SURVEILLANCE REQUIREMENTS (Continued)

1. Verifying that with the system operating at a flow rate of cfm $\pm 10 \%$ and exhausting through the HEPA filters and charcoal adsorbers, the total bypass flow of the system to the facility vent, including leakage through the system diverting valves, is less than or equal to $1 \%$ when the system is tested by admitting cold DOP at the system intake. (For systems with diverting valves.)

2. Verifying that the cleanup system satisfies the in-place testing acceptance criteria and uses the test procedures of Regulatory Positions C.5.a, C.5.c and C.5.d of Regulatory Guide 1.52, Revision 2, March 1978, and the system flow rate is $\mathrm{cfm} \pm 10 \%$.

3. Verifying within 31 days after removal that a laboratory analys is of a representative carbon sample obtained in accordance with Regulatory Position C.6.b of Regulatory Guide 1.52, Revision 2, March 1978, meets the laboratory testing criteria of Regulatory Position C.6.a of Regulatory Guide 1.52, Revision 2. March 1978.

4. Verifying a system flow rate of cfm $+10 \%$ during system operation when tested in accordance with ANSI N510-1975.

c. After every 720 hours of charcoal adsorber operation by verifying within 31 days after removal that a laboratory analys is of a representative carbon sample obtained in accordance with Regulatory Position C.6.b of Regulatory Guide 1.52, Revision 2, March 1978, meets the laboratory testing criteria of Regulatory Position C. 6 .a of Regulatory Guide 1.52, Revision 2, March 1978.

d. At least once per 18 months by:

1. Verifying that the pressure drop across the combined HEPA filters and charcoal adsorber banks is less than (6) inches Water Gauge while operating the system at a flow rate of $\mathrm{cfm} \pm 10 \%$.

2. Verifying that on a high radiation test signal, the system automatically starts (unless already operating) and directs its exhaust flow through the HEPA filters and charcoal adsorber banks. 
3. Verifying that the system maintains the spent fuel storage pool area at a negative pressure of greater than or equal to (1/4) inches Water Gauge relative to the outside atmosphere during system operation.

4. Verifying that the filter cooling bypass valves can be manually opened.

5. Verifying that the heaters dissipate tested in accordance with ANSI N510-1975.

\pm kw when

e. After each complete or partial replacement of a HEPA filter bank by verifying that the HEPA filter banks remove greater than or equal to (99.95)\%* of the DOP when they are tested in-place in accordance with ANSI N510-1975 while operating the system at a flow rate of $\mathrm{cfm} \pm 10 \%$.

f. After each complete or partial replacement of a charcoal adsorber bank by verifying that the charcoal adsorbers remove greater than or equal to $99.95 \%$ of a halogenated hydrocarbon refrigerant test gas when they are tested in-place in accordance with ANSI N510-1975 while operating the system at a flow rate of _ cfm $\pm 10 \%$.

*99.95\% applicable when a filter efficiency of $99 \%$, is assumed in the safety analyses; $99 \%$ when a filter efficiency of $90 \%$ is assumed. 


\section{3/4.10 SPECIAL TEST EXCEPTIONS}

3/4.10.1 SHUTDOWN MARGIN

3.10.1 The SHUTDOWN MARGIN requirement of Specification 3.1.1.1 may be suspended for measurement of CEA worth and shutdown margin provided reactivity equivalent to at least the highest estimated CEA worth is available for trip insertion from OPERABLE CEA(s).

APPLICABILITY: MNDE 2.

ACTION:

a. With any full length CEA not fully inserted and with less than the above reactivity equivalent available for trip insertion, immediately initiate and continue boration at greater or equal to (40) gpm of (1731) ppm boric acid solution or its equivalent until the SHUTDOWN MARGIN required by Specification 3.1.1.1 is restored.

b. With all full length CEAs inserted and the reactor subcritical by less than the above reactivity equivalent, immediately initiate and continue boration at greater than or equal to (40) $\mathrm{gpm}$ of (1731) $\mathrm{ppm}$ boric acid solution or its equivalent until the SHUTDOWN MARGIN required by Specification 3.1.1.1 is restored.

SIJRVEILLANCE REOUIREMENTS

4.10.1.1 The position of each full length and part length CEA required either partialiy or fully withdrawn shall be determined at least once per 2 hours.

4.10.1.2 Each CEA not fully inserted shall be demonstrated capable of full insertion when tripped from at least the $50 \%$ withdrawn position within 24 hours prior to reducing the SHUTDOWN MARGIN to less than the limits of Specification 3.1.1.1. 
SPECIAL TEST EXCEPTIONS

3/4.10.2 GROIP HEIGHT, INSERTINN AND POWER DISTRIBUTION LIMITS

LIMITING CONDITION FOR OPERATION

3.10.2 The group heiaht, insertion and power distrihution limits of Specifications $(3.1 .1 .3),(3.1 .3 .1),(3.1 .3 .5),(3.1 .3 .6),(3.1 .3 .8),(3.2 .2),(3.2 .3)$ and (the Minimum Channels OPERABLE requirement of Functional IIn it 15 of Tahle 3.3-1) may be suspended during the performance of PHYSICS TESTS provided:

a. The THEPMAL POWER is restricted to the test nower plateau which shall not exceed (85)\% of RATED THERMAL POWER, and

b. The limits of Specification (3.2.1) are maintained and determined as specified in Specification 4.10.2.2 below.

APPLICARILITY: MNDES 1 and 2.

ACTION:

With any of the limits of Specification (3.2.1) heing exceeded while the requirements of Specifications $(3.1 .1 .3),(3.1 .3 .1),(3.1 .3 .5),(3.1 .3 .6)$, $(3.1 .3 .8),(3.2 .2),(3.2 .3)$ and (the Minimum Channels OPERARLE reauirement of Functional Unit 15 of Table 3.3-1) are suspended, either:

a. Peduce THEPMAL POWFR sufficiently to satisfy the reauirements of Specification $(3.2 .1)$, or

b. Re in HOT STANDBY wthin 6 hours.

SIIRVEILLANCE REOUIREMENTS

4.10.2.1 The THERMAL POWFR shall he determined at least once per hour during PHYSICS TESTS in which the reauirements of Specifications (3.1.1.3), (3.1.3.1), $(3.1 .3 .5),(3.1 .3 .6),(3.1 .3 .8),(3.2 .2),(3.2 .3)$ or (the Minimum Channels OPEPABLE requirement of Functional Unit 15 of Table 3.3-1) are suspended and shall be verified to be within the test power plateau.

4.10.2.2 The linear heat rate shall be determined to be within the limits of Specification (3.2.1) by monitoring it continuously with the Incore netector Monitoring System pursuant to the requirements of Specifications (4.2.1.3) and (3.3.3.2) during PHYSICS TESTS ahove $5 \%$ of RATFD THERMAL POWER in which the requirements of Specifications $(3.1 .1 .3),(3.1 .3 .1),(3.1 .3 .5),(3.1 .3 .6)$, $(3.1 .3 .8),(3.2 .2),(3.2 .3)$ or (the Minimum Channels OPERABLE requirement of Functional Unit 15 of Table 3.3-1) are suspended.
CE-STS
$3 / 4 \quad 10-2$ 
SPECIAL TEST EXCEPTIONS

3/4.10.3 REACTOR COOLANT LOOPS

LIMITING CONDITION FOP. OPERATION

3.10.3 The limitations of Specification (3.4.1) and (noted requirements of Table 3.3-1) may be suspended during the performance of startup and PHYSICS TESTS, provided:

a. The THEPMAL POWER does not exceed $5 \%$ of RATED THERMAL POHER, and

b. The reactor trip setpoints of the OPERABLE power level channels are set at less than or equal to (20)\% of RATEN THERMAL POIJFR.

APPLICARILITY: During startup and PHYSICS TESTS.

ACTION:

With the THERMAL POWER greater than $5 \%$ of RATED THERMAL POWER, immediately trip the reactor.

SURVEILLANCE REOUIREMENTS

4.10.3.1 The THEPMAL POWER shall he determined to he less than or eoual to $5 \%$ of RATED THERMAL POWER at least once per hour during startup and PHYSICS TESTS.

4.10.3.2 Each wide range logarithmic and power level neutron flux monitoring channel shall be suhjected to a CHANNEL FUNCTIONAL TEST within 12 hours prior to initiating startup or PHYSICS TESTS. 
SPECIAL TEST EXCEPTIONS

3/4.10.4 CENTER CEA MISALIGNMENT

3.10.4 The requirements of Specifications (3.1.3.1) and (3.1.3.7) may be suspended during the performance of PHYSICS TESTS to determine the isothermal temperature coefficient, moderator temperature coefficient and power coefficient provided:

a. Only the center CEA (CEA \#1) is misaligned, and

b. The limits of Specification (3.2.1) are maintained and determined as specified in Specification 4.10 .4 .2 below.

APPLICABILITY: MODES 1 and 2.

ACTION:

With any of the limits of Specification (3.2.1) heing exceeded while the requirements of Specifications $(3.1 .3 .1)$ and $(3.1 .3 .7)$ are suspended, either:

a. Reduce THERMAL POWER sufficientiy to satisfy the requirements of Specification $(3.2 .1)$, or

b. Be in HOT STANDBY within 6 hours.

SURVEILLANCE REQUIREMENTS

4.10.4.1 The THERMAL POWER shall be determined at least once per hour during PHYSICS TESTS in which the requirements of Specifications (3.1.3.1) and/or (3.1.3.7) are suspended and shall be verified to be within the test power plateau.

4.10.4.2 The linear heat rate shall be determined to be within the limits of Specification (3.2.1) by monitoring it continuousiy with the Incore Detector Monitoring System pursuant to the requirements of Specification (3.3.3.2) during PHYSICS TESTS above $5 \%$ of RATED THERMAL POWER in which the requirements of Specifications $(3.1 .3 .1)$ and/or $(3.1 .3 .7)$ are suspended. 


\section{BASES}

FOR

SECTIONS 3.0 AND 4.0

LIMITING CONDITIONS FOR OPERATION

AND

SURVEILLANCE REQUIREMENTS 


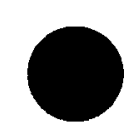

○

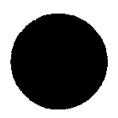


The summary statements contained in this section provide the bases of the specifications of Sections 3.0 and 4.0 and are not considered a part of these technical specifications as provided in 10 CFR 50.36. 
○

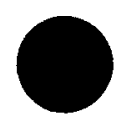

• 


\section{$3 / 4.0 \quad$ APPLICABILITY}

BASES

The specifications of this section provide the general requirements applicable to each of the Limiting Conditions for Operation and Surveillance Requirements within Section 3/4.

3.0.1 This specification defines the applicability of each specification in terms of defined OPERATIONAL MODES or other specified conditions and is provided to delineate specifically when each specification is applicable.

3.0.2 This specification defines those conditions necessary to constitute compliance with the terms of an individual Limiting Condition for Operation and associated ACTION requirement.

3.0.3 This specification delineates the ACTION to be taken for circumstances not directly provided for in the ACTION statements and whose occurrence would violate the intent of the specification. For example, Specification 3.5.1 requires each Reactor Coolant System safety injection tank to be OPERABLE and provides explicit ACTION requirements if one safety injection tank is inoperable. Under the terms of Specification 3.0.3, if more than one safety injection tank is inoperable, the Unit is required to be in at least HOT STANDBY within 1 hour and in at least HOT SHUTDOWN within the following 6 hours. As a further example, Specification 3.6.2.1 requires two Containment Spray Systems to be OPERABLE and provides explicit ACTION requirements if one spray system is inoperable. Under the terms of Specification 3.0.3, if both of the required Containment Spray Systems are inoperable, the unit is required to be in at least HOT STANDBY within 1 hour, in at least HOT SHUTDOWN within the following 6 hours and in COLD SHUTDOWN in the next 24 hours.

3.0.4 This specification provides that entry into an OPERATIONAL MODE or other specified applicability condition must be made with (a) the full complement of required systems, equipment or components OPERABLE and (b) all other parameters as specified in the Limiting Conditions for Operation being met without regard for allowable deviations and out of service provisions contained in the ACTION statements.

The intent of this provision is to insure that facility operation is not initiated with either required equipment or systems inoperable or other specified limits being exceeded. 
Exceptions to this provision have been provided for a limited number of specifications when startup with inoperable equipment would not affect plant safety. These exceptions are stated in the ACTION statements of the appropriate specifications.

4.0.1 This specification provides that surveillance activities necessary to insure the Limiting Conditions for Operation are met and will be performed during the OPERATIONAL MODES or other conditions for which the Limiting Conditions for Operation are applicable. Provisions for additional surveillance activities to be performed without regard to the applicable OPERATIONAL MODES or other conditions are provided in the individual Surveillance Requirements. Surveillance Requirements for Special Test Exceptions need only be performed when the Special Test Exception is being utilized as an exception to an individual Specification.

4.0.2 The provisions of this specification provide allowable tolerances for performing surveillance activities beyond those specified in the nominal surveillance interval. These tolerances are necessary to provide operational flexibility because of scheduling and performance considerations. The phrase "at least" associated with a surveillance frequency does not negate this allowable tolerance value and permits the performance of more frequent surveillance activities.

The tolerance values, taken either individually or consecutively over 3 test intervals, are sufficiently restrictive to ensure that the reliability associated with the surveillance activity is not significantly degraded beyond that obtained from the nominal specified interval.

4.0.3 The provisions of this specification set forth the criteria for determination of compliance with the OPERABILITY requirements of the Limiting Conditions for Operation. Under this criteria, equipment, systems or components are assumed to be OPERABLE if the associated surveillance activities have been satisfactorily performed within the specified time interval. Nothing in this provision is to be construed as defining equipment, systems or components OPERABLE, when such items are found or known to be inoperable although still meeting the Surveillance Requirements.

4.0.4 This specification ensures that the surveillance activities associated with a Limiting Condition for Operation have been performed within the specified time interval prior to entry into an OPERATIONAL MODE or other applicable condition. The intent of this provision is to ensure that surveillance activities have been satisfactorily demonstrated on a current basis as required to meet the OPERABILITY requirements of the Limiting Condition for Operation. 
Under the terms of this specification, for example, during initial plant startup or following extended plant outages, the applicable surveillance activities must be performed within the stated surveillance interval prior to placing or returning the system or equipment into OPERABLE status.

4.0.5 This specification ensures that inservice inspection of ASME Code Class 1,2 and 3 components and inservice testing of ASME Code Class 1, 2 and 3 pumps and valves will be performed in accordance with a periodically updated version of Section XI of the ASME Boiler and Pressure Vessel Code and Addenda as required by 10 CFR 50.55a. Relief from any of the above requirements has been provided in writing by the Commission and is not a part of these technical specifications.

This specification includes a clarification of the frequencies for performing the inservice inspection and testing activities required by Section XI of the ASME Boiler and Pressure Vessel Code and applicable Addenda. This clarification is provided to ensure consistency in surveillance intervals thoughout these Technical Specifications and to remove any ambiguities relative to the frequencies for performing the required inservice inspection and testing activities.

Under the terms of this specification, the more restrictive requirements of the Technical Specifications take precedence over the ASME Boiler and Pressure Vessel Code and applicable Addenda. For example, the requirements of Specification 4.0.4 to perform surveillance activities prior to entry into an OPERATIONAL MODE or other specified applicability condition takes precedence over the ASME Boiler and Pressure Vessel Code provision which allows pumps to be tested up to one week after return to normal operation. And for example, the Technical Specification definition of OPERABLE does not grant a grace period before a device that is not capable of performing its specified function is declared inoperable and takes precedence over the ASME Boiler and Pressure Vessel Code provision which allows a valve to be incapable of performing its specified function for up to 24 hours before being declared inoderable. 
3/4.1 REACTIVITY CONTROL SYSTEMS

BASES

3/4.1.1 BORATION CONTROL

3/4.1.1.1 and 3/4.1.1.2 SHUTDOWN MARGIN

A sufficient SHUTDOWN MARGIN ensures that 1) the reactor can be made subcritical from all operating conditions, 2) the reactivity transients associated with postulated accident conditions are controllable within acceptable limits, and 3) the reactor will be maintained sufficiently subcritical to preclude inadvertent criticality in the shutdown condition.

SHUTDOWN MARGIN requirements vary throughout core life as a function of fuel depletion, RCS boron concentration, and RCS $T_{\text {avg }}$. The most restrictive condition occurs at EOL, with $T_{\text {avg }}$ at no load operating temperature, and is associated with a postulated steam line break accident and resulting uncontrolled RCS cooldown. In the analys is of this accident, a minimum SHUTDOWN MARGIN of $(5.0) \%$ delta $\mathrm{k} / \mathrm{k}$ is required to control the reactivity transient. Accordingly, the SHUTDOWN MARGIN requirement is based upon this limiting condition and is consistent with FSAR safety analysis assumptions. With $T_{\text {avg }}$ less than or equal to $200^{\circ} \mathrm{F}$, the reactivity transients resulting from any postulated accident are minimal and a $1 \%$ delta $\mathrm{k} / \mathrm{k}$ shutdown margin provides adequate protection.

\section{3/4.1.1.3 MODERATOR TEMPERATURE COEFFICIENT (MTC)}

The limitations on MTC are provided to ensure that the assumptions used in the accident and transient analys is remain valid through each fuel cycle. The surveillance requirements for measurement of the MTC during each fuel cycle are adequate to confirm the MTC value since this coefficient changes slowly due principally to the reduction in RCS boron concentration associated with fuel burnup. The confirmation that the measured MTC value is within its limit provides assurances that the coefficient will be maintained within acceptable values throughout each fuel cycle. 
REACTIVITY CONTROL SYSTEMS

BASES

\section{3/4.1.1.4 MINIMUM TEMPERATURE FOR CRITICALITY}

This specification ensures that the reactor will not be made critical with the Reactor Coolant System average temperature less than $(525)^{\circ} \mathrm{F}$. This limitation is required to ensure 1) the moderator temperature coefficient is within its analyzed temperature range, 2) the protective instrumentation is within its normal operating range, 3) the pressurizer is capable of being in an OPERABLE status with a steam bubble, and 4) the reactor pressure vessel is above its minimum RT ${ }_{\text {NDT }}$ temperature.

\section{3/4.1.2 BORATION SYSTEMS}

The boron injection system ensures that negative reactivity control is available during each mode of facility operation. The components required to perform this function include 1) borated water sources, 2) charging pumps, 3) separate flow paths, 4) boric acid makeup pumps, 5) associated heat tracing systems, and 6) an emergency power supply from OPERABLE diesel generators.

With the RCS average temperature above $200^{\circ} \mathrm{F}$, a minimum of two separate and redundant boron injection systems are provided to ensure single functional capability in the event an assumed failure renders one of the systems inoperable. Al lowable out-of-service periods ensure that minor component repair or corrective action may be completed without undue risk to overall facility safety from injection system failures during the repair period.

The boration capability of either system is sufficient to provide a SHUTDOWN MARGIN from expected operating conditions of $1.0 \%$ delta $\mathrm{k} / \mathrm{k}$ after xenon decay and cooldown to $200^{\circ} \mathrm{F}$. The maximum expected boration capability requirement occurs at EOL from full power equilibrium xenon conditions and requires boric acid solution from the boric acid makeup tanks in the allowable concentrations and volumes of Specification 3.1.2.8 or $(40,200)$ gallons of (1731) ppm borated water from the refueling water tank.

With the RCS temperature below $200^{\circ} \mathrm{F}$ one injection system is acceptable without single failure consideration on the basis of the stable reactivity condition of the reactor and the additional restrictions prohibiting CORE ALTERATIONS and positive reactivity changes in the event the single injection system becomes inoperable.

The boron capability required below $200^{\circ} \mathrm{F}$ is based upon providing a $1 \%$ delta $\mathrm{k} / \mathrm{K}$ SHUTDOWN MARGIN after xenon decay and cooldown from $200^{\circ} \mathrm{F}$ to $140^{\circ} \mathrm{F}$. This condition requires either $(4,700)$ galions of (1731) ppm borated water from the refueling water tank or boric acid solution from the boric acid makeup tanks in accordance with the requirements of Specification 3.1.2.7. 
REACTIVITY CONTROL SYSTEMS

BASES

BORATION SYSTEMS (Continued)

The contained water volume limits includes allowance for water not available because of discharge line location and other physical characteristics.

The OPERABILITY of one boron injection system during REFUELING ensures that this system is available for reactivity control while in MODE 6 .

The limits on contained water volume and boron concentration of the RWT also ensure a $\mathrm{pH}$ value of between (8.9) and (11.0) for the solution recirculated within containment after a LOCA. This pH band minimizes the evolution of iodine and minimizes the effect of chloride and caustic stress corrosion on mechanical systems and components.

\section{3/4.1.3 MOVABLE CONTROL ASSEMBLIES}

The specifications of this section ensure that (1) acceptable power distribution limits are maintained, (2) the minimum SHUTDOWN MARGIN is maintained, and (3) the potential effects of CEA misalignments are limited to acceptable levels.

The ACTION statements which permit limited variations from the basic requirements are accompanied by additional restrictions which ensure that the original design criteria are met.

The ACTION statements applicable to a stuck or untrippable CEA to two or more inoperable CEAs and to a large misalignment (greater than or equal to 19 inches) of two or more CEAs, require a prompt shutdown of the reactor since either of these conditions may be indicative of a possible loss of mechanical functional capability of the CEAs and in the event of a stuck or untrippable CEA, the loss of SHUTDOWN MARGIN.

For small misalignments (less than 19 inches) of the CEAs, there is 1) a small effect on the time dependent long term power distributions relative to those used in generating LCOs and LSSS setpoints, 2) a small effect on the available SHUTDOWN MARGIN, and 3) a small effect on the ejected CEA worth used in the safety analysis. Therefore, the ACTION statement associated with small misalignments of CEAs permits a one hour time interval during which attempts may be made to restore the CEA to within its alignment requirements. The one hour time limit is sufficient to (1) identify causes of a misaligned CEA,

(2) take appropriate corrective action to realign the CEAs and (3) minimize the effects of xenon redistribution. 
MOVABLE CONTROL ASSEMBLIES (Continued)

The CPCs provide protection to the core in the event of a large misalignment (greater than or equal to 19 inches) of a CEA by applying appropriate penalty factors to the calculation to account for the misaligned CEA. However, this misalignment would cause distortion of the core power distribution. This distribution may, in turn, have a significant effect on 1) the available SHUTDOWN MARGIN, 2) the time dependent long term power distributions relative to those used in generating LCOs and LSSS setpoints, and 3) the ejected CEA worth used in the safety analysis. Therefore, the ACTION statement associated with the large misalignment of a CEA requires a prompt realignment of the misaligned CEA.

The ACTION statements applicable to misaligned or inoperable CEAs include requirements to align the OPERABLE CEAs in a given group with the inoperable CEA. Conformance with these alignment requirements bring the core, within a short period of time, to a configuration consistent with that assumed in generating LCO and LSSS setpoints. However, extended operation with CEAs significantly inserted in the core may lead to perturbations in 1) local burnup, 2) peaking factors and 3 ) available shutdown margin which are more adverse than the conditions assumed to exist in the safety analyses and LCO and LSSS setpoints determination. Therefore, time limits have been imposed on operation with inoperable CEAs to preclude such adverse conditions from developing.

Operability of at least two CEA position indicator channels is required to determine CEA positions and thereby ensure compliance with the CEA alignment and insertion limits. The CEA "Full In" and "Full Out" limits provide an additional independent means for determining the CEA positions when the CEAs are at either their fuliy inserted or fully withdrawn positions. Therefore, the ACTION statements applicable to inoperable CEA position indicators permit continued operations when the positions of CEAs with inoperable position indicators can be verified by the "Full In" or "Full Out" 1 imits.

CEA positions and OPERABILITY of the CEA position indicators are required to be verified on a nominal basis of once per 12 hours with more frequent verifications required if an automatic monitoring channel is inoperable. These verification frequencies are adequate for assuring that the applicable LCO's are satisfied.

The maximum CEA drop time restriction is consistent with the assumed CEA drop time used in the safety analyses. Measurement with $T_{\text {avg }}$ greater than or equal to $(525)^{\circ} \mathrm{F}$ and with all reactor coolant pumps operating ensures that the measured drop times will be representative of insertion times experienced during a reactor trip at operating conditions. 
REACTIVITY CONTROL SYSTEMS

PASES

MOVABLE CONTPOL ASSEMRLIES (Continued)

The establishment of LSSS and LCOS reauire that the expected lora and short term behavior of the radial peaking factors be determined. The long term hehavior relates to the variation of the steady state radial peakina factors with core burnup and is affected by the amount of CEA insertion assumed, the portion of a hurnup cycle over which such insertion is assumed and the expected power level variation throughout the cycle. The short term hehavior relates to transient perturbations to the steady-state radial peaks due to radial xenon redistribution. The magnitudes of such perturbations depend upon the expected use of the CEAs during anticipated power reductions and load maneuverino. Analyses are performed based on the expected mode of operation of the NSSSS (hase loaded, or load maneuvering). Analyses are performed based on the expected mode of operation of the NSSS (hase load manelivering, etc.) and from these analyses CEA insertions are determined and a consistent set of radial peaking factors defined. The Lona Term Steady State and Short Term Insertion Limits are determined based upon the assumed mode of operation used in the analyses and provide a means of preserving the assumptioris on CEA insertions used. The limits specified serve to limit the hehavior of the radial peaking factors within the bounds determined from analysis. The actions specified serve to limit the extent of radiai xenon redistrihution effects to those accomodated in the analyses. The Long and Short Term Insertion Limits of Specification 3.1.3.6 are specified for the plant which has been desianed for primarily base ioaded operation hut which has the ability to accomodate a limited amount of load maneuvering.

The Transient Insertion Limits of Specification 3.1.3.6 and the Shutdown C.EA Insertion Limits of Specification 3.1.3.5 ensure that 1) the minimum SHUTDOWN MARGIM is maintained, and 2) the potential effects of a CFA ejection accident are limited to acceptable levels. Long term operation at the Transient Insertion Limits is not permitted since such operation could have effects on the core power distribution which could invalidate assumptions used to determine the behavior of the radial peaking factors.

\section{(ALTERNATE)}

The restriction prohibiting part lenath CEA insertion ensures that adverse power shapes and rapid local power changes which affect INB considerations do not occur as a result of part length CEA insertion during operation. 
○

○

○ 
3/4.2 POWER DISTRIBUTION LIMITS

BASES

\section{3/4.2.1 LINEAR HEAT RATE}

The limitation on linear heat rate ensures that in the event of a LOCA, the peak temperature of the fuel cladding will not exceed $2200^{\circ} \mathrm{F}$.

Either of the two core power distribution monitoring systems, the Core Operating Limit Supervisory System (COLSS) and the Local Power Density channels in the Core Protection Calculators (CPCS), provide adequate monitoring of the core power distribution and are capable of verifying that the linear heat rate does not exceed its its limits. The COLSS performs this function by continuousiy monitoring the core power distribution and calculating a core power operating limit corresponding to the allowable peak linear heat rate. Reactor operation at or below this calculated power level assures that the limits of Figure 3.1-1 are not exceeded.

The COLSS calculated core power and the COLSS calculated core power operating limits based on linear heat rate are continuously monitored and displayed to the operator. A COLSS alarm is annunciated in the event that the core power exceeds the core power operating limit. This provides adequate margin to the linear heat rate operating limit for normal steady state operation. Normal reactor power transients or equipment failures which do not require a reactor trip may result in this core power operating limit being exceeded. In the event this occurs, COLSS alarms will be annunciated. If the event which causes the COLSS limit to be exceeded results in conditions which approach the core safety limits, a reactor trip will be initiated by the Reactor Protective Instrumentation. The COLSS calculation of the linear heat rate limit includes appropriate uncertainty and penalty factors necessary to provide a 95/95 confidence level that the maximum linear heat rate calculated by COLSS is greater than or equal to that existing in the core. To ensure that the design margin to safety is maintained, the COLSS computer program includes an $F$ measurement uncertainty factor of 1.080 , an engineering uncertainty fact $r$ r of 1.03 , a THERMAL POWER measurement uncertainty factor of 1.02 and appropriate uncertainty and penalty factors for flux peaking augmentation and rod bow.

Parameters required to maintain the operating limit power level based on linear heat rate, margin to DNB and total core power are also monitored by the CPCs. Therefore, in the event that the COLSS is not being used, operation within the limits of Figure 3.2-3 can be maintained by utilizing a predetermined local power density margin and a total core power limit in the CPC trip channels. The above listed uncertainty and penalty factors are also included in the CPCs. 


\section{3/4.2.2 RADIAL PEAKING FACTORS}

Limiting the values of the planar radial peaking factors $\left(F_{r}^{C}\right)$ used in the COLSS and CPCS to values equal to or greater than the measured planar radial peaking factors $\left(F_{r}^{m}\right)$ provides assurance that the 1 imits calculated by COLSS and the CPCS remain valid. Data from the incore detectors are used for determining the measured planar radial peaking factors. The periodic surveillance requirements for determining the measured planar radial peaking factors provides assurance that the planar radial peaking factors used in COLSS and the CPCS remain valid throughout the fuel cycle. Determining the measured planar radial peaking factors after each fuel loading prior to exceeding $70 \%$ of RATED THERMAL POWER provides additional assurance that the core was properiy loaded.

\section{3/4.2.3 AZIMUTHAL POWER TILT - $\mathrm{T}_{\mathrm{g}}$}

The limitations on the AZIMUTHAL POWER TILT are provided to ensure that design safety margins are maintained. An AZIMUTHAL POWER TILT greater than 0.10 is not expected and if it should occur, operation is restricted to only those conditions required to identify the cause of the tilt. The tilt is normally calculated by COLSS. The surveillance requirements specified when COLSS is out of service provide an acceptable means of detecting the presence of a steady state tilt. It is necessary to explicitly account for power asymmetries because the radial peaking factors used in the core power distribution calculations are based on an untilted power distribution.

AZIMUTHAL POWER TILT is measured by assuming that the ratio of the power at any core location in the presence of a tilt to the untilted power at the location is of the form:

$$
P_{\text {tilt }} / P_{\text {untilt }}=1+T_{q} g \cos \left(\theta-\theta_{o}\right)
$$

where:

$T_{q}$ is the peak fractional tilt amplitude at the core periphery

$\mathrm{g}$ is the radiai normalizing factor

$\theta$ is the azimuthal core location

$\theta_{0}$ is the azimuthal core location of ridximun tilt 
POWER DISTRIBUTION LIMITS

BASES

AZIMUTHAL POWER TILT - $\mathrm{T}_{\mathrm{g}}$ (Continued)

$\mathrm{P}_{\text {tilt }} / \mathrm{P}_{\text {untilt }}$ is the ratio of the power at a core location in the presence of a tilt to the power at that location with no tilt.

\section{3/4.2.4 DNBR MARGIN}

The limitation on DNBR as a function of AXIAL SHAPE INDEX represents a conservative envelope of operating conditions consistent with the safety analysis assumptions and which have been analytically demonstrated adequate to maintain an acceptable minimum DNBR throughout all anticipated operational occurrences, of which the loss of flow transient is the most limiting. Operation of the core with a DNBR at or above this limit provides assurance that an acceptable minimum DNBR will be maintained in the event of a loss of flow transient.

Either of the two core power distribution monitoring systems, the Core Operating Limit Supervisory System (COLSS) and the DNBR channels in the Core Protection Calculators (CPCS), provide adequate monitoring of the core power distribution and are capable of verifying that the DNBR does not violate its limits. The COLSS performs this function by continuously monitoring the core power distribution and calculating a core operating limit corresponding to the allowable minimum DNBR. Reactor operation at or below this calculated power level assures that the limits of Figure 3.2-2 are not violated. The COLSS calculation of core power operating limit based on DNBR includes appropriate uncertainty and penalty factors necessary to provide a 95/95 confidence level that the core power at which a DNBR of less than 1.30 could occur, as calculated by COLSS, is less than or equal to that which would actually be required in the core. To ensure that the design margin to safety is maintained, the COLSS computer program includes an $F$ measurement uncertainty factor of 1.080 , an engineering uncertainty factor of 1.03 , a THERMAL POWER measurement uncertainty factor of 1.02 and appropriate uncertainty and penalty factors for flux peaking augmentation and rod bow.

Parameters required to maintain the margin to DNB and total core power are also monitored by the CPCs. Therefore, in the event that the COLSS is not being used, operation within the limits of Figure 3.2-3 can be maintained by utilizing a predetermined DNBR as a function of AXIAL SHAPE INDEX and by monitoring the CPC trip channels. The above listed uncertainty and penalty factors are also included in the CPC. 


\section{POWER DISTRIBUTION LIMITS}

\section{BASES}

\section{3/4.2.5 RCS FLOW RATE}

This specification is provided to ensure that the actual RCS total flow rate is maintained at or above the minimum value used in the LOCA safety analyses.

\section{3/4.2.6 CORE AVERAGE COOLANT TEMPERATURE}

This specification is provided to ensure that the assumptions used for the initial conditions of the LOCA safety analyses remain valid. 
$3 / 4.3$ INSTRUMENATION

BASES

\section{3/4.3.1 and 3/4.3.2 REACTOR PROTECTIVE AND ENGINEERED SAFETY FEATURES (ESF)} INSTRUMENTATION

The OPERABILITY of the reactor protective and ESF instrumentation systems and bypasses ensure that 1) the associated ESF action and/or reactor trip will be initiated when the parameter monitored by each channel or combination thereof reaches its setpoint, 2) the specified coincidence logic is maintained, 3) sufficient redundancy is maintained to permit a channel to be out of service for testing or maintenance, and 4) sufficient system functional capability is available for protective and ESF purposes from diverse parameters.

The OPERABILITY of these systems is required to provide the overall reliability, redundancy and diversity assumed available in the facility design for the protection and mitigation of accident and transient conditions. The integrated operation of each of these systems is consistent with the assumptions used in the accident analyses.

The surveillance requirements specified for these systems ensure that the overall system functional capability is maintained comparable to the original design standards. The periodic surveillance tests performed at the minimum frequencies are sufficient to demonstrate this capability.

The measurement of response time at the specified frequencies provides assurance that the protective and ESF action function associated with each channel is completed within the time limit assumed in the accident analyses. No credit was taken in the analyses for those channels with response times indicated as not applicable.

Response time may be demonstrated by any series of sequential, overlapping or total channel test measurements provided that such tests demonstrate the total channel response time as defined. Sensor response time verification may be demonstrated by either 1) in place, onsite or offsite test measurements or 2) utilizing replacement sensors with certified response times.

\section{3/4.3.3 MONITORING INSTRUMENTATION}

\section{3/4.3.3.1 RADIATION MONITORING INSTRUMENTATION}

The OPERABILITY of the radiation monitoring channels ensures that 1) the radiation levels are continually measured in the areas served by the individual channels and 2) the alarm or automatic action is initiated when the radiation level trip setpoint is exceeded. 
INSTRUMENTATION

BASES

\section{3/4.3.3.2 INCORE DETECTORS}

The OPERABILITY of the incore detectors with the specified minimum complement of equipment ensures that the measurements obtained from use of this system accurately represent the spatial neutron flux distribution of the reactor core.

\section{3/4.3.3.3 SEISMIC INSTRUMENTATION}

The OPERABILITY of the seismic instrumentation ensures that sufficient capability is available to promptly determine the magnitude of a seismic event and evaluate the response of those features important to safety. This capability is required to permit comparison of the measured response to that used in the design basis for the facility to determine if plant shutdown is required pursuant to Appendix " $A$ " of 10 CFR Part 100. The instrumentation is consistent with the recommendations or Regulatory Guide 1.12, "Instrumentation for Earthquakes," Apri1 1974.

\section{3/4.3.3.4. METEOROLOGICAL INSTRUMENTATION}

The OPERABILITY of the meteorological instrumentation ensures that sufficient meteorological data is available for estimating potential radiation doses to the public as a result of routine or accidental release of radioactive materials to the atmosphere. This capability is required to evaluate the need for initiating protective measures to protect the health and safety of the public and is consistent with the recommendations of Regulatory Guide 1.23 "Onsite Meteorological Programs," February 1972.

\section{3/4.3.3.5 REMOTE SHUTDOWN INSTRUMENTATION}

The OPERABILITY of the remote shutdown instrumentation ensures that sufficient capability is available to permit shutdown and maintenance of HOT STANDBY of the facility from locations outside of the control room. This capability is required in the event control room habitability is lost and is consistent with General Design Criteria 19 of 10 CFR 50. 
INSTRUMENTATION

BASES

\section{3/4.3.3.6 POST-ACCIDENT INSTRUMENTATION}

The OPERABILITY of the post-accident instrumentation ensures that sufficient information is available on selected plant parameters to monitor and assess these variables following an accident. This capability is consistent with the recommendations of Regulatory Guide 1.97, "Instrumentation for Light-Water-Cooled Nuclear Plants to Assess Plant Conditions During and Following an Accident," December 1975.

\section{3/4.3.3.7 CHLORINE DETECTION SYSTEMS}

The OPERABILITY of the chlorine detection system ensures that sufficient capability is available to promptly detect and initiate protective action in the event of an accidental chlorine release. This capability is required to protect control room personnel and is consistent with the recommendations of Regulatory Guide 1.95, "Protection of Nuclear Power Plant Control Room Operators Against an Accidental Chlorine Release," February 1975.

\section{3/4.3.3.8 FIRE DETECTION INSTRUMENTATION}

OPERABILITY of the fire detection instrumentation ensures that adequate warning capability is available for the prompt detection of fires. This capability is required in order to detect and locate fires in their early stages. Prompt detection of fires will reduce the potential for damage to safety related equipment and is an integral element in the overall facility fire protection program.

In the event that a portion of the fire detection instrumentation is inoperable, the establishment of frequent fire patrols in the affected areas is required to provide detection capability until the inoperable instrumentation is restored to OPERABILITY.

\section{3/4.3.4 TURBINE OVERSPEED PROTECTION}

This specification is provided to ensure that the turbine overspeed protection instrumentation and the turbine speed control valves are OPERABLE and will protect the turbine from excessive overspeed. Protection from turbine excessive overspeed is required since excessive overspeed of the turbine could generate potentially damaging missiles which could impact and damage safety related components, equipment or structures. 
○

-

• 


\section{3/4.4 REACTOR COOLANT SYSTEM}

BASES

\section{3/4.4.1 REACTOR COOLANT LOOPS}

The plant is designed to operate with both reactor coolant loops and associated reactor coolant pumps in operation, and maintain DNBR above 1.30 during all normal operations and anticipated transients. STARTUP and POWER OPERATION may be initiated and may proceed with one or two reactor coolant pumps not in operation after the setpoints for the Power Level-High, Reactor Coolant Flow-Low, and Thermal Margin/Low Pressure trips have been reduced to their specified values. Reducing these trip setpoints ensures that the DNBR wi 11 be maintained above 1.30 during three pump operation and that during two pump operation the core void fraction will be limited to ensure parallel channel flow stability within the core and thereby prevent premature DNB.

A single reactor coolant loop with its steam generator filled above the low level trip setpoint provides sufficient heat removal capability for core cooling while in MODES 2 and 3 ; however, single failure considerations require plant cooldown if component repairs and/or corrective actions cannot be made within the allowable out-of-service time.

The operation of one Reactor Coolant Pump or one shutdown cooling pump provides adequate flow to ensure mixing, prevent stratification and produce gradual reactivity changes during boron concentration reductions in the Reactor coolant system. The reactivity change rate associated with boron reductions wi11, therefore, be within the capability of operator recognition and control.

The restrictions on starting a Reactor Coolant Pump during MODES 4 and 5 with one or more RCS cold legs less than or equal to $(275)^{\circ} \mathrm{F}$ are provided to prevent RCS pressure transients, caused by energy additions from the secondary system, which could exceed the limits of Appendix G to 10 CFR Part 50 . The RCS will be protected against overpressure transients and will not exceed the limits of Appendix $G$ by either (1) restricitng the water volume in the pressurizer and thereby providing a volume for the primary coolant to expand into or (2) by restricting starting of the RCPs to when the secondary water temperature of each steam generator is less than $(46)^{\circ} \mathrm{F}$ above each of the RCS cold leg temperatures.

\section{$3 / 4.4 .2$ and $3 / 4.4 .3$ SAFETY VALVES}

The pressurizer code safety valves operate to prevent the RCS from being pressurized above its Safety Limit of 2750 psia. Each safety valve is designed to relieve lbs per hour of saturated steam at the valve setpoint. The relief capacity of a single safety valve is adequate to relieve any overpressure condition which could occur during shutdown. In the event that no safety valves are OPERABLE, an operating shutdown cooling loop, connected to the RCS, provides overpressure relief capability

CE-STS B B $3 / 4$ 4- 1 


\section{SAFETY VALVES (Continued)}

and will prevent RCS overpressurization. In addition, the Overpressure Protection System provides a diverse means of protection against RCS overpressurization at low temperatures.

During operation, all pressurizer code safety valves must be OPERABLE to prevent the RCS from being pressurized above its safety limit of 2750 psia. The combined relief capacity of these valves is sufficient to limit the Reactor Coolant System pressure to within its Safety Limit of 2750 psia following a complete loss of turbine generator load while operating at RATED THERMAL POWER and assuming no reactor trip until the first Reactor Protective System trip setpoint (Pressurizer Pressure-High) is reached (i.e., no credit is taken for a direct reactor trip on the loss of turbine) and also assuming no operation of the pressurizer power operated relief valve or steam dump valves.

Demonstration of the safety valves' lift settings will occur only during shutdown and will be performed in accordance with the provisions of Section XI of the ASME Boiler and Pressure Vessel Code.

\section{3/4.4.4 PRESSURIZER}

A steam bubble in the pressurizer ensures that the RCS is not a hydraulically solid system and is capable of accommodating pressure surges during operation. The steam bubble also protects the pressurizer code safety valves and power operated relief valve against water relief. The power operated relief valve and steam bubble functions to relieve RCS pressure during all design transients. Operations of the power operated relief valve in conjunction with a reactor trip on a Pressurizer Pressure High signal, minimizes the undersirable opening of the spring loaded pressurizer code safety valves.

\section{3/4.4.5 STEAM GENERATORS}

The Surveillance Requirements for inspection of the steam generator tubes ensure that the structural integrity of this portion of the RCS will be maintained. The program for inservice inspection of steam generator tubes is based on a modification of Regulatory Guide 1.83, Revision 1. Inservice inspection of steam generator tubing is essential in order to maintain surveillance of the conditions of the tubes in the event that there is evidence of mechanical damage or progressive degradation due to design, manufacturing errors, or inservice conditions that lead to corrosion. Inservice inspection of steam generator tubing also provides a means of characterizing the nature and cause of any tube degradation so that corrective measures can be taken.

CE-STS B $3 / 44-2$ 
REACTOR COOLANT SYSTEM

BASES

STEAM GENERATORS (Continued)

The plant is expected to be operated in a manner such that the secondary coolant will be maintained within those chemistry limit.s found to result in negligible corrosion of the steam generator tubes. If the secondary coolant chemistry is not maintained within these limits, localized corrosion may likely result in stress corrosion cracking. The extent of cracking during plant operation would be limited by the limitation of steam generator tube leakage between the primary coolant system and the secondary coolant system (primary-to-secondary leakage $=(0.5) \mathrm{GPM}$ per steam generator). Cracks having a primary-to-secondary leakage less than this limit during operation will have an adequate margin of safety to withstand the loads imposed during normai operation and by postulated accidents. Operating plants have demonstrated that primary-to-secondary leakage of (0.5) GPM per steam generator can readily be detected by radiation monitors of steam generator blowdown. Leakage in excess of this limit will require plant shutdown and an unscheduled inspection, during which the leaking tubes will be located and plugged.

Wastage-type defects are unlikely with proper chemistry treatment of the secondary coolant. However, even if a defect should develop in service, it will be found during scheduied inservice steam generator tube examinations. Plugging will be required for all tubes with imperfections exceeding the plugging limit of (40)\% of the tube nominal wall thickness. Steam generator tube inspections of operating plants have demonstrated the capability to reliably detect degradation that has penetrated $20 \%$ of the original tube wall thickness.

Whenever the results of any steam generator tubing inservice inspection fall into Category $c-3$, these results will be promptiy reported to the Comnission pursuant to Specification 6.9.1 prior the resumption of plant operation. Such cases will be considered by the Commission on a case-by-case basis and may result in a requirement for analys is, laboratory examinations, tests, additional eddy-current inspection, and revision of the Technical Specifications, if necessary.

\section{3/4.4.6 REACTOR COOLANT SYSTEM LEAKAGE}

\section{3/4.4.6.1 LEAKAGE DETECTION SYSTEMS}

The RCS leakage detection systems required by this specification are provided to monitor and detect leakage from the Reactor Coolant Pressure Boundary. These detection systems are consistent with the recommendations of Regulatory Guide 1.45, "Reactor Coolant Pressure Boundary Leakage Detection Systems," May 1973. 
REACTOR COOLANT SYSTEM

BASES

$3 / 4.4 .6 .2$ OPERATIONAL LEAKAGE

Industry experience has shown that while a limited amount of leakage is expected from the RCS, the unidentified portion of this leakage can be reduced to a threshold value of less than 1 GPM. This threshold value is sufficiently low to ensure early detection of additional leakage.

The 10 GPM IDENTIFIED LEAKAGE limitation provides allowances for a limited amount of leakage from known sources whose presence will not interfere with the detection of UNIDENTIFIED LEAKAGE by the leakage detection systems.

The CONTROLLED LEAKAGE limitation restricts operation when the total flow supplied to the reactor coolant pump seals exceeds ( ) GPM with the modulating valve in the supply line fully open at a nominal RCS pressure of (2230) psig. This limitation ensures that in the event of a LOCA, the safety injection flow will not be less than assumed in the accident analyses.

The total steam generator tube leakage limit of 1 GPM for all steam generators ensures that the dosage contribution from the tube leakage will be limited to a small fraction of Part 100 limits in the event of either a steam generator tube rupture or steam line break. The 1 GPM limit is consistent with the assumptions used in the analys is of these accidents. The (0.5) GPM leakage limit per steam generator ensures that steam generator tube integrity is maintained in the event of a main steam line rupture or under LOCA conditions.

PRESSURE BOUNDARY LEAKAGE of any magnitude is unacceptable since it may be indicative of an impending gross failure of the pressure boundary. Therefore, the presence of any PRESSURE BOUNDARY LEAKAGE requires the unit to be prompt7y placed in COLD SHUTDOWN.

\section{3/4.4.7 CHEMISTRY}

The limitations on Reactor Coolant System chemistry ensure that corrosion of the Reactor Coolant System is minimized and reduces the potential for Reactor Coolant System leakage or failure due to stress corrosion. Maintaining the chemistry within the Steady State Limits provides adequate corrosion protection to ensure the structural integrity of the Reactor Coolant System over the life of the plant. The associated effects of exceeding the oxygen, chloride and fluoride limits are time and temperature dependent. Corrosion studies show that operation may be continued with contaminant concentration levels in excess of the Steady State Limits, up to the Transient Limits, for the specified limited time intervals without having a significant effect on the structural integrity of the Reactor Coolant System. The time interval permitting continued operation within the restrictions of the Transient Limits 
REACTOR COOLANT SYSTEM

BASES

CHEMISTRY (Continued)

provides time for taking corrective actions to restore the contaminant concentrations to within the Steady State Limits.

The surveillance requirements provide adequate assurance that concentrations in excess of the limits will be detected in sufficient time to take corrective action.

\section{$3 / 4.4 .8 \quad$ SPECIFIC ACTIVITY}

The limitations on the specific activity of the primary coolant ensure that the resulting 2 hour doses at the site boundary will not exceed an appropriately small fraction of Part 100 limits following a steam generator tube rupture accident in conjunction with an assumed steady state primary-tosecondary steam generator leakage rate of $1.0 \mathrm{GPM}$ and a concurrent loss of offsite electrical power. The values for the limits on specific activity represent limits based upon a parametric evaluation by the NRC of typical site locations. These values are conservative in that specific site parameters of the () site, such as site boundary location and meteorological conditions, were not considered in this evaluation.

The ACTION statement permitting POWER OPERATION to continue for limited time periods with the primary coolant's specific activity greater than 1.0 microcurie/gram DOSE EQUIVALENT I-137, but within the allowable limit shown on Figure 3.4-i, accommodates possible iodine spiking phenomenon which may occur following changes in THERMAL POWER. Operation with specific activity levels exceeding 1.0 microcurie/gram DOSE EQUIVALENT I-131 but within the limits shown on Figure 3.4-1 must be restricted to no more than 800 hours per year (approximately 10 percent of the unit's yearly operating time) since the activity levels allowed by Figure 3.4-1 increase the 2 hour thyroid dose at the site boundary by a factor of up to 20 following a postulated steam generator tube rupture. The reporting of cumulative operating time over 500 hours in any 6 month consecutive period with greater than 1.0 microcurie/gram DOSE EQUIVALENT I-131 will allow sufficient time for Commission evaluation of the circumstances prior to reaching the 800 hour limit.

Reducing $T_{\text {avg }}$ to less than $500^{\circ} \mathrm{F}$ prevents the release of activity should a steam generator ${ }^{2}$ tube rupture since the saturation pressure of the primary coolant is below the lift pressure of the atmospheric steam relief valves. The surveillance requirements provide adequate as surance that excessive specific activity levels in the primary coolant will be detected in sufficient time to take corrective action. Information obtained on iodine spiking will be used to assess the parameters associated with spiking phenomena. A reduction in frequency of isotopic analyses following power changes may be permissible if justified by the data obtained. 


\section{3/4.4.9 PRESSIJRE/TEMPERATURE LIMITS}

A11 components in the Peactor Coolant System are designed to withstand the effects of cyclic loads due to system temperature and pressure changes. These cyclic loads are introduced by normal load transients, reactor trips, and startup and shutdown operations. The various categories of load cycles used for design purposes are provided in Section () of the FSAR. During startup and shutdown, the rates of temperature and pressure changes are limited so that the maximum specified heatup and cooldown rates are consistent with the design assumptions and satisfy the stress 1 imits for cyclic operation.

During heatup, the thermal aradients in the reactor vessel wall produce thermal stresses which vary from compressive at the inner wall to tensile at the outer wall. These thermal induced compressive stresses tend to alleviate the tensile stresses induced by the internal pressure. Therefore, a pressuretemperature curve hased on steady state conditions (i.e., no thermal stresses) represents a lower bound of all similar curves for finite heatup rates when the inner wall of the vessel is treated as the governing location.

The heatup analysis also covers the determination of pressure-temperature limitations for the case in which the outer wall of the vessel becomes the controlling location. The thermal gradients established during heatup produce tensile stresses at the outer wall of the vessel. These stresses are additive to the pressure induced tensile stresses which are already present. The themal induced stresses at the outer wall of the vessel are tensile and are dependent on both the rate of heatup and the time along the heatup ramp; therefore, a lower hound curve similar to that described for the heatup of the inner wall cannot be defined. Consequently, for the cases in which the outer wall of the vessel becomes the stress controlling location, each heatup rate of interest must he analyzed on an individual basis.

The heatup and cooldown limit curves (Figure 3.4-2) are composite curves which were prepared by determining the most conservative case, with either the inside or outside wall controlling, for any heatup or cooldown rates of up to $(75)^{\circ} \mathrm{F}$ per hour. The heatup and cooldown curves were prepared based upon the most limiting value of the predicted adjusted reference temperature at the end of the service period indicated on Figure 3.4-2.

The reactor vessel materials have been tested to determine their initial $\mathrm{RT}_{\text {NDT }}$; the results of these test are shown in Table (B 3/4.4-1). Reactor operation and resultant fast neutron (E greater than 1 Mev) irradiation wi 11 cause an increase in the RT NDT. Therefore, an adjusted reference temperature, based upon the fluence and Copper content of the material in question, can be predicted using Figure (3/4.4-1). The heatup and cooldown limit curves Figures (3.4-2) include predicted adjustments for this shift in RT end of the applicable service period, as well as adjustments for possible errors in the pressure and temperature sensing instruments. 
REACTOR COOLANT SYSTEM

BASES

PRESSURE/TEMPERATURE LIMITS (Continued)

The actual shift in RT periodically during operation by removing and evaluating, in accordance with ASTM E185-73, reactor vessel material irradiation surveillance specimens installed near the inside wall of the reactor vessel in the core area. Since the neutron spectra at the irradiation samples and vessel inside radius are essentially identical, the measured transition shift for a sample can be applied with confidence to the adjacent section of the reactor vessel. The heatup and cooldown curves must be recalculated when the delta RT mined from the surveillance capsule is different from the calculated delta $\mathrm{RT}_{\mathrm{NDT}}$ for the equivalent capsule radiation exposure.

The pressure-temperature limit lines shown on Figure (3.4-2) for reactor criticality and for inservice leak and hydrostatic testing have been provided to assure compliance with the minimum temperature requirements of Appendix $G$ to 10 CFR 50.

The maximum RT materials, with the exception of the reactor pressure vessel, has been determined to be $(50)^{\circ} \mathrm{F}$. The Lowest Service Temperature limit line shown on Figure (3.4-2) is based upon this RT of 1972) of Section III of the ASME Botler and Pressure Vessel Code requires the Lowest Service Temperature to be $\mathrm{RT}_{\text {NDT }}+100^{\circ} \mathrm{F}$ for piping, pumps and valves. Below this temperature, the system pressure must he limited to a maximum of $20 \%$ of the system's hydrostatic test pressure of __ psia.

The number of reactor vessel irradiation surveillance specimens and the frequencies for removing and testing these specimens are provided in Table (4.4-5) to assure compliance with the requirements of Appendix $H$ to $10 \mathrm{CFR}$ Part 50 .

The limitations imposed on the pressurizer heatup and cooldown rates and spray water temperature differential are provided to assure that the pressurizer is operated within the design criteria assumed for the fatigue analysis performed in accordance with the ASME Code requirements.

The OPERABILITY of two PORVS or a RCS vent opening of greater than (1.3) square inches ensures that the RCS will be protected from pressure transients wich could exceed the limits of Appendix $G$ to 10 CFR Part 50 when one or more of the RCS cold legs are less than or equal to $(275)^{\circ} \mathrm{F}$. Either PORV has adequate relieving capability to protect the RCS from overpressurization when the transient is limited to either (1) the start of an idle RCP with the secondary water temperature of the steam generator less than or equal to $(46)^{\circ} \mathrm{F}$ above the RCS cold leg temperatures or (2) the start of a HPSI pump and its injection into a water solid RCS.

CE-STS B $3 / 4$ 4-7 
REACTOR VESSEL TOUGHNESS

Piece No.
Material

Code No.
Drop

Weight

Results
Temperature of

Charpy V-Notch

c 30 @ 50

$f t-1 b-f t-1 b$
Minimum Upper

Shelf $\mathrm{C} v$ energy

for Longitudina?

Direction-ft lb

品

•

$\underset{\oplus}{\oplus}$ 
$\stackrel{P}{1}$
$\stackrel{n}{n}$

$\omega$

i

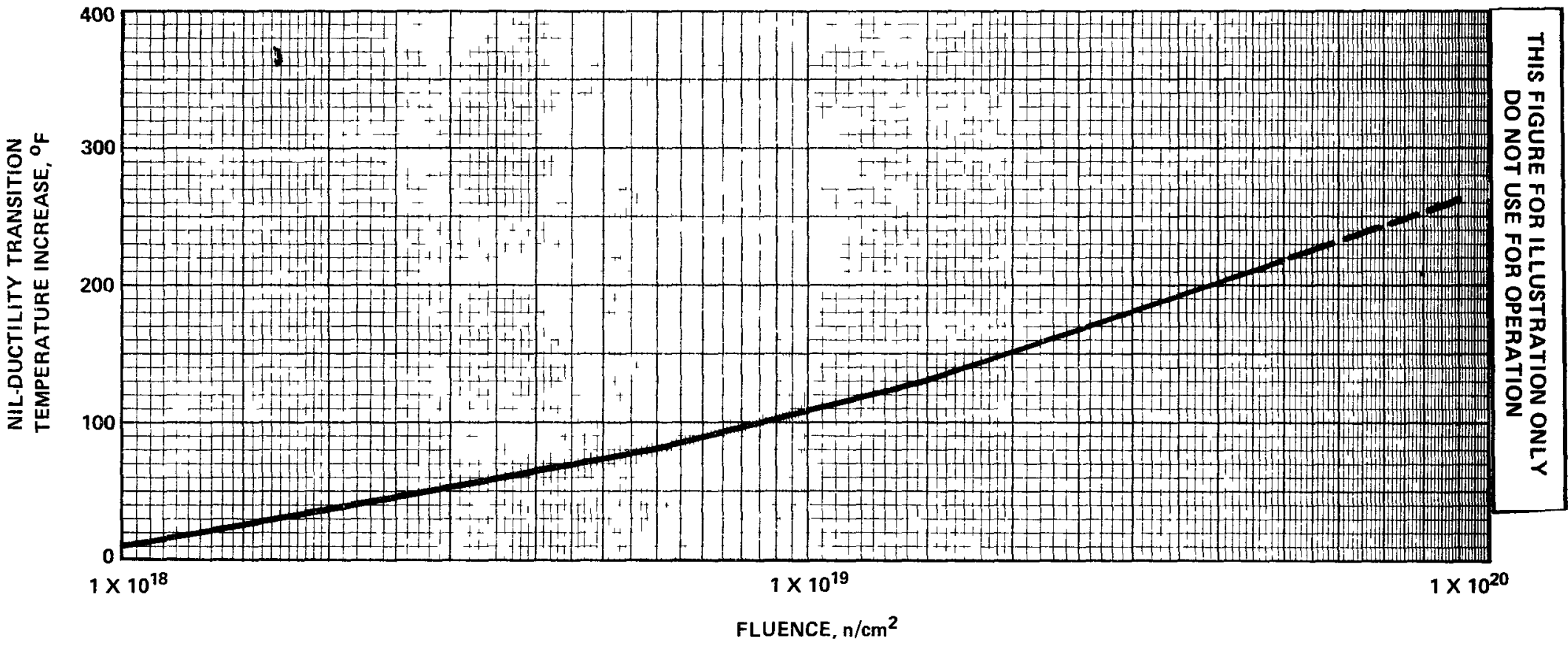

五

Nil Ductility Transition Temperature Increase

as a Function of Fast (E $>1 \mathrm{mev}$ ) Neutron Fluence $\left(550^{\circ} \mathrm{F}\right.$ Irradiation) 
3/4.4.10 STRUCTURAL INTEGRITY

The inservice inspection and testing programs for ASME Code Class 1, 2 and 3 components ensure that the structural integrity and operational readiness of these components will be maintained at an acceptable level throughout the life of the plant. These programs are in accordance with Section XI of the ASME Boiler and Pressure Vessel Code and applicable Addenda as required by 10 CFR Part $50.55 \mathrm{a}(\mathrm{g})$ except where specific written relief has been granted by the Commission pursuant to 10 CFR Part $50.55 \mathrm{a}$ (g) (6) (i).

Components of the reactor coolant system were designed to provide access to permit inservice inspections in accordance with Section XI of the ASME Boiler and Pressure Vessel Code, Edition and Addenda through 


\section{3/4.5 EMERGENCY CORE COOLING SYSTEMS (ECCS)}

\section{BASES}

\section{3/4.5.1 SAFETY INJECTION TANKS}

The OPERABILITY of each of the RCS safety injection tanks ensures that a sufficient volume of borated water will be immediately forced into the reactor core through each of the cold legs in the event the RCS pressure falls below the pressure of the safety injection tanks. This initial surge of water into the core provides the initial cooling mechanism during large RCS pipe ruptures.

The limits on safety injection tank volume, boron concentration and pressure ensure that the assumptions used for safety injection tank injection in the accident analysis are met.

The safety injection tank power operated isolation valves are considered to be "operating bypasses" in the context of IEEE Std. 279-1971, which requires that bypasses of a protective function be removed automatically whenever permissive conditions are not met. In addition, as these safety injection tank isolation valves fail to meet single failure criteria, removal of power to the valves is required.

The limits for operation with a safety injection tank inoperable for any reason except an isolation valve closed minimizes the time exposure of the plant to a LOCA event occuring concurrent with failure of an additional safety injection tank which may result in unacceptable peak cladding temperatures. If a closed isolation valve cannot be immediately opened, the full capability of one safety injection tank is not available and prompt action is required to place the reactor in a mode where this capability is not required.

\section{$3 / 4.5 .2$ and $3 / 4.5 .3$ ECCS SUBSYSTEMS}

The OPERABILITY of two separate and independent ECCS subsystems ensures that sufficient emergency core cooling capability will be available in the event of a LOCA assuming the loss of one subsystem through any single failure consideration. Either subsystem operating in conjunction with the safety injection tanks is capable of supplying sufficient core cooling to limit the peak cladding temperatures within acceptable limits for all postulated break sizes ranging from the double ended break of the largest RCS cold leg pipe downward. In addition, each ECCS subsystem provides long term core cooling capability in the recirculation mode during the accident recovery period. 
EMERGENCY CORE COOLING SYSTEMS

BASES

ECCS SUBSYSTEMS (Continued)

With the RCS temperature below $300^{\circ} \mathrm{F}$, one OPERABLE ECCS subsystem is acceptable without single failure consideration on the basis of the stable reactivity condition of the reactor and the limited core cooling requirements.

The trisodium phosphate dodecahydrate (TSP) stored in dissolving baskets located in the containment basement is provided to minimize the prossibility of corrosion cracking of certain metal components during operation of the ECCS following a LOCA. The TSP provided this protection by dissolving in the sump water and causing its final $\mathrm{pH}$ to be raised to greater than or equal to 7.0 .

The limitation for a maximum of one high pressure safety injection pump to be OPERABLE, and the Surveillance Requirement to verify all high pressure safety injection pumps except the required OPERABLE pump to be inoperable below $(275)^{\circ} \mathrm{F}$, provides assurance that a mass addition pressure transient can be relieved by the operation of a single PORV.

The Surveillance Requirements provided to ensure OPERABILITY of each component ensures that at a minimum, the assumptions used in the accident analyses are met and that subsystem OPERABILITY is maintained. Surveillance requirements for throttle valve position stops and flow balance testing provide as surance. that proper ECCS flows will be maintained in the event of a LOCA. Maintenance of proper flow resistance and pressure drop in the piping system to each injection point is necessary to: (1) prevent total pump flow from exceeding runout conditions when the system is in its minimum resistance configuration, (2) provide the proper flow split between injection points in accordance with the assumptions used in the ECCS-LOCA analyses, and (3) provide an acceptable level of total ECCS flow to all injection points equal to or above that assumed in the ECCS-LOCA analyses. The requirement to dissolve a representative sample of TSP in a sample of RWT water provides assurance that the stored TSP will dissolve in borated water at the postulated post LOCA temperatures.

\section{3/4.5.4 REFUELING WATER TANK (RWT)}

The OPERABILITY of the RWT as part of the ECCS ensures that a sufficient supply of borated water is available for injection by the ECCS in the event of a LOCA. The limits on RWT minimum volume and boron concentration ensure that 1) sufficient water is available within containment to permit recirculation cooling flow to the core, and 2) the reactor will remain subcritical in the cold condition following mixing of the RWT and the RCS water volumes with all control rods inserted except for the most reactive control assembly. These as sumptions are consistent with the LOCA analyses. 


\section{BASES}

\section{REFUELING WATER TANK (Continued)}

The contained water volume limit includes an allowance for water not usable because of tank discharge line location or other physical characteristics.

The limits on contained water volume and boron concentration of the RWT also ensure a pH value of between $(8.9)$ and $(11.0)$ for the solution recirculated within containment after a LOCA. This $\mathrm{pH}$ band minimizes the evolution of iodine and minimizes the effect of chloride and caustic stress corrosion on mechanical systems and components. 
○

-

• 


\section{BASES}

FOR

SECTION $3 / 4.6 F$

CONTAINMENT SYSTEMS SPECIFICATIONS

FOR

COMBUSTION ENGINEERING

ATMOSPHERIC TYPE CONTAINMENT 
-

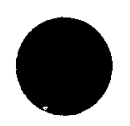

• 
$3 / 4.6$ CONTAINMENT SYSTEMS

BASES

3/4.6.1 PRIMARY CONTAINMENT

3/4.6.1.1 CONTAINMENT INTEGRITY

Primary CONTAINMENT INTEGRITY ensures that the release of radioactive materials from the containment atmosphere will be restricted to those leakage paths and associated leak rates assumed in the accident analyses. This restriction, in conjunction with the leakage rate limitation, will limit the site boundary radiation doses to within the limits of 10 CFR 100 during accident conditions.

\section{3/4.6.1.2 CONTAINMENT LEAKAGE}

The limitations on containment leakage rates ensure that the total containment leakage volume will not exceed the value assumed in the accident analyses at the peak accident pressure, $P_{1}$. As an added conservatism, the measured overall integrated leakage rate is further limited to less than or equal to

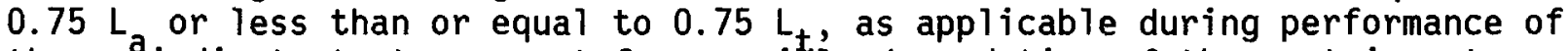
the periodic tests to account for possible degradation of the containment leakage barriers between leakage tests.

The surveillance testing for measuring leakage rates are consistent with the requirements of Appendix $J$ of 10 CFR 50 .

\section{3/4.6.1.3 CONTAINMENT AIR LOCKS}

The limitations on closure and leak rate for the containment air locks are required to meet the restrictions on CONTAINMENT INTEGRITY and containment leak rate. Surveillance testing of the air lock seals provides assurance that the overall air lock leakage will not become excessive due to seal damage during the intervals between air lock leakage tests.

\section{3/4.6.1.4 CONTAINMENT ISOLATION VALVE AND CHANNEL WELD PRESSURIZATION SYSTEMS (OPTIONAL)}

The OPERABILITY of the jsolation valve and containment channel weld pressurization systems is required to meet the restrictions on overall containment leak rate assumed in the accident analyses. The Surveillance Requirements for determining OPERABILITY are consistent with Appendix $\mathrm{J}$ of 10 CFR 50. 
CONTAINMENT SYSTEMS

3/4.6.1.5 INTERNAL PRESSURE

The limitations on containment internal pressure ensure that 1) the containment structure is prevented from exceeding its design negative pressure differential with respect to the outside atmosphere of (3.0) psig and 2) the containment peak pressure does not exceed the design pressure of (54) psig during (LOCA or steam line break conditions).

The maximum peak pressure expected to be obtained from a (LOCA or steam line break) event is (45) psig. The limit of (3) psig for initial positive containment pressure will limit the total pressure to (48) psig which is less than the design pressure and is consistent with the accident analyses.

\section{3/4.6.1.6 AIR TEMPERATURE}

The limitation on containment average air temperature ensures that the overall containment average air temperature does not exceed the initial temperature condition assumed in the accident analysis for a (LOCA or steam line break accident).

\section{3/4.6.1.7 CONTAINMENT STRUCTURAL INTEGRITY}

(Prestressed concrete containment with ungrouted tendons.)

This limitation ensures that the structural integrity of the containment

will be maintained comparable to the original design standards for the life of the facility. Structural integrity is required to ensure that the containment will withstand the maximum pressure of (48) psig in the event of a (LOCA or steam line break accident). The measurement of containment tendon lift off force, the tensile tests of the tendon wires or strands, the visual examination of tendons, anchorages and exposed interior and exterior surfaces of the containment and the Type A leakage tests are sufficient to demonstrate this capability. (The tendon wire or strand samples will also be subjected to stress cycling tests and to accelerated corrosion tests to simulate the tendon's operating conditions and environment.)

The surveillance requirements for demonstrating the containment's structural integrity are in compliance with the recommendations of Regulatory Guide 1.35 "Inservice Surveillance of Ungrouted Tendons in Prestressed Concrete Containment Structures", January 1976.

(Reinforced concrete containment.)

This limitation ensures that the structural integrity of the containment will be maintained comparable to the original design standards for the life of the facility. Structural integrity is required to ensure that the containment 
CONTAINMENT SYSTEMS

BASES

CONTAINMENT STRIICTIIRAL INTEGRITY (Continued)

will withstand the maximum pressure of (48) psig in the event of a (LOCA or steam line break accident). A visual inspection in conjunction with the Type A leakage tests is sufficient to demonstrate this capability.

3/4.6.1.8 CONTAIMMENT VENTILATION SYSTEM

The containment purge supply and exhaust isolation valves are required to be closed during plant operation since these valves have not been demonstrated capable of closing during a (LOCA or steam line break accident). Maintaining these valves closed during plant operations ensures that excessive quantities of radioactive materials will not be released via the containment purge system.

3/4.6.2 DEPRESSURIZATION AND COOLING SYSTEMS

3/4.6.2.1 CONTAINMENT SPRAY SYSTEM

The OPERARILITY of the containment spray system ensures that containment depressurization and cooling capability will be available in the event of a LOCA. The pressure reduction and resultant lower containment leakage rate are consistent with the assumptions used in the accident analyses.

(Credit taken for iodine removal)

The containment spray system and the containment cooling system are redundant to each other in providing post accident cooling of the containment atmosphere. However, the containment spray system also provides a mechanism for removing iodine from the containment atmosphere and therefore the time requirements for restoring an inoperable spray system to OPERABLE status have been maintained consistent with that assigned other inoperable ESF equipment.

(No credit taken for iodine removal)

The containment spray system and the containment cooling system are redundant to each other in providing post accident cooling of the containment atmosphere. Since no credit has been taken for iodine removal by the containment spray system, the allowable out of service time requirements for the containment spray system and containment cooling system have been interrelated and adjusted to reflect this additional redundancy in cooling capability.

\section{3/4.6.2.2 SPRAY ADDITIVE SYSTEM (OPTIONAL)}

The OPERABILITY of the spray additive system ensures that sufficient $\mathrm{NaOH}$ is added to the containment spray in the event of a LOCA. The limits on NaOH 
CONTAINMENT SYSTEMS

BASES

SPRAY ADDITIVE SYSTEM (Continued)

volume and concentration ensure a pH value of between (8.9) and (11.0) for the solution recirculated within containment after a LOCA. This $\mathrm{pH}$ hand minimizes the evolution of iodine and minimizes the effect of chloride stress corrosion the effect of chloride and caustic stress corrosion on mechanical systems and components. The contained water volume limit includes an allowance for water not usable because of tank discharge line location or other physical characteristics. These assumptions are consistent with the iodine removal efficiency assumed in the accident analyses.

\section{3/4.6.2.3 CONTAINMENT COOLING SYSTEM (OPTIONAL)}

The OPERABILITY of the containment cooling system ensures that 1) the containment air temperature will be maintained within limits during normal operation, and 2) adequate heat removal capacity is available when operated in conjunction with the containment spray systems during post-LOCA conditions.

(Credit taken for iodine removal by spray systems)

The containment cooling system and the containment spray system are redundant to each other in providing post accident cooling of the containment atmosphere. As a result of this redundancy in cooling capability, the allowable out of service time requirements for the containment cooling system have been appropriately adjusted. However, the allowable out of service time requirements for the containment spray system have been maintained consistent with that assigned other inoperable ESF equipment since the containment spray system also provides a mechanism for removing iodine from the containment atmosphere.

(No credit taken for iodine removal by spray systems)

The containment cooling system and the containment spray system are redundant to each other is providing post accident cooling of the containment atmosphere. Since no credit has been taken for iodine removal by the containment spray system, the allowable out of service time requirements for the containment cooling system and containment spray system have been interrelated and adjusted to reflect this additional redundancy in cooling capacity.

\section{3/4.6.3 IODINE CLEANUP SYSTEM (OPTIONAL)}

The OPERABILITY of the containment iodine filter trains ensures that sufficient iodine removal capability will be available in the event of a LOCA. The reduction in containment iodine inventory reduces the resulting site 
BASES

IODINE CLEANUP SYSTEM (Continued)

boundary radiation doses associated with containment leakage. The operation of this system and resultant iodine removal capacity are consistent with the assumptions used in the LOCA analyses.

\section{3/4.6.4 CONTAINMENT ISOLATION VALVES}

The OPERABILITY of the containment isolation valves ensures that the containment atmosphere will be isolated from the outside environment in the event of a release of radioactive material to the containment atmosphere or pressurization of the containment. Containment isolation within the time limits specified ensures that the release of radioactive material to the environment will be consistent with the assumptions used in the analyses for a LOCA.

\section{3/4.6.5 COMBUISTIBLE GAS CONTROL}

The OPERABILITY of the equipment and systems reauired for the detection and control of hydrogen gas ensures that this equipment will be available to maintain the hydrogen concentration with in containment below its flammable limit during post-LOCA conditions. Either recombiner unit (or the purge system) is capable of controlling the expected hydrogen generation associated with 1) zirconium-water reactions, 2) radiolytic decomposition of water and 3 ) corrosion of metals within containment. These hydrogen control systems are consistent with the recommendations of Regulatory Guide 1.7, "Control of Combustible Gas Concentrations in Containment Following a LOCA", March 1971.

The hydrogen mixing systems are provided to ensure adequate mixing of the containment atmosphere following a LOCA. This mixing action will prevent localized accumulations of hydrogen from exceeding the flammable limit.

\section{3/4.6.6 PENETRATION ROOM EXHAUST AIR CLEANUP SYSTEM (OPTIONAL)}

The OPERABILITY of the penetration room exhaust system ensures that radioactive materials leaking from the containment atmosphere through containment penetrations following a LOCA are filtered and adsorbed prior to reaching the environment. The operation of this system and the resultant effect on offsite dosage calculations was assumed in the LOCA analyses.

\section{3/4.6.7 VACUUM RELIEF VALVES (OPTIONAL)}

The OPERABILITY of the primary containment to atmosphere vacuum relief valves ensures that the containment internal pressure does not become more negative than psi. This condition is necessary to prevent exceeding the containment design limit for internal pressure differential of (1.0) psi. 

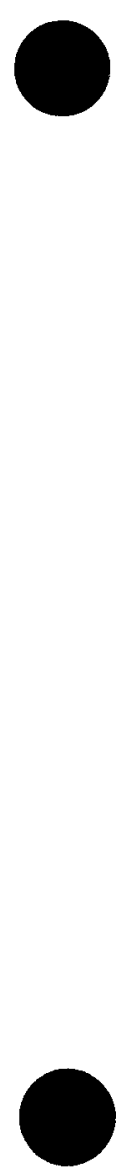

• 


\author{
BASES \\ FOR \\ SECTION $3 / 4.6 \mathrm{H}$ \\ CONTAINMENT SYSTEMS SPECIFICATIONS \\ FOR \\ COMBUSTION ENGINEERING \\ DUAL TYPE CONTAINMENTS
}


○

-

• 


\section{$3 / 4.6$ CONTAINMENT SYSTEMS}

BASES

3/4.6.1 PRIMARY CONTAINMENT

3/4.6.1.1 CONTAINMENT INTEGRITY

Primary CONTAINMENT INTEGRITY ensures that the release of radioactive materials from the containment atmosphere will be restricted to those leakage paths and associated leak rates assumed in the accident analyses. This restriction, in conjunction with the leakage rate limitation, will limit the site boundary radiation doses to within the limits of 10 CFR 100 during accident conditions.

\section{3/4.6.1.2 CONTAINMENT LEAKAGE}

The limitations on containment leakage rates ensure that the total containment leakage volume will not exceed the value assumed in the accident analyses at the peak accident pressure, $P$. As an added conservatism, the measured overall integrated leakage rate is further limited to less than or equal to $0.75 \mathrm{~L}$ or less than or equal to $0.75 \mathrm{~L}_{t}$, as applicable during performance of the periodic tests to account for possible degradation of the containment leakage barriers between leakage tests.

The surveillance testing for measuring leakage rates are consistent with the requirements of Appendix J of 10 CFR 50 .

\section{3/4.6.1.3 CONTAINMENT AIR LOCKS}

The limitations on closure and leak rate for the containment air locks are required to meet the restrictions on CONTAINMENT INTEGRITY and containment leak rate. Surveillance testing of the air lock seals provide assurance that the overall air lock leakage will not become excessive due to seal damage during the intervals between air lock leakage tests.

\section{3/4.6.1.4 CONTAINMENT ISOLATION VALVE AND CHANNEL WELD PRESSURIZATION} SYSTEMS (OPTIONAL)

The OPERABILITY of the isolation valve and containment channel weld pressurization systems is required to meet the restrictions on overall containment leak rate assumed in the accident analyses. The Surveillance Requirements for determining OPERABILITY are consistent with Appendix $J$ of 10 CFR 50. 
CONTAINMENT SYSTEMS

BASES

\section{$3 / 4.6 .1 .5$ INTERNAL PRESSURE}

The limitations on containment internal pressure ensure that 1) the containment structure is prevented from exceeding its design negative pressure differential with respect to the annulus atmosphere of (1.0) psi and 2) the containment peak pressure does not exceed the design pressure of (40) psig during (LOCA or steam line break) conditions.

The maximum peak pressure expected to be obtained from a (LOCA or steam line break) event is (35) psig. The limit of (2) psig for initial positive containment pressure will limit the total pressure to (37) psig which is less than the design pressure and is consistent with the accident analyses.

\section{3/4.6.1.6 AIR TEMPERATURE}

The limitation on containment average air temperature ensures that the containment peak air temperature does not exceed the design temperature of ( $)^{\circ} \mathrm{F}$ during (LOCA or steam Tine break) conditions and is consistent with the accident analyses.

\section{3/4.6.1.7 CONTAINMENT VESSEL STRUCTURAL INTEGRITY}

This limitation ensures that the structural integrity of the containment steel vessel will be maintained comparable to the original design standards for the life of the facility. Structural integrity is required to ensure that the vessel will withstand the maximum pressure of $(40)$ psig in the event of a (LOCA or steam line break accident). A visual inspection in conjunction with Type A leakage test is sufficient to demonstrate this capability.

\section{3/4.6.1.8 CONTAINMENT VENTILATION SYSTEM}

The containment purge supply and exhaust isolation valves are required to be closed during plant operation since these valves have not been demonstrated capable of closing during a (LOCA or steam line break). Maintaining these valves closed during plant operations ensures that excessive quantities of radioactive materials will not be released via the containment purge system.

3/4.6.2 DEPRESSURIZATION AND COOLING SYSTEMS

\section{3/4.6.2.1 CONTAINMENT SPRAY SYSTEM}

The OPERABILITY of the containment spray system ensures that cortainment depressurization and cooling capbility will be available in the event of a LOCA. The pressure reduction and resultant lower containment leakage rate are consistent with the assumiptions used in the accident analyses. 
CONTAINMENT SYSTEMS

BASES

CONTAINMENT SPRAY SYSTEM (Continued)

(Credit taken for iodine removal)

The containment spray system and the containment cooling system are redundant to each other in providing post accident cooling of the containment atmosphere. However, the containment spray system also provides a mechanism for removing iodine from the containment atmosphere and therefore the time requirements for restoring an inoperable spray system to OPERABLE status have been maintained consistent with that assigned other inoperable ESF equipment.

(No credit taken for iodine removal)

The containment spray system and the containment cooling system are redundant to each other in providing post accident cooling of the containment atmosphere. Since no credit has been taken for iodine removal by the containment spray system, the allowable out of service time requirements for the containment spray system and containment cooling system have been interrelated and adjusted to reflect this additional redundancy in cooling capability.

\section{3/4.6.2.2 SPRAY ADDITIVE SYSTEM (OPTIONAL)}

The OPERABILITY of the spray additive system ensures that sufficient $\mathrm{NaOH}$ is added to the containment spray in the event of a LOCA. The limits on NaOH volume and concentration ensure a pH value of between (8.5) and (11.0) for the solution recirculated within containment after a LOCA. This $\mathrm{pH}$ band minimizes the evolution of iodine and minimizes the effect of chloride and caustic stress corrosion on mechanical systems and components. The contained water volume limit includes an allowance for water not usable because of tank discharge line location or other physical characteristics. These assumptions are consistent with the iodine removal efficiency assumed in the accident analyses.

\section{3/4.6.2.3 CONTAINMENT COOLING SYSTEM (OPTIONAL)}

The OPERABILITY of the containment cooling system ensures that 1) the containment air temperature will be maintained within limits during normal operation, and 2) adequate heat removal capacity is available when operated in conjunction with the containment spray systems during post-LOCA conditions. 
CONTAINMENT SYSTEMS

BASES

CONTAINMENT COOLING SYSTEM (Continued)

(Credit taken for iodine removal by spray systems)

The containment cooling system and the containment spray system are redundant to each other in providing post accident cooling of the containment atmosphere. As a result of this redundancy in cooling capability, the allowable out of service time requirements for the containment cooling system have been appropriately adjusted. However, the allowable out of service time requirements for the containment spray system have been maintained consistent with that assigned other inoperable ESF equipment since the containment spray system also provides a mechanism for removing iodine from the containment atmosphere.

(No credit taken for iodine removai by spray systems)

The containment cooling system and the containment spray system are redundant to each other in providing post accident cooling of the containment atmosphere. Since no credit has been taken for iodine removal by the containment spray system, the allowabie out of service time requirements for the containment cooling system and containment spray system have been interrelated and adjusted to reflect this additional redundancy in cooling capacity.

\section{3/4.6.3 IODINE CLEANUP SYSTEM (OPTIONAL)}

The OPERABILITY of the containment iodine filter trains ensures that sufficient iodine removal capability will be available in the event of a LOCA. The reduction in containment iodine inventory reduces the resulting site boundary radiation doses associated with containment leakage. The operation of this system and resultant iodine removal capacity are consistent with the assumptions used in the LOCA analyses.

\section{3/4.6.4 CONTAINMENT ISOLATION VALVES}

The OPERABILITY of the containment isolation valves ensures that the containment atmosphere will be isolated from the outside environment in the event of a release of radioactive material to the containment atmosphere or pressurization of the containment. Containment isolation within the time limits specified ensures that the release' of radioactive material to the environment will be consistent with the assumptions used in the analyses for a LOCA. 
CONTAINMENT SYSTEMS

BASES

\section{3/4.6.5 COMBUSTIBLE GAS CONTROL}

The OPERABILITY of the equipment and systems required for the detection and control of hydrogen gas ensures that this equipment will be available to maintain the hydrogen concentration within containment below its flammable limit during post-LOCA conditions. Either recombiner unit (or the purge system) is capable of controlling the expected hydrogen generation associated with 1) zirconium-water reactions, 2) radiolytic decomposition of water and 3 ) corrosion of metals within containment. These hydrogen control systems are consistent with the recommendations of Regulatory Guide 1.7, "Control of Combustible Gas Concentrations in Containment Following a LOCA", March 1971.

The hydrogen mixing systems are provided to ensure adequate mixing of the containment atmosphere following a LOCA. This mixing action will prevent localized accumulations of hydrogen from exceeding the flammable limit.

\section{3/4.6.6 PENETRATION ROOM EXHAUST AIR CLEANUP SYSTEM (OPTIONAL)}

The OPERABILITY of the penetration room exhaust system ensures that radioactive materials leaking from the containment atmosphere through containment penetrations following a LOCA are filtered and adsorbed prior to reaching the environment. The operation of this system and the resultant effect on offsite dosage calculations was assumed in the LOCA analyses.

\section{3/4.6.7 VACUUM RELIEF VALVES (OPTIONAL)}

The OPERABILITY of the primary containment to atmosphere vacuum relief valves ensures that the containment internal pressure differential does not become more negative than () psi. This condition is necessary to prevent exceeding the containment design limit for internal pressure differential of (1.0) psi. 
CONTAIMMENT SYSTEMS

BASES

3/4.6.8 SECONDARY CONTAINMENT

3/4.6.8.1 SHIELD BUILDING AIR CLEANUP SYSTEM

The OPERABILITY of the shield building air cleanup systems ensures that containment vessel leakage occurring during LOCA conditions into the annulus will be filtered through the HEPA filters and charcoal adsorber trains prior to discharge to the atmosphere. This requirement is necessary to meet the assumptions used in the accident analyses and limit the site boundary radiation doses to within the limits of 10 CFR 100 during LOCA conditions.

\section{3/4.6.8.2 SHIELD BUILDING INTEGRITY}

SHIELD BUILDING INTEGRITY ensures that the release of radioactive materials from the primary containment atmosphere will be restricted to those leakage paths and associated leak rates assumed in the accident analyses. This restriction, in conjunction with operation of the shield building ventilation system, will limit the site boundary radiation doses to within the limits of $10 \mathrm{CFR}$ 100 during accident conditions.

\section{3/4.6.8.3 SHIELD BUILDING STRUCTURAL INTEGRITY}

This limitation ensures that the structural integrity of the containment shield building will be maintained comparable to the original design standards for the life of the facility. Structural integrity is required to provide 1) protection for the steel vessel from external missiles, 2) radiation shielding in the event of a LOCA, and 3) an annulus surrounding the steel vessel that can be maintained at a negative pressure during accident conditions. A visual inspection is sufficient demonstrate this capability. 


\section{$\underline{3 / 4.7}$ PLANT SYSTEMS}

BASES

\section{3/4.7.1 TURBINE CYCLE}

\section{3/4.7.1.1 SAFETY VALVES}

The OPERABILITY of the main steam line code safety valves ensures that the secondary system pressure will be limited to within $110 \%$ (1100 psig) of its design pressure of (1000) psig during the most severe anticipated system operational transient. The maximum relieving capacity is associated with a turbine trip from 100\% RATED THERMAL POWER coincident with an assumed loss of condenser heat sink (i.e., no steam bypass to the condenser).

The specified valve lift settings and relieving capacities are in accordance with the requirements of Section III of the ASME Boiler and Pressure Code, 1971 Edition. The total relieving capacity for all valves on all of the steam lines is () )lbs/hr which is () percent of the total secondary steam flow of ( ) lbs/hr at 100\% RATED THERMAL POWER. A minimum of (2) OPERABLE safety valves per steam generator ensures that sufficient relieving capacity is available for removing decay heat.

STARTUP and/or POWER OPERATION is allowable with safety valves inoperable within the limitations of the ACTION requirements on the basis of the reduction in secondary system steam flow and THERMAL POWER required by the reduced reactor trip settings of the Power Level-High channels. The reactor trip setpoint reductions are derived on the following bases:

For two loop operation

$$
S P=\frac{(X)-(Y)(V)}{X} \times
$$

For single loop operation (two reactor coolant pumps operating in the same loop)

$$
S P=\frac{(X)-(Y)(U)}{X} \times(* *)
$$

where:

$$
\begin{aligned}
S P & =\begin{array}{l}
\text { reduced reactor trip setpoint in percent of RATED THERMAL } \\
\text { POWER }
\end{array} \\
V & =\text { maximum number of inoperable safety valves per steam line }
\end{aligned}
$$


PLANT SYSTEMS

BASES

SAFETY VALVES (Continued)

$U=$ maximum number of inoperable safety valves per operatinq steam line

(125) = Power Level-High Trip Setpoint for two loop operation

$(* *)=$ Power Level-High Trip Setpoint for single loop operation with two reactor coolant pumps operating in the same loop

$X=$ Total relieving capacity of all safety valves per steam line in lbs/hour ( $1 \mathrm{bs} / \mathrm{hr}$ )

$\mathrm{Y}=$ Maximum relieving capacity of any one safety valve in lbs/hour ( 1 ibs/hr)

\section{3/4.7.1.2 EMERGENCY FEEDWATER SYSTEM}

The OPERABILITY of the auxiliary feedwater system ensures that the Reactor Coolant System can be cooled down to less than $(350)^{\circ} \mathrm{F}$ from normal operating conditions in the event of a tota? loss of off-site power.

Each electric driven auxiliary feedwater pump is capable of delivering a total feedwater flow of (350) gpm at a pressure of (1700) psig to the entrance of the steam generators. The steam driven auxiliary feedwater pump is capable of delivering a total feedwater flow of (700) gpm at a pressure of (1100) psig to the entrance of the steam generators. This capacity is sufficient to ensure that adequate feedwater flow is available to remove decay heat and reduce the Reactor Coolant System temperature to less than $(350)^{\circ} \mathrm{F}$ when the shutdown cooling system may be placed into operation.

\section{3/4.7.7.3 CONDENSATE STORAGE TANK}

The OPERABILITY of the condensate storage tank with the minimum water volume ensures that sufficient water is available to maintain the RCS at HOT STANDBY conditions for () hours with steam discharge to atmosphere with concurrent with total loss of off-site power. The contained water volume limit includes an allowance for water not usable because of tank discharge line location or other physical characteristics. 
PLANT SYSTEMS

BASES

3/4.7.1.4 ACTIVITY

The limitations on secondary system specific activity ensure that the resultant off-site radiation dose will be 1 imited to a small fraction of 10 CFR Part 100 limits in the event of a steam line rupture. This dose also includes the effects of a coincident $1.0 \mathrm{GPM}$ primary to secondary tube leak in the steam generator of the affected steam line and a concurrent loss of offsite electrical power. These values are consistent with the assumptions used in the accident anaiyses.

\section{3/4.7.1.5 MAIN STEAM LINE ISOLATION VALVE}

The OPERABILITY of the main steam line isolation valves ensures that no more than one steam generator will blowdown in the event of a steam line rupture. This restriction is required to 1) minimize the positive reactivity effects of the Reactor Coolant System cooldown associated with the blowdown, and 2) limit the pressure rise within containment in the event the steam line rupture occurs within containment. The OPERABILITY of the main steam isolation valves within the closure times of the surveillance requirements are consistent with the assumptions used in the accident analyses.

\section{3/4.7.2 STEAM GENERATOR PRESSURE/TEMPERATURE LIMITATION}

The limitation on steam generator pressure and temperature ensures that the pressure induced stresses in the steam generators do not exceed the maximum allowable fracture toughness stress limits. The limitations to $(90)^{\circ} \mathrm{F}$ and (275) psig are based on a steam generator $\mathrm{RT}_{\text {NDT }}$ of $(30)^{\circ} \mathrm{F}$ and are sufficient to prevent brittle fracture.

\section{3/4.7.3 COMPONENT COOLING WATER SYSTEM}

The OPERABILITY of the component cooling water system ensures that sufficient cooling capacity is available for continued operation of safety related equipment during normal and accident conditions. The redundant cooling capacity of this system, assuming a single failure, is consistent with the assumptions used in the accident analyses.

\section{3/4.7.4 SERVICE WATER SYSTEM}

The OPERABILITY of the service water system ensures that sufficient cooling capacity is available for continued operation of equipment during normal and accident conditions. The redundant cooling capacity of this system, assuming a single failure, is consistent with the assumptions used in the accident analyses. 
PLANT SYSTEMS

BASES

3/4.7.5 ULTIMATE HEAT SINK (OPTIONAL)

The limitations on the ultimate heat sink level and temperature ensure that sufficient cooling capacity is available to either 1) provide normal cooldown of the facility, or 2) to mitigate the effects of accident conditions within acceptable limits.

The limitations on minimum water level and maximum temperature are based on providing a 30 day cooling water supply to safety related equipment without exceeding their design basis temperature and is consistent with the recommendations of Regulatory Guide 1.27, "Ult imate Heat Sink for Nuclear Plants", March 1974.

\section{$3 / 4.7 .6$ FLOOD PROTECTION (OPTIONAL)}

The limitation on flood protection ensures that facility protective actions will be taken (and operation will be terminated) in the event of flood conditions. The limit of elevation (_) Mean Sea Level is based on the maximum elevation at which facility flood control measures provide protection to safety related equipment.

\section{3/4.7.7 CONTROL ROOM EMERGENCY AIR CLEANUP SYSTEM}

The OPERABILITY of the control room emergency air cleanup system ensures that 1) the ambient air temperature does not exceed the allowable temperature for continuous duty rating for the equipinent and instrumentation cooled by this system and 2) the control room will remain habitable for operations personnel during and following all credible accident conditions. The OPERABILITY of this system in conjunction with control room design provisions is based on limiting the radiation expsoure to personnel occupying the control room to 5 rem or less whole body, or its equivalent. This limitation is consistent with the requirements of General Design Criteria 19 of Appendix $A$, 10 CFR 50.

\section{$3 / 4.7 .8$ ECCS PUMP ROOM EXHAUST AIR CLEANUP SYSTEM}

The OPERABILITY of the ECCS pump room exhaust air cleanup system ensures that radioactive materials leaking from the ECCS equipment within the pump room following a LOCA are filtered prior to reaching the environment. The operation of this system and the resultant effect on offsite dosage calculations was assumed in the accident analyses. 


\section{3/4.7.9 HYDRAULIC SNUBBERS}

The hydraulic snubbers are required OPERABLE to ensure that the structural integrity of the reactor coolant system and all other safety related systems is maintained during and following a seismic or other event initiating dynamic loads. The only snubbers excluded from this inspection program are those installed on nonsafety related systems and then only if their failure or failure of the system on which they are installed, would have no adverse effect on any safety related system.

The inspection frequency applicable to snubbers containing seals fabricated from materials which have been demonstrated compatible with their operating environment is based upon maintaining a constant level of snubber protection. Therefore, the required inspection interval varies inversely with the observed snubber failures. The number of inoperable snubbers found during an inspection of these snubbers determines the time interval for the next required inspection of these snubbers. Inspections performed before that interval has elapsed may be used as a new reference point to determine the next inspection. However, the results of such early inspections performed before the original required time interval has elapsed (nominal time less 25\%) may not be used to lengthen the required inspection interval. Any inspection whose results require a shorter inspection interval will override the previous schedule.

To provide further assurance of snubber reliability, a representative sample of the installed snubbers will be functionally tested during plant shutdowns at 18 month intervals. These tests will include stroking of the snubbers to verify proper piston movement, lock-up and bleed. Observed failures of these sample snubbers will require functional testing of additional units. To minimize personnel exposures, snubbers installed in areas which have high radiation fields during shutdown or in especially difficult to remove locations may be exempted from these functional testing requirements provided the OPERABILITY of these snubbers was demonstrated during functional testing at either the completion of their fabrication or at a subsequent date.

\section{3/4.7.10 SEALED SOURCE CONTAMINATION}

The limitations on removable contamination for sources requiring leak testing, including alpha emitters, is based on 10 CFR 70.39(c) 1 imits for plutonium. This limitation will ensure that leakage from byproduct, source, and special nuclear material sources will not exceed allowable intake values.

Sealed sources are classified into three groups according to their use, with survefliance requirements commensurate with the probability of damage to 
PLANT SYSTEMS

BASES

SEALED SOURCE CONTAMINATION (Continued)

a source in that group. Those sources which are frequently handled are required to be tested more often than those which are not. Sealed sources which are continuously enclosed within a shielded mechanism (i.e. sealed sources within radiation monitoring or boron measuring devices) are considered to be stored and need not be tested unless they are removed from the shield mechanism.

\section{$3 / 4.7 .11$ FIRE SUPPRESSION SYSTEMS}

The OPERABILITY of the fire suppression systems ensures that adequate fire suppression capability is available to confine and extinguish fires occurring in any portion of the facility where safety related equipment is located. The fire suppression system consists of the water system, spray and/or sprinklers, $\mathrm{CO}_{2}$, Halon, fire hose stations, and yard fire hydrants. The collective capabifity of the fire suppression systems is adequate to minimize potential damage to safety related equipment and is a major element in the facility fire protection program.

In the event that portions of the fire suppression systems are inoperable, alternate backup fire fighting equipment is required to be made available in the affected areas until the inoperable equipment is restored to service.

In the event the fire suppression water system becomes inoperable, immediate corrective measures mst be taken since this system provides the major fire suppression capability of the plant. The requirement for a twentyfour hour report to the Commission provides for prompt evaluation of the acceptability of the corrective measures to provide adequate fire suppression capabilty for the continued protection of the nuclear plant.

\section{3/4.7.12 FIRE BARRIER PENETRATIONS}

The functional integrity of the fire barrier penetrations ensures that fires will be confined or adequately retarded from spreading to adjacent portions of the facility. This design feature minimizes the possibility of a single fire rapidly involving several areas of the facility prior to detection and extinguishment. The fire barrier penetrations are a passive element in the facility fire protection program and are subject to periodic inspections.

Fire barrier penetrations, including cable penetration barriers, fire doors and dampers are considered functional when the visually observed condition is the same as the as-designed condition. For those fire barrier penetrations that are not in the as-designed condition, an evaluation shall be performed to show that the modification has not degraded the fire rating of the fire barrier penetration. 


\section{FIRE BARRIER PENETRATIONS (Continued)}

During periods of time when a barrier is not functional, either, 1) a continuous fire watch is required to be maintained in the vicinity of the affected barrier, or 2) the fire detectors on at least one side of the affected barrier must be verified OPERABLE and a hourly fire watch patrol established, until the barrier is restored to functional status.

\section{3/4.7.13 AREA TEMPERATURE MONITORING}

The area temperature limitations ensure that safety related equipment will not be subjected to temperatures in excess of their environmental qualification temperatures. Exposure to excessive temperatures may degrade equipment and can cause a loss of its OPERABILITY. The temperature limits include an allowance for instrument error of ()$^{\circ} \mathrm{F}$. 

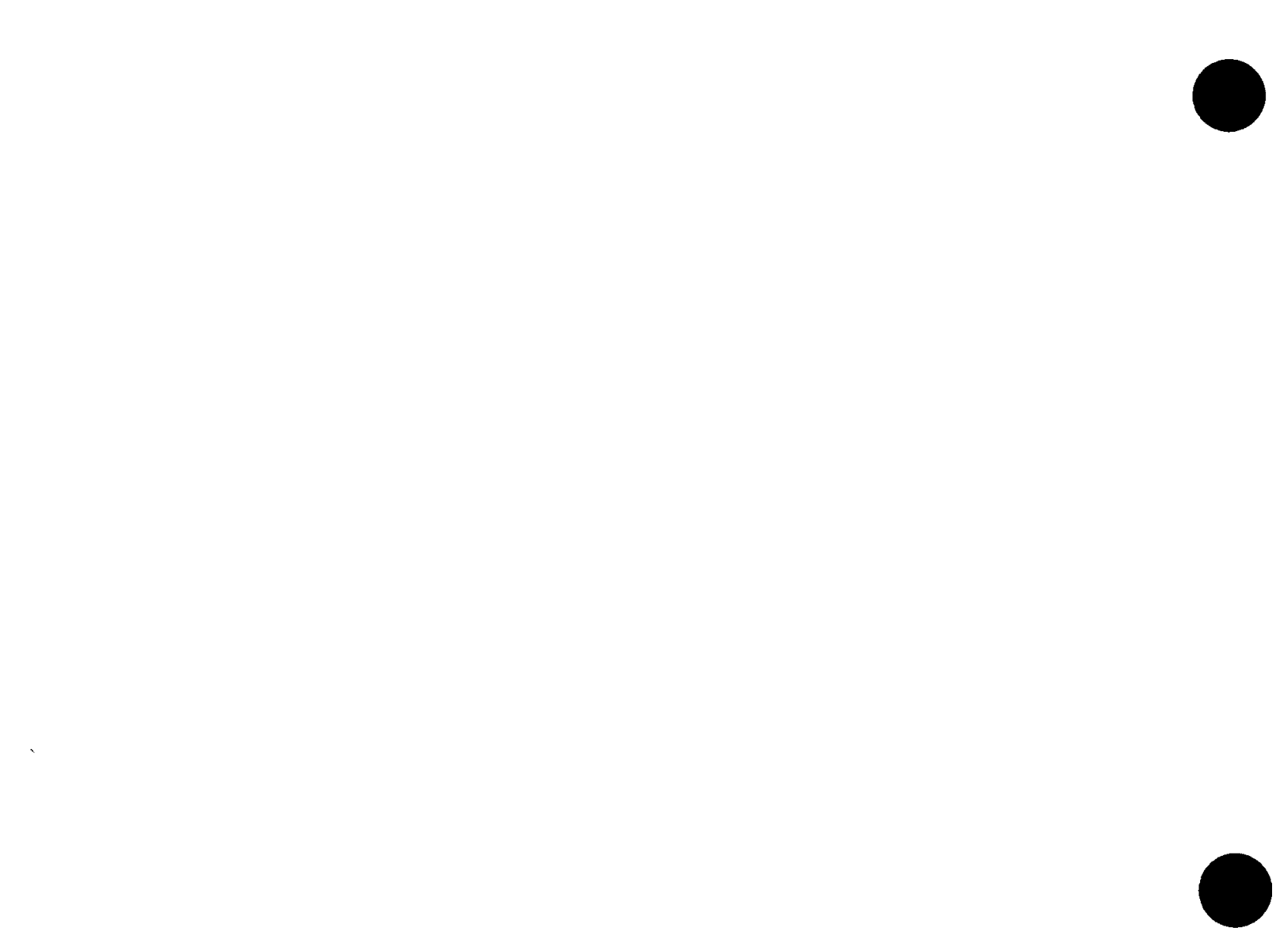

• 


\section{3/4.8 ELECTRICAL POWER SYSTEMS}

BASES

3/4.8.1 and 3/4.8.2 A.C. SOURCES and ONSITE POWER DISTRIBUTION SYSTEMS

The OPERABILITY of the A.C. and D.C. power sources and associated distribution systems during operation ensures that sufficient power will be available to supply the safety related equipment required for 1) the safe shutdown of the facility and 2) the mitigation and control of accident conditions within the facility. The minimum specified independent and redundant A.C. and D.C. power sources and distribution systems satisfy the requirements of General Design Criteria 17 of Appendix "A" to 10 CFR 50.

The ACTION requirements specified for the levels of degradation of the power sources provide restriction upon continued facility operation commensurate with the level of degradation. The OPERABILITY of the power sources are consistent with the initial condition assumptions of the safety analyses and are based upon maintaining at least one redundant set of onsite $A_{\text {. }}$. . and D.C. power sources and associated distribution systems OPERABLE during accident conditions coincident with an assumed loss of offsite power and single failure of the other onsite A.C. source.

The OPERABILITY of the minimum specified A.C. and D.C. power sources and associated distribution systems during shutdown and refueling ensures that 1) the facility can be maintained in the shutdown or refueling condition for extended time periods and 2) sufficient instrumentation and control capability is available for monitoring and maintaining the unit status.

The Surveillance Requirements for demonstrating the OPERABILITY of the diesel generators are in accordance with the recommendations of Regulatory Guides 1.9 "Selection of Diese] Generator Set Capacity for Standby Power Supplies," March 10, 1971, and 1.108 "Periodic Testing of Diesel Generator Units Used as Onsite Electric Power Systems at Nuclear Power Plants," Revision 1, August 1977.

The Surveillance Requirement for demonstrating the OPERABILITY of the Station batteries are in accordance with the recommendations of Regulatory Guide 1.129 "Maintenance Testing and Replacement of Large Lead Storage Batteries for Nuclear Power Plants," February 1978.

\section{3/4.8.3 ELECTRICAL EQUIPMENT PROTECTIVE DEVICES}

Containment electrical penetrations and penetration conductors are protected by either deenergizing circuits not required during reactor operation or by demonstrating the OPERABILITY of primary and backup overcurrent protection circuit breakers during periodic surveillance. 


\section{ELECTRICAL POWER SYSTEMS}

\section{BASES}

\section{ELECTRICAL EQUIPMENT PROTECTIVE DEVICES (Continued)}

The surveillance requirements applicable to lower voltage circuit breakers and fuses provides assurance of breaker and fuse reliability by testing at least one representative sample of each manufacturers brand of circuit breaker and/or fuse. Each manufacturer's molded case and metal case circuit breakers and/or fuses are grouped into representative samples which are then tested on a rotating basis to ensure that all breakers and/or fuses are tested. If a wide variety exists within any manufacturer's brand of circuit breakers and/or fuses it is necessary to divide that manufacturer's breakers and/or fuses into groups and treat each group as a separate type of breaker or fuses for surveillance purposes.

The OPERABILITY of the motor operated valves thermal overload protection and/or bypass devices ensures that these devices will not prevent safety related valves from performing their function. The Surveillance Requirements for demonstrating the OPERABILITY of these devices are in accordance with Regulatory Guide 1.106 "Thermal Overload Protection for Electric Motors on Motor Operated Valves", Revision 1, March 1977. 
3/4.9 REFUELING OPERATIONS

BASES

\section{3/4.9.1 BORON CONCENTRATION}

The limitations on reactivity conditions during REFUELING ensure that: 1) the reactor will remain subcritical during CORE ALTERATIONS, and 2) a uniform boron concentration is maintained for reactivity control in the water volume having direct access to the reactor vessel. These limitations are consistent with the initial conditions assumed for the boron dilution incident in the accident analyses.

\section{3/4.9.2 INSTRUMENTATION}

The OPERABILITY of the source range neutron flux monitors ensures that redundant monitoring capability is avajlable to detect changes in the reactivity condition of the core.

\section{3/4.9.3 DECAY TIME}

The minimum requirement for reactor subcriticality prior to movement of irradiated fuel assemblies in the reactor pressure vessel ensures that sufficient time has elapsed to allow the radioactive decay of the short lived fission products. This decay time is consistent with the assumptions used in the accident analyses.

\section{3/4.9.4 CONTAINMENT PENETRATIONS}

The requirements on containment penetration closure and OPERABILITY ensure that a release of radioactive material within containment will be restricted from leakage to the environment. The OPERABILITY and closure restrictions are sufficient to restrict radioactive material release from a fuel element rupture based upon the lack of containment pressurization potential while in the REFUELING MODE.

\section{$3 / 4.9 .5$ COMMUNICATIONS}

The requirement for communications capability ensures that refueling station personnel can be promptly informed of significant changes in the facility status or core reactivity condition during CORE ALTERATIONS. 
REFUELING OPERATIONS

BASES

\section{3/4.9.6 MANIPULATOR CRANE OPERABILITY}

The OPERABILITY requirements for the refueling machine ensure that: 1) manipulator cranes will be used for movement of CEAs and fuel assemblies, 2 ) each crane has sufficient load capacity to lift a CEA or fuel assembly, and 3) the core internals and pressure vessel are protected from excessive lifting force in the event they are inadvertently engaged during lifting operations.

\section{3/4.9.7 CRANE TRAVEL - SPENT FUEL STORAGE BUILDING}

The restriction on movement of loads in excess of the nominal weight of a fuel assembly, CEA and associated handling tool over other fuel assemblies in the storage pool ensures that in the event this load is dropped (1) the activity release will be limited to that contained in a single fuel assembiy, and (2) any possibie distortion of fuel in the storage racks will not result in a critical array. This as sumption is consistent with the activity release assumed in the accident analyses.

\section{3/4.9.8 COOLANT CIRCULATION}

The requirement that at least one shutdown cooling loop be in operation ensures that (1) sufficient cooling capacity is available to remove decay heat and maintain the water in the reactor pressure vessel below $140^{\circ} \mathrm{F}$ as required during the REFUELING MODE, and (2) sufficient coolant circulation is maintained through the reactor core to minimize the effects of a boron dilution incident and prevent boron stratification.

\section{3/4.9.9 CONTAINMENT PURGE VALVE ISOLATION SYSTEM}

The OPERABILITY of this system ensures that the containment purge valves will be automatically isolated upon detection of high radiation levels within the containment. The OPERABILITY of this system is required to restrict the release of radioactive material from the containment atmosphere to the environment. 
REFUELING OPERATIONS

BASES

3/4.9.10 and 3/4.9.11 WATER LEVEL-REACTOR VESSEL AND STORAGE POOL

The restrictions on minimum water level ensure that sufficient water depth is available to remove $99 \%$ of the assumed $10 \%$ iodine gap activity released from the rupture of an irradiated fuel assembly. The minimum water depth is consistent with the assumptions of the accident analysis.

\section{3/4.9.12 STORAGE POOL AIR CLEANUP SYSTEM}

The limitations on the storage pool air cleanup system ensure that al radioactive material released from an irradiated fuel assembly will be filtered through the HEPA filters and charcoal adsorber prior to discharge to the atmosphere. The OPERABILITY of this system and the resulting iodine removal capacity are consistent with the assumptions of the accident analyses. 

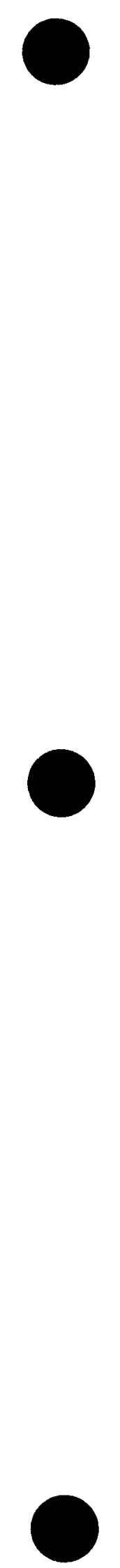
3/4.10 SPECIAL TEST EXCEPTIONS

BASES

3/4.10.1 SHUTDOWN MARGIN

This special test exception provides that a minimum amount of CEA worth is immediately available for reactivity control when tests are performed for CEAs worth measurement. This special test exception is required to permit the periodic verification of the actual versus predicted core reactivity condition occurring as a result of fuel burnup or fuel cycling operations.

\section{3/4.10.2 GROUP HEIGHT, INSERTION, AND POWER DISTRIBUTION LIMITS}

This special test exception permits individual CEAs to be positioned outside of their normal group heights and insertion limits during the performance of such PHYSICS TESTS as those required to 1) measure CEA worth and 2) determine the reactor stability index and damping factor under xenon oscillation conditions.

\section{3/4.10.3 REACTOR COOLANT LOOPS}

This special test exception permits reactor criticality under no flow conditions and is required to perform certain startup and PHYSICS TESTS while at low THERMAL POWER levels.

\section{3/4.10.4 CENTER CEA MISALIGNMENT}

This special test exception permits the center CEA to be misaligned during PHYSICS TESTS required to determine the isothermal temperature coefficient and power coefficient. 


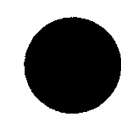

-

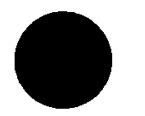


SECTION 5.0

DESIGN FEATURES 
-

-

• 
5.1 SITE

EXCLUSION AREA

5.1.1 The exclusion area shall be as shown in Figure (5.1-1).

LOW POPULATION ZONE

5.1.2 The low population zone shall be as shown in Figure (5.1-2).

5.2 CONTAI NMENT

CONFIGURATION

5.2.1 The reactor containment building is a steel lined, reinforced concrete building of cylindrical shape, with a dome roof and having the following design features:

a. Nominal inside diameter $=$ feet.

b. Nominal inside height $=$ feet.

c. Minimum thickness of concrete walls = feet.

d. Minimum thickness of concrete roof $=$ feet.

e. Minimum thickness of concrete floor pad $=$ feet.

f. Nominal thickness of steel liner $=$ inches.

g. Net free volume $=$ cubic feet.

DESIGN PRESSURE AND TEMPERATURE

5.2.2 The reactor containment building is designed and shall be maintained for a maximum internal pressure of psig and a temperature of ${ }^{\circ} \mathrm{F}$. 
This figure shall consist of a map of the site area and provide at a minimum, the information described in Section

(2.1.2) of the FSAR and meteorological tower location.

EXCLUSION AREA

FIGURE 5.7-1 
This figure shall consist of a map of the site area showing the Low Population Zone boundary. Features such as towns, roads and recreational areas shall be indicated in sufficient detail to allow identification of significant shifts in population distribution with in the LPZ.

\section{LOW POPULATION ZONE}

\section{FIGURE $5,1-2$}




\subsection{REACTOR CORE}

\section{FUEL ASSEMBLIES}

5.3.1 The reactor core shall contain fuel assemblies with each fuel assembly containing fuel rods clad with (Zircaloy-4). Each fuel rod shall have a nominal active fuel length of inches and contain a maximum total weight of grams uranium. The initial core loading shall have a maximum enrichment of weight percent $U-235$. Reload fuel shall be similar in physical design to the initial core loading and shall have a maximum enrichment of weight percent U-235.

\section{CONTROL ELEMENT ASSEMBLIES}

5.3.2 The reactor core shall contain control element assemblies. full Tength and part length

\subsection{REACTOR COOLANT SYSTEM}

\section{DESIGN PRESSURE AND TEMPERATURE}

5.4.1 The reactor coolant system is designed and shall be maintained:

a. In accordance with the code requirements specified in Section (5.2) of the FSAR with allowance for normal degradation pursuant of the applicable Surveillance Requirements,

b. For a pressure of __ psia, and

c. For a temperature of $\_{ }^{\circ} \mathrm{F}$, except for the pressurizer which is ${ }^{\circ} \mathrm{F}$. 
VOLUME

5.4.2 The total water and steam yolume of the reactor coolant system is \pm cubic feet at a nominal $\mathrm{T}_{\text {avg }}$ of $(525)^{\circ} \mathrm{F}$.

\subsection{METEOROLOGICAL TOWER LOCATION}

5.5.1 The meteorological tower shall be located as shown on Figure 5.1-1.

5.6 FUEL STORAGE

\section{CRITICALITY}

5.6.1 The spent fuel storage racks are designed and shall be maintained with:

a. A k equivalent to less than or equal to 0.95 when flooded with unbeffated water, which includes a conservative allowance of $(2.6 \%)$ delta $k / k$ for uncertainties as described in Section (4.3) of the FSAR.

b. A nominal (21) inch center-to-center distance between fuel assemblies placed in the storage racks.

5.6.2 The $k$ for new fuel for the first core loading stored dry in the spent fuel storage racks shall not exceed $(0.98)$ when aqueous foam moderation is assumed.

DRAINAGE

5.6.3 The spent fuel storage pool is designed and shall be maintained to prevent inadvertent draining of the pool below elevation

CAPACITY

5.6.4 The spent fuel storage pool is designed and shall be maintained with a storage capacity limited to no more than fuel assemblies.

\subsection{COMPONENT CYCLIC OR TRANSIENT LIMITS}

5.7.1 The components identified in Table 5.7-1 are designed and shall be maintained within the cyclic or transient limits of Table 5.7-1. 
TABLE 5.7-1

$n$
ñ
n

\section{COMPONENT}

Reactor Coolant System

G

(200) leak testing cycles.

(400) reactor trip cycles.

(40) turbine trip cycles with delayed reactor trip.

(200) seismic stress cycles.

\section{DESIGN CYCLE}

\section{OR TRANSIENT}

Heatup cycle $-\mathrm{T}$ from $<200^{\circ} \mathrm{F}$ to $>545^{\circ} \mathrm{F}$; cooldyg cycle $\mathrm{T}_{\text {avg }}$ from $\geq 545^{\circ} \mathrm{F}$ to $\leq 200^{\circ} \mathrm{F}$.

Heat cycle - Pressurizer temperature from $<200^{\circ} \mathrm{F}$ to $>653^{\circ} \mathrm{F}$; cooldown $\geq 653^{\circ} \mathrm{F}$ to $\leq 200^{\circ} \mathrm{F}$

RCS pressurized to 3110 psig with RCS temperature $>60^{\circ} \mathrm{F}$ above the most limiting components' NDTT value.

RCS pressured to 2250 psia with RCS temperature greater than minimum for hydrostatic testing, but less than minimum RCS temperature for critically.

Trip from $100 \%$ of RATED THERMAL POWER.

Turbine trip (total load rejection) from $100 \%$ of RATED THERMAL POWER. followed by resulting reactor trip.

Subjection to a seismic event equal to one half the design basis earthquake (DBE). 
TABLE 5.7-1 (Continued)

宂
in
in

COMPONENT

Reactor Coolant System

$\stackrel{1}{1}$

\section{COMPONENT CYCLIC OR TRANSIENT LIMITS}

\section{CYCLIC OR} TRANSIENT LIMIT

(40) complete loss of reactor coolant flow cycles.

(5) complete loss of secondary pressure cycles.

(100) pressurizer spray cycles per year with pressurizer/spray water $\Delta \mathrm{T}>200^{\circ} \mathrm{F}$ or as otherwise

calculated by the following method:
DESIGN CYCLE

OR TRANSIENT

Simultaneous loss of all Reactor Coolant Pumps at $100 \%$ of RATED THERMAL POWER.

Loss of secondary pressure from either steam generator while in MODES 1,2 or 3 .

Spray operation consisting of opening and closing either the main or auxiliary spray valves(s) spray water/pressurizer $\Delta T>200^{\circ} \mathrm{F}$. 
$n$
1
$n$
$n$
$n$

TABLE 5.7-1 (Continued)

COMPONENT CYCLIC OR TRANSIENT LIMITS

COMPONENT

CYCLIC OR

DESIGN CYCLE

TRANSIENT LIMIT

OR TRANSIENT

Reactor Coolant System

Method for Calculating Pressurizer Spray Nozzle Cumulative Usage Factor

$\Delta \mathrm{T}$

$\mathrm{N}_{\mathrm{A}}$

N

$\mathrm{N} / \mathrm{N}_{A}$

$201-300$

13,000

$301-400$

5,000

co
$\infty$

$401-500 \quad 3,000$

$501-600$

1,500

$\Sigma N / N_{A}$

Where:

$\Delta T=$ Temperature difference between pressurizer water and spray in ${ }^{\circ} \mathrm{F}$.

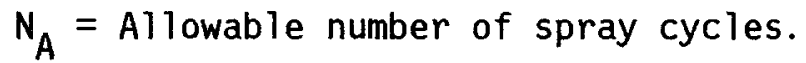

$\mathrm{N}=$ Number of cycles in $\Delta \mathrm{T}$ range indicated.

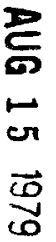


TABLE 5.7-1 (Continued)

吕

COMPONENT

Reactor Coolant System

Calculational Method:

1. At 12 month intervals the cumulative spray cycles shall be totaled.

If the total is equal to or less than 1000, no further action is required.

2. If the cumulative total exceeds 1000 , the spray nozzle usage factor shall be calculated as follows:

A. Fill in Column "N" above.

B. Calculate " $N / N_{A}$ " (Divide $N$ and $N_{A}$ ).

C. Add Column " $N / N_{A}$ " to find $\Sigma N / N_{A}$.

$\Sigma N / N_{A}$ is the cumulative spray nozzle usage factor. If the calculated usage factor is equal to or less than 0.75 , no further action is required.

3. If the calculated usage factor exceeds 0.75 , subsequent pressurizer spray operation shall be restricted so that the difference between the pressurizer water temperature and the spray water temperature shall be 1 imited to less than or equal to $200^{\circ} \mathrm{F}$ when spray is operated. An engineering evaluation of nozzle fatigue shall be performed and shall determine that that the nozzle remains acceptable for additional service prior to removing this restriction. 
-

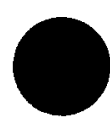

• 


\subsection{RESPONSIBILITY}

6. 1.1 The ( $\mathrm{Plant}$ Superintendent) shall be responsible for overallunit operation and shall delegate in writing the succession to this responsibility during his absence.

\subsection{ORGANIZATION}

\section{OFFSITE}

6.2.1 The offsite organization for unit management and technical support shall be as shown on Figure 6.2-1.

\section{UNIT STAFF}

6.2.2 The Unit organization shall be as shown on Figure 6.2-2 and:

a. Each on duty shift shall be composed of at least the minimum shift crew composition shown in Table 6.2-1.

b. At least one licensed Operator shall be in the control room when fuel is in the reactor.

c. At least two licensed Operators shall be present in the control room during reactor start-up, scheduled reactor shutdown and during recovery from reactor trips.

d. An individual qualified in radiation protection procedures shall be on site when fuel is in the reactor.

e. All CORE ALTERATIONS shall be directly supervised by either a licensed Senior Reactor Operator or Senior Reactor Operator Limited to Fue I Handling who has no other concurrent responsibilities during this operation.

f. A site Fire Brigade of at least 5 members shall be maintained onsite at all times\#. The Fire Brigade shall not include (3) members of the minimum shift crew necessary for safe shutdown of the unit and any personne1 required for other essential functions during a fire emergency.

\footnotetext{
\#Fire Brigade composition may be less than the minimum requirements for a period of time not be exceed 2 hours in order to accommodate unexpected absence of Fire Brigade members provided immediate action is taken to restore the Fire Brigade to within the minimum requirements.
} 
This figure shall show the organizational structure and lines of responsibility for the offsite groups that provide technical and management support for the unit. The organizational arrangement for performance and monitoring Quality Assurance activities should also be indicated.

Figure $6.2-1$

OFFSITE ORGANIZATION 
This figure shall show the organizational structure and lines of responsibility for the unit staff.

Positions to be staffed by licensed personnel should be indicated.

Figure $6.2-2$

UNIT ORGANIZATION 
TABLE 6.2-1

MINIMUM SHIFT CREW COMPOSITION\#

\begin{tabular}{|l|c|c|}
\hline \multirow{2}{*}{$\begin{array}{l}\text { LICENSE } \\
\text { CATEGORY }\end{array}$} & \multicolumn{2}{|c|}{ APPLICABLE MODES } \\
\cline { 2 - 3 } & $1,2,3 \& 4$ & $5 \& 6$ \\
\hline SOL & 1 & $1 *$ \\
\hline OL & 2 & 1 \\
\hline Non-Licensed & 2 & 1 \\
\hline
\end{tabular}

*Does not include the licensed Senior Reactor Operator or Senior Reactor Operator Limited to Fuel Handling, supervising CORE ALTERATIONS.

\# Shift crew composition may be less than the minimum requirements for a period of time not to exceed 2 hours in order to accommodate unexpected absence of on duty shift crew members provided immediate action is taken to restore the shift crew composition to within the minimum requirements of Table $6.2-1$. 


\subsection{UNIT STAFF QUALIFICATIONS}

Minimum qualifications for members of the unit staff may be specified by use of an overall qualification statement referencing ANSI N18.1-1971 orr alternately by specifying individual position qualifications. Generally, the first method is preferable; however, the second method is adaptable to those unit staffs requiring special qualification statements because of a unique organizational structure.

6.3.1 Each member of the unit staff shall meet or exceed the minimum qualifications of ANSI N18.1-1971 for comparable positions, except for the (Radiation Protection Manager) who shall meet or exceed the qualifications of Regulatory Guide 1.8, September 1975.

\subsection{TRAINING}

6.4.1 A retraining and replacement training program for the unit staff shall be maintained under the direction of the (position title) and shall meet or exceed the requirements and recommendations of Section 5.5 of ANSI N18.1-1971 and Appendix "A" of 10 CFR Part 55.

6.4.2 A training program for the Fire Brigade shall be maintained under the direction of the (position title) and shall meet or exceed the requirements of Section 27 of the NFPA Code-1975, except for Fire Brigade training sessions which shall be held at least once per 92 days.

\subsection{REVIEW AND AUDIT}

The method by which independent review and audit of facility operations is accomplished may take one of several forms. The licensee may either assign this function to an organizational unit separate and independent from the group having responsibility for unit operation or may utilize a standing committee composed of individuals from within and outside the licensee's organization.

Irrespective of the method used, the licensee shall specify the details of each functional element provided for the independent review and audit process as illustrated in the following example specifications.

\subsubsection{UNIT REVIEW GROUP (URG)}

FUNCTION

6.5.1.1 The (Unit Review Group) shall function to advise the (Plant Superintendent) on all matters related to nuclear safety. 


\section{COMPOSITION}

\subsubsection{The (Unit Review Group) shall be composed of the:}
Chairman:
Member:
Member:
Member:
Member:
Member:
Member:

\section{ALTERNATES}

6.5.1.3 All alternate members shall be appointed in writing by the (URG) Chairman to serve on a temporary basis; however, no more than two alternates shall participate as voting members in (URG) activities at any one time.

\section{MEETING FREQUENCY}

6.5.1.4 The (URG) shall meet at least once per calendar month and as convened by the (URG) Chairman or his designated alternate.

\section{QUORUM}

6.5.1.5 The minimum quorum of the (URG) necessary for the performance of the (URG) responsibility and authority provisions of these technical specifications shall consist of the Chairman or his designated alternate and four members including alternates.

\section{RESPONSIBILITIES}

6.5.1.6 The (Unit Review Group) shall be responsible for:

a. Review of 1) all procedures required by Specification 6.8 and changes thereto, 2) any other proposed procedures or changes thereto as determined by the ( $P$ lant Superintendent) to affect nuclear safety.

b. Review of all proposed tests and experiments that affect nuclear safety.

c. Review of all proposed changes to Appendix "A" Technical Specifications.

d. Review of all proposed changes or modifications to unit systems or equipment that affect nuclear safety. 
e. Investigation of all violations of the Technical Specifications inciuding the preparation and forwarding of reports covering evaluation and recommendations to prevent recurrence to the (Superintendent of Power Plants) and to the (Company Nuclear Review and Audit Group).

f. Review of events requiring 24 hour written notification to the Commission.

g. Review of unit operations to detect potential nuclear safety hazards.

h. Performance of special reviews, investigations or analyses and reports thereon as requested by the (Plant Superintendent) or the (Company Nuclear Review and Audit Group).

i. Review of the Security Plan and implementing procedures and shall submit recommended changes to the (Company Nuclear Review and Audit Group).

j. Review of the Emergency Plan and implementing procedures and shall submit recommended changes to the (Company Nuclear Review and Audit Group).

\section{AUTHORITY}

6.5.1.7 The (Unit Review Group) shall:

a. Recommend in writing to the (Plant Superintendent) approval or disapproval of items considered under 6.5.1.6(a) through (d) above.

b. Render determinations in writing with regard to whether or not each item considered under 6.5.1.6(a) through (e) above constitutes an unreviewed safety question.

c. Provide written notification within 24 hours to the (Superintendent of Power Plants) and the (Company Nuclear Review and Audit Group) of disagreement between the (URG) and the (Plant Superintendent); however, the (Plant Superintendent) shall have responsibility for resolution of such disagreements pursuant to 6.1 .1 above.

\section{RECORDS}

6.5.1.8 The (Unit Review Group) shall maintain written minutes of each (URG) meeting that, at a minimum, document the results of all (URG) activities performed under the responsibility and authority provisions of these technical specifications. Copies shall be provided to the (Superintendent of Power Plants) and the (Company Nuclear Review and Audit Group). 


\subsubsection{COMPANY NUCLEAR REVIEW AND AUDIT GROUP (CNRAG)}

FUNCTION

6.5.2.1 The (Company Nuclear Review and Audit Group) shall function to provide independent review and audit of designated activities in the areas of:

a. nuclear power plant operations

b. nuclear engineering

c. chemistry and radiochemistry

d. metallurgy

e. instrumentation and control

f. radiological safety

g. mechanical and electrical engineering

h. quality assurance practices

i. (other appropriate fields associated with the unique characteristics of the nuclear power plant)

\section{COMPOSITION}

\subsubsection{The (CNRAG) shall be composed of the:}

$\begin{array}{ll}\text { Director: } & \text { (Position Title) } \\ \text { Member: } & \text { (Position Title) } \\ \text { Member: } & \text { (Position Title) } \\ \text { Member: } & \text { (Position Title) } \\ \text { Member: } & \text { (Position Title) }\end{array}$

\section{ALTERNATES}

6.5.2.3 All alternate members shall be appointed in writing by the (CNRAG) Director to serve on a temporary basis; however, no more than two alternates shall participate as voting members in (CNRAG) activities at any one time.

\section{CONSULTANTS}

6.5.2.4 Consultants shall be utilized as determined by the (CNRAG) Director to provide expert advice to the (CNRAG). 


\section{MEETING FREQUENCY}

6.5.2.5 The (CNRAG) shall meet at least once per calendar quarter during the initial year of unit operation following fuel loading and at least once per -iv months thereafter.

\section{CQUORUM}

6.5.2.6 The minimum quorum of the (CNRAG) necessary for the performance of the (CNRAG) review and audit functions of these technical specifications shall consist of the Director or his designated alternate and (at least 4 CNRAG) members including alternates. No more than a minority of the quorum shall ha:e line responsibility for operation of the unit.

\section{REVIEW}

55.27 The (CNRAG) shall review:

a. The safety evaluations for 1) changes to procedures, equipment or systems and 2) tests or experiments completed under the provision of Section 50.59, 10 CFR, to verify that such actions did not constitute an unreviewed safety question.

b. Proposed changes to procedures, equipment or systems which involve an unreviewed safety question as defined in Section 50.59, 10 CFR.

c. Proposed tests or experiments which involve an unreviewed safety question as defined in Section 50.59, 10 CFR.

d. Proposed changes to Technical Specifications or this Operating License.

e. Violations of codes, regulations, orders, Technical Specifications, license requirements, or of internal procedures or instructions having nuclear safety significance.

f. Significant operating abnormalities or deviations from normal and expected performance of unit equipment that affect nuclear safety.

g. Events requiring 24 hour written notification to the Commission.

h. All recognized indications of an unanticipated deficiency in some aspect of design or operation of structures, systems, or components that could affect nuclear safety.

i. Reports and meetings minutes of the (Unit Review Group). 
AUDITS

6.5.2.8 Audits of unit activities shall be performed under the cognizance of the (CNRAG). These audits shall encompass:

a. The conformance of unit operation to provisions contained within the Technical Specifications and applicable license conditions at least once per 12 months.

b. The performance, training and qualifications of the entire unit staff at least once per 12 months.

c. The results of actions taken to correct deficiencies occurring in unit equipment, structures, systems or method of operation that affect nuclear safety at least once per 6 months.

d. The performance of activities required by the Operational Quality Assurance Program to meet the criteria of Appendix "B", 10 CFR 50, at least once per 24 months.

e. The Emergency Plan and implementing procedures at least once per 24 months.

f. The Security Plan and implementing procedures at least once per 24 months.

g. Any other area of unit operation considered appropriate by the (CNRAG) or the (Vice President Operations).

h. The Fire Protection Program and implementing procedures at least once per 24 months.

i. An independent fire protection and loss prevention inspection and audit shall be performed annually utilizing either qualified offsite licensee personnel or an outside fire protection firm.

j. An inspection and audit of the fire protection and loss prevention program shall be performed by an outside qualified fire consultant at intervals no greater than 3 years.

\section{AUTHORITY}

6.5.2.9 The (CNRAG) shall report to and advise the (Vice President 0perations) on those areas of responsibility specified in Sections 6.5.2.7 and 6.5.2.8. 
RECORDS

6.5.2.10 Records of (CNRAG) activities shall be prepared, approved and distributed as indicated below:

a. Minutes of each (CNRAG) meeting shall be prepared, approved and forwarded to the (Vice President-Operations) within 14 days following each meeting.

b. Reports of reviews encompassed by Section 6.5.2.7 above, shall be prepared, approved and forwarded to the (Vice President-Operations) within 14 days following completion of the review.

c. Audit reports encompassed by Section 6.5 .2 .8 above, shall be forwarded to the (Vice President-Operations) and to the management positions responsible for the areas audited within 30 days after completion of the audit by the auditing organization.

\subsection{REPORTABLE OCCURRENCE ACTION}

6.6.1 The following actions shall be taken for REPORTABLE OCCURRENCES:

a. The Commission shall be notified and/or a report submitted pursuant to the requirements of Specification 6.9 .

b. EACh REPORTABLE OCCURRENCE requiring 24 hour notification to the Commission shall be reviewed by the (URG) and submitted to the (CNRAG) and the (Superintendent of Power Plants).

\subsection{SAFETY LIMIT VIOLATION}

6.7.1 The following actions shall be taken in the event a Safety Limit is violated:

a. The unit shall be placed in at least HOT STANDBY within one hour.

b. The Safety Limit violation shall be reported to the Commission, the (Superintendent of Power Plants) and to the (CNRAG) within 24 hours.

c. A Safety Limit Violation Report shall be prepared. The report shall be reviewed by the (URG). This report shall describe (1) applicable circumstances preceding the violation, (2) effects of the violation upon facility components, systems or structures, and (3) corrective action taken to prevent recurrence.

d. The Safety Limit Violation Report shall be submitted to the Commission, the (CNRAG) and the (Superintendent of Power Plants) within 14 days of the violation. 


\subsection{PROCEDURES}

6.8. 1 Written procedures shall be established, implemented and maintained covering the activities referenced below:

a. The applicable procedures recommended in Appendix "A" of Regulatory Guide 1.33, Revision 2, February 1978.

b. Refueling operations.

c. Surveillance and test activities of safety related equipment.

d. Security Plan implementation.

e. Emergency Plan implementation.

f. Fire Protection Program implementation.

6.8.2 Each procedure of 6.8 .1 above, and changes thereto, shall be reviewed by the (URG) and approved by the (Plant Superintendent) prior to implementation and reviewed periodically as set forth in administrative procedures.

\subsubsection{Temporary changes to procedures of 6.8 .1 above may be made provided:}

a. The intent of the original procedure is not altered.

b. The change is approved by two members of the plant management staff, at least one of whom holds a Senior Reactor Operator's License on the unit affected.

c. The change is documented, reviewed by the (URG) and approved by the (Plant Superintendent) within 14 days of implementation.

\subsection{REPORTING REQUIREMENTS}

\section{ROUTINE REPORTS AND REPORTABLE OCCURRENCES}

6.9.1 In addition to the applicable reporting requirements of Title 10 , Code of Federal Regulations, the following reports shall be submitted to the Director of the Regional Office of Inspection and Enforcement unless otherwise noted.

\section{STARTUP REPORT}

6.9.1.1 A summary report of plant startup and power escalation testing shall be submitted following (1) receipt of an operating license, (2) amendment to the license involving a planned increase in power level, (3) installation of fue? that has a different design or has been manufactured by a different fue? supplier, and (4) modifications that may have significantly altered the nuclear, thermal, or hydrautic performance of the plant. 
6.9.1.2 The startup report shall address each of the tests identified in the FSAR and shall include a description of the measured values of the operating conditions or characteristics obtained during the test program and a comparison of these values with design predictions and specifications. Any corrective actions that were required to obtain satisfactory operation shall also be described. Any additional specific details required in license conditions based on other commitments shall be included in this report.

6.9.1.3 Startup reports shall be submitted within (1) 90 days following completion of the startup test program, (2) 90 days following resumption or commencement of commercial power operation, or (3) 9 months following initial criticality, whichever is earliest. If the Startup Report does not cover all three events (i.e., initial criticality, completion of startup test program, and resumption or commencement of commercial operation) supplementary reports shall be submitted at least every three months until all three events have been completed.

\section{ANNUAL REPORTS-'}

6.9.1.4 Annual reports covering the activities of the unit as described below for the previous calendar year shall be submitted prior to March 1 of each year. The initial report shall be submitted prior to March 1 of the year following initial criticality.

\subsubsection{Reports required on an annual basis shall include:}

a. A tabulation on an annual basis of the number of station, utility, and other personnel (including contractors) receiving exposures greater than $100 \mathrm{mrem} / \mathrm{yr}$ and their associated manrem exposure according to work and job functions, $2 /$ e.g., reactor operations and surveillance, inservice inspection, routine maintenance, special maintenance (describe maintenance), waste processing, and refueling. The dose assignments to various duty functions may be estimated based on pocket dosimeter, TLD, or film badge measurements. Small exposures totalling less than 20 percent of the individual total dose need not be accounted for. In the aggregate, at least 80 percent of the total whole body dose received from external sources should be assigned to specific major work functions.

\footnotetext{
I/A single submittal may be made for a multiple unit station. The submittal should combine those sections that are common to all units at the station.

2/This tabulation supplements the requirẹments of $\$ 20.407$ of 10 CFR Part 20 .
} 
b. The results of the core barrel movement monitoring activities performed during the report period. (CE units only).

c. (Any other unit unique reports required on an annual basis.)

\section{MONTHLY OPERATING REPORT}

6.9.1.6 Routine reports of operating statistics and shutdown experience shall be submitted on a monthly basis to the Director, Office of Management and Program Analysis, U.S. Nuclear Regulatory Commission, Washington, D.C. 20555, with a copy to the Regional Office of Inspection and Enforcement, no later than the 15th of each month following the calendar month covered by the report.

\section{REPORTABLE OCCURRENCES}

\subsubsection{The REPORTABLE OCCURRENCES of Specifications 6.9.1.8 and 6.9.1.9} below, including corrective actions and measures to prevent recurrence, shall be reported to the NRC. Supplemental reports may be required to fully describe final resolution of occurrence. In case of corrected or supplemental reports, a licensee event report shall be completed and reference shall be made to the original report date.

\section{PROMPT NOTIFICATION WITH WRITTEN FOLLOWUP}

6.9.1.8 The types of events listed below shall be reported within 24 hours by telephone and confirmed by telegraph, mailgram, or facsimile transmission to the Director of the Regional Office, or his designate no later than the first working day following the event, with a written followup report within 14 days. The written followup report shall include, as a minimum, a completed copy of a licensee event report form. Information provided on the licensee event report form shall be supplemented, as needed, by additional narrative material to provide complete explanation of the circumstances surrounding the event.

a. Failure of the reactor protection system or other systems subject to limiting safety system settings to initiate the required protective function by the time a monitored parameter reaches the setpoint specified as the limiting safety system setting in the technical specifications or failure to complete the required protective function.

b. Operation of the unit or affected systems when any parameter or operation subject to a limiting condition for operation is less conservative than the least conservative aspect of the limiting condition for operation established in the technical specifications.

c. Abnormal degradation discovered in fuel cladding, reactor coolant pressure boundary, or primary containment. 
d. Reactivity anomalies involving disagreement with the predicted value of reactivity balance under steady state conditions during power operation greater than or equal to $1 \% \Delta \mathrm{k} / \mathrm{k}$; a calculated reactivity balance indicating a SHUTDOWN MARGIN less conservative than specified in the technical specifications; short-term reactivity increases that correspond to a reactor period of less than 5 seconds or, if subcritical, an unplanned reactivity insertion of more than $0.5 \%$ $\Delta k / k$; or occurrence of any unplanned criticality.

e. Failure or malfunction of one or more components which prevents or could prevent, by itself, the fulfillment of the functional requirements of system(s) used to cope with accidents analyzed in the SAR.

f. Personnel error or procedural inadequacy which prevents or could prevent, by itself, the fulfillment of the functional requirements of systems required to cope with accidents analyzed in the SAR.

g. Conditions arising from natural or man-made events that, as a direct result of the event require unit shutdown, operation of safety systems, or other protective measures required by technical specifications.

h. Errors discovered in the transient or accident analyses or in the methods used for such analyses as described in the safety analys is report or in the bases for the technical specifications that have or could have permitted reactor operation in a manner less conservative than assumed in the analyses.

i. Performance of structures, systems, or components that requires remedial action or corrective measures to prevent operation in a manner less conservative than assumed in the accident analyses in the safety analysis report or technical specifications bases; or discovery during unit life of conditions not specifically considered in the safety analysis report or technical specifications that require remedial action or corrective measures to prevent the existence or development of an unsafe condition.

\section{THIRTY DAY WRITTEN REPORTS}

6.9.1.9 The types of events listed below shall be the subject of written reports to the Director of the Regional Office within thirty days of occurrence of the event. The written report shall include, as a minimum, a completed copy of a licensee event report form. Information provided on the licensee event report form shall be supplemented, as needed, by additional narrative material to provide complete explanation of the circumstances surrounding the event. 
a. Reactor protection system or engineered safety feature instrument settings which are found to be less conservative than those established by the technical specifications but which do not prevent the fulfillment of the functional requirements of affected systems.

b. Conditions leading to operation in a degraded mode permitted by a limiting condition for operation or plant shutdown required by a limiting condition for operation.

c. Observed inadequacies in the implementation of administrative or procedural controls which threaten to cause reduction of degree of redundancy provided in reactor protection systems or engineered safety feature systems.

d. Abnormal degradation of systems other than those specified in 6.9.1.8. C above designed to contain radioactive material resulting from the fission process.

SPECIAL REPORTS

Special reports may be required covering inspections, test and maintenance activities. These special reports are determined on an individual basis for each unit and their preparation and submittal are designated in the Technical Specifications.

6.9.2 Special reports shall be submitted to the Director of the Office of Inspection and Enforcement Regional office within the time period specified for each report.

\subsection{RECORD RETENTION}

In addition to the applicable record retention requirements of Title 10, Code of Federal Regulations, the following records shall be retained for at least the minimum period indicated.

6.10.1 The following records shall be retained for at least five years:

a. Records and logs of unit operation covering time interval at each power level.

b. Records and logs of principal maintenance activities, inspections, repair and replacement of principal items of equipment related to nuclear safety.

c. AlI REPORTABLE OCCURRENCES submitted to the Commission. 
d. Records of surveillance activities, inspections and calibrations required by these Technical Specifications.

e. Records of changes made to the procedures required by Specification 6.8.1.

f. Records of radioactive shipments.

g. Records of sealed source and fission detector leak tests and results.

h. Records of annual physical inventory of all sealed source material of record.

6.10.2 The following records shall be retained for the duration of the Unit Operating License:

a. Records and drawing changes reflecting unit design modifications made to systems and equipment described in the Final Safety Analysis Report.

b. Records of new and irradiated fuel inventory, fuel transfers and assembly burnup histories.

c. Records of radiation exposure for all individuals entering radiation control areas.

d. Records of gaseous and liquid radioactive material released to the environs.

e. Records of transient or operational cycles for those unit components identified in Table 5.7-1.

f. Records of reactor tests and experiments.

g. Records of training and qualification for current members of the unit staff.

h. Records of in-service inspections performed pursuant to these Technical Specifications.

i. Records of Quality Assurance activities required by the QA Manual.

j. Records of reviews performed for changes made to procedures or equipment or reviews of tests and experiments pursuant to 10 CFR 50.59 .

k. Records of meetings of the (URG) and the (CNRAG). 


\subsection{RADIATION PROTECTION PROGRAM}

Procedures for personnel radiation protection shall be prepared consistent with the requirements of 10 CFR Part 20 and shall be approved, maintained and adhered to for all operations involving personnel radiation exposure.

\subsection{HIGH RADIATION AREA (OPTIONAL)}

6.12.1 In lieu of the "control device" or "alarm signal" required by paragraph 20.203 (c)(2) of 10 CFR 20, each high radiation area in which the intensity of radiation is greater than $100 \mathrm{mrem} / \mathrm{hr}$ but 1 ess than $1000 \mathrm{mrem} / \mathrm{hr}$ shall be barricaded and conspicuously posted as a high radiation area and entrance thereto shall be controlled by requiring issuance of a Radiation Work Permit*. Any individual or group of individuals permitted to enter such areas shall be provided with or accompanied by one or more of the following:

a. A radiation monitoring device which continuously indicates the radiation dose rate in the area.

b. A radiation monitoring device which continuously integrates the radiation dose rate in the area and alarms when a preset integrated dose is received. Entry into such areas with this monitoring device may be made after the dose rate level in the area has been established and personnel have been made knowledgeable of them.

c. An individual qualified in radiation protection procedures who is equipped with a radiation dose rate monitoring device. This individual shall be responsible for providing positive control over the activities within the area and shall perform periodic radiation surveillance at the frequency specified by the facility Health Physicist in the Radiation Work Permit.

6.12.2 The requirements of 6.12 .1 , above, shall also apply to each high radiation area in which the intensity of radiation is greater than 1000 $\mathrm{mrem} / \mathrm{hr}$. In addition, locked doors shall be provided to prevent unauthorized entry into such areas and the keys shall be maintained under the administrative control of the Shift Foreman on duty and/or the Plant Health Physicist.

\footnotetext{
₹Health Physics personnel or personnel escorted by Health Physics personnel shall be exempt from the RWP issuance requirement during the performance of their assigned radiation protection duties, provided they comply with approved radiation protection procedures for entry into high radiation areas.
} 


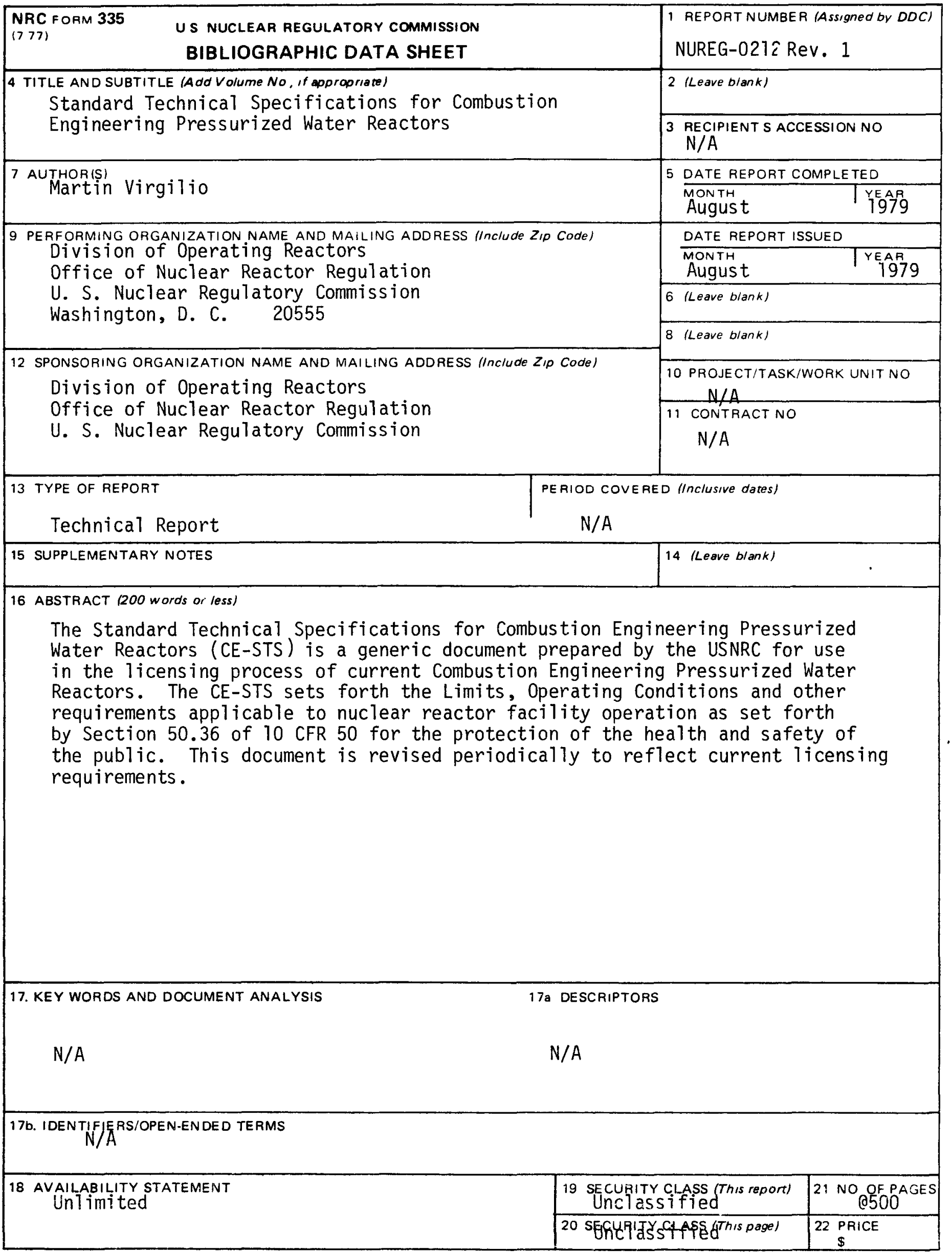


UNITED STATES

NUCLEAA REGULATORY COMMISSION WASHINGTON, D.C. 20555

OFFICIAL BUSINESS

PENALTY FOR PRIVATE USE, $\$ 300$

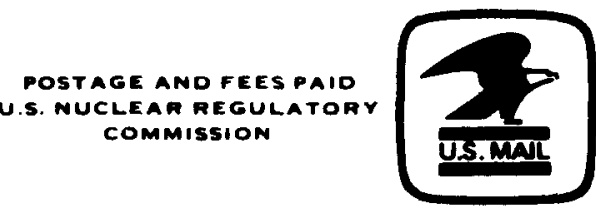

